Pontifícia $U_{\text {niversidade }}$ Católica $_{\text {Do Rio de Janelro }}$

Daise Gomes da Costa

A Pedagogia de YHWH e o seu povo diante
da Lei: Uma análise de Dt 31,9-13.

DISSERTAÇÃO DE MESTRADO

DEPARTAMENTO DE TEOLOGIA

Programa de Pós-Graduação em Teologia

Rio de Janeiro

Julho de 2021 


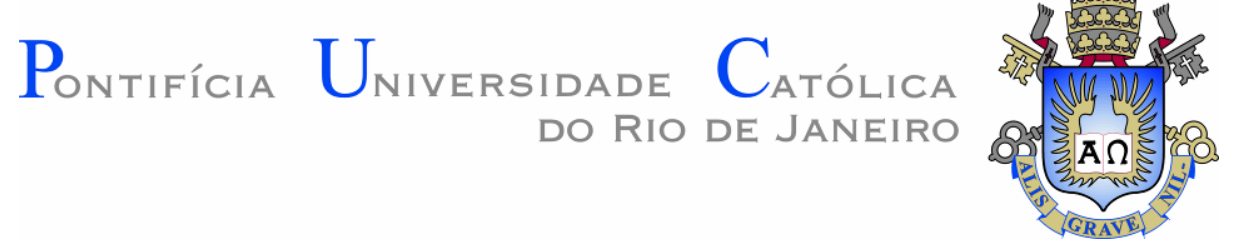

Daise Gomes da Costa

\section{A Pedagogia de YHWH e o seu povo diante da Lei: Uma análise de Dt 31,9-13.}

Dissertação de Mestrado

Dissertação apresentada como requisito parcial para obtenção do grau de Mestre pelo Programa de Pós-graduação em Teologia do Departamento de Teologia da PUC-Rio.

Orientador: Prof. Leonardo Agostini Fernandes 


\section{Pontifícia Universidade Católica

\section{Daise Gomes da Costa}

\section{A Pedagogia de YHWH e o seu povo diante da Lei: Uma análise de Dt 31,9-13.}

Dissertação apresentada como requisito parcial para obtenção do grau de Mestre pelo Programa de Pós-Graduação em Teologia do Departamento de Teologia do Centro de Teologia e Ciências Humanas da PUC-Rio. Aprovada pela Comissão Examinadora abaixo.

Prof. Leonardo Agostini Fernandes Orientador

Departamento de Teologia - PUC-Rio

Prof. Waldecir Gonzaga

Departamento de Teologia - PUC-Rio

Prof. Luiz Alexandre Solano Rossi Departamento de Teologia - PUC-PR 
Todos os direitos reservados. É proibida a reprodução total ou parcial do trabalho sem autorização da universidade, da autora e do orientador.

\section{Daise Gomes da Costa}

Graduou-se em Pedagogia pela Fundação Educacional Unificada Campograndense (FEUC) e em Teologia pela Pontifícia Universidade Católica do Rio de Janeiro (PUCRio). É diretora do Centro Educacional de Santíssimo. Atua como professora-evangelizadora nas Escolas de Fé e Catequese Mater Ecclesiae e Luz e Vida da Arquidiocese de São Sebastião do Rio de Janeiro.

Ficha Catalográfica

Costa, Daise Gomes da

A pedagogia de $\mathrm{YHWH}$ e o seu povo diante da Lei: Uma análise de Dt 31,9-13 / Daise Gomes da Costa; orientador: Leonardo Agostini Fernandes. - 2021.

144 f.; $30 \mathrm{~cm}$

Dissertação (mestrado)-Pontifícia Universidade Católica do Rio de Janeiro, Departamento de Teologia, 2021.

Inclui bibliografia

1. Teologia - Teses. 2. Livro da Lei. 3. Aliança. 4. Israel. 5. Obediência. 6. Terra Prometida. I. Fernandes, Leonardo Agostini. II. Pontifícia Universidade Católica do Rio de Janeiro. Departamento de Teologia. III. Título. 
Ao meu esposo, José Teodoro, pelo apoio, incentivo e compreensão. 


\section{Agradecimentos}

A YHWH, o Deus de amor e misericórdia, que nos cumula de toda graça necessária, para vivermos conforme a sua vontade. Agradeço por estar presente em minha vida conduzindo meus passos e me inspirando a prosseguir em frente com força, fé, coragem e persistência.

Ao meu orientador, Prof. Dr. Pe. Leonardo Agostini Fernandes, por toda atenção e disponibilidade oferecida, por tudo que me proporcionou aprender e pela compreensão nos momentos delicados que passei. Meu agradecimento será eterno, que YHWH seja a sua fortaleza e nunca lhe falte as suas copiosas bênçãos.

Ao CNPq e à PUC-Rio, pelos auxílios concedidos, sem os quais este trabalho não poderia ter sido realizado.

Ao Departamento de Teologia que, me admitindo em seu corpo discente, deu-me a oportunidade de prosseguir meus estudos na pós-graduação, ajudando na minha formação acadêmica e espiritual. A minha sincera estima e agradecimento.

Ao meu esposo, José Teodoro da Costa Neto, que de forma especial e carinhosa me transmitia força, sempre me apoiando nos momentos de dificuldades e me estimulando a não desistir; e aos nossos filhos: Rodrigo Gomes da Costa, Daniel Gomes da Costa e Marianne Gomes da Costa, também nossa nora, Carla Rafaela de Souza Silva e nossa neta, Laura Silva da Costa, pela compreensão nos momentos de ausência e apoio nos momentos difíceis. Bênçãos abundantes de Deus.

Aos meus pais, Armando Gomes (in memoriam) e Georgina Lopes Gomes, que me educaram com disciplina e amor, preocuparam-se com a minha formação e esforçaram-se em fazer o melhor. Muita paz e bênçãos de Deus. 
Aos meus familiares, em especial agradeço à minha irmã Denise Lopes Gomes, que cuidou de nossa mãe para que eu prosseguisse com a pesquisa. Muitas bênçãos de Deus em sua vida.

Aos demais familiares e amigos, que acompanharam toda a minha trajetória e torceram por mim, agradeço por fazerem parte da minha história. Muitas bênçãos de Deus.

Às irmãs da Casa da Criança (Botafogo): Ir. Suzana Maria de Lima, Ir. Maria Mônica Velozo Camelo e Ir. Vera Lúcia Bezerra da Costa, que me apoiaram e me acolheram todas as vezes que necessitei me hospedar próximo da PUC. Agradeço de coração tudo que fizeram por mim. Em especial agradeço a Ir. Suzana pelo tempo que estudamos juntas nos preparando para prova de seleção do mestrado. Foi um tempo muito bom, jamais esquecerei a sua ajuda. Que Deus retribua em dobro tudo que fizeram por mim, multiplicando as bênçãos na vida de vocês e de toda a Congregação ao qual pertencem.

Ao Colégio Imaculado Coração de Maria e às Irmãs Servas Missionárias do Espírito Santo, toda a minha gratidão pelos 15 anos que fiz parte do corpo docente desta Instituição, por tudo que me proporcionaram e pela experiência profissional adquirida. Que nunca falte as bênçãos de Deus para esta casa. Ali fiz muitas amizades, saúdo em especial, minha grande e eterna amiga, Therezinha de Jesus Moraes (in memoriam), Deus sempre foi o seu porto seguro.

Ao Centro Educacional de Santíssimo (CES), um sonho que Deus tornou realidade, agradeço a todos (as) que ali trabalham pela dedicação e compromisso com a Instituição diante da minha necessária ausência, destaco o empenho das coordenadoras pedagógicas, Joice da Cruz Melo e Patricia Marcondes Garcêz, a atuação de vocês foi muito importante. Que Deus esteja sempre presente em nossa Escola dando todo suporte necessário para prosseguirmos em nossa missão e que as suas bênçãos sejam abundantes em nossas vidas.

Ao Pe. Rafael José da Silva Xavier, pároco de Sant’Ana, Campo Grande, paróquia ao qual pertenço, agradeço as suas orações em meu favor e as palavras motivadoras para eu seguir em frente. Que Deus o abençoe muito. 
Ao Pe. Aurelino Pinto da Silva (in memoriam), pelo que representou em minha formação espiritual e acadêmica. Foi ele que me incentivou a dar os primeiros passos nos estudos teológicos, encaminhando-me para a Escola Mater Ecclesiae no ano de 1985. Tivemos uma convivência muito próxima, foram 19 anos na Paróquia Coração Eucarístico de Jesus, que ele esteja desfrutando da glória eterna junto ao Pai.

Ao Pe. João Paulo Pinto dos Santos Batista, pela amizade e pelo carinho com minha família, que Deus esteja cuidando de ti e nunca lhe falte a sua bênção.

À Escola de Fé e Catequese Mater Ecclesiae e Luz e Vida da Arquidiocese de São Sebastião do Rio de Janeiro, na pessoa do vice-diretor, Pe. Fábio Silveira Siqueira o meu profundo carinho pelo incentivo e pela amizade. À secretária Ir. Maria da Salete C.N.S.B., que foi minha professora no Mater Ecclesiae e se tornou uma amiga, a mais sincera gratidão e reconhecimento. Deus a abençoe sempre.

Ao Instituto Superior de Ciências Religiosas, na pessoa de seus diretores: Dom Joseph Romer e Prof ${ }^{a}$ Maria de Lourdes Corrêa Lima o meu agradecimento especial por tudo que me proporcionaram durante os três anos que ali estudei.

Aos professores do PPG-Teologia e aos funcionários do Departamento de Teologia da PUC-Rio, pela permanente disposição, cordialidade e excelência no trabalho.

Aos amigos de turma: Bianca, Diego, Leniziane, Rafael e Ygor, pela amizade, carinho e o laço fraterno que se formou entre nós. Deus seja sempre louvado em nossas vidas.

À professora e amiga Rosana Alves Faria pela revisão do texto. Deus a abençoe.

A todos os que me acompanharam com seu apoio, carinho e orações, as bênçãos de Deus.

O presente trabalho foi realizado com apoio da Coordenação de Aperfeiçoamento de Pessoal de Nível Superior - Brasil (CAPES) - Código de Financiamento 001. 


\section{Resumo}

Costa, Daise Gomes; Fernandes, Leonardo Agostini. A Pedagogia de YHWH e o seu povo diante da Lei: Uma análise de Dt 31,9-13. Rio de Janeiro, 2021. 144p. Dissertação de Mestrado - Departamento de Teologia, Pontifícia Universidade Católica do Rio de Janeiro.

A presente dissertação analisa Dt 31,9-13, reconhecendo as estratégias usadas por YHWH para conduzir o seu povo no conhecimento da verdade e na prática da justiça. O livro da Lei, que foi "escrito" por Moisés conforme a ordem de YHWH, é um elemento singular. Esse material pedagógico foi entregue aos sacerdotes, filhos de Levi, e aos anciãos. Josué, futuro sucessor de Moisés, é, no contexto, uma figura em destaque. O livro da Lei atesta a aliança estabelecida entre YHWH, o Deus único, e Israel, o povo eleito. Se o primeiro ponto de contato de YHWH e Israel teve como propósito libertá-los e salvá-los da escravidão do Egito; o segundo ponto indica o projeto pedagógico de YHWH: deseja que Israel seja um povo livre e fiel, e se torne um paradigma para as demais nações, ou seja, quer que o seu plano salvífico se estenda à toda humanidade. A terra prometida, dom e herança, após o tempo do deserto será o grande "banco de prova”. Moisés foi o escolhido para a sublime missão de conduzir o povo. A palavra de ordem é: obediência; que deve se traduzir em amor e fidelidade ao Deus da Aliança. Sendo obediente, o povo alcançará as bênçãos, ao passo que, desobediente, atrairá as maldições: perda da terra e exílio. A abordagem de Dt 31,9-13 foi feita através dos passos do Método Histórico-Crítico. Contudo, a pesquisa pela abordagem sincrônica aplicada no comentário, também procurou compreender, pela lógica do conjunto, a pedagogia de YHWH frente ao povo que elegeu como sua particular propriedade. Uma história com seus altos e baixos, marcada pela fidelidade de YHWH e pelas infidelidades do povo sempre chamado a viver de acordo com a aliança. Bênçãos e maldições marcam essa história que continua válida e sendo escrita na mente e no coração de cada fiel. A preocupação com a formação das futuras gerações é o dado fundamental, a fim de que a obediência da fé seja o caminho de conformação com a vontade salvífica de YHWH.

\section{Palavras-chave}

Livro da Lei; Aliança; Israel; Obediência; Terra prometida. 


\section{Abstract}

Costa, Daise Gomes; Fernandes, Leonardo Agostini. The pedagogy of YHWH and his people in front of the Law: An analyzes of Deut 31,9-13. Rio de Janeiro, 2021. 144p. Dissertação de Mestrado - Departamento de Teologia, Pontifícia Universidade Católica do Rio de Janeiro.

This dissertation analyzes Deut 31,9-13, recognizing the strategies used by YHWH to conduct his people by the knowledge of truth and the practice of justice. The Book of the King, that was written by Moses as it was ordered by YHWH, is a singular element. This pedagogic material was delivered to the Priests, Levi's sons and to the ancients. Josue, Moses's future successor, is, in this context, a highlighted figure. The book of the law attests the alliance established between YHWH, the one and only God, and Israel, the elected people. If the first point for the contact between YHWH and Israel had the purpose of freeing and saving them from the slavery of Egpty; The second point indicates the pedagogic project of YHWH: wishes israel's people to be free and faithful, and become a paradigm for other nations, that is, he wants his saving plan to extend to all humanity. The promised land, gift and heritage, after the time of the desert there will be the great "trial". Moses was chosen for the sublime mission of conducting the people. The word of order is: obedience; that must translate into love and fidelity to the alliance's God. By being obedient, his people will reach their blessings, otherwise, by being disobedient, they will attract curses, lose their lands and will be exiled. The approach of the Dt 31,9-13 was done following the Historical and critical method, however, the research through the synchronic approach applied in the commentary, also sought to understand, through the logic, the pedagogy of YHWH in front of the people that he elected as private property. A history with its highs and lows, marked by the fidelity of YHWH and infidelities of his people always called to live according to the alliance. Blessings and curses mark this history that keeps going and being written in the mind and heart of each believer. The concern with the development of the future generations is the fundamental fact, in order for the obedience of the faith to be the way of conformation with the saving will of YHWH.

\section{Keywords}

Book of the Law; Alliance; Israel; Obedience; Promised Land. 


\section{Sumário}

1. Introdução 15

2. Preliminares hermenêuticas 18

2.1. Um olhar geral para o livro de Deuteronômio 18

2.2. Autoria, datação e composição 23

2.3. A figura do grande líder: Moisés 31

2.4. De Moisés a Josué, uma pedagogia de liderança 38

3. Análise exegética de Dt 31,9-13 44

3.1. Tradução segmentada 44

3.2. Notas de crítica textual 45

3.3. Delimitação, unidade e organização 49

3.3.1. Quanto à delimitação 49

3.3.2. Quanto à unidade 55

3.3.3. Quanto à organização 61

3.4. Estrutura e gênero literário 63

3.4.1. Quanto à estrutura 63

3.4.2. Quanto ao gênero literário 69

4. Comentário de Dt 31,9-13 71

4.1. Seção A - O livro da Lei: escrito para ser transmitido (v. 9) 71

4.1.1. Moisés escreve o que YHWH ordena (v. 9a) 71

4.1.2. Entrega aos sacerdotes (v. 9bc) 74

$\begin{array}{ll}\text { 4.1.3. E aos anciãos (v. 9d) } & 87\end{array}$

4.2. Seção B - Moisés ambienta a execução da ordem (vv. 10-11) 89

4.2.1. A ordem é dada aos destinatários (v. 10ab) 89

4.2.2. O tempo e ocasião para a leitura da Lei (v. 10c) 91

4.2.3. A escolha do lugar (v. 11abc) 95 
4.2.4. A Lei deverá ser lida para todo o Israel (v. 11de) 99

4.3. Seção C - Ordem abrangente dada por Moisés (vv. 12-13) 105

4.3.1. Congregar Israel com uma finalidade específica (v. 12ab) 105

4.3.2. Para ouvir a Lei e aprender a temer a YHWH (v. 12 cde) 108

4.3.3. Para observar a Lei (v. 12f) 112

4.3.4. Para colocar em prática todas as palavras da Lei (v. 12g) 114

4.3.5. Para que as futuras gerações conheçam a Lei (v. 13abc) 115

4.3.6. Para praticar a Lei todos os dias da vida sobre a terra (v. 13d) 118

4.3.7. Para tomar posse da terra prometida (v. 13ef) 120

5. Considerações finais $\quad 124$

$\begin{array}{ll}\text { 6. Anexos } & 128\end{array}$

7. Referências bibliográficas 134 


\section{Lista de siglas e abreviações}

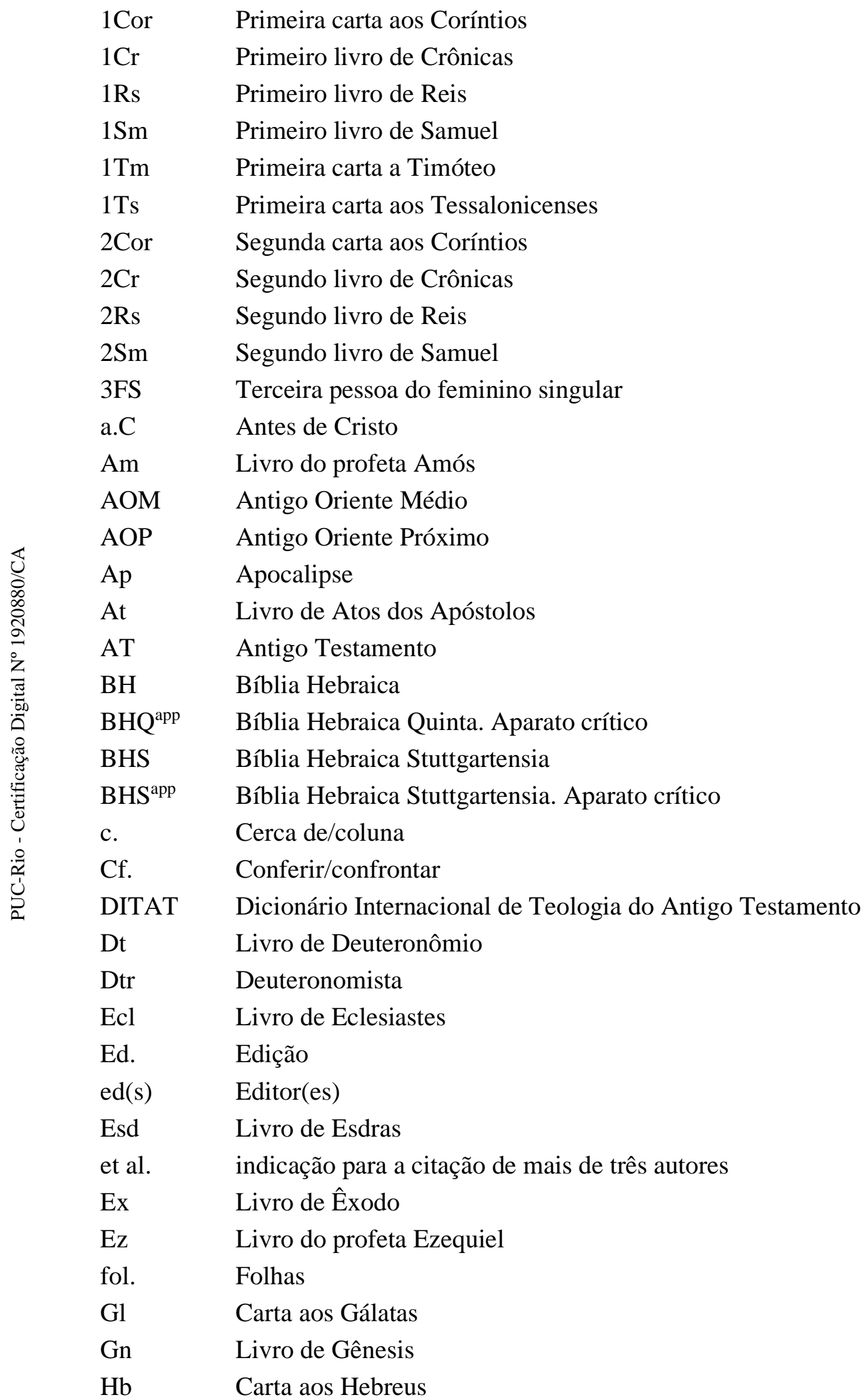




\begin{tabular}{|c|c|}
\hline Impr. & Impressão \\
\hline Is & Livro do profeta Isaías \\
\hline $\mathrm{Jn}$ & Livro do profeta Jonas \\
\hline Jo & Evangelho segundo João \\
\hline Jó & Livro de Jó \\
\hline $\mathrm{Jr}$ & Livro do profeta Jeremias \\
\hline Js & Livro de Josué \\
\hline $\mathrm{Jz}$ & Livro de Juízes \\
\hline $\mathrm{Lc}$ & Evangelho segundo Lucas \\
\hline $\mathrm{Lv}$ & Livro de Levítico \\
\hline LXX & Septuaginta \\
\hline M & Metros \\
\hline Mc & Evangelho segundo Marcos \\
\hline Ml & Livro do profeta Malaquias \\
\hline Mt & Evangelho segundo Mateus \\
\hline NDITEAT & $\begin{array}{l}\text { Novo Dicionário Internacional de Teologia e Exegese do Antigo } \\
\text { Testamento }\end{array}$ \\
\hline $\mathrm{Ne}$ & Livro de Neemias \\
\hline $\mathrm{Nm}$ & Livro de Números \\
\hline NT & Novo Testamento \\
\hline $\operatorname{Org}(\mathrm{s})$ & Organizador(es) \\
\hline Os & Livro do profeta Oséias \\
\hline p. & Página/páginas \\
\hline $\mathrm{Pv}$ & Livro de Provérbios \\
\hline Red. & Redator \\
\hline Ro & Carta aos Romanos \\
\hline Rt & Livro de Rute \\
\hline Séc. & Século \\
\hline Sécs. & Séculos \\
\hline S1 & Livro de Salmos \\
\hline s.n. & Editora não informada \\
\hline $\mathrm{TM}^{\mathrm{L}}$ & Texto Massorético Leningradense \\
\hline $\operatorname{Trad}(\mathrm{s})$ & Tradutor(es) \\
\hline v. & Versículo \\
\hline vv. & Versículos \\
\hline ver. & Versão verificada \\
\hline $\operatorname{vol}(\mathrm{s})$ & Volume/volumes \\
\hline $\mathrm{Zc}$ & Livro do profeta Zacarias \\
\hline
\end{tabular}


"Olhai as aves do céu: não semeiam, nem colhem, nem ajuntam em celeiros. E, no entanto, vosso Pai Celeste as alimenta. Observai os lírios do campo, como crescem e não trabalham e nem fiam. E, no entanto, eu vos asseguro que nem Salomão, em toda a sua glória, se vestiu como um deles. Vosso Pai Celeste sabe que tendes necessidade de todas essas coisas. Buscai, em primeiro lugar, seu Reino e sua justiça, e todas essas coisas vos serão acrescentadas"

(Mt 6,26.28-29.32-33). 


\section{1 \\ Introdução}

O livro de Deuteronômio fecha o corpus da Torá. É composto por 34 capítulos que podem ser divididos em quatro partes, usando como critério de divisão os quatro grandes discursos de Moisés, no seu último dia de vida: "se trata do dia mais longo de toda a permanência no deserto". ${ }^{1}$

Moisés discursa ao povo nas estepes de Moab e lança, no seu presente histórico, um olhar para o passado (rever as experiências) em função do futuro (aplicar as experiências à vida prática). A renovação da aliança é a base das relações entre YHWH e Israel.

No centro do estudo realizado está o movimento dessas relações, com base em Dt 31,9-13. Foca-se, principalmente, na história e na caminhada desse povo, pois essa marcha, rumo à terra de Canaã, apresenta momentos de grande fé e de fidelidade a YHWH, mas também momentos de esquecimento, revolta e infidelidade por parte do povo. Subjaz a isso uma percepção: "O ser humano é uma criatura que depende da obediência e foi criado para ela". ${ }^{2}$ Para tanto, alguns elementos, que iluminam o campo da pesquisa foram enfatizados e a obediência é o ponto alto e que norteia o sentido buscado nesse estudo, confirmando que "Deus é o Deus da segunda chance. Um dos maiores temas do livro de Deuteronômio o é que a bondade de Deus foi demonstrada vez após vez, apesar das falhas e rebeliões do povo".3

O estudo sobre Dt 31,9-13 evidencia um projeto pedagógico de YHWH na formação de uma nação que dispôs e separou para si, evidentemente, com o propósito de atingir os demais povos e nações. Israel deverá ser sinal para todos, servirá como exemplo e paradigma de uma nação cuja fé está centrada em um único Deus, pelo qual a justiça e a paz são o reflexo do grande seu amor, pois escolheu um povo simples e humilde e, através deste, quer mostrar para toda a humanidade a sua força e o seu poder salvífico. O mundo temeu o povo de Israel, porque esse povo tinha um Deus superior a todas as divindades cultuadas na época. Sendo assim, o Deus de Israel se tornou conhecido, pois a sua imagem foi

\footnotetext{
${ }^{1}$ SKA, J. L., "I nostri padri ci hanno raccontato", p. 24.

${ }^{2}$ BRUEGGMANN, W., Teologia do Antigo Testamento, p. 598.

${ }^{3}$ CHAMPLIN, R. N., O Antigo Testamento Interpretado: versículo por versículo, p. 15.
} 
refletida através de Israel, principalmente pela postura de seus líderes. Então, todas as nações puderam conhecer o Deus forte e soberano do povo de Israel.

Por sua pedagogia, YHWH se fez conhecido a todos os povos através de um grupo de pessoas - que eram grandes em número (quantidade), mas pequenos em importância (escravos no Egito) - e transformou toda essa gente em uma nação organizada e estruturada em função da Torá (teocracia) mas também respeitada e temida diante de seu Deus. Israel foi feito sinal de salvação para os demais povos. A sua frente estava YHWH, o grande Pedagogo que conduziu essa história através do seu servo, Moisés, profeta inigualável (Dt 34,10-12).

A vida se faz de escolhas. Pode-se vagar pelo deserto da incredulidade, do egoísmo e da desobediência ou entrar na terra prometida, assumir batalhas e experimentar provações, confiando que YHWH requer fé e obediência. ${ }^{4}$

O presente trabalho divide-se em sete partes: uma introdução, três capítulos, que correspondem ao desenvolvimento do conteúdo pesquisado, as considerações finais, os anexos e as referências bibliográficas.

No primeiro capítulo são apresentadas as preliminares hermenêuticas; um parecer geral sobre as questões básicas que envolvem o livro de Deuteronômio, como suporte para se compreender os capítulos subsequentes. Foram destacados, de forma geral, alguns pontos importantes da obra, como: título, dinâmica do livro, forma literária, estilo, temas principais, objetivos teológicos e pedagógicos. A atenção dispensada à autoria, datação e composição, apresentou os problemas relativos e algumas hipóteses que ainda estão longe de oferecer uma palavra final. Esse capítulo é finalizado com uma abordagem sobre a figura do grande líder Moisés, o escolhido por YHWH e na sequência lança-se um olhar para Josué, seu sucessor, demonstrando o valor dos ensinamentos da Torá e a sua pedagogia que fizeram dele um grande líder, começou como "auxiliar de Moisés" (Js 1,1) e terminou sua carreira como "servo de YHWH" (Js 24,29), mesmo título pelo qual o próprio YHWH havia designado Moisés (Js 1,2).

O segundo capítulo está dedicado ao estudo exegético de Dt 31,9-13. Foram seguidos os passos do Método Histórico-Crítico: a tradução segmentada do texto, seguida pelas notas de crítica textual, que verificou as variantes do texto com o intuito de estabelecer o texto mais próximo do original. Em seguida, foi feita a

\footnotetext{
${ }^{4}$ WIERSBE, W. W., Comentário Bíblico Expositivo, p. 489.
} 
análise criteriosa do texto, a partir da sua delimitação, unidade, organização, estrutura e gênero literário, observando que foi possível visualizar a estrutura de forma simétrica.

No terceiro capítulo apresenta-se o comentário exegético de Dt 31,9-13. Seguiu-se a estrutura adotada evidenciando os aspectos sintáticos, semânticos, teológicos, pelos quais foi possível compreender melhor a mensagem e os seus particulares pedagógicos. Nesse sentido, buscou-se comprovar a validade do conhecimento de YHWH e da sua vontade serem capazes de determinar o comportamento a ser pautado na verdade, no bem e na prática da justiça.

Visto que o comentário foi feito a partir da forma final e canônica do texto, segundo a sua divisão em seções, considerando-se o contexto próximo e remoto, o uso da abordagem sincrônica favoreceu a percepção e a compreensão da mensagem teológica de Dt 31,9-13.

Nas considerações finais, buscou-se apresentar a síntese das principais etapas realizadas e abordadas, fundamentadas nas referências bibliográficas que foram utilizadas para a presente dissertação. Além disso, três anexos permitem a visualização de certas informações que foram aludidas nas notas de rodapé. 


\section{2. \\ Preliminares hermenêuticas}

\section{1. Um olhar geral para o livro de Deuteronômio}

Há quem considere o livro de Deuteronômio um dos mais importantes atribuindo-lhe a imagem da "batida do coração do AT". em Qumran a maior quantidade de cópias se tratava do livro de Deuteronômio (15 cópias), ao passo que dos demais livros o máximo de cópias encontradas foram 5 , o que denota um grande interesse por esta obra. ${ }^{6}$

Para o cristianismo, não é diferente, o livro de Deuteronômio está entre os três livros mais citados no NT, ao lado de Isaías e do Saltério, ${ }^{7}$ inclusive o próprio Jesus citou esse livro diversas vezes. ${ }^{8}$ A relevância desse livro o torna a base para se estabelecer uma interface entre a teologia do AT e a do NT. ${ }^{9}$

Na Bíblia Hebraica, os títulos dos livros são dados a partir das primeiras palavras que abrem cada obra. No caso de Deuteronômio, o livro começa da

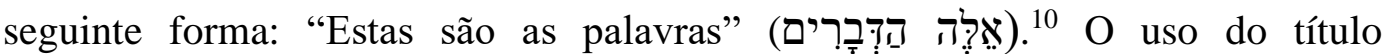
"Deuteronômio" se deu em virtude da tradução da LXX e provavelmente, advém

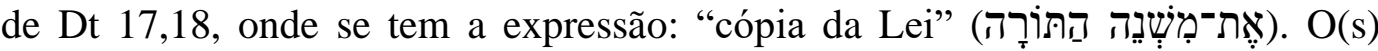
tradutor(es) do livro de Deuteronômio, que traduziram do hebraico para o grego,

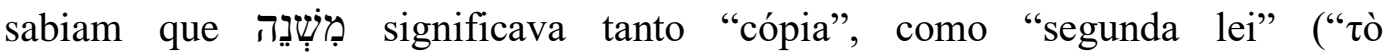

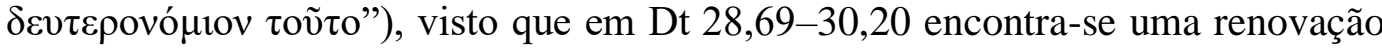
da aliança, que havia sido selada com os libertos no Horeb/Sinai, ${ }^{11}$ com a geração

\footnotetext{
${ }^{5}$ HAYS, J. D.; DUVALL, J. S., Manual Bíblico Ilustrado Vida, p. 108.

${ }^{6}$ STORNIOLO, I., O Livro do Deuteronômio, p. 7.

${ }^{7}$ Segundo HOFF, P., (O Pentateuco, p. 256): "O NT refere-se a Deuteronômio e cita-o mais de oitenta vezes. Parece que era um dos livros prediletos de Jesus, pois ele o citava amiúde". Segundo PAPOLA, G., (Deuteronomio, p. 12): "No NT, Deuteronômio é o quinto livro em ordem ao número de citações após Salmos, Isaías, Gênesis e Êxodo". Sobre citações e alusões do livro de Deuteronômio no NT, conferir anexo 3.

${ }^{8}$ Mt 4,4.7; 5,21.27.38.43; 15,4; 19,18-19; 22,37; Mc 7,10; 10,19; 12,29-31; 13,27; Lc 4,4.8.12; 10,$27 ; 18,20$.

${ }^{9}$ STORNIOLO, I., O Livro do Deuteronômio, p. 7.

${ }^{10}$ CRAIGIE, P. C., Comentários do Antigo Testamento - Deuteronômio, p. 17.

${ }^{11}$ Segundo YAMAUCHI, E., (זרֶ. In: HARRIS, R. L.; ARCHER, G. L.; WALTKE, B. K. DITAT, p. 525). "Nome alternativo para o monte Sinai, derivado de חָרב . Significa "região desolada". Ocorre 17 vezes, das quais nove em Deuteronômio. A hipótese documentária sugere que este nome que designa a montanha de Deus é característico de D e E (Êx 3,1; 17,6; 33,6), ao passo que Sinai é usado nas seções de J e P (veja, porém, Dt 33,2)".
} 


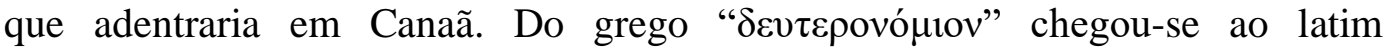
“deuteronomium", e assim, passou para as demais traduções em vernáculo. No seu conjunto, o livro de Deuteronômio contém memórias sobre o tempo do deserto, instruções e exortações sobre a futura conquista da terra de Canaã e sobre o relacionamento de Israel com os seus habitantes. ${ }^{12}$

O fato de o livro conter um Código legislativo (Dt 12-26*), ${ }^{13}$ não significa que o(s) autor(es) quisesse(m) que o livro servisse como um manual de leis, para aqueles que iriam administrar essas leis, como: sacerdotes, anciãos, juízes e reis. Apesar de no interno do livro de Deuteronômio se encontrar um bloco de leis, classificadas tanto pelo caráter apodítico como casuístico, ${ }^{14}$ de qualquer forma, estão associadas a elas vários discursos exortativos que se entrelaçam mostrando uma característica peculiar dentro do livro: é uma lei pregada que vincula as partes da aliança. ${ }^{15}$

A legislação contida no livro de Deuteronômio expressa a vontade de YHWH que deve ser observada e obedecida. O livro, porém, não trata de um código judicial em si, mas coloca as leis em função da fé como obediência incondicional do povo a YHWH. As leis atestam ensinamentos que sugerem um estilo de vida diferente, que permite receber e desfrutar das bênçãos de YHWH. ${ }^{16}$

O maior propósito de Moisés, grande interlocutor protagonista no livro, foi o de persuadir o povo à uma entrega total de vida voltada para YHWH. Isto, diretamente, significa amá-lo de todo coração, de toda a alma e com toda a força (Dt 6,5). Assim, Israel deve adorar um único Deus e isso servirá de testemunho

\footnotetext{
${ }^{12}$ WIERSBE, W. W., Comentário Bíblico Expositivo, p. 490.

${ }^{13}$ O livro de Deuteronômio surgiu, em grande medida, como nova edição do livro da aliança, sob o critério da reivindicação de centralização do culto (SCHMID, K., História da Literatura do Antigo Testamento, p. 134).

${ }^{14}$ Existiam classes de leis: As leis de caráter casuístico seguem a forma do "se" e expõem o caso com precisão. Tratam dos casos litigiosos da vida diária da comunidade. Já as leis de caráter apodítico são formuladas em declarações breves, suscintas, geralmente, introduzidas por imperativos afirmativos ou negativos, como os Dez Mandamentos. São sentenças que expressam uma ordem ou proibição: "Tu farás" ou "não farás" (RENDTORFF, R., A formação do Antigo Testamento, p. 11-12).

${ }^{15}$ Segundo BROWN, R., (Entendendo o Antigo Testamento, p. 37): "Por todo o Oriente Médio, sempre que dois reis queriam fazer algum tipo de pacto ou acordo, um tipo de tratado especial era redigido. Esses tratados seguiam modelos claramente definidos e sua estrutura era algo assim: começavam com uma declaração do autor do tratado, depois algum detalhe histórico era fornecido, seguido pelas estipulações e exigências. O tratado era concluído, dando-se detalhes do combinado sobre a sucessão (caso morresse o autor) e um trecho final mencionava uma série de bênçãos (se o tratado fosse cumprido) e maldição (caso fosse quebrado)".

${ }^{16}$ THOMPSON, J. A., Deuteronômio Introdução e Comentário, p. 13.
} 
para as outras nações. ${ }^{17}$ Desta forma, se verifica que o princípio básico do livro é histórico-salvífico, pois se caracteriza pela eleição de um povo que, liberto da escravidão foi chamado a ser sinal de salvação, não só para si, mas para todos. ${ }^{18}$

Desta forma, se pode entender que o título dado na Bíblia Hebraica, "Estas são as palavras", é um convite a adentrar no seu conteúdo e a descobrir o seu propósito: o registro das palavras proferidas por Moisés ao "novo Israel", ${ }^{19}$ visando o grande projeto de YHWH a ser ensinado às futuras gerações.

Com estilo exortativo o orador usa palavras destinadas a captar a atenção e a mover a congregação ao compromisso e obediência ao Deus da aliança. ${ }^{20}$ Como se pode verificar, o livro está redigido na forma de discursos de Moisés que se deram "do outro lado do Jordão, na terra de Moab" (Nm 36,13; Dt 1,1-5). ${ }^{21}$

Analisando a forma literária empregada no livro de Deuteronômio, percebese, do ponto de vista pedagógico e teológico, as intenções que se desdobram nos livros que se seguem (Js-Rs). De qualquer forma, o livro de Deuteronômio, finalizando a Torá, mostra pela ação de Moisés, mestre exemplar, como proceder na formação e na execução das leis. ${ }^{22}$

Quanto aos discursos de Moisés, que compõem a obra final e canônica do livro de Deuteronômio, podem ser divididos em dois momentos:

O bloco Dt 1-11 seria um olhar para trás; foi, eventualmente, o momento utilizado por Moisés para fazer memória do passado, ouvir e recordar os feitos de YHWH, tudo o que operou extraordinariamente na vida do povo que libertou da escravidão do Egito. Inclusive lembrou dos patriarcas e da primeira aliança. ${ }^{23}$

\footnotetext{
${ }^{17}$ CHAMPLIN, R. N., O Antigo Testamento Interpretado: Versículo por versículo, p. 5.

${ }^{18}$ SCHMIDT, W. H., Introdução ao Antigo Testamento, p.127-133.

${ }^{19}$ Nessa dissertação, Israel será usado como o povo destinatário dos últimos discursos de Moisés no livro de Deuteronômio. Trata-se de um "novo Israel", nascido durante o tempo do deserto. Apenas Josué e Caleb, pertencentes à geração dos libertos, entrarão em Canaã com suas famílias (Nm 14,38)

${ }^{20}$ CRAIGIE, P. C., Comentários do Antigo Testamento - Deuteronômio, p. 17.

${ }^{21}$ GRADL, F.; STENDEBACH, F. J., Israel e seu Deus, p. 39.

${ }^{22}$ LAMADRID, A. G., História, Narrativa, Apocalíptica, p. 42. O livro de Deuteronômio pode ser lido tanto no contexto do Pentateuco, fechando a Torá, quanto na sequência dos livros históricos, abrindo a programática historiografia Deuteronomista (ROSE, M., Deuteronômio. In: RÖMER, T.; MACCHI, J. D.; NIHAN, C. Antigo Testamento, p. 260).

${ }^{23}$ Os três patriarcas - Abraão, Isaac e Jacó - são mencionados juntos por sete vezes em Dt 1,8; 6,$10 ; 9,5.27 ; 29,13 ; 30,20 ; 34,4$. A ênfase sobre a terra prometida é constante, repete-se por quase duzentas vezes nesse livro. "De acordo com o pacto Abraâmico, a terra prometida fazia parte da herança dada por YHWH. Essa promessa fora transmitida aos outros patriarcas - Isaac e Jacó - e agora estava sendo conferida aos Israelitas de várias gerações posteriores" (CHAMPLIN, R. N., O Antigo Testamento Interpretado: Versículo por versículo, p. 9).
} 
O bloco Dt 12-34 pode ser considerado um olhar para frente, pois Moisés após fazer a ampla retrospectiva, considerando pontos importantes do passado, lembra que é hora de colocar em prática o que foi vivenciado e aprendido. Além das pregações e ensinamentos administrados por Moisés durante os quarenta anos de permanência no deserto, Moisés, antes de morrer, também "deixa por escrito" o livro da Lei. ${ }^{24}$

Em síntese, o livro de Deuteronômio, em sua forma geral, retrata uma série de discursos onde o protagonista é sempre YHWH ou Moisés. Esses discursos culminam no relato da morte de Moisés no monte Nebo, quarenta anos depois da saída do Egito.

A moldura narrativa apresenta quatro blocos de discursos que representam, de certo modo, o "testamento" de Moisés. ${ }^{25}$ Esses discursos soam como uma longa despedida do grande líder, com instruções pertinentes para que o seu povo prossiga a jornada, sob o comando de Josué, seu sucessor, - e finalize o objetivo do grande projeto pedagógico formulado por YHWH: a entrada e a conquista de Canaã, cumprimento da promessa feita aos patriarcas. ${ }^{26}$

Outrossim, ao se observar a didática aplicada por YHWH no livro de Deuteronômio, a fim de apresentar uma teologia que está elaborada numa linha pedagógica, nota-se um vivo interesse por orientar o povo escolhido, conduzindoo a compreender esse projeto pedagógico que YHWH determinou em favor de Israel, e, a partir deste, como um projeto a ser estendido para todas as nações. Por isso, o livro visa a unidade e conduz a cinco pontos cruciais para se atingir a qualificação esperada por YHWH: um Deus, um povo, uma Lei, uma terra e um santuário.

\footnotetext{
${ }^{24}$ Noth observou que "em todos os momentos importantes no decurso da história, Dtr apresenta a personagem mais importante pronunciando um discurso voltado para frente e para trás, numa tentativa de interpretar o curso dos acontecimentos" (RÖMER, T., A chamada história deuteronomista, p. 31).

25 "O livro do Deuteronômio emprega uma série de rodeios típicos, sem paralelos nos outros quatro livros do Pentateuco. Assim, as expressões 'amar a YHWH' (Dt 6,5; 10,12; 11,1.13.22; $13,4 ; 19,9 ; 30,6.16 .20)$, 'com todo o teu coração e com toda a alma' $(4,29 ; 6,5 ; 10,12 ; 11,13 ; 13,4$; $26,16 ; 30,2.6 .10)$, 'fazer o que é reto e bom aos olhos de YHWH' $(6,18 ; 12,25.28 ; 13,19 ; 21,9)$, 'o lugar que YHWH escolherá para fazer morar/colocar ali o seu nome' $(12,5.11 .21 ; 14,23.24$; $16,2.6 .11 ; 26,1)$ etc. Esses e muitos outros rodeios, juntamente com a tonalidade parenética, dão um distintivo especial ao livro, conhecido como "linguagem e estilo deuteronomistas"” (LÓPEZ, F. G., O Pentateuco, p. 27).

${ }^{26}$ ZENGER, E. et. al., Introdução ao Antigo Testamento, p. 48.
} 
A unidade, assim desdobrada, mostra que os temas não são estanques, mas devem, ainda que individualmente, serem entrelaçados, pois estão vinculados à mesma trama, em que os fatores pedagógicos e teológicos irão dar margem a outros temas, como: libertação, comunidade, eleição, aliança, bênção, maldição. Tudo isso forma o grande conjunto de uma obra tão especial como o livro de Deuteronômio. $^{27}$

Um olhar para o livro de Deuteronômio, como pedagogia de libertação, salvação e justiça, tem como finalidade principal elevar um povo simples e sofredor à condição de nação eleita ${ }^{28}$ e agraciada por YHWH em função da aliança que foi estabelecida entre ambos a partir do monte Horeb/Sinai. Esta aliança tem Moisés como o principal intermediário entre a palavra de YHWH e Israel, cujo objetivo principal é estabelecer Israel como nação teocrática, ${ }^{29}$ tendo como pátria a terra prometida e como contrato a legislação que foi mediada por Moisés. ${ }^{30}$

Por isso, uma das preocupações do livro é ligar as leis deuteronômicas (Dt 12-26*) ao decálogo (Dt 5,1-21), pois as duas foram concebidas sob a autoridade de Moisés, único e especial intermediário, "a quem YHWH conhecia face a face" (Dt 34,10). O propósito principal de YHWH é, sem dúvida, o de atingir Israel de forma eficaz para que através do seu coração e da sua inteligência, formados por uma justa legislação, se comovam, se convençam e se deixem influenciar pela proposta de YHWH. Assim, através do seu conhecimento e dos seus sentimentos, possa aderir totalmente à dinâmica de vida que YHWH É e propõe para Israel. ${ }^{31}$

O livro de Deuteronômio é um tesouro precioso de conceitos teológicos que influenciou os profetas responsáveis pela "História Deuteronômica", os profetas

\footnotetext{
${ }^{27}$ LÓPEZ, F. G., El Deuteronomio - una ley predicada, p. 6.

${ }^{28}$ A singularidade de Israel também é apresentada em uma perspectiva de caráter social. O povo de Israel é de fato essencialmente um povo de irmãos, e a fraternidade não se limita aos estreitos laços de sangue, mas pertence ao povo de YHWH (PAPOLA, G., Deuteronomio, p. 22).

${ }^{29} \mathrm{Na}$ aliança estabelecida no monte Horeb/Sinai, com a entrega da Lei a Moisés, compreende-se que o plano de YHWH envolvia um reino teocrático, no qual o próprio Deus seria o Rei de Israel (LINDSAY, G., Moisés, o legislador, p. 25).

${ }^{30}$ HARRINGTON, W. J., Chave para a Bíblia, p. 218.

${ }^{31}$ No que se refere ao Código Deuteronômico, se pode refletir que ele tenha a intenção de fazer uma reflexão acerca do Decálogo e do Código da Aliança (Ex 20,22-23,19), na forma de uma edição atualizada. A explicação está no fato que o autor do livro de Deuteronômio viveu muito tempo depois do "tempo da narração", ou seja, numa época em que os acontecimentos já haviam ocorrido, portanto, o pano de fundo social, político e religioso que fazia parte do contexto ao qual o livro foi escrito era: infidelidade à aliança, opressão política, exploração econômica, idolatria, problemas sociais, lutas e outros (STORNIOLO, I., O Livro do Deuteronômio, p. 9-12).
} 
anteriores, bem como os posteriores. Não é de se admirar que muitos estudiosos se interessam em adentrar no conteúdo desse livro, tamanha é a sua importância dentro da Sagrada Escritura. ${ }^{32}$ A vida religiosa de judeus e cristãos, influenciados pela proposta de justiça social denotam que seus ideais teológicos e pedagógicos continuam válidos e ajudam a orientar o ser humano na sua busca pela verdadeira felicidade.

\section{2.}

\section{Autoria, datação e composição}

Por longos séculos, a autoria de todo o Pentateuco ${ }^{33}$ foi atribuída a Moisés. ${ }^{34}$ Judeus e cristãos, seguindo a tradição, associaram a Moisés a autoria dos cinco primeiros livros do AT. Com a evolução da pesquisa, porém, diversos pontos foram questionados e comprovaram que Moisés não poderia ser o único autor do Pentateuco. O ponto de partida para o questionamento foi Dt 34, que narra a morte e o sepultamento de Moisés. Obviamente, não seria possível Moisés narrar a sua própria morte. ${ }^{35}$

A partir de então, a pesquisa cresceu e muitos outros pontos de divergências foram apontados no corpus do Pentateuco, como por exemplo, a questão de quantos dias durou o dilúvio: quarenta $(\mathrm{Gn} 8,6)$ ou cento e cinquenta dias ( $\mathrm{Gn}$ 7,24)? As duplicatas: dois relatos da vocação de Moisés (Ex 3,1-4,17; 6,2-7,7); duas versões do Decálogo (Ex 20,2-17 e Dt 5,6-21). ${ }^{36}$

Isso levou a crer que Moisés não pode ser o único autor da obra. No entanto, não se alcançou ainda um consenso sobre quem seria(am) o(s) autor(es). Várias possibilidades foram levantadas e estão relacionadas a épocas diferentes, mas em

\footnotetext{
${ }^{32}$ LASOR, W. S.; HUBBARD, D. A.; BUSH, F. W., Introdução ao Antigo Testamento, p. 129.

33 'O Pentateuco pode ser entendido como uma 'biografia de Moisés', sendo que os livros do Êxodo ao Deuteronômio cobrem sua vida desde o nascimento (Ex 2) até à morte, enquanto o livro de Gênesis constitui uma espécie de prólogo à história de Moisés e à história do Êxodo" (RÖMER, T., A chamada história deuteronomista, p. 9).

${ }^{34}$ Até o início do Séc. XX se pensava que todo o conjunto do Pentateuco havia sido escrito por Moisés, mas com a evolução das pesquisas chegou-se ao entendimento que o Pentateuco é resultado de muitas mãos, de vários locais e épocas diferentes (LUZA, N., Uma Introdução ao Pentateuco, p. 7).

${ }^{35}$ LÓPEZ, F. G., El Deuteronomio - una ley predicada, p. 7-8.

${ }^{36}$ Segundo PURY, A., (O Pentateuco em Questão, p. 21): "Uma maneira bastante óbvia de tentar resolver o problema das contradições, dos dobletes e das diferenças de estilo foi distribuir as passagens em conflito por fontes, documentos ou camadas redacionais diferentes".
} 
si, o problema não foi solucionado. Os estudos avançam, mas a questão continua aberta, de modo que a questão da autoria se liga à da datação e da composição.

$\mathrm{O}(\mathrm{s})$ autor(es) do livro de Deuteronômio sabia(m) que se dirigia(m) a uma sociedade dividida por classes sociais. Mas o projeto pedagógico inspirado por YHWH era para uma sociedade de irmãos, sem divisões entre classes. Seu objetivo era formar um único povo socialmente vinculado à fraternidade. Portanto, subjaz à autoria do livro de Deuteronômio uma reflexão teológica sobre uma base sociológica. Enfim, um grande projeto de reforma religiosa, caracterizado pelos dois reis ótimos, Ezequias $^{37}$ e Josias,${ }^{38}$ com implicações políticas e sociais, que culminariam numa mudança sociorreligiosa condizente com a vontade de YHWH. $^{39}$

Quanto à datação, os problemas não são menores, oscilam desde o próprio tempo de Moisés, aproximadamente 1230, até 400 a.C. Sobre tal ponto, ainda não se chegou a um acordo condizente. Algumas hipóteses foram levantadas:

Samuel e Davi (sécs. XI-IX a.C.): Acredita-se que o livro de Deuteronômio possa ter sido compilado na época do sacerdote e último juiz Samuel, e se estendido provavelmente até o reinado de Davi; supõem-se, ainda, que possa ter chegado até os primeiros anos após a morte de Salomão. ${ }^{40}$

Profetas do séc. VIII a.C.: Nesse caso, há uma ligação entre as passagens bíblicas que se relacionam e que podem ter sido influenciadas por elementos contidos no livro de Deuteronômio em sua redação. Por exemplo a lei dos marcos (Dt 19,14) parece ser conhecida por Oséias (Os 5,10); sobre a medida padrão (Dt 25,13-16) parece ser conhecida por Amós (Am 8,5) e, também, por Miquéias (Mq 6,10-11); sobre a devolução do dízimo (Dt 14,28) parece ser conhecido por Amós (Am 4,4); e sobre a autoridade do sacerdócio que parece ter sido conhecida por

\footnotetext{
${ }^{37}$ Ezequias aproveitou a ocasião da morte do rei Sargon, em 705 a.C. e as sucessivas revoltas que ocorreram em relação ao novo rei Senaquerib, para se livrar da soberania assíria, e assim, alargar as fronteiras do reino de Judá (2Rs 18,8; $2 \mathrm{Cr} 30,1 \mathrm{~s})$. Começou a empreender reformas religiosas importantes de cunho político e religioso (2Rs 18,22). Infelizmente, esse renascimento durou pouco, pois Senaquerib retomou o domínio da região no ano de 701 a.C. e restabeleceu a soberania assíria. (LÓPEZ, F. G., El Deuteronomio - una ley predicada, p. 14).

38 "No séc. VII a.C. aparece o Deuteronômio primitivo (12-26*), descoberto no tempo de Josias (622/1 a.C) no Templo de Jerusalém, que inclui normas e instituições dos camponeses do Norte, e mais tarde foi completado, formando o atual texto de Dt 1-28" (LUZA, N., Uma Introdução ao Pentateuco. p. 10).

39 “'̀ diferença da tradição sacerdotal, o Deuteronômio não faz distinção entre tribos e famílias, nem entre classes sociais. Ao contrário, seu ideal é fazer com que todos, do rei ao último escravo, sejam irmãos" (LÓPEZ, F. G., El Deuteronomio - una ley predicada, p. 11-12).

${ }^{40}$ THOMPSON, J. A., Deuteronômio Introdução e Comentário, p. 53.
} 
Oséias (Os 4,4-10). Contudo, esses paralelos não provam necessariamente que os profetas dessa época tiveram contato com o livro de Deuteronômio. ${ }^{41}$

Profetas do séc. VII a.C.: Segundo Ernest Wilson Nicholson (1938-2013) o livro se originou no reino do Norte a partir de um corpo profético estabelecido. Mas devido a queda de Samaria esse grupo se desloca para Judá. Para ele a composição se deu durante o período do reinado de Manassés. Um período sombrio para a fé de Israel, mas em contrapartida, vem em seguida um período de esperanças com o reinado de Ezequias. É nesse período que começa a ser traçado um projeto de reforma tendo Jerusalém como sede política e religiosa. ${ }^{42}$

Sacerdotes levitas do séc. VII a.C.: O livro pode ter tido sua origem no reino do Norte, onde os levitas haviam preservado antigas leis e tradições da aliança. Para Gerald Von Rad (1901-1971), os sacerdotes levitas eram os porta-vozes do movimento de reforma do culto e foram os verdadeiros autores do livro de Deuteronômio. George Ernest Wright (1909-1974) aceitou o ponto de vista de Von Rad, concordou com o fato de que foram os sacerdotes levitas do Norte que guardaram as tradições mosaicas, mas discordou que tenham sido eles os autores. $^{43}$

Escribas entre os sécs. VIII-VII a.C.: Uma possibilidade de autoria se relaciona também com os escribas que atuaram no período que vai de Ezequias a Josias. Presume-se que os autores do livro de Deuteronômio tenham sido membros do círculo literário presente na corte, especificamente, escribas. ${ }^{44}$

Desta forma, se pode falar de atividade literária e história política, pois o livro encontrado no Templo exerceu certa influência sobre a política do rei (2Rs 22,3-23,27). E, provavelmente, acontece nesse período uma nova edição da obra em vista de enquadrá-la nas experiências concretas dessa época. ${ }^{45}$

\footnotetext{
${ }^{41}$ John William Colenso (1814-1883) debruçou-se a fazer um exame detalhado do vocabulário usado no livro de Deuteronômio e destacou a diferença deste vocabulário em relação aos quatro primeiros livros do Pentateuco e, também, assinalou a sua proximidade com a linguagem dos profetas anteriores (RÖMER, T., A chamada história deuteronomista, p. 25; HAMILTON, V. P., Manual do Pentateuco, p. 427; THOMPSON, J. A., Deuteronômio Introdução e Comentário, p. 51).

${ }^{42}$ RÖMER, T., A chamada história deuteronomista, p.158.

${ }^{43}$ THOMPSON, J. A., Deuteronômio Introdução e Comentário, p. 59-60; HAMILTON, V. P. Manual do Pentateuco, p. 427.

${ }^{44}$ ZENGER, E. et. al., Introdução ao Antigo Testamento, p. 105.

${ }^{45}$ ROSE, M., Deuteronômio, in RÖMER, T.; MACCHI, J. D.; NIHAN, C. Antigo Testamento, p. 271.
} 
Sábios do séc. VII a.C.: Moshe Weinfeld (1925-2009), assegurou que o livro de Deuteronômio só poderia ser obra de sábios escribas. Importante destacar que no final do séc. VII a.C. e início do VI a.C., os sábios, profetas e sacerdotes agiam como grupos independentes, como demonstram os textos de $\mathrm{Jr} 18,18$ e Ez $7,26 .^{46}$

Corrente Sacerdotal dos sécs. VI-V a.C.: Para Gustav Hölscher (18771955), o livro de Deuteronômio foi escrito por sacerdotes por volta do ano 500 a.C., no pós-exílio. Partiu do princípio, que Ageu e Zacarias tiveram pouco contato com o livro de Deuteronômio, mas em contrapartida, encontrou muitos pontos de contato (referências ao livro de Deuteronômio) no livro de Malaquias. Para ele, o livro de Deuteronômio se tratava de um documento particular, voltado somente para o uso dos sacerdotes em Jerusalém. ${ }^{47}$ Os textos mais antigos teriam a ver com textos sacerdotais, que remontam ao período pós-exílico. ${ }^{48}$

Escola Deuteronomista do séc. VI-IV a.C.: A História Deuteronomista é concebida numa perspectiva exílica. Disto se deduz, que os deuteronomistas faziam parte do grupo levado para Babilônia na primeira deportação em 597 a.C. É provável que tenham levado rolos da biblioteca do Templo e os reescreveram na Babilônia. Para Noth o deuteronomista foi um historiador que usou tradições antigas, dando um novo arranjo, ou seja, atualizando-as. "A atitude do Dtr para com suas tradições é a de um 'corretor honesto"”. 49

Admitir a história Deuteronomista, considerando o livro de Deuteronômio, levaria a crer que o objetivo seria o de explicar tais desastres e narrar os acontecimentos desde a conquista da terra prometida até sua perda para Nabucodonosor, rei da Babilônia. Dt 29,21-30,14 seriam uma alusão "pósevento", justificando que tais fatos foram concretizados como Moisés havia previsto. Israel não observou a Lei e se manteve constantemente na infidelidade a aliança com YHWH. Desta forma, se pode dizer que o livro de Deuteronômio em

\footnotetext{
${ }^{46}$ Em Jr 8,8, se tem uma afirmação: "Como podeis dizer: 'Nós somos sábios e a lei de YHWH está conosco!'” Jeremias está exortando os sacerdotes e alerta que os sábios ficarão envergonhados, pois a corrupção e a injustiça haviam entrado e contaminado a classe sacerdotal (HAMILTON, V. P., Manual do Pentateuco, p. 428).

${ }^{47}$ THOMPSON, J. A., Deuteronômio Introdução e Comentário, p. 47-67.

${ }^{48}$ SKA, J. L., O Canteiro do Pentateuco, p. 17.

49 'Quando Noth criou a 'História Deuteronomista', ele não tinha dúvida nenhuma de que toda a obra era sobretudo uma reflexão sobre a derrota de Jerusalém e o 'exílio'. Desde, então, o exílio sempre desempenhou um papel central na interpretação da História Deuteronomista" (RÖMER, T., A chamada história deuteronomista, p. 32.112.162).
} 
uma primeira fase se tornou a base da história Deuteronomista que vai culminar no segundo livro de reis: Dt, Js, Jz, 1-2Sm, 1-2Rs. ${ }^{50}$

Esdras entre os séculos V-IV a.C.: Alguns estudiosos, portanto, asseguram que o autor da Torá teria sido Esdras, o escriba que retornou da Babilônia para reavivar a fé de Israel. Em seus estudos o francês Baruch Spinosa (1632-1677), já havia chegado a essa conclusão e declarara, sem negar que as partes atribuídas a Moisés poderiam ser de sua autoria e que a Torá foi escrita por Esdras. As pesquisas continuaram avançando com Andreas Masius (1514-1573) e Richard Simon (1638-1712) e até hoje ainda se defende essa ideia. Alguns textos importantes, que serviram de base para essa discussão, foram: Ne 8; 2Rs 22-23; Ex 24,3-8. ${ }^{51}$

Esdras é admitido como uma figura-chave da etapa decisiva de composição de Deuteronômio e de todo o Pentateuco. Sobretudo, porque ele era um comissário imperial no reino persa e sacerdote-escriba judeu. Por volta de 400 a.C. promulgou em Jerusalém um Código de leis que foi aprovado pelos persas, que constituiu o documento base da identidade judaica, um tipo de "autorização imperial". 52

Apesar de todo esse debate e diferentes posicionamentos, não há consenso entre os estudiosos, mas, de qualquer forma, tudo indica que uma parte do material do livro é de origem antiga, provavelmente do tempo de juízes, quando o sistema era ainda tribal, em forma ou regime de confederações. Quanto aos acréscimos, revisões e atualizações foram ocorrendo no decorrer do tempo, onde provavelmente passou por diversas mãos. ${ }^{53}$

É difícil elucidar quem ou quais círculos seriam os maiores responsáveis pelo processo de formação do livro de Deuteronômio ${ }^{54}$ e a sua ligação com a História Deuteronomista. Se pode atribuir a círculos distintos: 1) Aos círculos sacerdotais de levitas, dado o protagonismo dos levitas no livro de Deuteronômio

\footnotetext{
${ }^{50}$ Segundo AZCÁRATE, J. L. L., (Deuteronomio, p. 23-24): "Parece claro que as edições deuteronomísticas de Deuteronômio realizadas durante o exílio na Babilônia pretendem responder à questão de se a segunda geração do exílio retornará à terra ou deverá seguir pagando a culpa de seus pais, a primeira geração que morreu no exílio. De alguma forma, a nova aliança em Moab é a resposta e a nova aliança que também fez YHWH com a segunda geração".

${ }^{51}$ SKA, J. L., O Canteiro do Pentateuco, p. 185-187.

${ }^{52}$ ZENGER, E. et. al., Introdução ao Antigo Testamento, p. 51.

${ }^{53}$ THOMPSON, J. A., Deuteronômio Introdução e Comentário, p. 66.

${ }^{54}$ Verificar anexo 2.
} 
e a preocupação social que este demonstra por eles $;{ }^{55}$ 2) Aos círculos proféticos dos séc. VIII e VII a.C., dado alguns temas comuns, como o amor de YHWH por seu povo, a denúncia da infidelidade de Israel, a luta contra a idolatria, as evocações da tradição do êxodo, e a preocupação com a justiça social; ${ }^{56}$ 3) Aos círculos sapienciais, dadas algumas conexões com a literatura sapiencial.

Ao lado disso, também foi sugerida uma solução eclética, considerando que o livro de Deuteronômio tem sua origem no movimento Jerosolimitano, formado por grupos distintos, mas ao mesmo tempo superpostos que atuaram entre o reinado de Manassés e Josias (no período de sua menor idade). Um grupo formado por escribas, sacerdotes, sábios e aristocratas. Uma mescla das autoridades competentes e instruídas da época que poderiam, portanto, ter redigido o livro de Deuteronômio. ${ }^{57}$

O livro de Deuteronômio surgiu dos melhores esforços de diferentes pessoas, ou grupos, que se empenharam em interpretar e atualizar antigas tradições, e assim, manter viva a identidade de Israel e a sua relação com YHWH e a Lei. A palavra final ainda não foi dada e está longe de encontrar um ponto comum. Como se viu, inúmeras são as hipóteses para a autoria e não faltam estudos acerca do assunto, mas a dificuldade de se chegar a um consenso continua sendo um grande obstáculo.

No que se refere ao processo de composição do livro de Deuteronômio, três momentos cruciais da história de Israel, que envolvem o processo de elaboração do texto, podem ser destacados. O primeiro está localizado na segunda metade do séc. VIII a.C. no reino de Israel (Norte). O segundo período equivale ao séc. VII a.C. no reino de Judá (Sul). O terceiro período se encontra na primeira metade do séc. VI em Babilônia (cativeiro).

Com a descoberta do livro da Lei no Templo de Jerusalém (2Rs 22,8), se pode fazer referência ao ano de 622/1 a.C., como base de datação para tais

\footnotetext{
${ }^{55}$ Dt 12,12.18-19; 14,27.29; 16,11.14; 17,18; 18,1.6.7; 24,8; 26,1-13; 27,9.14; $31,25$.

56 "Vinculados ao pensamento ou teologia de profetas como Amós, Isaías, Miquéias, Oséias e, mais tarde, Jeremias, sendo difícil determinar se a influência primária procede do Deuteronômio para os profetas ou vice-versa. Basta dizer que a mesma matriz interpretativa era comum a ambos: lei e profecia" (AZCÁRATE, J. L. L., Deuteronomio, p. 25-26.).

57 "O recorrente 'temer a YHWH', embora não exclusivamente sapiencial, é um vocabulário relacionado; ver Dt 4,5-8, para círculos sapienciais de escribas, talvez geradores do desenvolvimento de Deuteronômio desde os tempos de Josias para os de Esdras" (AZCÁRATE, J. L. L., Deuteronomio, p. 25-26).
} 
eventos. Supõe-se, portanto, que nessa data o núcleo primitivo do livro de Deuteronômio já existisse (Dt $12-26^{*}$ ). ${ }^{58}$ Quanto as origens, provavelmente, o início do processo de composição se deu no reino do Norte, antes da queda de Samaria em 722/1 a.C. ${ }^{59}$ Esses escritos tiveram continuidade no reino do Sul, pois muitos israelitas migraram para Judá-Jerusalém, fugindo dos assírios. Quanto à sua conclusão, tudo indica, que tenha ocorrido no cativeiro da Babilônia, após a queda de Jerusalém em 587/6 a.C., prosseguindo, inclusive, ainda após o exílio. ${ }^{60}$

O livro de Deuteronômio passou por um longo e complexo processo de composição. ${ }^{61}$ Em seu conjunto se encontram redações Deuteronômicodeuteronomistas, ${ }^{62}$ que foram elaboradas, provavelmente, por anciãos/escribas de Jerusalém. Mas a obra apresenta também ecos das tradições de cunho Jahwista, Elohísta e Sacerdotal, principalmente no bloco de Dt 31-34. ${ }^{63}$

Dt 12-26* foi, provavelmente, elaborado a partir do Código da Aliança (Ex 20,22-23,19), começou a tomar sua forma talvez no tempo do rei Ezequias e ganhou novos contornos com Josias para fundamentar as suas reformas. ${ }^{64}$

Existiu, primeiramente, um material pré-deuteronômico: tradições vivas que davam identidade nacional ao reino do Norte, antes que fosse duramente abalada com a queda de Samaria. Contudo, as suas tradições permaneceram vivas e teriam sido levadas para o reino do Sul, onde, provavelmente, aconteceu uma fusão das tradições do Norte e do Sul. Estas, porém, teriam prevalecido sobre aquelas. ${ }^{65}$

\footnotetext{
${ }^{58}$ RÖMER, T., A chamada história deuteronomista, p. 24-25.

${ }^{59} \mathrm{O}$ indício principal que atesta a favor da hipótese de livro de Deuteronômio ter tido sua origem no reino do Norte são os levitas, que desde a época de Salomão, haviam se localizado no Norte (STORNIOLO, I., O Livro do Deuteronômio, p. 26-27).

${ }^{60}$ A fragilidade do reino dividido não impede que o livro de Deuteronômio se dirija a "todo o Israel" (LÓPEZ, F. G., El Deuteronomio - una ley predicada, p. 11). "A primeira edição de Deuteronômio pode muito bem ter sido escrita sob Josias. A última revisão, provavelmente incluindo o motivo da descoberta do livro, foi feita durante o período persa" (RÖMER, T., A chamada história deuteronomista, p. 55-61.71-76).

61 "Os estudos recentes admitem que o livro tem uma história de pelo menos 350 anos, de 750 a.C. a 400 a.C. Trata-se de um período longo e muito significativo, pois foi o tempo de grandes agitações nacionais e internacionais, com problemas econômicos, políticos, sociais e religiosos que trouxeram desafios fundamentais para a vida de Israel" (STORNIOLO, I., O Livro do Deuteronômio, p. 23).

${ }^{62}$ De Wette foi o primeiro a falar de uma redação deuteronomista (RÖMER, T., A chamada história deuteronomista, p. 25).

63 "Esses anciãos eram os chefes da comunidade e tinham a responsabilidade da manutenção das tradições de Israel” (LUZA, N., Uma Introdução ao Pentateuco, p. 45).

${ }^{64}$ HARRINGTON, W. J., Chave para a Bíblia, p. 223.

${ }^{65}$ ROSE, M., Deuteronômio, in RÖMER, T.; MACCHI, J. D.; NIHAN, C. Antigo Testamento, p. 267-268.
} 
Nesse sentido, o livro de Deuteronômio foi sendo "moldado aos poucos, por um longo crescimento orgânico de suas tradições a partir de cerimônias de renovação da aliança e recitações da Lei" ${ }^{66}$ Em sua estrutura o livro apresenta sinais que indicam um longo e importante processo de crescimento redacional. ${ }^{67}$

Uma hipótese ainda em voga, acredita que os sacerdotes levitas do Norte tenham sido os portadores das tradições, mas a forma final do livro de Deuteronômio deveu-se a habilidosas mãos judaítas. ${ }^{68}$ Estudos antigos evidenciaram a questão da linguagem sapiencial que foi utilizada pelo autor sagrado, também, as construções que se assemelham aos tratados assírios, e por último, os textos em estilo diplomático, indicando assim, uma autoria por parte de funcionários da corte ou escribas. Sugere-se que círculos proféticos tenham interagido também em certas partes do livro, devido as questões socioeconômicas abordadas no conjunto legisltativo. ${ }^{69}$

Há cinco razões para se afirmar que o livro de Deuteronômio, dentro do processo de formação do Pentateuco, recebeu sua forma atual por volta de 400 a.C.:

1) Não se consegue verificar no Pentateuco a influência do helenismo; $;^{70}$

2) Os samaritanos assumem o Pentateuco como Sagrada Escritura após o seu rompimento cultual-religioso com Jerusalém. Isso ocorre num tempo um pouco anterior à presença de Alexandre Magno nessa região (cerca de 330 a.C.), o que vai ocasionar uma grande influência helenista em toda a região. Sendo assim, tudo indica que a formação do Pentateuco aconteceu em ambiente persa, quando

\footnotetext{
${ }^{66}$ GOTTWALD, N. K., Introdução Socioliterária à Bíblia Hebraica, p. 364-365.

67 "As variações de estilo, as quebras de sequência e as pequenas unidades autossuficientes fazem pensar que o livro se formou aos poucos" (STORNIOLO, I., O Livro do Deuteronômio, p. 23). "Além disso, o estilo e o vocabulário de Deuteronômio eram considerados a marca de transição para tendências mais recentes, estando na mesma classe de outros escritos do séc. VII a.C." (THOMPSON, J. A., Deuteronômio Introdução e Comentário, p. 58).

${ }^{68}$ RAD, G. V., Studies in Deuteronomy, p. 60-69.

${ }^{69}$ Foi no tempo de Ezequias e Josias diante das reformas empreendidas em seus governos, que vem à tona a procedência cultual da aliança/lei e é a partir de então, que "os sacerdotes levitas em Jerusalém e os funcionários da corte, foram sem dúvida colaboradores em realizar reformas e em moldar o texto de Deuteronômio. Ao mesmo tempo, a pregação dos profetas do séc. VIII, Amós e Oséias no Norte e Miquéias e Isaías no Sul, havia sensibilizado sacerdotes e funcionários do governo para as urgências de justiça socioeconômica, que encontrou igualmente forte expressão nas leis de Deuteronômio" (GOTTWALD, N. K., Introdução Socioliterária à Bíblia Hebraica, p. 366).

${ }^{70}$ Uma posição a favor dessa influência encontra-se em: WAJDENBAUM, P., Argonautas do deserto, p. 7-116. Especificamente sobre o livro de Deuteronômio, p. 241-258.
} 
Samaria ainda era a satrapia pela qual a Persia controlava Judá-Jerusalém como se encontra na narrativa contida nos livros de Esdras e Neemias;

3) A tradução da Torá para o grego ocorreu, provavelmente, em meados do séc. III a.C., o que indica que ela deve ter obtido aceitação em diversas regiões, inclusive na diáspora egípcia (Alexandria e Elefantina);

4) Os importantes livros de Esdras e Neemias têm como premissa a "Torá de Moisés" (Esd 3,2; Ne 10,30; 13,1), inclusive Ne 9 possui um resumo que abarca de Gn à aflição causada pelo exílio em Babilônia e Ne 10 comenta textos de Ex-Dt;

5) Segundo a hipótese de Georg Braulik (1941-), a redação final do livro de Deuteronômio deve ser datada por volta de 400 a.C., onde está em conexão com a inserção do livro de Deuteronômio no Pentateuco. Portanto, é provável que a conclusão do Pentateuco tenha ocorrido no início do séc. IV. ${ }^{71}$

Em suma, o livro de Deuteronômio primitivo deve estar conformado basicamente por uma versão prévia do atual Código Deuteronômico (Dt 12-26*) junto com sua introdução (Dt 6,4-9) ${ }^{72}$ e conclusão (Dt $28,1-46^{*}$ ). Seu contexto histórico foi o dos sécs. VIII e VII a.C., em plena dominação assíria de Israel (conquistada por volta de 722/1 a.C.) e Judá (sob a forma de vassalo), e particularmente, coincidindo com a reforma de Josias (639-604 a.C.). O restante do livro (Dt 1-4; 9,7-10,11;28,47-68; 30-34) resulta de alargamentos posteriores ou de edições feitas durante o exílio e após o exílio. ${ }^{73}$

\section{3.}

\section{A figura do grande líder: Moisés}

Moisés, o grande líder, foi vocacionado por YHWH e vai assumir diversos papéis em sua missão de conduzir o povo do Egito à terra de Canaã. É impressionante o seu protagonismo na história do povo escolhido. $\mathrm{O}$ homem que conversava "face a face" com YHWH, também empresta sua voz para ordenar a proclamação e o ensino da Lei, através de seu livro (Dt 31,24-27), que será a base

\footnotetext{
${ }^{71}$ ZENGER, E. et. al., Introdução ao Antigo Testamento, p. 52.

${ }^{72}$ Interessante perceber que em Dt 6,15, o autor sagrado alude a questões futuras, como: o fim dos profetas anteriores, a destruição de Jerusalém e a deportação do povo. Se tem, provavelmente um indício de que o livro foi escrito justamente na época em que esses episódios aconteceram (RÖMER, T., A chamada história deuteronomista, p. 10).

${ }^{73}$ AZCÁRATE, J. L. L., Deuteronomio, p. 25.
} 
e o instrumento pedagógico para o cumprimento da aliança entre YHWH e Israel. A Lei vem como dom de YHWH a seu povo, mas este deveria absorver suas palavras e ensinamentos como regra de vida. ${ }^{74}$

YHWH, por Moisés elege e legisla para Israel. ${ }^{75} \mathrm{O}$ conhecimento da $\mathrm{Lei}^{76}$ é o ponto estratégico para garantir o cumprimento da aliança estabelecida entre YHWH e Israel. Moisés encarna e deixa a Lei como fundamento sólido ${ }^{77}$ para garantir a vitória de Israel, mediante a obediência e a fidelidade a YHWH. ${ }^{78}$

Segundo a lógica narrativa, o livro de Deuteronômio se tornou o material didático que o grande líder e mestre de Israel produziu para servir como apoio pedagógico àqueles que iriam continuar a sua obra, pondo em prática a Torá, instruindo as futuras gerações. Moisés, portanto, é o principal pedagogo levantado por YHWH, que vai conduzir Israel ao conhecimento, aprendizado e ao comportamento conforme a Lei recebida com dom libertador. ${ }^{79}$

Apreciando Ex 24,3-7, se pode notar que Moisés é o primeiro "escriba" de Israel, indicado pelo verbo: "e referiu" (ויספר), que provém do substantivo "livro" (ספֶֶ). Portanto, Moisés é aquele que sabe "narrar" (ספר), sabe "escrever" (כתב) e sabe "ler" (קרא). Estes verbos caracterizam a pessoa e as ações de Moisés. ${ }^{80}$

No coração da libertação, vivida por Israel, Moisés se destaca como mediador da palavra e da ação de YHWH em prol de um povo humilhado e

\footnotetext{
${ }^{74}$ LÓPEZ, F. G., El Deuteronomio - una ley predicada, p. 25.

${ }^{75}$ Atuação de Moisés como legislador: Ex 20,22; 24,12; 31,18; Lv 1,1-2; 6,1-2; 7,28-29; Nm 5,12 ; Dt 1,1-2; 4,44-45; 31,24. Também fora do Pentateuco se encontram textos que aludem à sua atividade como legislador: Js 1,$8 ; 8,31-35 ; 23,6 ; 24,25-26$.

${ }^{76}$ O NT também fala de Lei: Mt 5,17; 7,12; 11,13; 22,40; Lc 2,22.24.27.39; 16,16; 23,56; Jo 1,17; $7,19.23 .49 ; 19,7$; At 6,$13 ; 7,53 ; 13,38 ; 15,15 ; 21,28 ; 23,3 ; 28,8 ;$ Rm 2,12-14.25.27; 3,19.27.31; 5,$15 ; 5,20 ; 6,15 ; 7,1.7-9.12 .14 .23 ; 8,2-3 ; 9,4 ; 13,8 ; 1$ Cor 9,$8 ; 14,34 ; 15,56 ;$ Gl 2,14.19; 3,5.12.17.19.21.24; 4,21; 5,3-4.14.18.24; 6,2-13; 1Tm 1,8-9; Hb 7,5.16.19.28; 8,4; 9,19.22; 10,2.8.28; Tg 1,25; 2,8.10; 4,11 (SKA, J. L., O Antigo Testamento: Explicado aos que conhecem pouco, p. 51).

77 Conforme LIMA, M. L. C., (A Palavra de Deus em palavras humanas, p. 18): "Não é mais Moisés quem, de viva voz, transmite os ensinamentos divinos recebidos no Sinai (cf. Ex 19,3-8), mas a palavra escrita, que expressa esses ensinamentos. O povo se prosta, pois, mediante a Palavra, sabe-se diante de Deus".

78 "Com plena confiança na presença de Deus em seu meio, o exército do Senhor não poderia deixar de ser vitorioso na conquista e, em breve, a terra que tinha sido prometida há tanto tempo seria realmente sua herança" (CRAIGIE, P. C., Comentários do Antigo Testamento Deuteronômio, p. 358).

79 "O livro de Deuteronômio vivamente preocupado com a educação de Israel se apresenta como Torá (Dt 1,$5 ; 4,44 ; 17 ; 18 ; 31,26)$ e é assim designado em 2Rs $22,8.11$. É certo que ele contém muitas leis, mas não é menos certo que estas têm traços particulares. As leis de Deuteronômio não são estritamente jurídicas, e seu objetivo não é a organização política do Estado. A lei deuteronômica é "lei pregada"” (LÓPEZ, F. G., El Deuteronomio - una ley predicada, p. 24).

${ }^{80}$ SKA, J. L., O Canteiro do Pentateuco, p. 205-206.
} 
oprimido. ${ }^{81}$ Impressiona ver os inúmeros papéis desempenhados por este notável líder, durante o período que esteve à frente de Israel, desde a libertação do Egito até a chegada nas estepes de Moab, onde encerrou sua carreira. ${ }^{82}$

Moisés figura como um homem de muitos talentos e dons. Muitas são as características que fazem parte de sua personalidade. A sua grandeza não estava na educação recebida como filho adotado da filha do Faraó, nem tão pouco na possibilidade de herdar o trono da nação mais poderosa da época, mas sim por ter uma simpática e solícita generosidade com os fracos e oprimidos (Ex 2,11-22). ${ }^{83}$

Se pode dizer, que Moisés foi um insistente e perseverante negociador junto ao Faraó para libertar o povo e operou diversos prodígios diante dele. Foi um homem de fé absoluta no Deus de Israel (Eclo 45,27-46,6; Hb 11,23-29) e demonstrou sua coragem e confiança ao empreender o êxodo, atravessando o Mar dos Juncos até alcançar o deserto e se livrar do exército do Faraó. Foi o mediador ${ }^{84}$ da aliança no Horeb/Sinai. Foi legislador, mestre e pedagogo durante a caminhada no deserto, pois ensinava a Lei que praticava. Foi quem comandou a construção do tabernáculo e designou o ofício dos sacerdotes, segundo as determinações de YHWH. Foi, também, comandante-chefe militar contra alguns povos de Canaã, que teve que enfrentar antes da travessia do Jordão, na Transjordânia. Foi juiz em diversas situações dentro da comunidade. Apesar de não ter sido "rei', se pode dizer, que Moisés foi equiparado a um rei, pois ele tinha autoridade sobre todas as tribos de Israel, assemelhando-se assim, a um monarca. Foi também escritor, pois segundo a ordem de YHWH, escreveu o livro da Lei. E como relata o livro de Deuteronômio ele foi o maior dos profetas do AT. ${ }^{85}$

\footnotetext{
${ }^{81}$ WÉNIN, A., O Homem Bíblico, p. 84.

${ }^{82} \mathrm{Na}$ Sagrada Escritura a única pessoa que se tem informação que tenha sido sepultada pelo próprio Deus foi Moisés. "Moisés subiu ao monte Nebo, ao cume de Pisga" (Dt 34,1). O topo do Monte Pisga chega a alcançar 1.371 metros de altura. No entanto, lá estava Moisés, com cento e vinte anos, subindo até o pico do monte (SWINDOLL, C. R., Moisés: Um homem dedicado e generoso, p. 382.394).

83 "Fica evidente que Moisés recebeu a melhor educação disponível na época, pela declaração de Estevão em At 7,22a: "[Moisés] foi instruído em toda a ciência dos egípcios". A tradição egípcia indica que ele deve ter estudado no Templo do Sol, em Heliópolis (LINDSAY, G., Moisés, o libertador, p. 7.13).

84 "A função mediadora de Moisés parece inegável. Ele era o mediador da palavra que lhe vinha de Deus e que devia transmitir fielmente aos homens. Assim se delineia o retrato ideal de Moisés como profeta e do profeta como Moisés" (LÓPEZ, F. G., El Deuteronomio - una ley predicada, p. $60)$.
}

${ }^{85}$ GOTTWALD, N. K., Introdução Socioliterária à Bíblia Hebraica, p. 192. 
Dentre as inúmeras características desse grande homem de Deus, está também, a função de intercessor, que aparece em diversos textos: ele salva o povo

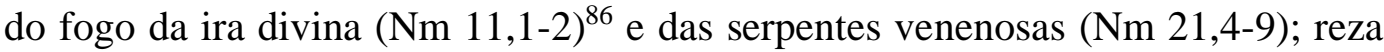
em favor de sua irmã Maria, castigada com lepra (Nm 12,11-16), e de seu irmão Aarão (Dt 9,20). Mas a maior oração de intercessão é sem dúvida aquela que fez depois que os israelitas adoraram o bezerro de metal fundido, oferecendo a sua própria vida (Ex 32,11-14.30-35; Dt 9,7-19). Esta forma, que é própria do caráter de Moisés, está estreitamente ligada a um traço característico de sua pessoa: a intimidade com $\mathrm{YHWH}^{87}$ com quem falava face a face, como a um amigo. ${ }^{88}$

Moisés é o líder dos filhos de Israel, ${ }^{89}$ seu guia através do deserto até o monte Horeb/Sinai, onde o povo liberto vai viver uma experiência decisiva com seu libertador. O povo inteiro ouve a voz de YHWH e, através de Moisés, é convidado a fazer uma aliança (Ex 19,24). YHWH quer ser o Deus de Israel, para fazer dele o seu povo, a sua propriedade (Ex 19,5-6; Dt 7,6). Aqui se tem a fórmula da aliança que é apresentada, principalmente, em Dt 26,17-19 e expressa a reciprocidade de ambas as partes se tratando de um contexto amoroso, pois YHWH ama Israel e Israel deve amar YHWH (Dt 6,5; 7,6ss; 10,12ss). Tudo acontece por iniciativa do próprio $\mathrm{YHWH}^{90}$

Curioso ver que o livro de Deuteronômio se dedicou a guardar a memória de um único dia: o último e memorável dia da vida do grande protagonista da história de Israel. ${ }^{91}$ Estava próximo o fim da vida e da missão de Moisés e como ele era um servo justo e fiel, deu total atenção e cumprimento à vontade de YHWH. Proferiu quatro discursos ${ }^{92}$ em seu último dia de vida e ainda deixou a Lei por escrito. Desta forma, na dinâmica do livro de Deuteronômio, os quarenta anos de peregrinação no deserto são reprisados em apenas um dia.

\footnotetext{
${ }^{86}$ Segundo Freitas, T., (Análise exegética de Nm 18,1-7, p. 22): "Vale ressaltar que a ira de YHWH faz parte de sua pedagogia, que age com firmeza e, ao mesmo tempo, com benevolência, a fim de formar a comunidade no deserto e educá-la na santidade. As próprias tradições bíblicas sucessivas irão corroborar esse argumento (Dt 8,5; Jr 31,9; Sl 103,13-18; Pr 3,12)".

${ }^{87}$ Ex 20,21; 24,18; 33,11; Nm 12,7-8; Dt 34,10.

88 "A intercessão é uma das funções-chave que se vai encontrar, posteriormente, em grandes profetas como Jeremias e Amós" (PEREGO, G., Atlas Bíblico interdisciplinar, p. 22).

89 “O povo hebreu não surgiu do nada, e sua cultura não foi transplantada diretamente do céu. Ela foi produzida no mundo, em contato com outras culturas, a partir de contextos de tempo e espaço muito específicos" (REINKE, A. D., Os outros da Bíblia, p. 64).

${ }^{90}$ LÓPEZ, F. G., El Deuteronomio - una ley predicada, p. 70.

${ }^{91}$ GALVAGNO, G.; GIUNTOLI, F., Pentateuco, p. 109.

92 PAPOLA, G., Deuteronomio. p. 14. SKA, J. L. O Canteiro do Pentateuco, p. 215.
} 
Moisés em seu primeiro discurso relembra ${ }^{93}$ o passado (Dt 1-4). Esses eventos passados enfatizam para o povo a importância do momento presente. O evento mais importante foi o êxodo do Egito seguido da aliança no Horeb/Sinai. É, portanto, a projeção no presente da história passada com a finalidade de lançar as bases para a história futura. Uma história que nunca poderá ser esquecida. ${ }^{94}$

Em seu segundo discurso (Dt 4,44-28,68), Moisés reflete sobre a aliança estabelecida com a primeira geração, a que saiu do Egito. O terceiro discurso contém a renovação da aliança feita nas estepes de Moab com a segunda geração, a que nasceu no deserto (Dt 28,69-30,20). Enfim, o quarto discurso, que é subdividido em diversas falas (Dt 31,1-33,29), correspondem às últimas ações de Moisés antes da sua morte..$^{95}$

Na dinâmica desse contexto, Dt 31, além de todas as falas de Moisés, pequenos discursos ${ }^{96}$ - abrange também a ordem de YHWH, para que Moisés escrevesse o cântico, que foi proclamado para todo o povo (Dt 32). Em seguida Moisés abençoa as doze tribos de Israel (Dt 33). ${ }^{97}$ A jornada do grande líder é finalizada com a narrativa da visão de Canaã, da sua sepultura, do seu luto, da sua singularidade e do encargo passado a Josué (Dt 34).

Em síntese, os discursos de Moisés, que ocupam quase a totalidade do livro, tinham a intenção de fixar de modo adequado e eficaz a memória do que se experimentou depois da libertação do Egito, fazendo um retrospecto de toda a história de Israel e exortando-os a uma firme observância dos termos da aliança, para não comprometer futuramente o dom da terra que Israel estava para

\footnotetext{
${ }^{93}$ Moisés relembrou, fez memória: "A memória tem muitas maneiras de prolongar no presente a eficácia do passado. Em hebraico, os sentidos do verbo זכר, em suas várias formas, dão disso uma ideia: lembrar-se, recordar, mencionar, mas também conservar e invocar, ações todas essas que desempenham um papel dos mais importantes na vida espiritual e na liturgia" (BENOIT, P., Vocabulário de teologia bíblica, p. 571).

${ }^{94}$ CRAIGIE, P. C., Comentários do Antigo Testamento - Deuteronômio, p. 18.

${ }^{95}$ SKA, J. L., O Antigo Testamento, p. 35.

${ }^{96}$ Quanto ao capítulo 31 do livro de Deuteronômio, a relação temporal existente entre os vv. 1-29 é bastante interessante, pois cada seção equivale a uma época diferente de redação. Dt 31,9-13, é a parte mais antiga e pertence a primeira edição da Escola Deuteronomista, foi escrita antes do exílio da Babilônia e abarca o período que vai de Salomão até Josias (900 - 600 a.C.). Dt 31,1-8 pertence a terceira edição da Escola Deuteronomista e foi escrita durante o exílio (586 - 538 a.C.). Já Dt 31,14-18 pertence a quinta edição e foi escrita após o exílio e equivale as narrações elohístas (STORNIOLO, I., Como ler o livro de Deuteronômio, p. 30-31).

97 “De Abraão, pelo qual todos os clãs da terra serão abençoados (Gn 12,3), a Moisés, que antes de morrer deu a bênção aos filhos de Israel (Dt 33,1-29), sobressai a iniciativa de YHWH como condutor e pedagogo da história do povo eleito. É por essa história, segundo a narrativa bíblica, que igualmente YHWH se mostra condutor da história universal" (FERNANDES, L. A.; BATTISTA, G.; ALVAREZ, G. A. B., Bíblia e Catequese, p. 53-54).
} 
receber. ${ }^{98}$ Desta forma, se pode dizer que o livro de Deuteronômio começa fazendo uma reflexão sobre o passado, do qual Moisés fez parte, e termina refletindo sobre um futuro que não contará com a sua presença. ${ }^{99}$ Esta presença, porém, se encontrará no dom da Torá.

Sobre a figura ilustre que foi Moisés, Nm 12,3 oferece uma impactante definição: "era um homem muito paciente, o mais humilde dos homens de sua época" e Dt 34,10 atesta a singularidade de Moisés como profeta. ${ }^{100}$

A vida de Moisés pode ser subdividida em três momentos: quarenta anos no palácio do Faraó (Egito); quarenta anos em Madiã, como pastor de ovelhas e pai de família; e quarenta anos no deserto, cumprindo a sua vocação e missão (At 7). Apesar dos seus cento e vinte anos, morreu em pleno vigor (Dt 34,7). ${ }^{101}$

Moisés, o líder carismático e exímio pastor, conduziu o povo da escravidão para a liberdade, encarnando e exemplificando o carisma profético. Através de suas mãos, os filhos de Israel receberam as tábuas da Lei, para que pudessem entrar em Canaã (Dt 34,4). Como pode o grande líder e amigo de YHWH não entrar na terra prometida? ${ }^{102}$

Algo interessante aconteceu na aliança entre YHWH e Israel: ficou o registro de um tratado, o livro da Lei escrito por Moisés. Josué seguirá como o novo líder de Israel e comandará a conquista da terra. Mas, o papel de mediador, praticamente em todo o Pentateuco, evoca a transmissão da palavra de YHWH a Israel para o livro ${ }^{103}$ que seguirá com o povo sob a liderança de Josué (Dt 34,9). ${ }^{104}$

Dt 32,52; 34,1-4, relatam que, do monte Nebo, Moisés contemplou a terra, mas não pôde entrar. YHWH deu a ele a possibilidade de contemplar a sua

\footnotetext{
${ }^{98}$ GALVAGNO, G.; GIUNTOLI, F., Pentateuco, p. 109.

${ }^{99}$ HAMILTON, V. P., Manual do Pentateuco, p. 526.

${ }^{100}$ SKA, J. L., O Antigo Testamento: Explicado aos que conhecem pouco, p. 57.

101 Segundo LIVINGSTON, G. H., (Comentário Bíblico Beacon, p. 493): "O livro de Deuteronômio termina com um olhar para o futuro. Relembrando Dt 18,15-19 e afirmando que até então nenhum profeta como Moisés surgira, são fatores que apontam para aquele que, séculos mais tarde, ofereceu aos seus seguidores reunidos o cálice da nova aliança selada com o seu próprio sangue (Mc 14,23-24)".

102 RUSHANSKY, E., O Palco da História, p. 23.

103 "O verdadeiro soberano do país conquistado se trata de um livro: a Torá, que foi entronizado sobre o monte Ebal e ao qual todos devem obedecer. Desta forma, a lei em vigor na terra conquistada já é a lei de Moisés (Js 8,32)" (SKA, J. L., O Antigo Testamento: Explicado aos que conhecem pouco, p. 72).

${ }^{104}$ HAYS, J. D.; DUVALL, J. S., Manual Bíblico Ilustrado Vida. p. 119. "Numa palavra, a personalidade de Moisés está estreitamente unida por YHWH e Israel. Continua viva e presente na Torá, da qual YHWH, Jacó/Israel e o mesmo Moisés são indiscutivelmente os protagonistas" (LÓPEZ, F. G., O Pentateuco, p. 24.268).
} 
herança e de guardar a sua fé, pois chegara ao término a sua missão. ${ }^{105}$ Moisés fisicamente não entrou na terra, mas a sua memória e os seus ensinamentos entraram com o livro. Este, seguiu com o povo escolhido e consagrado para YHWH: a segunda geração, e o seu espírito profético com Josué: o seu sucessor.

YHWH constituiu um povo, marcado pela liderança de Moisés, com a finalidade, de servir como exemplo, e ser sinal de sua benevolência e de sua justiça para as futuras gerações. Espera uma resposta de amor, único caminho para o povo encontrar a completa felicidade, mas isso só será possível através da fidelidade e obediência à Lei e àquele que é o único Deus e Senhor: YHWH. ${ }^{106}$

Apesar de ter sido líder de todos os ofícios, ${ }^{107}$ Moisés era humilde, simples, solícito, obediente, amigo, sincero, justo e bom. O livro de Deuteronômio do início ao fim mostra Moisés sempre obediente à vontade de YHWH e paciente com o povo, apesar de toda dificuldade em lidar com a obstinação dos membros daquela comunidade. Era um homem de fé, temente a Deus.

Moisés apesar de ser um homem íntegro e fiel à sua missão de conduzir Israel para a terra de Canaã, sendo sempre sustentado pela presença de YHWH, conheceu alguns fracassos ${ }^{108}$ por não conter o povo em sua infidelidade $(\mathrm{Nm}$ $14,1-45 ; 20,1-13 ; 26,64)$, e por isso, também, não entrou na terra prometida. ${ }^{109}$

Dt 31,7-8 atesta um grande exemplo de humildade, obediência, fortaleza, desapego, amor e compromisso com a missão. Apesar de todos os acontecimentos

\footnotetext{
${ }^{105}$ Uma lição pode ser tirada sobre a morte de Moisés antes de entrar na terra prometida: "Israel não deve esperar a sua salvação dos líderes e poderosos soberanos, de uma cultura excepcional ou de um exército invencível. A sua salvação está na observância da lei de Moisés" (SKA, J. L., O Antigo Testamento: Explicado aos que conhecem pouco, p. 57).

106 "A lei não é jugo nem freio. A finalidade da lei não é impor obrigações caprichosas nem restrições arbitrárias, mas indicar o caminho da vida feliz. De forma repetitiva o Deuteronômio convida o povo à observância da lei, para que tudo lhe corra bem e possa prolongar seus dias na terra que YHWH the dará (Dt 4,40; 5,33; 6,2.18.24 etc)" (LAMADRID, A. G., História, Narrativa, Apocalíptica, p. 50).

${ }^{107}$ O NT cita Moisés setenta e nove vezes, número considerável, e procura manter as diferentes tradições sobre ele: legislador, mediador, precursor do Messias. Alguns exemplos: Mt 8,4; Mc 7,10; Lc 24,27-44; Jo 1,45; At 3,22.

108 "Qual foi a culpa de Moisés? É um dos quebra-cabeças mais complicados do Pentateuco. Talvez Moisés não devesse ter golpeado a rocha com o bastão, ou somente uma vez, e devesse contentar-se com falar à rocha, ou não devesse ter repreendido o povo, ou devesse ter agido mais prontamente, ou, ainda, não devesse ter feito o povo acampar em Cades, mas caminhar imediatamente para a terra prometida $(\mathrm{Nm} \mathrm{20,1)}$. Há muitas opiniões e nenhuma é deveras convincente" (SKA, J. L., O Canteiro do Pentateuco, p. 180).

${ }^{109}$ FREITAS, T., Análise exegética de Nm 18,1-7, p. 23. "Segundo a lógica narrativa do livro de Deuteronômio, tudo o que Moisés recebeu o Senhor, ele transmitiu, por sua vez, ao povo. É como um pai (ethos) que, antes de morrer, deixa a sua herança (logos) para o filho (pathos). Como o pai continua vivo no filho, Moisés, apesar de não entrar na terra, estará vivo na herança deixada ao ‘novo Israel”' (FERNANDES, L. A., Análise retórica de Dt 30,11-14, p. 17).
} 
que atingiram diretamente sua pessoa, Moisés não deixou de concluir tudo que lhe fora determinado por YHWH até encerrar totalmente a sua missão. Essa é a verdadeira marca de um herói. 110 "Homem de Deus" (Dt 33,1) é um elogio e uma bela expressão que retrata a modesta pessoa do grande líder. Já Dt 34,10-12 intensifica esse elogio de quem foi, na obediência a YHWH, exemplo para Israel e o maior dos profetas da história do povo escolhido.

Moisés foi o servo admirável e um gigante em vários aspectos. ${ }^{111}$ Ele é o homem dos ensinamentos de YHWH, em sua sabedoria aprendeu o que YHWH tinha de melhor: sua Lei. Não só aprendeu como também praticou e ensinou. E como sua própria vida pode testemunhar: "Ensinar, é fazer brilhar a verdade e a justiça no meio dos homens pela obediência a YHWH". ${ }^{112}$

Esta foi a vida do grande homem de Deus, um herói e o maior dos profetas, mas apesar da grandeza de sua missão e de tantos atributos e privilégios com respeito à sua pessoa não deixou de ser um servo fiel e obediente. No fundo e no fim, esta foi a sua maior grandeza!

\section{4. \\ De Moisés a Josué, uma pedagogia de liderança}

Moisés mudou o nome do filho de Nun de "Oséias" (Nm 13,8) para "Josué" (Nm 13,16). Provavelmente essa mudança tem a ver com os propósitos de YHWH para a vida de Josué, pois ao lado de Moisés, Josué vai sendo preparado gradativamente para assumir um lugar de liderança. A mudança do nome é sugestiva, e, por sinal, é um nome que vai apontar para a última e definitiva aliança que ocorrerá na plenitude dos tempos. ${ }^{113}$

Mesmo sem saber do projeto de YHWH a seu respeito, Josué estava sendo preparado na "escola" de Moisés para o futuro cargo de liderança. Ex 32,17-18 e

110 "Veja o quanto este grande e bom homem esteve ocupado em fazer o bem quando sabia que o seu tempo era curto. Como ele se apressou quando se aproximava de seu descanso" (HENRY, M., Comentário Bíblico Antigo Testamento, p. 561).

${ }^{111}$ SWINDOLL, C. R., Moisés: Um homem dedicado e generoso, p. 401.

${ }^{112}$ FERNANDES, L. A.; GRENZER, M., Êxodo 15,22-18,27, p. 175.

113 "O nome Oséias significa "ele salva", enquanto Josué significa "YHWH salva", a fim de que

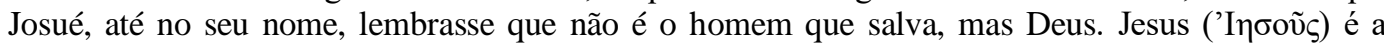

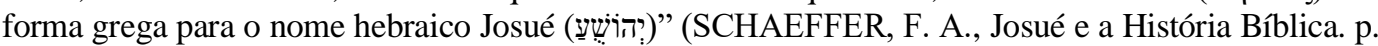
19). "Os nomes Josué e Jesus são, em hebraico, יְְiֹ: o Senhor salva. O que Deus operou através de Josué, de forma provisória, tornou-se uma imagem da libertação definitiva que Deus operou através de Jesus Cristo" (FERNANDES, L. A.; GRENZER, M., Êxodo 15,22-18,27, p. 200). 
Nm 11,24-29 atestam a correção de Moisés e o aprendizado de Josué em duas ocasiões singulares. No primeiro, o equívoco do sentido da audição dos gritos vindos do acampamento. No segundo, o texto diz que YHWH desceu na nuvem para operar um prodígio e imediatamente, os anciãos começaram a profetizar.

Nos dois casos, Moisés deu um grande exemplo de humildade e ensinou a Josué que liderança não é sinônimo de auto engrandecimento, pois a glória pertence somente a YHWH e, dentre o povo, YHWH pode agraciar quem ele quer com seus dons. ${ }^{114}$

Se pode citar outro exemplo que se relaciona com a escolha dos setenta anciãos que receberam o espírito profético e diz respeito ao mesmo episódio citado acima. Mas, agora, se refere a conduta de Moisés que servirá como exemplo de humildade e prudência, para seu educando, Josué. Se trata do conselho dado por Jetro. Ele consegue fazer Moisés enxergar o peso que estava carregando. Estava sobrecarregado e precisava organizar um conselho de anciãos para ajudá-lo a resolver os problemas que surgiam dentro da comunidade israelita. Seria, portanto, uma "descentralização do poder pela partilha das funções." Moisés, servo humilde, acolhe as orientações de seu sogro (ancião e sacerdote de Madiã), pois entendeu que "o conselho foi dado em nome de YHWH e debaixo da sua autoridade". 115

Ao lado de Moisés, Josué aprendeu muitas lições: Entendeu que YHWH não aceita rebeliões, murmurações, lamentações contra sua pessoa e, portanto, age com firmeza nessas ocasiões. Aprendeu que o poder e a vitória não se concentram nas mãos de um general, tudo depende da ação de YHWH. Aprendeu a mais bela lição: YHWH sempre está presente quando o povo é fiel. Aprendeu que o homem nunca conseguirá enganar YHWH, portanto, deve se manter longe do pecado. Respeitou e obedeceu a Moisés, mas sabia que o grande líder e guia do povo era YHWH, portanto, a glória a YHWH deve estar sempre em primeiro lugar. Entendeu que as regras são dadas por YHWH, jamais o homem pode impor regras a Deus. Compreendeu que a verdadeira liderança não vem de mãos humanas, mas do próprio YHWH, então tinha plena convicção que deveria submeter-se a ele e

\footnotetext{
${ }^{114}$ SCHAEFFER, F. A., Josué e a História Bíblica, p. 19.

115 Segundo FERNANDES, L. A.; GRENZER, M., (Êxodo 15,33-18,27, p. 156-159.190): "Moisés não possui o poder absoluto, mas possui uma graça absoluta: repartir com os homens escolhidos a sua vocação e missão".
} 
confiar na sua providência. E por fim, viu que YHWH mantém até o fim suas promessas. Foram quarenta anos nesse contínuo processo de preparação, agora Josué vai ser apresentado ao povo como o escolhido de YHWH (Nm 27,15-20), para finalizar a promessa do retorno à terra dos pais. ${ }^{116}$

Contudo, não só Moisés, mas, também YHWH tem uma "escola", e, por sinal, é uma instituição de ensino do mais elevado grau de valor moral, espiritual, intelectual e social. Para Josué, e inclusive, para todo o Israel a "escola" de YHWH foi o deserto, ${ }^{117}$ um campo árido, estéril, desolado, que YHWH colocou os filhos de Israel com o propósito de prepará-los para uma tarefa muito especial: o retorno à terra de seus antepassados. YHWH soube examinar o currículo de Israel através de sua experiência de vida no deserto, incutindo qualidades de caráter, que jamais poderiam obter de outra forma. E, Josué, foi aprovado no decorrer dessa trajetória, pois estava sempre próximo a Moisés, cumprindo tudo aquilo que lhe era atribuído, dando sempre o seu melhor, sendo obediente e fiel. Portanto, nada mais justo que fosse o escolhido para suceder o seu mestre. ${ }^{118}$

$\mathrm{Na}$ escola do deserto YHWH faz o povo passar por três situações, que merecem atenção especial: fome, sede e tempo. Em Ex 16,1-3 se tem o teste da fome, a seguir se tem o teste da sede (Ex 17,1-7), quanto ao teste do tempo: passar quarenta anos no deserto foi a maior provação. ${ }^{119}$

Em muitas qualidades Josué figura se assemelhar a Moisés: temente a YHWH e em tudo fazia a sua vontade. Era extremamente obediente e cumpridor de suas obrigações. Homem forte e valente, grande guerreiro, mas sabia onde depositava sua confiança. Tinha YHWH como seu Deus único e infalível. Procurava seguir o exemplo do grande mestre e como bom discípulo, aprendeu todos os ensinamentos, e foi exortado a colocá-los em prática (Js 1,1-9).

Não se tem melhor exemplo de obediência entre os israelitas do que o do jovem Josué. Como servo de Moisés, demonstrou interesse e estava sempre próximo ao mestre, para não deixar escapar nenhum ensinamento. Por Moisés foi escolhido como comandante do exército e sempre estava envolvido nas tarefas de

\footnotetext{
${ }^{116}$ SCHAEFFER, F. A., Josué e a História Bíblica, p. 27.

117 Deserto, em hebraico princípio se pode dizer que o deserto é, portanto, o lugar onde YHWH fala. É por excelência o lugar da Palavra (SWINDOLL, C. R., Moisés: Um homem dedicado e generoso, p. 89).

${ }^{118}$ SWINDOLL, C. R., Moisés: Um homem dedicado e generoso, p. 88-91.

${ }^{119}$ SWINDOLL, C. R., Moisés: Um homem dedicado e generoso, p. 269-277.
} 
confiança. Buscava ser eficiente em todas as funções que lhes eram atribuídas. Desta forma, YHWH o designou para ser o seu sucessor. E assim, o pequeno aprendiz se tornou também um grande líder como seu mestre. Quem começou como "servo de Moisés" (Js 1,1), terminou como "servo de YHWH” (Js 24,29).

Fato interessante se pode observar na investidura de Josué como novo líder. É de se admirar a postura de Josué frente a ordem de seu mestre. Moisés encoraja Josué (31,7-8), para a futura missão. Embora Josué fosse um general experiente e um homem de coragem, Moisés viu razões para encorajá-lo, pois precisaria ter muita força, agora que estava entrando em um novo cenário de ação. É bonito apreciar a atitude de Josué. Ele estava longe de ver nas palavras de Moisés uma afronta ou um questionamento da sua coragem. Pelo contrário, o próprio Josué fica muito satisfeito por ser orientado por Moisés a esforçar-se e animar-se diante da eminência de sua nova missão.

Da mesma forma se pode observar a postura de Moisés frente a entrega do seu posto de líder ao seu oficial. YHWH declara o fim de sua missão e Moisés prontamente acata sua ordem e passa o comando a Josué, pois ele não era apegado a cargos ou status e não olhou com maus olhos para o seu sucessor, nem tampouco torceu pelo seu insucesso, pelo contrário, Moisés se alegrou e deu todas as instruções necessárias para que Josué pudesse ser bem-sucedido. ${ }^{120}$

$\mathrm{Na}$ ação pedagógica de Moisés se pode destacar alguns recursos utilizados: seus discursos proferidos em tom parenético, as exortações, a mediação da aliança, o seu exemplo como um líder intercessor, legislador e mestre. Tudo foi ensinado e transmitido ao novo líder, que assumirá o comando e a missão de ser o novo mestre de Israel e condutor do povo à tomada de posse da terra.

O livro de Deuteronômio apresenta também outras estratégias utilizadas, como as repetições de frases importantes que são pontuais no livro e ajudam no processo de ensino-aprendizagem, pois a repetição é um meio fundamental para a memorização e é uma característica da literatura bíblica. ${ }^{121}$ Também funciona como um efeito estilístico que está muito presente no livro. Outro recurso

\footnotetext{
${ }^{120}$ HENRY, M., Comentário Bíblico Antigo Testamento: Gênesis a Deuteronômio, p. 658-659.

${ }^{121}$ ALTER, R., L'arte dela narrativa bíblica, p. 112-140.
} 
estilístico é o uso dos pronomes de segunda pessoa no singular e plural: tu/vós, quando se quer referir diretamente a Israel. ${ }^{122}$

Mas, a dinâmica mais incrível de ser apreciada nesse livro é descobrir que um livro inteiro está resumido em um único dia, o último dia da vida de Moisés. Os quarenta anos de história no deserto se resumem nesse momento de despedida - começo, meio e fim da história de Israel, se entrelaçam nesse único dia - que, provavelmente, é mais um ponto estratégico que YHWH utiliza para trazer à tona a temática que envolve a principal mensagem teológica do livro: a unicidade. ${ }^{123}$

Para aplicar esta didática, YHWH escolheu e inspirou gestores, capacitandoos a assumir a missão como pedagogos que têm a função de conduzir o educando ao aprendizado. O pedagogo é aquele que vai exercer o papel de facilitador da aprendizagem, ele deve, portanto, incentivar e introduzir os educandos dentro do mecanismo do processo. Desta forma, será possível alcançar com êxito o cumprimento da missão ao qual foram destinados, pois a aprendizagem passa pela afetividade e a afetividade estimula o desenvolvimento do saber. ${ }^{124}$

Moisés sempre confiou na força de YHWH e não na sua própria força. Por isso, YHWH sempre esteve ao seu lado. Não foi diferente com Josué, pois a sua vida ilustra perfeitamente esta verdade. O AT não aponta nenhum erro ou falha que esse novo líder - Josué - tivesse cometido. Infelizmente, Moisés apesar de ter sido um grande homem, dedicado e generoso, deixou-se levar pela ira mediante a insensatez daquele povo rebelde e falhou ( $\mathrm{Nm} 20,7-13) .{ }^{125}$

Mas apesar de ter falhado, Moisés se tornou útil nas mãos de YHWH, pois deixou-se conduzir pela sua vontade, de acordo com o seu plano pedagógico e de acordo com o tempo estabelecido por ele, pois o tempo de YHWH é perfeito. Desta forma, durante todos os anos que ficou peregrinando pelo deserto com o

\footnotetext{
122 “Analogicamente a alternância entre singular e plural da segunda pessoa, são considerados uma pista para se voltar a uma tradição dupla, é mais um estilo retórico que permite expressar a ligação necessária entre a resposta pessoal e comunitária ao apelo da lei” (PAPOLA, G., Deuteronomio, p. 20).

123 “O Deuteronômio apresenta a ideia da exclusividade de YHWH, sob uma forma absolutamente sucinta e programática que, em hebraico, compreende apenas quatro letras (Dt 6,4). Certamente a unicidade de YHWH ainda não é uma confissão monoteísta, porém é um elemento preparativo" (ROSE, M., Deuteronômio. In: RÖMER, T.; MACCHI, J. D.; NIHAN, C. Antigo Testamento, p. 277).

124 "A afetividade desempenha um papel fundamental na constituição e funcionamento da inteligência, determinando os interesses e necessidades individuais" (ANTONINO, E.; VIGAS, M. C.; PEIXOTO, M. F., Ação Psicopedagógica, p. 56).

${ }^{125}$ SWINDOLL, C. R., Moisés: Um homem dedicado e generoso, p. 377.
} 
povo da promessa continuou seu ensino e cumpriu sua missão até o fim, até o instante final de seu último suspiro, quando então nos braços de YHWH morre. ${ }^{126}$

O livro de Deuteronômio se apresenta, portanto, como uma obra fortemente didática, motivada pelo desejo de educar. Assim, sendo, as frequentes repetições podem ser interpretadas como um método pedagógico para impressionar o ouvinte com a mensagem do livro e ajudá-lo a assimilar seu conteúdo. ${ }^{127}$

Apesar de Josué ter inúmeras características semelhantes a Moisés, algo se diferenciava em sua missão como líder de Israel. Moisés possuía uma primazia, era aquele que ficava na presença de YHWH e conversava com ele "face a face", enquanto Josué somente ouvia à voz de YHWH. ${ }^{128} \mathrm{O}$ grau de intimidade entre Moisés e YHWH era impressionante.

De Moises a Josué temos uma pedagogia comprometida com a fidelidade à missão, onde o grande Pedagogo - YHWH - se faz presente, acompanhando os passos dos gestores que se encontram à frente de Israel conduzindo o povo à sua meta final: chegar à terra de Canaã; mas, ao mesmo tempo, se inicia outro desafio: permanecer na terra da promessa. Moisés e Josué foram excelentes pedagogos e souberam conduzir Israel, isto só foi possível porque foram obedientes a YHWH.

\footnotetext{
126 "Deve-se notar que estruturalmente a morte de Moisés no fim de Deuteronômio, corresponde ao livro de Gênesis: a morte de José concluiu os tempos dos patriarcas e a morte de Moisés concluiu a permanência de Israel no deserto e a constituição de Israel como povo de YHWH. As bênçãos de Jacó em Gn 49 correspondendo as de Moisés em Dt 33" (PAPOLA, G., Deuteronomio, p. 17).

${ }^{127}$ PAPOLA, G., Deuteronomio, p. 20.

${ }^{128}$ SWINDOLL, C. R., Moisés: Um homem dedicado e generoso, p. 390.
} 


\section{3 \\ Análise exegética de Dt 31,9-13}

\section{1.}

\section{Tradução segmentada}

E escreveu Moisés ${ }^{[a]}$ esta $^{[b]}$ Lei

e a deu aos sacerdotes, filhos de Levi, os que levam a arca da aliança de YHWH

e [deu] a todos os anciãos ${ }^{[c]}$ de Israel.

E ordenou-lhes Moisés,

dizendo $^{[\mathrm{a}]}$ :

"Ao final de sete anos,

por ocasião do ano da remissão,

na festa dos tabernáculos;

quando for todo o Israel

para se apresentar ${ }^{[a]}$ diante de YHWH,

teu Deus,

no lugar que escolherá ${ }^{\text {b- }}$

${ }^{b]}$ proclamarás ${ }^{[\mathrm{c}]}$ esta Lei,

diante de todo Israel, aos ouvidos deles.

Congrega o povo:

os homens, as mulheres,

as crianças ${ }^{[\alpha]}$ e o teu estrangeiro,

que [está] dentro dos teus portões;

para que ouçam

e para que aprendam

e temam a YHWH, vosso ${ }^{[\mathrm{a}]}$ Deus

e observem

para cumprir todas as palavras

desta Lei;

e os filhos deles,

que não conhecem,

ouçam
$12 \mathrm{~b}$

$12 \mathrm{c}$

$12 \mathrm{~d}$

$12 \mathrm{e}$

$12 \mathrm{f}$

$9 \mathrm{a}$

$9 \mathrm{~b}$

$9 \mathrm{c}$

$9 \mathrm{~d}$

$10 \mathrm{a}$

$10 \mathrm{~b}$

$10 \mathrm{c}$

$11 \mathrm{a}$

$11 \mathrm{~b}$

$11 \mathrm{c}$

$11 \mathrm{~d}$

$11 \mathrm{e}$

$12 \mathrm{a}$

$12 \mathrm{~g}$

$13 a$

$13 b$

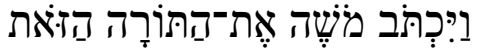

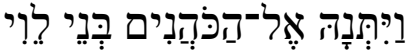

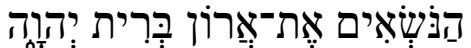

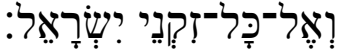

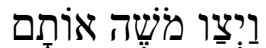

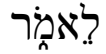

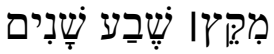

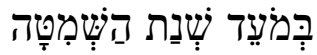

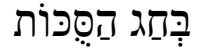

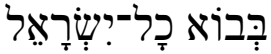

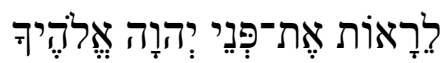

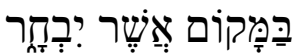

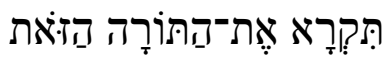

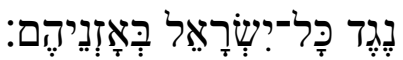

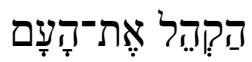

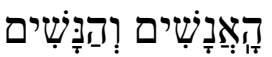

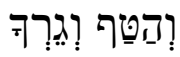

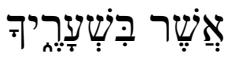

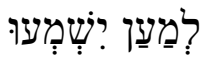

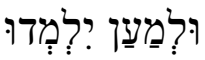

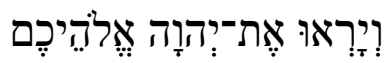

וְשׁשֶמרוּ

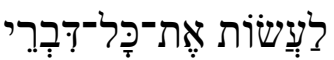

הַתּוֹרָה הַזּאת:

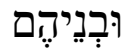

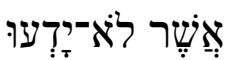

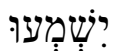




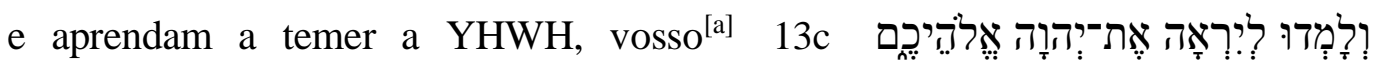
Deus,

todos os dias

$13 d$

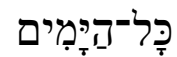

que vós ${ }^{[b]}$ vivereis sobre a terra,

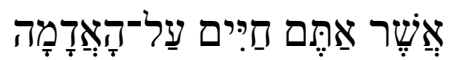

porque vós atravessareis o Jordão, $13 \mathrm{e}$ para ali, tomar posse dela".

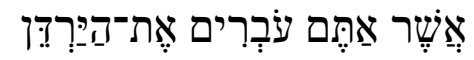

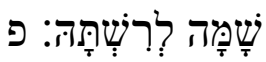

\section{2.}

Notas de crítica textual ${ }^{129}$

v. $9 \mathbf{a}^{[\mathrm{a} / \mathrm{b}]}$

A LXX, de forma isolada, traz um texto maior que o $\mathrm{TM}^{\mathrm{L}}$, pois, além de acrescentar um acusativo neutro, "as palavras" ou "os sentidos" ( $\tau \grave{\alpha} \rho \dot{\rho} \mu \alpha \tau \alpha)$, entre

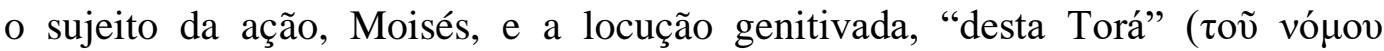

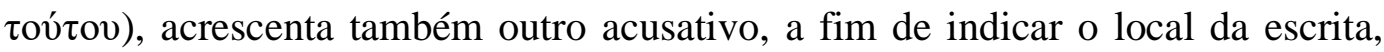
"no livro" (ciৎ $\beta ı \beta \lambda$ íov). O manuscrito 4QDeut ${ }^{\mathrm{h}}$ também traz esse acréscimo. Tais acréscimos parecem ser uma tentativa de harmonizar com Dt 31,24. Em ambos os casos, porém, a lição do $\mathrm{TM}^{\mathrm{L}}$ encontra-se, devidamente, apoiada pelo Pentateuco Samaritano, pela Vulgata e pela Peshitta, bem como nos Targumim.

v. $9 d^{[c]}$

O Pentateuco Samaritano, a Vulgata, a Peshitta, o Targum Onqelos e o Targum do Pseudo-Jonatas apoiam a presença do substantivo ذ̇ nל $\mathrm{TM}^{\mathrm{L}}$, texto maior que a LXX e o Targum Neofiti do Pentateuco. Em contrapartida, a LXX e um manuscrito da Peshitta, no lugar de "anciãos de" trazem "filhos de" Israel

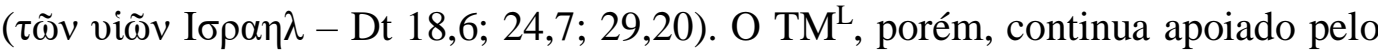
Pentateuco Samaritano, pela Vulgata, por manuscritos da Peshitta e pelo Targum.

v. 10b $b^{[a]}$

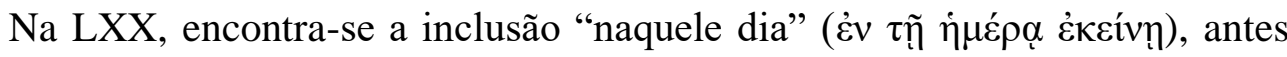
de לאלאר, como aparece em Dt 27,11. Apesar de mais breve, o $\mathrm{TM}^{\mathrm{L}}$ encontra-se devidamente apoiado pelo Pentateuco Samaritano, pela Vulgata, pela Peshitta e pelo Targum.

${ }^{129}$ As notas foram elaboradas a partir da BHQ ${ }^{\text {app }}$, 89-90. No caso do v. 12e seguiu-se BHS ${ }^{\text {app }}$. 


\section{v. $11 b^{[a]}$}

$\mathrm{BHQ}^{\text {app }}$ aponta que o Pentateuco Samaritano, a LXX, a Vulgata, a Peshitta e o Targum, ao invés da forma no nifal infinito construto: "para se apresentar" (לרָארז), traz no hifil infinito construto: "para se fazer ver" (להראות), como se encontra em Dt 3,24. Nota-se que a forma causativa busca enfatizar o sentido da ordem proveniente do Senhor. $\mathrm{BHQ}^{\mathrm{app}}$ sugere que, simplesmente, se leia no qal infinito construto: 130 "para ver” (לראוֹת), forma usada em Dt 29,3. A justificativa para tal conjectura apoia-se na ordem contida em Dt 16,16.

Contudo, não há razões para assumir a sugestão de mudança, pois o nifal infinito construto está, inclusive, condizente com Dt 16,16 que traz no yiqtol nifal terceira pessoa do masculino singular: "se fará ver" ou "se apresentará" (ירֶֶֶ.). A tradução, "para se apresentar", reflete bem o sentido de que cada filho de Israel tinha a obrigação de "comparecer" ou "se fazer ver", diante do Senhor, em uma das três festas prescritas na Torá.

\section{v. $11 \mathrm{~cd}^{[\mathrm{b}-\mathrm{b}]}$}

O Pentateuco Samaritano traz a sequência verbal no qal qatal e no qal yiqtol na terceira do singular masculino: "escolheu (בחר) proclamará (יקרא)". As duas ações têm YHWH como sujeito. Por detrás dessa sequência e por conta da rivalidade entre samaritanos e judeus, a lógica evidencia e salvaguarda a ideia de que YHWH teria escolhido o monte Garizim como local de culto e não Jerusalém. E YHWH, pelos lábios do sacerdote local, é quem proclamaria a Torá e não o fiel.

A formulação no qal yiqtol no $\mathrm{TM}^{\mathrm{L}}$, salvaguardando a respectiva diferença dos sujeitos das ações está condizente com a lógica interna do texto. Além disso, no contexto do livro de Deuteronômio, YHWH é o sujeito do verbo "escolherá" (יבחר) no qal yiqtol em referência ao futuro local de culto (Dt 12,5.11.14.18.21.26), e Dt 31,11 é a última ocorrência desse verbo. Não é preciso admitir a mudança.

\footnotetext{
${ }^{130} \mathrm{O}$ comentário ao aparato crítico da BHQ discorre sobre essa questão e afirma que a vocalização no nifal foi uma tentativa de correção teológica mais apropriada. Assim, ao invés de "ver a face de YHWH", algo que entraria em contradição com a fé comum segundo Ex 33,20, teria sido corrigido para "aparecer diante de YHWH" (BHQ, 136).
} 
V. $11 c^{[c]}$

Ainda quanto ao verbo "proclamarás" (תָּרְרָא), BHQ app anota que a LXX, ao invés do singular, traz a assimilação usual, na segunda do masculino plural:

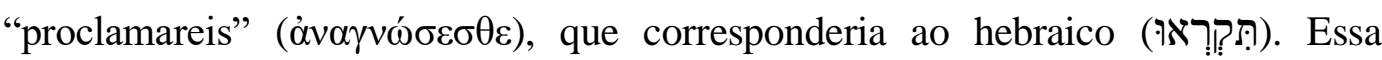
forma plural também está atestada no 4QDeut ${ }^{\mathrm{b}}$ e no Targum do Pseudo-Jonatas. A mudança tem a ver com a compreensão do coletivo, presente na locução, "todo o Israel", mas, principalmente, com a harmonização quanto ao problema, ao longo do livro de Deuteronômio, que se verifica entre "tu" (v. 11b) e "vós" (v. 12e).

Tal mudança não ocorre na recensão de Orígenes da LXX, que mantém a forma no singular como se encontra no $\mathrm{TM}^{\mathrm{L}}$ e está de acordo, também, com a Vulgata, a Peshitta, o Targum Onqelos e o Targum Neofiti do pseudo-Jônatas. Diante disso, a forma no yiqtol יקרא, presente no Pentateuco Samaritano, poderia ser considerada um erro de grafia.

V. $12 \mathbf{a}^{[\alpha]}$

No v. 12a, constata-se um particular, está dito para congregar "a criança", um substantivo masculino que está no singular. A sua tradução pelo plural justifica-se pelo fato de poder ser considerado, no hebraico, um substantivo indicador de coletivo, ampliando não apenas o alcance dos destinatários, mas, principalmente, mostrando a preocupação com as futuras gerações. ${ }^{131}$

v. $12 \mathrm{e}^{[\mathrm{a}]}$

A BHS ${ }^{\text {app }}$ indica que em vários manuscritos hebraicos, no minúsculo 107, no Pentateuco Samaritano e em um manuscrito da LXX, o substantivo plural “deuses" (אֶלהתים) aparece com o sufixo pronominal na terceira pessoa do plural, "Deus deles" (אלה הֶיהם), ao passo que o TM", a LXX e a Vulgata apresentam o sufixo na segunda pessoa do plural, “vosso Deus” (אֶלהּיכֶם).

\footnotetext{
${ }^{131} \mathrm{O}$ hebraico se distingue da língua portuguesa em muitos pontos, no que diz respeito ao plural e ao coletivo. "Em português nos referimos a um agregado de criaturas voadoras com um plural, 'pássaros', mas o hebraico usa o singular עוֹ; em contrapartida, o português usa um singular para referir-se à 'face' humana, mas o hebraico usa um plural, Tais discrepâncias existem porque nenhuma faceta da língua espelha o mundo diretamente. Número é uma categoria gramatical, como gênero, e assim, é parte de um sistema maior de uma determinada estrutura gramatical e lexical. Além disso, o uso de número revela até mesmo mais claramente o fato de que uma língua faz parte de uma cultura e é, por isso mesmo, moldada por aquela cultura" (WALTKE, B. K.; O’CONNOR, M. P., Introdução à sintaxe do Hebraico Bíblico, p. 111.114).
} 
O v. 12 começa com um imperativo, uma ordem dada por Moisés aos sacerdotes e anciãos: "congrega" (הקהקל). Esta ordem se refere diretamente a Israel, povo escolhido por YHWH. Sempre que o sufixo e o pronome aparecem na segunda pessoa do singular ou plural, é uma referência direta a Israel, povo eleito da aliança. O uso do sufixo na terceira pessoa do plural "Deus deles" (אֶלה (איהֶם), indicaria uma referência a algo ou alguém no diálogo entre duas pessoas (Moisés e Josué?).

No $\mathrm{TM}^{\mathrm{L}}$ do Livro de Deuteronômio encontra-se a forma comum, usada para indicar que a mensagem se direciona a Israel. Segundo a narrativa, Moisés se preocupa com a continuidade da instrução e com a fidelidade à aliança. Nesse caso, independe se está na segunda do masculino singular "teu Deus" (אָלֶהיף) ou na segunda do masculino plural "vosso Deus" (אֶלה הֶיכֶם), pois o povo pode ser tomado como tu ou como vós. ${ }^{132}$

\section{v. $13 \mathrm{c}^{[\mathrm{a}]}$}

$\mathrm{Na} \mathrm{BHQ}^{\mathrm{app}}$ ocorre a mesma variante do v. 12e contido na BHS ${ }^{\text {app }}$. Aponta-se que o Pentateuco Samaritano, a Vulgata e a Peshitta trazem a terminação do

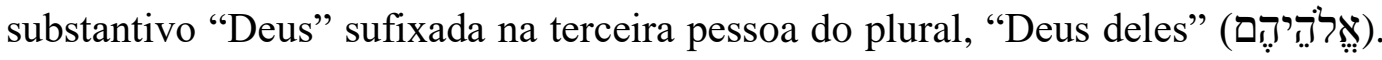
O códice Vaticano apresenta a forma na segunda pessoa do singular "teu Deus" (אֶ:ֶֶ), a fim de harmonizar com o v. 11b. Já no códice Basiliano-Vaticano e nos códices minúsculos, o substantivo está com o sufixo na primeira pessoa do plural, "nosso Deus" (אלה הצינוּ), indicando a inclusão de quem faz o discurso. Contudo, a lição do TM", "vosso Deus" (אֶלהּיכֶם), pode ser seguida, pois está devidamente apoiada pelo 1QDeut ${ }^{\mathrm{b}}$, pela LXX e pelo Targum.

Como foi citado no caso do v. $12 \mathrm{e}^{[\mathrm{a}]}$, quando se usa o pronome na terceira pessoa do singular ou plural, está se referindo a algo ou alguém. "Deus deles" está dando ênfase apenas a um determinado grupo de pessoas "os filhos deles", que é o sujeito da frase e o seu objeto é YHWH, que deve ser conhecido por "eles" (nova geração, que nasceu no deserto).

\footnotetext{
${ }^{132}$ No Deuteronômio o uso dos pronomes: "teu" e "vosso" é uma característica literária atribuída à mão Deuteronômico-Deuteronomista. Os pronomes possessivos, "nosso", "teu" e "vosso" são formas usadas para indicar a proximidade da relação que o ser humano pode ter com seu Deus, que não está distante, mas plenamente presente na vida do seu povo (LÓPEZ, F. G., O Pentateuco, p. 231-234. 239).
} 
O sufixo pronominal, “deles" poderia ser uma referência à primeira geração que saiu do Egito, mas que morreu no deserto devido à desobediência por ocasião da tomada de posse da terra (Nm 14,20-38). O TM ${ }^{\mathrm{L}}$ encontra apoio na LXX que usa o sufixo pronominal na segunda pessoa do plural: "vosso" (í $\mu \tilde{\omega} v)$. A mudança do sufixo pronominal sugere uma harmonização do texto.

v. $13 d^{[b]}$

A BHS ${ }^{\text {app }}$ indica que o Pentateuco Samaritano, a LXX e a Vulgata preferem o pronome pessoal na terceira pessoa do plural, “eles" (הָ); ao passo que o TM utiliza o pronome na segunda pessoa do plural, “vós” (אֶָּ)

Nesse caso, a terceira pessoa plural, parece promover um distanciamento, “eles" como "aquele povo". Seria uma referência ao povo de forma indireta, ao passo que "vós” seria direta. É possível que o pronome na terceira pessoa do plural, "eles" (הֶם) em Dt 4,10 tenha servido para a opção do Pentateuco Samaritano, da LXX e da Vulgata. Em contrapartida, no $\mathrm{TM}^{\mathrm{L}}$ a opção pelo

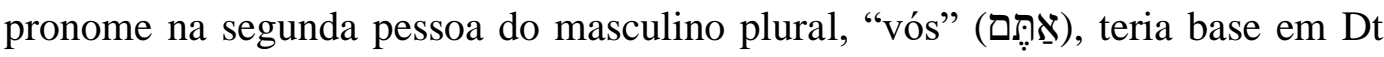
12,1, mantendo, assim a dinâmica da forma característica de se referir a Israel. ${ }^{133}$

Assim, os problemas textuais tratados não comprometem o sentido do $\mathrm{TM}^{\mathrm{L}}$. A sua autoridade textual prevalece e revela que foi transmitido com o devido cuidado, razão pela qual permanece a base para o trabalho de crítica textual. ${ }^{134}$

\section{3.}

\section{Delimitação, unidade e organização}

\subsection{1.}

\section{Quanto à delimitação}

Ainda que o protagonismo, quanto ao sujeito da fala, continue com Moisés, nota-se uma mudança quanto ao tema. Dt 31,1-8 tem a ver com a missão de Josué, ao passo que Dt 31,9-13 tem a ver com a escrita da Lei, a sua entrega aos sacerdotes da tribo de Levi e aos anciãos, bem como há a ordem da leitura ritual da Torá.

\footnotetext{
133 Seguiu-se o comentário ao aparato crítico da BHQ, 136.

${ }^{134}$ ECHEGARAY, J. G., al et. A Bíblia e seu Contexto, p. 474.
} 
De algum modo, esses dois textos podem estar em relação, visto que, pela lógica da narrativa, Josué deveria se encarregar de colocar em prática essa ordem no primeiro ano sabático a ser celebrado após a entrada e a conquista da terra de Canaã pelos filhos de Israel. A ordem de congregar o povo, na segunda pessoa do singular no imperativo hifil em Dt 31,12a הַקְהל, poderia estar dirigida a Josué.

Ao detalhar o conteúdo de Dt 31,1-8, vê-se que se trata de uma narrativa em prosa e que faz parte dos últimos atos de Moisés no livro de Deuteronômio (Dt 31,1-33,29). ${ }^{135}$ Em Dt 31,1-8, Moisés se dirige a Israel, informa a sua idade, cento e vinte anos (dado que se repete em Dt 34,7), e diz que não atravessará o Jordão, ou seja, está chegando ao fim de sua missão. Em seu lugar, Josué será o novo líder. Moisés motiva o povo com palavras de encorajamento, "Sede fortes e corajosos" (v. 6), e garante-lhes a presença de YHWH na jornada da conquista de sua herança - a terra prometida.

Ainda dentro deste discurso, Moisés fala diretamente a Josué diante de todo o Israel e repete as mesmas palavras: "Sê forte e corajoso". ${ }^{136}$ Transmite ao novo líder a continuidade de sua missão, motivando-o com palavras de confiança total em YHWH, o Deus justo e fiel, que fez aliança com eles (vv. 7-8). ${ }^{137}$

Nota-se que em Dt 31,1-8 o narrador introduziu o discurso direto de Moisés. No v. 1, a proposição verbal é iniciada com um wayyiqtol se traduz por "e andou", mas que pode ser traduzido por uma expressão temporal, "depois foi”, indica que tem início uma nova seção, estabelecida e marcada pela determinação temporal. No v. 2, novamente se verifica a presença do wayyiqtol, na fala de Moisés, discursando a Israel. Esta fala segue até o v. 6, pois no v. 7 acontecerá uma nova introdução narrativa, onde Moisés, agora de forma especial e

\footnotetext{
135 É possível subdividir o Deuteronômio com base na forma e no conteúdo do livro. Dt 31,133,29 seria a quarta parte, admitindo a singularidade do relato da morte e sucessão da liderança por Josué em Dt 34 (FERNANDES, L. A., Reflexão sobre o contexto e a singularidade de Dt 30,1114, p. 95-108).

136 “'O texto parece dizer: 'Sê forte e corajoso, Josué', porém não para promover guerra e enfrentar inimigos sobre o campo de batalha. A tua coragem deve ser mostrada, antes de tudo, na observância da lei de Moisés" (SKA, J. L., O Antigo Testamento: Explicado aos que conhecem pouco, p. 71).

137 "Os vv. 7-8 se referem à segunda intervenção de Moisés e aborda diretamente a sua sucessão

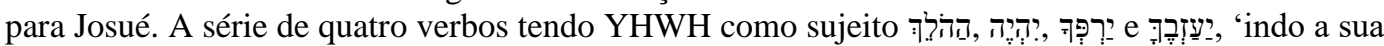
frente', 'estarei contigo', 'não te deixarei' e 'não te abandonarei', aparece somente neste texto (31,1-8). Os quatro verbos representam o ponto mais alto da comunhão entre YHWH e seu novo líder: Josué" (PAGANINI, S., Deuteronômio, p. 426).
} 
particular, se dirige a Josué, transmitindo instruções importantes relativas ao ofício que irá assumir. Desta forma, é concluída a primeira seção de Dt 31.

Na sequência, Dt 31,9-13 é uma nova fala de Moisés. Contudo, mudam as personagens e o enredo que são bem diferentes. A palavra de Moisés é dirigida aos sacerdotes, filhos de Levi, e aos anciãos, que serão os responsáveis por levar o livro da Lei junto da arca da aliança. A missão de congregar o povo para ouvir esta leitura parece, como acima referido, ter sido atribuída a Josué pela forma verbal no imperativo singular hifil. O ponto culminante dessa seção está na questão relativa à leitura da Lei. Quando ela deverá ser feita? Qual o tempo propício? Quem deverá participar dessa celebração? Em que lugar ela deverá ser proclamada?

Em Dt 31,1-8, além do protagonista, aparecem como personagens Israel e Josué. A mensagem principal é, diante do povo, apresentar o novo líder e encorajar a ambos sobre o enfrentamento e a tomada de posse da terra prometida. Já em Dt 31,9-13, muda completamente a cena, os ouvintes do discurso de Moisés agora são os sacerdotes, filhos de Levi, e os anciãos das tribos de Israel. O assunto principal é o livro da Lei. Muda a cena, mudam as personagens, muda o enredo, mas o protagonismo continua com Moisés.

Em Dt 31,1-8, o enfoque maior está na figura de Josué e sua futura missão. Apesar da relação apontada, em virtude do tema, se nota perfeitamente que se trata de duas perícopes independentes, bem estruturadas por vários elementos que compõem e distinguem cada cena com seu próprio enredo, onde se consegue perceber nitidamente, o início e o fim, de cada fala e sua respectiva cena.

No tocante ao texto subsequente, Dt 31,14-18, percebe-se uma retomada do interesse pela pessoa de Josué. YHWH é o sujeito da fala dirigida a Moisés, pois se aproxima o dia da sua morte. ${ }^{138}$ Nesse sentido, Dt 31,14-18 parece, de algum modo, continuar o que havia sido iniciado em Dt 31,1-8.

\footnotetext{
${ }^{138}$ A morte de Moisés fora da terra prometida não é uma punição, mas uma realização da promessa divina. Os cento e vinte anos de sua vida representam completude e plenitude. O livro de Deuteronômio dá o motivo de sua morte (Dt 1,26.34-37; 3,25-27). Segundo Gn 6,3, cento e vinte anos é o limite estabelecido por Deus para a duração da vida de um homem. Portanto, Moisés morre porque chegou ao limite de idade imposto por YHWH. Moisés morre porque a sua tarefa de transmissor da Torá com a colocação por escrito no livro está terminada (PAGANINI, S., Deuteronômio, p. 459-460).
} 
O tema da proximidade da morte de Moisés é retomado e consequentemente, a preocupação com a sucessão do líder. Josué foi o escolhido e segundo a ordem dada por YHWH a Moisés, os dois deveriam se apresentar na Tenda da Reunião, ${ }^{139}$ para ali receberem as instruções que serão dadas pelo próprio YHWH.

Dt 31,14-18 também é introduzido por um verbo no wayyiqtol - "e disse"

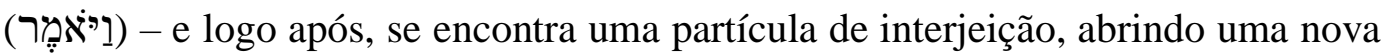
proposição, dando ênfase à fala de YHWH. Essa partícula pode ser traduzida por “eis que”. Nessa proposição, YHWH é o sujeito e a sua fala é dirigida a Moisés. Volta em cena Josué, que estava presente nos vv. 1-8 e ausente nos vv. 9-13, caso o v. 12a não se refira à sua pessoa. Então, nos vv. 14-18, o protagonista é o próprio YHWH, que fala diretamente a Moisés na presença de Josué. O episódio, porém, ocorre em outro ambiente, há uma mudança no local geográfico da cena, pois o lugar é determinado por YHWH e é considerado um lugar santo. ${ }^{140}$

Portanto, três pontos importantes podem ser destacados e permitem dizer que Dt 31,9-13 é uma seção independente: um local específico que difere do ambiente anterior, pois nos vv. 9-13 nada é informado (no próprio texto) acerca do local, sabe-se que os discursos de Moisés ocorreram nas estepes de Moab (Dt 1,1-5). O segundo ponto é a presença de outras personagens, que entram em cena ao lado de Moisés: YHWH e Josué. O terceiro ponto diz respeito ao tema, pois nos vv. 9-13 o enfoque está no livro da Lei e a sua proclamação. Sob este pano de fundo são dadas as ações futuras: a investidura de Josué como novo líder e a conquista da terra de Canaã.

\footnotetext{
139 "Tenda, literalmente tabernaculum, nome frequentemente usado em traduções para indicar a tenda sagrada do antigo Israel. A tenda tem dois nomes em hebraico: mishkan 'morada', significa que a tenda é o lugar onde YHWH habita no meio de seu povo. Este é o termo do templo comum no AOM. O outro nome, 'ohel mo'ede', 'tenda do encontro', é mais propriamente israelita. O 'encontro': não é o dos homens em assembleia cultual, porém o encontro de YHWH com Israel mediante Moisés. A tenda é o lugar da revelação" (McKENZIE, J. L., Tenda. In Dicionário Bíblico, p. 919). Segundo FREITAS, T., (Análise exegética de Nm 18,1-7, p. 19. 24): Também se pode dizer que YHWH habita no meio dos israelitas (Nm 14,14), com uma presença em sentido locativo, através de um objeto que o povo leva consigo: a Tenda da Reunião (Nm 10,35; 11,2425), pois se trata de um objeto desmontável e transportável (Nm 3,25-4,10; 10,17-21).

140 Segundo PAGANINI, S. (Deuteronomio, p. 427-428): "Pela primeira vez, dentro do Deuteronômio, a intervenção de YHWH não é mediada por Moisés, mas introduzida pelo narrador que propõe assim um verdadeiro discurso direto da divindade. YHWH quer se encontrar com o sucessor e dá a ele às suas ordens. O lugar designado para o encontro foi a tenda da reunião. Este santuário, característico do período de peregrinação no deserto, aparece pela primeira vez, em Deuteronômio, neste texto (Dt 31,14-18)".
} 
Entre os vv. 9-13 e 14-18 existe uma relação, pois o centro de tudo está no cumprimento da Lei que foi estabelecida por YHWH e escrita por Moisés no livro entregue aos sacerdotes e colocado ao lado da arca, seguindo com eles para a terra de Canaã, onde Josué, como "lugar tenente", a colocará em prática. Há uma relação no conteúdo e na finalidade, mas os discursos pertencem a seções distintas, pois houve mudança de foco na pessoa que profere o discurso, novas personagens foram introduzidas na cena e aconteceu um deslocamento geográfico.

A fala do narrador é constante nas seções introduzindo um novo discurso, marcado sempre por um verbo no wayyiqtol. Se percebe a mudança de assunto, apesar de haver uma perspectiva unindo Dt 31,9-13 ao texto subsequente, mas o argumento utilizado é outro. YHWH já prevê o que vai acontecer quando Israel tomar posse da terra e se misturar com os povos pagãos (v. 16), por isso institui o livro da Lei (v. 9). A fala é uma prolepse e serve de alerta, pois a geração que se seguirá à da conquista irá se corromper na idolatria e deixará de observar o livro da Lei. A cólera de YHWH se inflamará e ele os abandonará (v. 17). ${ }^{141}$

Dt 31,9-13 é iniciado por um verbo no wayyiqtol, um "tempo" que serve para assinalar um começo narrativo. O uso do wayyiqtol é característico da narrativa e evidencia a ação em primeiro plano. Assim sendo, marca o "início de uma unidade textual autônoma". ${ }^{142} \mathrm{Na}$ sequência, se tem outro wayyiqtol, dando prosseguimento a narração e em seguida o verbo vai para o yiqtol, esta mudança sugere o início de um discurso. No v. 10, o verbo encontra-se no grau piel e denota a forma intensiva na voz ativa. Moisés abre o discurso direto indicando o que deverá ser feito.

Assim sendo, verifica-se que Dt 31,9-13 começa com uma proposição verbal no wayyiqtol que introduz a narrativa, para se chegar ao discurso de Moisés que é iniciado por um yiqtol, pontos característicos da língua hebraica. ${ }^{143}$

\footnotetext{
${ }^{141}$ A escolha da vida em detrimento da morte é uma moldura no livro de Deuteronômio. A geração nascida no deserto teve, diante de si, a morte dos que saíram do Egito e testemunharam o fruto da desobediência. A escolha da vida é sinal de fidelidade e de amor a YHWH (WRIGHT. C. J. H., Deuteronomio. p. 427; PAPOLA. G., Deuteronômio, p. 341).

142 NICCACCI, A., Sintaxis del Hebreo Bíblico, p. 159.161.

143 As formas verbais do wayyiqtol e yiqtol são fundamentais da prosa hebraica e foram identificadas mediante a oposição entre mundo narrado (wayyiqtol) e mundo comentado ou "discurso" (yiqtol). As sequências narrativas são caracterizadas tanto pela combinação do qatal com o yiqtol, como do yiqtol com o qatal. A conjunção waw na sequência narrativa pode assumir tanto a função "conversiva", como "consecutiva". A lógica temporal hebraica deve ser preservada ao máximo na tradução (LAMBDIN, T. O., Introducción al Hebreo Bíblico. Lição 24, p. 106-107).
} 
No início do texto, a cadeia de wayyiqtol, vem formando uma série de orações coordenadas que estão reputadas como continuação da anterior, mas serve também como "ponte" para os segmentos posteriores.

Outra característica da narração é o uso da terceira pessoa, pois refere-se a pessoas ou feitos não presentes. Em Dt 31,9-13, entre verbos explícitos e implícitos são encontrados 24 verbos, 14 estão conjugados na terceira pessoa, 4 na segunda pessoa e 6 verbos estão no infinitivo (sendo que 2 estão com sufixo de terceira pessoa). Há uma predominância quase que total no uso da terceira pessoa. ${ }^{144}$

Há também uma fórmula inicial na perícope, v. 9, “e escreveu Moisés esta

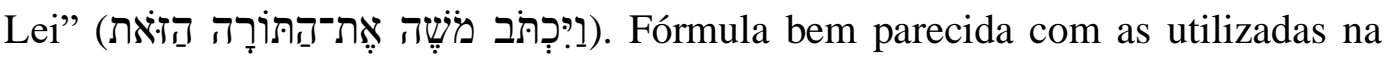
abertura dos quatro discursos proferidos por Moisés no livro de Dt. ${ }^{145}$ Quatro sentenças são colocadas na boca do narrador, em seguida é Moisés quem assume o discurso. De modo parecido, em Dt 31,9, Moisés entra em cena assumindo o discurso. Uma fórmula introdutória é uma estratégia usada pelo autor sagrado para iniciar um novo texto e é uma dinâmica marcante no livro de Deuteronômio.

Uma visão geral dos textos, precedente e subsequente, permite perceber que nos vv. 1-8 se encontram as palavras de Moisés dirigidas a Josué; nos vv. 9-13 estão palavras de Moisés dirigidas aos sacerdotes, filhos de Levi, e anciãos; nos vv. 14-18 muda-se o sujeito, YHWH é quem fala e suas palavras são dirigidas a Moisés e Josué. Há, por assim dizer, uma unidade em cada seção, permitindo a sua devida delimitação. Assim, o papel da Lei entregue aos sacerdotes encarregados da arca da aliança de YHWH - e aos anciãos em Dt 31,9-13 está entre duas falas marcadas pela presença de Moisés e Josué.

Fixando um olhar em Dt 31,9-13, percebe-se que o texto, aberto pela fórmula introdutória não encontra uma espécie de repouso, pois segue à fala de Moisés, uma ordem de YHWH: "Chama Josué, e apresentai-vos na Tenda de Reunião" (v. 14). Acontece, então, um salto para um novo discurso, onde YHWH assume a fala, fato que distingue bem a separação dos dois textos. Assim,

\footnotetext{
${ }_{144}^{145}$ Veja-se anexo 1.

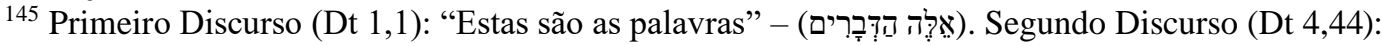

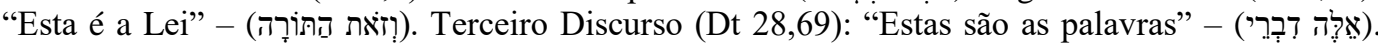

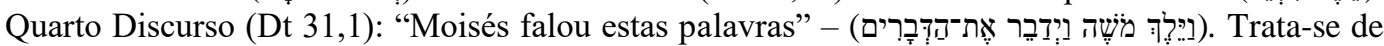
quatro sentenças nominais (sem verbo explícito) que geralmente começam com um pronome demonstrativo e são seguidas por um substantivo, o qual especifica e sintetiza o conteúdo principal (LÓPEZ, F. G., O Pentateuco, p. 240).
} 
curiosamente, os vv. 9-13 são retomados nos vv. 24-29 como uma forma de concretizar ou de reforçar a ordem. Dt 31,30 enquanto conclui o que precede, serve de introdução para o cântico de Moisés (Dt 32,1-43). No final, o narrador toma a palavra e enfatiza a figura de Josué ao lado de Moisés (v. 44). ${ }^{146}$

\subsection{2. \\ Quanto à unidade}

\section{a) Do ponto de vista dos períodos}

Percebe-se que Dt 31,9-13 está articulado através de três períodos compostos, que englobam os seguintes versículos: $1^{\circ}$ período v. $9,2^{\circ}$ período vv. 10-11, $3^{\circ}$ período vv. 12-13.

O primeiro período é iniciado com uma oração principal que se encontra no v. 9a: "E escreveu Moisés esta Lei”. Na sequência, estão orações coordenadas, que podem ser classificadas como sindéticas aditivas, pois estão marcadas pela conjunção "e" (waw), denotando acréscimo de informações. Estas orações estão associadas às ações e movimentos de Moisés e abrangem todo o v. 9.

O segundo período é composto de uma oração principal, localizada no início do v. 10, "e ordenou-lhes Moisés", logo a seguir vê-se, na segmentação $10 \mathrm{bc}$, que são orações subordinadas objetivas diretas, uma está sinalizada pelo verbo no

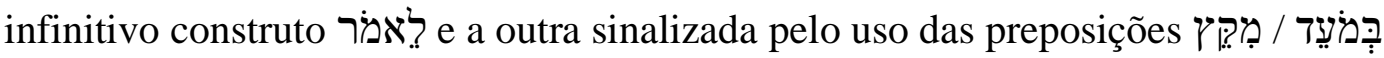
/ Nọִ. No v. 11a, se tem a presença de um verbo no infinitivo construído com uma

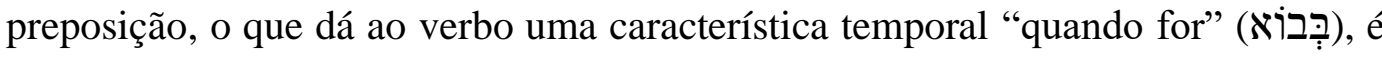
um verbo de movimento. Se tem, então, mais uma oração subordinada, agora com valor adverbial de tempo. Em seguida, no v. 11b, aparece outro verbo no infinitivo construto לרָָאוֹת , caracterizando outra oração subordinada, expressando finalidade, pois todo o Israel deveria ir, no período da festa dos tabernáculos "para se apresentar" diante de YHWH, a oração se trata de uma adverbial final.

\footnotetext{
${ }^{146}$ Dt 31,1-29 parece compósito. Contudo, do ponto de vista metodológico: "Esse fato indica que houve uma vontade e uma mão de escritor que juntaram essas diversas unidades" (SIMIANYOFRE, H., et. al. Metodologia do Antigo Testamento, p. 91).
} 
$\mathrm{O}$ v. 11c oferece um dado relevante pois YHWH é que escolhe o local de culto. A proposição é nominal, pois quer enfatizar o "lugar" de culto. ${ }^{147} \mathrm{O}$ segundo período tem duas orações principais, uma está localizada no segmento v. 10a e a outra no v. 11d, de onde se pode extrair, de forma resumida, o ponto alto do assunto abordado: "E ordenou-lhes Moisés: proclamarás esta Lei”. Esta é a mensagem culminante estabelecida dentro desse período.

Uma grande atenção deve ser dada ao fato do verbo "proclamarás" ser apresentado no singular (v. 11d). O sujeito do verbo está implícito: "tu", segunda pessoa do singular, o que leva a entender que se trata de uma única pessoa, e esta pessoa está bem próxima a Moisés. É possível que se trate de Josué, já que ele está presente no discurso precedente (Dt 31,1-8) e no subsequente (Dt 31, 14-18) e estará na linha de frente, como novo líder de Israel, isto lhe confere a autoridade e o dever de proclamar a Lei.

O terceiro período é mais extenso, pois é composto por diversas orações.

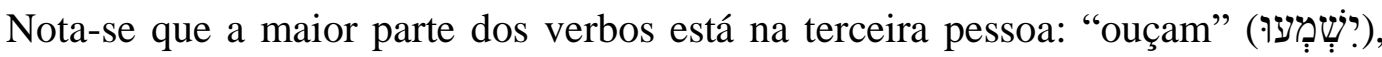

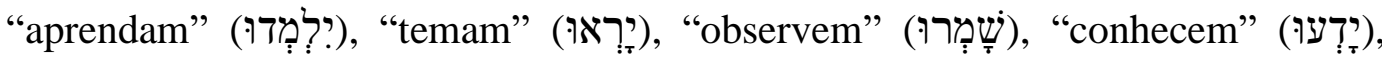
caracterizando o discurso narrativo.

Enfim, encontram-se alguns verbos no infinitivo construto: "cumprir"

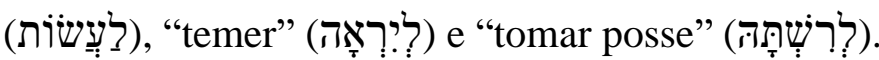

Os vv. 12-13 são compostos por diversas orações subordinadas, mas, também se tem a presença de orações coordenadas sindéticas aditivas. A oração principal que está no v. 12a e é governada por um imperativo “congrega" (הָקחהל), também funciona como sujeito dos verbos ouvir, aprender, temer, observar e cumprir: "o povo: os homens, as mulheres, as crianças e o teu estrangeiro". No v. 13a muda o sujeito, e a referência tem a ver com a segunda geração, a que nasceu no deserto: “os filhos deles” (בְנְיהֶ).

A partir desse ponto, a segunda geração vai ser o sujeito dos seguintes

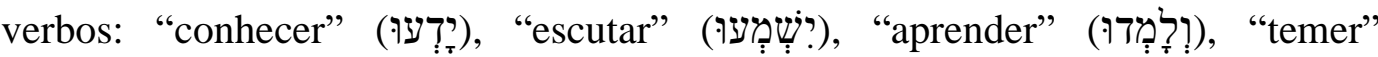

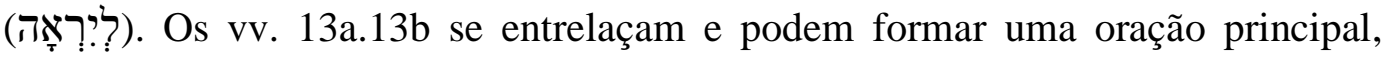

147 "E é possível que as leis sobre está centralização sejam acréscimos feitos no tempo de Ezequias, principalmente quando se diz 'entre todas as tribos' (Dt 12,5), 'numa de suas tribos' (Dt 12,14), isto é, o santuário agora em questão era somente o Templo de Jerusalém”" (STORNIOLO, I., Como Ler o Livro do Deuteronômio, p. 28). 


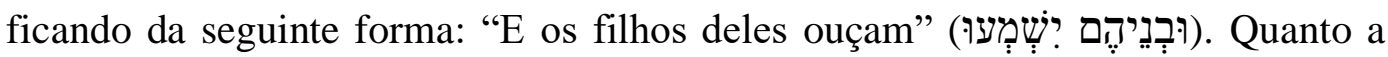

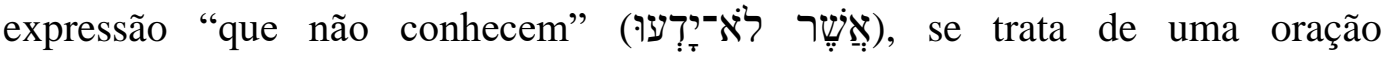
subordinada relativa apositiva.

No v. $13 \mathrm{c}$ se tem uma oração coordenada sindética aditiva e no v. 13d aparece uma oração subordinada adverbial temporal, iniciada com a expressão

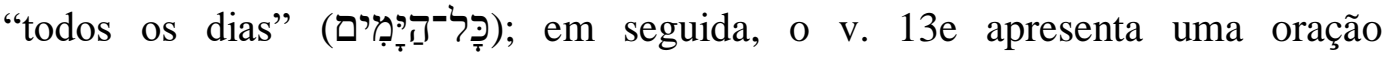
coordenada sindética explicativa e o v. 13f uma oração subordinada adverbial final, porque é esta a geração que vai atravessar o Jordão, tomar posse da terra prometida e deverá escutar e aprender a Lei, para que as palavras de YHWH tenham pleno cumprimento em suas vidas. ${ }^{148}$

Os verbos em sua totalidade são de ação e promovem a dinâmica do texto: tudo se direciona para o livro da Lei, o livro que garante a vida e as bênçãos, caso seja colocado em prática. Há proposições nominais, mas prevalecem as verbais. Em Dt 31,9-13, se encontram 14 proposições verbais e 11 proposições nominais.

No v. 11c, visto que a oração não começa com um verbo, pode-se pensar

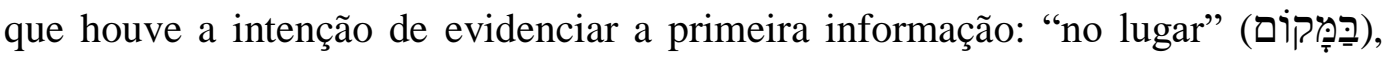
que aparece em primeiro plano nesta proposição nominal. Nota-se um eco com a noção típica do livro de Deuteronômio, quanto à escolha do futuro lugar de culto, visto que, pela narrativa, Israel ainda não entrou em Canaã. ${ }^{149}$

$\mathrm{Na}$ proposição nominal do v. 13f, uma partícula adverbial com he de direção, "para ali" (ש்ָָׁ), indica o local para o qual Israel se dirige, oferecendo precisão, pois fica do outro lado do Jordão. Neste último segmento, a ação está

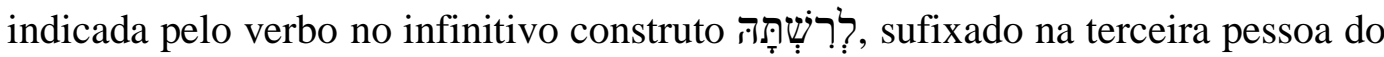
feminino singular, correspondendo ao objeto da conquista: a terra. A ideia de posse expressa-se por meio do sufixo que funciona como adjetivo possessivo.

148 ““E acontecerá que o Senhor, seu Deus, o levará à terra que havia prometido a seus pais - a Abraão, a Isaac e a Jacó - para dá-la a vocês'. O fato de a antiga promessa estar tão perto de ser cumprida causava não somente alegria, mas também seriedade diante da responsabilidade que a promessa impunha. Moisés expressa essa alegria descrevendo a copiosa abundância da terra que Deus lhes daria. Este seria o perigo que o povo enfrentaria ao entrar na terra e que Moisés estava preocupado. Na terra, as próprias riquezas e excelências poderiam levar o povo a uma atitude de esquecimento que seria desastrosa" (CRAIGIE, P. C., Comentários do Antigo Testamento: Deuteronômio, p. 169-170).

149 “YHWH, Deus único (Dt 6,4), poderá ser legitimamente adorado em apenas um santuário, no lugar 'escolhido pelo Senhor, para nele fazer habitar o seu nome' (Dt 12,11 entre outros). Trata-se, quanto ao lugar não citado nos textos, de Jerusalém" (GRADL, F.; STENDEBACH, F. J., Israel e seu Deus, p. 41). 


\section{b) Do ponto de vista da lógica narrativa}

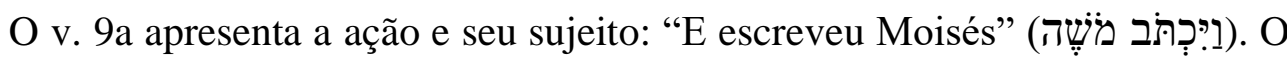
mesmo sujeito, é repetido pelo nome no v. 10a. Ao lado do sujeito, que se mantém presente no texto pelo discurso que faz (vv. 10c-13f), o objeto direto presente na locução, "esta Lei" (הַתוֹרָה הזּאת) foi usado mais duas vezes nos vv. 11d e 12g.

YHWH e Israel, unidos pela Lei escrita por Moisés (v. 9a) e pela posse da terra (v. 13f), são os motivos da fala de Moisés aos seus destinatários: os sacerdotes (v. 9b) e os anciãos (v. 9d). O Tetragrama Sagrado ירוז: foi usado

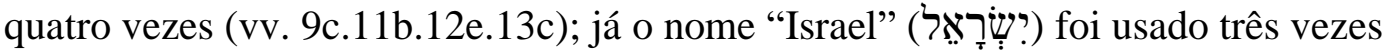
(vv. 9d.11a.11e). Os sacerdotes são qualificados pela tribo à qual pertencem, “filhos de Levi” (v. 9b), já os anciãos são designados pelo povo, "Israel” (v. 9d).

Aos sacerdotes e aos anciãos cabem realizar ações específicas: proclamar a Lei, a cada sete anos, a fim de instruir Israel, assumido em sua totalidade: homens, mulheres, crianças e estrangeiros (v. 12a). A finalidade principal que advém da celebração é "temer" YHWH, verbo que se repete duas vezes (vv. 12e.13c). Esta ação aparece como derivada de outras duas: ouvir (v. 12c. 13b) e aprender (v. 12d.13c). Assim, transparece a consequência: "vivereis sobre a terra" (v. 13d).

O pronome demonstrativo "este" (הזּאת), precedido de artigo, assumindo valor de adjetivo atributivo. Por este se qualificou o substantivo determinado por artigo, "a Torá" (הַתְic), indicando que é a base de todo o discurso de Moisés, razão pela qual recebeu ênfase pelas repetições indiretas ao longo do v. 12, pois seria o complemento de cada verbo no infinitivo construto.

No tocante às ações, dentro do discurso de Moisés (vv. 10c-13f), percebe-se a noção de futuro em função de um momento celebrativo específico (v. 10c). O uso do yiqtol (v. 11cd) e do estado construto fundamentam essa prerrogativa temporal. Em particular, a forma verbal no estado construto (vv. 10b.11a.11b.12g. 13c.13f) aparece como uma marca do conteúdo que Moisés desenvolve.

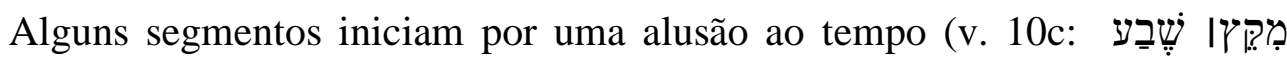

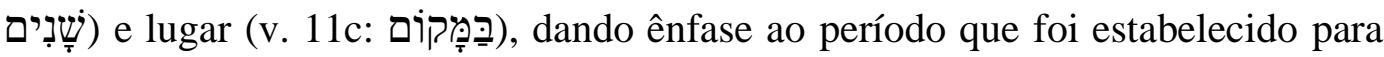
leitura da Lei e o lugar onde deverá ser, efetivamente, realizada esta leitura: "por ocasião do ano da remissão, na festa dos tabernáculos" (10c). A Lei, colocada em prática, “todos os dias" (v. 13d), servirá como garantia de permanência na terra. 
Uma formulação com valor adverbial, "para ali" (v. 13f), reforça o sentido da posse da terra. É o lugar onde a Lei, escrita por Moisés, dada aos sacerdotes e aos anciãos, será lida a cada sete anos diante de todo o povo, numa festa específica, "tabernáculos", a fim de que septenariamente seja proclamada, conhecida e vivida integralmente no cotidiano da vida do povo estabelecido na terra. Revela-se a correspondência entre a leitura a cada sete anos e o que Israel poderá experimentar diariamente: "vivereis sobre a terra" (v. 13d).

Em síntese, a lógica interna de Dt 31,9-13 permite perceber, claramente, o tema enfatizado na narrativa: “esta Lei” (הַתּוֹרָה הַזּאת). Todos devem ouvir "esta Lei” (vv. 12c.13b), aprender "esta Lei” (v. 12d), observar “esta Lei” (12f). Assim, o discurso de Moisés, em tom exortativo, confere unidade à perícope. 150

\section{c) Do ponto de vista estilístico}

Dt 31,9-13 apresenta recursos estilísticos. A conjunção "e" (waw) aparece em várias orações coordenadas sindéticas aditivas (vv. 9b.9d.12e.12f.13c). Notam-se, ainda, outras funções para o waw: ligar ações e produzir alteração no sentido temporal. Além disso, o waw ocorre nove vezes, de um total de 12 usos, abrindo proposições. As maiores incidências ocorrem nos vv. 9.12.13.

A presença do substantivo "todo/todos/toda/todas" (כָָּּ) mostra que as determinações de YHWH exigem a totalidade do ser: "todos" os anciãos foram informados da responsabilidade de resguardar a Lei (v. 9d); "todo" o povo de Israel deveria se apresentar diante de YHWH (v. 11a) e foi determinado que ninguém poderá estar ausente da solenidade voltada para a instrução através da leitura da Lei e, novamente, é reafirmado que a Lei deverá ser proclamada diante de "todo" o Israel (v. 11e), para que aprendam e possam cumprir "todas" as palavras (v. 12g), em "todos" os dias de sua vida (v. 13d). Moisés, que escreve "esta Lei" e é porta-voz de YHWH, deixa claro que Israel deve se entregar totalmente para possuir integralmente, todos os dias, a terra que está além do Jordão. A base recai sobre o conhecimento da Lei pela qual se cumpre a vontade de YHWH.

\footnotetext{
150 “A recitação pública periódica do documento pactual deveria acontecer no futuro, em intervalos de sete anos. No ano sabático, durante a festa dos tabernáculos, a lei deveria ser recitada aos ouvidos de todo o Israel. Sobre a festa dos tabernáculos, veja Dt 16,13-15. 'No lugar que ele escolher' (Dt 31,11; 16,15), a cerimônia seria realizada no santuário, onde as tábuas/pedras da aliança e a lei escrita (Dt 31,9) estariam guardadas" (CRAIGIE, P. C., Comentários do Antigo Testamento: Deuteronômio, p. 359).
} 
Outro recurso estilístico usado no texto seria o substantivo comum plural,

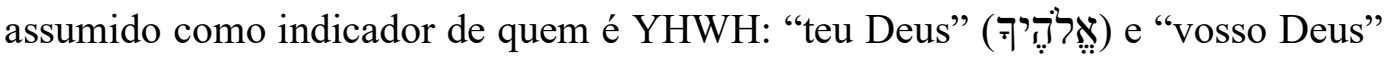
(אֶלה cumprimento das ordens dadas por Moisés aos sacerdotes e aos anciãos. ${ }^{152}$

Outro aspecto que se pode considerar e que perpassa praticamente todo o livro de Deuteronômio são as seções tu/vós. As seções "vós" correspondem as narrações históricas e se referem diretamente à geração do Horeb/Sinai, os pais, em contrapartida as seções "tu" são preferencialmente parenéticas e estão destinadas à geração da conquista, os filhos. ${ }^{153}$

Em síntese se tem uma perícope bastante despojada, simples, de fácil leitura, que comunica seus propósitos de forma esclarecedora e precisa. No desenrolar do enredo se estabelece uma conexão entre os três períodos indicados, que em grande parte é formado por orações subordinadas; configuradas uma com as outras de forma progressiva, onde o sujeito Moisés, pelo seu ponto de partida e desenvolvimento do discurso, alcança o seu ponto final. Todos os envolvidos, sacerdotes, anciãos, "Josué" e todo o povo, sabem perfeitamente o que deve ser feito e por qual razão deve ser feito.

Diante as considerações, acima elaboradas, pode-se afirmar que Dt 31,9-13 é um texto bem articulado e que pode ser considerado unitário, pois possui um tema devidamente organizado, segundo uma lógica interna. ${ }^{154}$ No seu conjunto, Dt 31,9-13 foi aberto pelo narrador (vv. 9-10b) e prosseguiu, sem problemas, com a fala de Moisés (vv. 10c-13f). Desse modo, compreende-se a dinâmica que abriu o livro, onde a fala do narrador (Dt 1,1-5) ambientou o primeiro discurso (Dt 1,64,40), e mostrou o valor do último dia da vida de Moisés. ${ }^{155}$

\footnotetext{
${ }^{151}$ CHAMPLIN, R. N., O Antigo Testamento Interpretado: Versículo por versículo, p. 10.

${ }^{152} \mathrm{O}$ nome divino, no livro de Deuteronômio, é citado mais de trezentas vezes, o que mostra a importância de exaltar o Deus de Israel (HOFF, P., O Pentateuco, p. 260).

${ }^{153}$ Segundo LÓPEZ, F. G. (El Deuteronomio - una ley predicada, p. 19-20): "Para se entender essa mudança de número singular/plural, que certamente não é fruto do acaso, provavelmente a sua explicação deve ser procurada no processo de formação dos textos. Como regra geral, se pode afirmar que as seções parenéticas e legislativas no singular correspondem ao Deuteronômio primitivo (a maior parte dos capítulos 6-28), e que as seções históricas e outras passagens no plural foram acrescentadas posteriormente (boa parte dos caps. 1-5; 9,7-10.11; 29-34)".

${ }^{154}$ SIMIAN-YOFRE, H., et. al. Metodologia do Antigo Testamento, p. 84.

${ }^{155}$ SKA, J. L., "I nostri padri ci hanno raccontato", p. 24. Il Deuteronomio contiene gli ultimi discorsi di Mosè, pronunciati l'ultimo giorno della sua vita (Dt 1,3; 32,48-52; 34,5). II tempo raccontato è quello di una giornata e il tempo raccontante quello dei 34 capitoli del Deuteronomio. Si tratta del «giorno più lungo» di tutta la permanenza nel deserto.
} 


\subsection{3. \\ Quanto à organização}

Dt 31,9-13, então, pode ser organizado a partir de três períodos compostos. Seguindo a sua lógica interna: o v. 9 contém a fala do narrador; os vv. 10-11 contextualizam o quando e o que deve ser feito; os vv. 12-13, além de ampliar os vv. 10-11, apresentam o para quem, e o efeito que se espera da ação.

O segmento 9a é uma oração principal iniciada por um verbo no wayyiqtol:

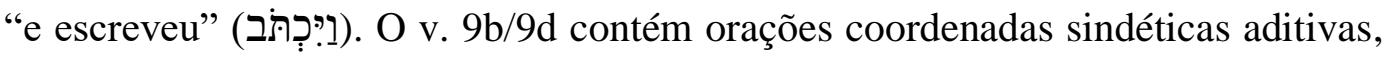
que apesar de serem "independentes", então ligadas pelo waw consecutivo. O segmento 9c é um aposto que complementa a informação dada no v. 9b.

O segundo período é iniciado pelos segmentos v.10ab, que correspondem ainda à fala do narrador, agora introduzindo o discurso direto de Moisés, marcado

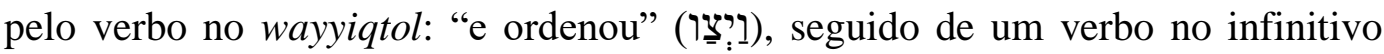
construto, "dizendo" (לאמלר), que abre o discurso direto de Moisés. ${ }^{156}$

No v. 10c a primeira oração é preposicional (Ỵִִ̣), e é seguida por um duplo aposto que situa o sentido do tempo e do acontecimento de índole cultual.

Nos segmentos $11 \mathrm{ab}$, os dois verbos estão no infinitivo: "quando for"

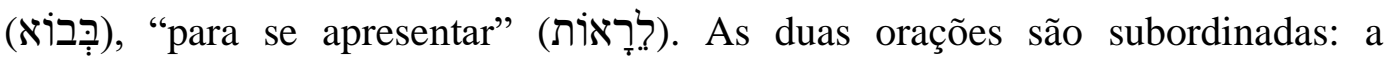
primeira, é adverbial temporal; a segunda, uma adverbial final. Na sequência, o segmento 11c complementa o "quanto" e o "quê", com uma referência a um "lugar" indeterminado (范), seguido de uma partícula relativa que introduz

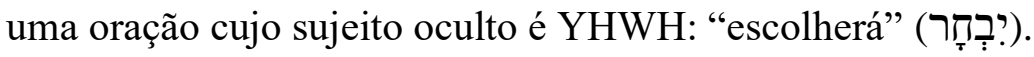

Uma vez que as informações necessárias foram oferecidas por Moisés, segue-se uma ação (v. 11d), cujo sujeito está na segunda pessoa do masculino

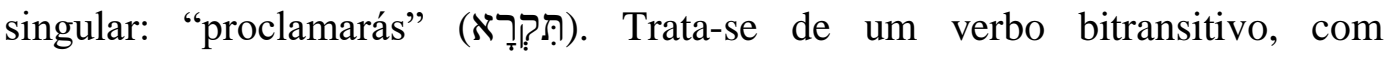
complemento direto: "esta Lei”" (הַתּוֹרָה הַזּאת), e indireto (v. 11e): "diante de todo

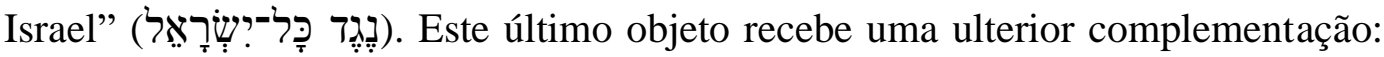

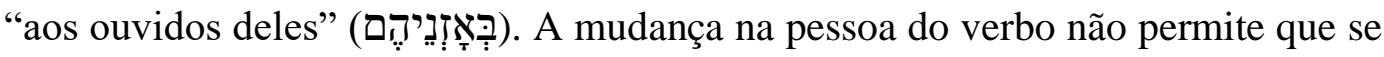
pense, a priori, que se trata dos sacerdotes e anciãos indicados no v. 9b/9d.

\footnotetext{
$156 \mathrm{O}$ infinitivo construto לִ לאמר extremamente frequente e amplamente usado na frase que introduz o discurso direto e serve para suprir a ausência do sinal de pontuação (JOÜON, P.; MURAOKA, T., Gramática Del Hebreo Bíblico, p. 461).
} 
O terceiro período aberto no segmento $12 \mathrm{a}$, contém uma expressa ordem de Moisés a um sujeito que também, como no v. 11d, está na segunda pessoa do singular: "congrega" (הָקהָל). O objeto direto dessa ação, marcado pela partícula אֶ, é um coletivo determinado: “o povo" (הָעָָ), que recebe um desdobramento

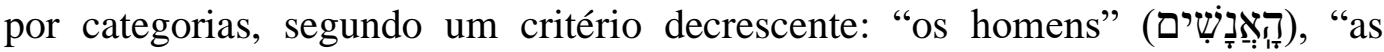

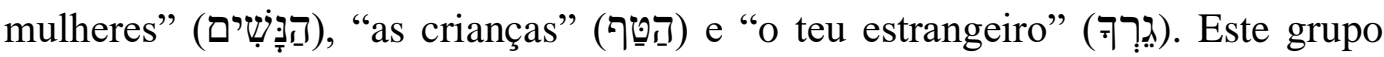
destinatário da ação por meio de uma oração relativa com verbo implícito, se encontra devidamente localizado e que tem a ver com o local determinado por

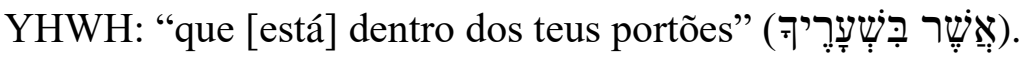

Os segmentos 12cd, contêm orações subordinadas finais. A mesma

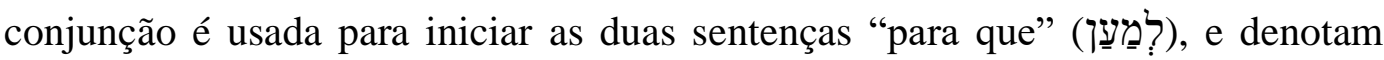
este particular, dando ênfase às proposições. O sujeito, pela pessoa verbal, corresponde às categorias de pessoas do segmento anterior; deverão se reunir com

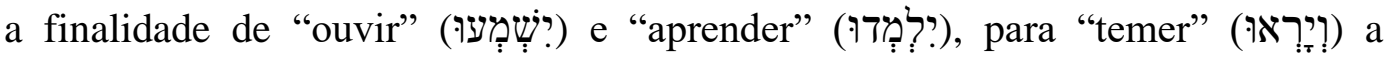
"YHWH, o vosso Deus" (v. 12e).

Tendo como ponto de partida a Lei escrita por Moisés (v. 9a), pode-se aceitar que os segmentos $12 \mathrm{fg}$, são o ápice desse período. A Lei, posta por escrito, lida, escutada, e obedecida é o ponto principal da mensagem e finalidade das

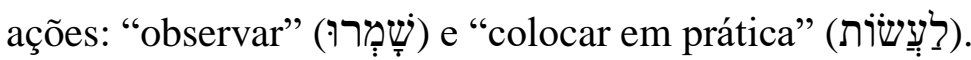

A presença da "criança", como categoria pessoal no final do v. 12a recebe um sentido pedagógico, em relação aos pais, no sujeito plural da proposição nominal do segmento 13a: “e os filhos deles” (וּجְנִיהֶ). É o sujeito tanto da frase

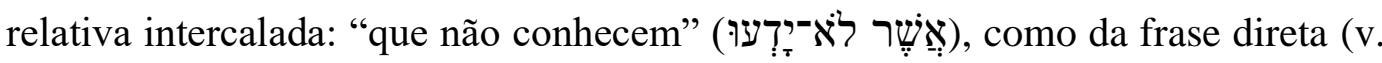

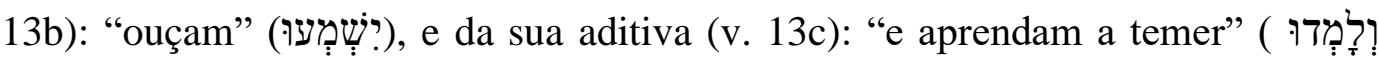

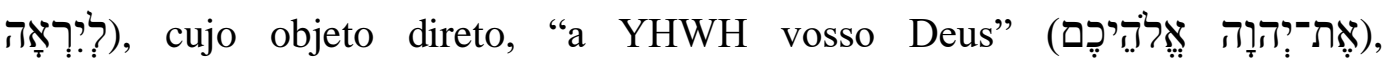
corresponde, perfeitamente, à finalidade desejada no v. 12e.

Pelo aṭnāh da indicação massorética (v. 13c), no segmento $13 \mathrm{~d}$ se encontra

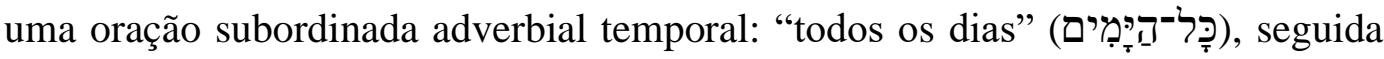
de uma partícula relativa "que" (พָ), que precede a oração nominal: "vós

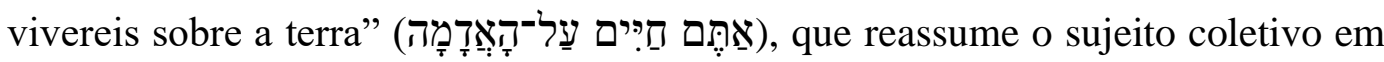
suas categorias de pessoas do v. 12a. 
A razão, ou justa motivação, para tudo o que foi dito por Moisés aparece nos dois últimos segmentos. No v. 13e, encontra-se uma oração formalmente paralela ao v. 13d: partícula relativa, pronome pessoal, verbo e complemento,

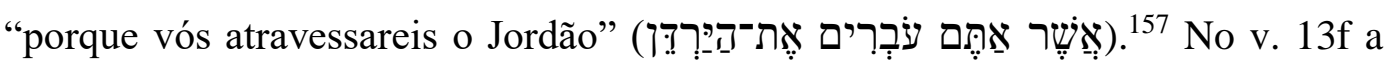
proposição é nominal, iniciada por uma formulação com valor adverbial "para ali"

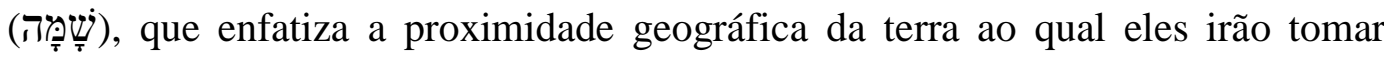
posse e viver. A ênfase é entendida por dois motivos: o advérbio encontra-se em primeira posição na frase e, também, por conter o he de direção, indicando a terra.

Considera-se, portanto, que Dt 31,9-13 está devidamente organizado e flui textualmente. As únicas "tensões" se encontram nas locuções, "teu Deus" (v. 11b) e "vosso Deus" (vv. 12e.13c), bem como no sujeito no singular dos verbos, "proclamarás" (v. 11d) e "congrega" (v. 12a), que parecem não se aplicar nem aos sacerdotes (v. 9b) nem aos anciãos (v. 9d), mas como se supõe, na exigência de comprovação, poderiam estar dirigidos à pessoa de Josué que é uma figura relevante em Dt 31,1-8.14-18. Assim sendo, pode-se proceder com a apresentação da estrutura e do respectivo gênero literário.

\section{4. \\ Estrutura e gênero literário}

\subsection{1.}

\section{Quanto à estrutura}

O contexto literário de Dt 31,1-30 apresenta uma sequência que pode ser visualizada de maneira concêntrica em torno de um centro que consiste no diálogo entre YHWH e Moisés. A unidade pode ser articulada em cinco momentos. ${ }^{158}$

A - Dt 31,1-8: Moisés fala ao povo e a Josué.

B - Dt 31,9-13: Moisés fala aos sacerdotes e anciãos.

C - Dt 31,14-23: YHWH fala a Moisés sobre a sucessão e o cântico.

B' - Dt 31,24-29: Moisés fala aos levitas.

A' - Dt 31,30: Moisés, tendo Josué ao seu lado, falou ao povo o cântico.

\footnotetext{
157 A discussão sobre a opção de tradução da partícula relativa (⿻丷ֶׁ) por uma conjunção explicativa, "porque", será feita no comentário.

${ }^{158}$ PAGANINI, S., Deuteronômio, p. 422.
} 
Dentro da lógica dessa unidade, o segundo discurso se refere a fala de Moisés aos sacerdotes e anciãos. Percebe-se que em Dt 31,9-13 uma sequência, também concêntrica, aparece nos vv. 9-10a:

A - "E escreveu Moisés esta Lei” (v. 9a).

B - "e a deu aos sacerdotes, filhos de Levi" (v. 9b).

C - "os que levam a arca da aliança de YHWH” (v. 9c).

B' - "e [deu] a todos os anciãos de Israel” (v. 9d).

A' - "E ordenou-lhes Moisés" (v. 10a).

Entre A e A' encontram-se os destinatários que têm a ver tanto com a Lei escrita como com a ordem que recebem em função dela. Moisés escreve a Lei e ordena aos sacerdotes e anciãos, aos que tinham a obrigação de cuidar e zelar pela Lei e pela instrução do povo. Esses são os guardiões da Lei, responsáveis pela arca da aliança, pelo livro da Lei e pelo seu ensinamento ao povo.

A seguir, nos vv. 10b-11e, encontra-se outra formulação concêntrica que diz respeito à primeira parte da ordem de Moisés:

A - "Dizendo" (v. 10b).

B - "Ao final de sete anos, por ocasião do ano da remissão, na festa dos tabernáculos (v. 10c).

C - "quando for todo o Israel (v. 11a).

D - "para se apresentar diante de YHWH, teu Deus" (v. 11b).

C" - "no lugar que (YHWH) escolherá" (v. 11c).

B' - "proclamarás esta Lei diante de todo o Israel” (v. 11d).

A' - "aos ouvidos deles" (v. 11e).

A nova fala de Moisés é introduzida pelo narrador, "dizendo" (A), e tem um destino certo, "aos ouvidos deles" (A'). A seguir, está o quando (B) e o que deve ser feito na ocasião (B'). Israel, quando for (C), tem um destino certo (C'). Tudo gira em torno do motivo previsto na Lei (D).

Ao se analisar a segunda parte da ordem de Moisés, a sequência verbal permite perceber novo encadeamento concêntrico de ações. Moisés, primeiramente, relaciona todos os que deveriam estar presentes para escutar a leitura da Lei e, a seguir, enfatiza a Lei que deve ser observada através de expressões verbais às ações pertinentes. 
A - "para que ouçam" (v. 12c).

B - "e para que aprendam" (v. 12d).

C - "e temam a YHWH, o vosso Deus" (v. 12e).

D - “e observem" (v. 12f).

E - "para cumprir todas as palavras desta Lei” (v. 12g).

D' - “e os filhos deles, que não conhecem, ouçam” (v. 13ab),

$\mathrm{C}^{\prime}$ - "e aprendam a temer a YHWH, vosso Deus" (v. 13c).

B' - "todos os dias que vós vivereis sobre a terra” (v. 13d).

A' - "porque vós atravessareis o Jordão, para ali, tomar posse dela” (v. 13ef)

Através dessas estruturas, a fala de Moisés, isto é, a sua ordem, pode ser subdividida em duas partes. A primeira estabelece todos os pontos relativos ao tempo, a ocasião, ao tipo de festividade e a determinação do lugar que será escolhido por YHWH para se realizar tal evento. Já a segunda é introduzida com um imperativo e está relacionada com a convocação das pessoas que deverão estar presentes nesta solenidade para ouvir a leitura da Lei. Em seguida, Moisés fala com autoridade, usando uma série de verbos, exaltando a finalidade e a função da Lei: ensinar a nova geração, que nasceu no deserto, para que não se repita o erro de obstinação e desobediência cometidos por seus pais que foram libertos do Egito e selaram a aliança com YHWH no Horeb/Sinai.

Dentro dessa lógica estrutural, Dt 31,9-13 é descrito e apresentado pelos meios necessários para as futuras gerações (ouvir, aprender e cumprir as palavras contidas no livro da Lei), uma vez que tomem posse da terra, para que observem a aliança que foi renovada na terra de Moab (Dt 28,69-30,20). ${ }^{159}$

A dinâmica literária do livro de Deuteronômio atesta o seu estilo enfático e retórico. Muitas frases se repetem: "Recorda que fostes escravo na terra do Egito"; 160 "sem te desviares para a direita ou para a esquerda"; 161 "tomar posse da terra"; 162 "YHWH, Deus dos teus/vossos pais"; 163 "terra onde mana leite e mel"; 164 “Todo Israel”. ${ }^{165}$ Admite-se que: "o tom homilético é encontrado até

\footnotetext{
159 "Esta primeira notícia da colocação por escrito da Torá é fundamental no contexto da hermenêutica jurídica do Deuteronômio" (PAGANINI, S., Deuteronomio, p. 422).

${ }^{160}$ Dt 5,$15 ; 10,19 ; 15,15 ; 16,12 ; 24,18.22$.

${ }^{161}$ Dt 2,$27 ; 5,32 ; 17,11.20 ; 28,14$.

${ }^{162}$ Dt 2,$31 ; 3,28 ; 4,1.5 .14 ; 6,1 ; 9,5.23 ; 10,11 ; 11,11.29 ; 23,21$.

${ }^{163}$ Dt $1,11.21 ; 4,1 ; 12,1 ; 26,7 ; 27,3$.

${ }^{164}$ Dt 6,$3 ; 11,9 ; 26,9.15 ; 27,3 ; 31,20$.
} 
mesmo no código legislativo (Dt $12-26^{*}$ ), em claro contraste com o estilo dos outros códigos hebraicos". 166

Certas ideias teológicas dominantes, como por exemplo, um único local de culto escolhido por $\mathrm{YHWH}^{167}$ ou ainda, a terra que $\mathrm{YHWH}$, teu Deus, te dará como herança, ${ }^{168}$ são ideias frequentemente repetidas, com uma finalidade pedagógica, a fim de que sejam fixadas, apreendidas e vividas. Estas são algumas características que envolvem a natureza didática deste livro. Apesar de bastante peculiar, o estilo retórico reflete certa influência profético-sacerdotal. ${ }^{169}$

O arranjo estrutural concêntrico de Dt 31,9-13 oferece a pista para o tema discursivo que dá unidade à perícope: a proclamação da Lei a cada sete anos. A fala introdutória do narrador (vv. 9-10b), e a fala de Moisés, em tom exortativo, são as partes que compõem o texto. O objetivo é instruir os filhos de Israel nas leis de YHWH em função da conquista da terra e das bênçãos que fluirão em uma vida de paz e segurança, se essas leis forem devidamente cumpridas.

Considerando a fala do narrador como uma introdução ao discurso direto de Moisés (vv. 9-10b), o mesmo, descreve as ações correspondentes ao protagonista da fala, que: "escreveu esta Lei”, “deu aos sacerdotes e anciãos" e "ordenou-lhes", o discurso de Moisés que tem como principais interlocutores os sacerdotes, filhos de Levi e os anciãos, cujo objeto principal é a Lei a ser comunicada.

Este discurso trata-se de uma extensa ordem que percorre todo o restante do texto e vai do v. 10c até o final do v. 13 , que, por sua vez, pode ser seccionado em duas subpartes. A primeira subparte corresponde aos detalhes e determinações sobre a solenidade para a leitura da Lei. As informações são precisas quanto ao tempo, ao lugar e para quem. A fala de Moisés não deixa dúvidas. A segunda subparte corresponde à exigência de congregar o povo em sua totalidade, incluindo ainda o "teu estrangeiro". Para este grande evento existe clareza quanto à finalidade em função da vida na terra que está para ser conquistada além do Jordão.

\footnotetext{
${ }^{165}$ Dt 1,$1 ; 13,12 ; 18,6 ; 27,9 ; 31,1.7 .11 ; 32,45 ; 34,12$.

${ }^{166}$ McKENZIE, J. L., Deuteronômio. In: Dicionário Bíblico, p. 233.

${ }^{167}$ Dt $12,5.11 .14 .18 ; 14,23.24 .25 ; 15,20 ; 16,6.11 .15 .16 ; 17,8.10 ; 18,6 ; 31,11$.

${ }^{168}$ Dt $1,20.25 ; 2,29 ; 3,20 ; 4,40 ; 8,10 ; 11,17.31 ; 12,10 ; 15,4.7 ; 16,20 ; 17,14 ; 18,9 ; 19,2-3.10 .14$; 21,$1 ; 24,4 ; 26,1 ; 27,2-3 ; 28,8$.

169 "Tendências retóricas e preocupações com o culto e com a religião interior lembram as pregações dos sacerdotes levitas" (CHAMPLIN, R. N., O Antigo Testamento Interpretado: Versículo por versículo, p. 5).
} 
Além disso, a pretensão didático-pedagógica é clara: informar para formar, a fim de evitar que os filhos, que nasceram no deserto, pereçam como seus pais que desobedeceram e morreram sem entrar na terra e receber a sua herança. Desta forma, a sucessão de verbos, na fala de Moisés, são ações pontuais e não deixam dúvidas quanto ao que se espera das lideranças e dos liderados que, juntos, formam a propriedade de YHWH: ouvir, aprender, temer, observar, conhecer e se comportar de acordo. ${ }^{170}$ Pontos essenciais para que a geração entre, conquiste a terra, ensinando filhos e filhas a conhecer e a cumprir a vontade de YHWH.

O tom de Moisés não é de desespero, mas de despedida, pois a sua morte se aproxima. ${ }^{171}$ Ele se vai, mas deixa a herança do livro da Lei - "que ele mesmo mediou e escreveu" - aos cuidados dos que tinham plena condição de cumprir os desígnios de YHWH e ser exemplo para o povo: os filhos de Levi, sua tribo. Este livro seria para a nação de Israel uma forma de viver na amizade com YHWH e com os irmãos, mantendo a ordem e harmonia nos clãs e nas suas cidades. ${ }^{172}$

Quanto à organização temporal, a combinação dos verbos sugere uma interessante dinâmica. As ações e relações entre as personagens estão organizadas através de movimentos. Os primeiros verbos mostram as ações de Moisés, a seguir, são apresentadas proposições preposicionadas e dois verbos no infinitivo

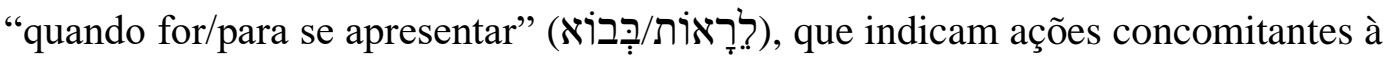

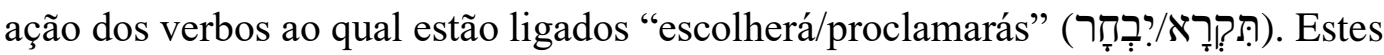
verbos, que sucedem o infinitivo, estão no yiqtol e, traduzidos pelo futuro, deixam claro que são ações a serem cumpridas após a entrada e tomada de posse da terra.

Dt 31,9-13 está formulado predominantemente na terceira pessoa. Isto produz o efeito da objetividade: narra-se como teria acontecido. Percebe-se, nisso, a força do testemunho que marca a transmissão da mensagem. ${ }^{173}$

\footnotetext{
${ }^{170}$ Segundo FERNANDES, L. A.: "O conhecimento determina o comportamento" (FERNANDES, L. A.; GRENZER, M., Êxodo 15,22-18,27, p. 139).

171 "O primeiro dia do undécimo mês do ano 40 da saída do Egito (Dt 1,3) representa a moldura temporal que enquadra tudo o que é referido no livro e é testemunha, enfim, da morte do grande líder. Somando esse dia ao sucessivo mês de luto pela morte de Moisés $(34,8)$, completam-se os quarenta anos da permanência de Israel no deserto (como decretado por Deus em Nm 14,33-34). Portanto, todo um livro bíblico é dedicado a guardar a memória de um único dia: o último, memorável dia da vida do grande personagem" (GALVAGNO, G.; GIUNTOLI, F., Pentateuco, p. 109).

172 “A Torá, então, não é um fardo legalista; pelo contrário, é um presente de Deus. Ele diz ao seu povo como viver, porque ele o ama e se importa com o que é melhor para ele, não porque queiras negar-lhes prazer" (VOGT, P. T., Interpretação do Pentateuco, p. 78).

${ }^{173}$ ZABATIERO, J., Manual de Exegese, p. 75-76.
} 
Em síntese, Dt 31,9-13 por ser estruturado em três momentos. O primeiro, v. 9, revela a ação de Moisés que fundamentará o que se segue. O segundo, estabelece todos os pontos relativos às determinações de YHWH em relação a Israel (vv. 10-11). O terceiro introduzido por um imperativo a um sujeito na segunda pessoa do singular tem a ver com a convocação das pessoas que deverão estar presentes nesta solenidade para escutar a leitura da Lei (v. 12ab). Moisés fala com autoridade; a série de verbos exaltam a finalidade e a função da Lei: ensinar a nova geração que nasceu no deserto e que passará a viver na terra além do Jordão (vv. 12c-13f). Um "novo Israel”, instruído e capacitado para viver na presença de YHWH que o libertou da casa da escravidão, o manteve com vida no deserto e está para cumprir a promessa da entrada e da posse da terra.

A partir das considerações acima feitas, Dt 31,9-13 pode ser apresentado a partir de três ações: escrever, ambientar e congregar:

\section{A. O livro da Lei: escrito para ser transmitido (v. 9)}

1. Moisés escreve o que YHWH ordena (v. 9a)

2. Entrega aos sacerdotes (v. 9bc)

3. E aos anciãos (v. 9d)

\section{B. Moisés ambienta a execução da ordem (vv. 10-11)}

1. A ordem é dada aos destinatários (v.10ab)

2. O tempo e ocasião para a leitura da Lei (v. 10c)

3. A escolha do lugar (v. 11abc)

4. A Lei deverá ser lida para todo o Israel (v. 11de)

C. Ordem abrangente dada por Moisés (vv. 12-13)

1. Congregar Israel com uma finalidade específica (v. 12ab)

2. Para ouvir a Lei e aprender a temer a YHWH (v. 12cde)

3. Para observar a Lei (v. 12f)

4. Para colocar em prática todas as palavras da Lei (v. 12g)

5. Para que as futuras gerações conheçam a Lei (v. 13abc)

6. Para praticar a Lei todos os dias da vida sobre a terra (v. 13d)

7. Para tomar posse da terra prometida (v. 13ef)

Por essa lógica, Dt 31,9-13 revela o teor jurídico-religioso pautado no livro da Lei, cuja função pedagógica mira as futuras gerações, pois uma geração deve narrar para a outra os feitos de YHWH, a fim de conhecer e cumprir a sua vontade. Isto implica na formação integral de Israel. Homens e mulheres adultos 
devem garantir a educação das crianças. É preciso ouvir e assimilar, desde cedo, a Lei de YHWH para, ao assumi-la pessoalmente, cada indivíduo seja responsável por seus atos. Isto pode garantir a sua eficácia na vida de cada membro do povo.

\subsection{2. \\ Quanto ao gênero literário}

No livro de Deuteronômio se encontram três elementos fundamentais: leis, narrativas e exortações. As leis apelam ao bom senso e ao sentimento que questiona diretamente a consciência. As narrativas falam do passado, mas dirigem-se ao presente em vista de formar uma consciência histórica que constrói o futuro. As exortações se dirigem à liberdade e sugerem uma tomada de decisão imediata. ${ }^{174}$

Dt 31,9-13 tem traços discursivos em tom persuasivo-exortativo. Isto corresponde à dinâmica do livro de Deuteronômio: "uma lei pregada."175 A principal temática do livro é a Lei a ser conhecida e colocada em prática. ${ }^{176} \mathrm{Dt}$ 31,9-13, portanto, tem a ver com o corpo legislativo que se encontra em Dt 12 26*. A estratégia usada para inserir as leis numa trama narrativa é um aspecto característico do Pentateuco e em especial do livro de Deuteronômio. ${ }^{177}$

Segundo essa percepção, em Dt 31,9-13 estão presentes a referência ao livro da Lei, sob a narrativa e o discurso exortativo devidamente entrelaçados. Pode-se dizer que Dt 31,9-13 está formulado como um discurso parenético, pelo qual Moisés, em tom exortativo, discursou aos sacerdotes e aos anciãos. Aos responsáveis se entregou o livro da Lei, a fim de que, pela instrução exercida com autoridade do líder, se preocupem com o futuro de Israel. Essa preocupação revela, de certa forma, o vivo interesse de Moisés não ter agido em vão. Como um pai, Moisés não quer deixar seus filhos sem a sua bênção, isto é, a sua herança.

\footnotetext{
${ }^{174}$ STORNIOLO, I., Como Ler o Livro do Deuteronômio, p. 12.

${ }^{175}$ LÓPEZ, F. G., El Deuteronomio - una ley predicada, p. 13.

176 "Para os israelitas da antiguidade, o Pentateuco inteiro - inclusive as seções de narrativas - era considerado 'instrução' ou 'ensino' de como viver uma vida agradável a Deus” (VOGT, P. T., Interpretação do Pentateuco, p. 26).

177 “A partir de uma perspectiva canônica, a Torá é uma mescla de narrativa e lei; ambas percorrem juntas, formando uma "unidade"” (LÓPEZ, F. G., O Pentateuco, p. 16). A lei é um dos gêneros mais importantes encontrados no Pentateuco e o segundo maior gênero é a narrativa, que é também o gênero literário mais comum em toda a Bíblia (VOGT, P. T., Interpretação do Pentateuco, p. 47).
} 
Dt 31,9-13 é um discurso normativo e, portanto, enquadra-se, perfeitamente, na dinâmica do livro de Deuteronômio ("segunda Lei”/“cópia da Lei”), visto que a Lei já havia sido entregue e a aliança selada no Horeb/Sinai (Ex 19,1-Nm 10,10).

Dt 31,9-13 combina elementos narrativos, discursivos e exortativos, cuja preocupação é a recepção e a transmissão do livro da Lei, em função das bênçãos de YHWH. O clímax desse texto, marca um momento especial: a entrega do livro da Lei aos sacerdotes e anciãos. É o ponto alto da ajuda de Moisés ao "novo Israel”. Seu ensino é registrado para não ser esquecido e negligenciado.

Se o estilo do livro de Deuteronômio é exortativo, Dt 31,9-13 não foge à regra. De forma retórica, Moisés usa palavras destinadas a mover os seus interlocutores ao compromisso e obediência a YHWH. Todos os discursos de Moisés são uma tomada de decisão contra a idolatria, a injustiça, os privilégios, contra o agir em prol de seus próprios interesses, contra todo tipo de corrupção, enfim, contra toda forma de desobediência à vontade de YHWH. ${ }^{178}$

Desta forma, Dt 31,9-13 atesta que a Lei escrita por Moisés é um documento capaz de conduzir Israel não apenas para a terra além do Jordão, mas, em particular, a uma vida de obediência e compromisso com seu Criador, Libertador e grande Pedagogo. ${ }^{179}$ Dt 31,9-13 é um discurso narrativo em prosa com tom exortativo. ${ }^{180}$ YHWH, através de Moisés, ordena a proclamação e o ensino da sua Lei aos que estão para entrar na terra e estes aos que nela nascerão. O presente fundamenta-se no passado e, por sua vez, tem o dever de garantir o futuro das novas gerações.

\footnotetext{
178 “Assim, embora Deuteronômio, em sua presente forma, seja uma peça literária, é importante manter em mente a autodescrição do livro como sendo um relato de palavras que foram faladas" (CRAIGIE, P. C., Comentários do Antigo Testamento - Deuteronômio, p. 17).

179 "Deuteronômio, como obra acabada, é um registro literário de uma fala proferida (ou série de discursos) que recebeu a forma de um documento pactual" (CRAIGIE, P. C., Comentários do Antigo Testamento - Deuteronômio, p. 18).

180 "No capítulo 31 encontramos o último discurso de Moisés em prosa, pois tanto o cântico de Dt 32 quanto as bênçãos em Dt 33 são textos poéticos e como tal revestem-se de uma importância fundamental. As últimas palavras de Moisés ao povo de Israel proclamam a confiança na proximidade de YHWH e encorajando o povo a não temer" (PAGANINI, S., Deuteronômio, p. 425-426).
} 


\section{Comentário de Dt 31,9-13}

\section{1. \\ Seção A - O livro da Lei: escrito para ser transmitido (v. 9)}

\subsection{1. \\ Moisés escreve o que YHWH ordena (v. 9a)}

E escreveu Moisés esta Lei

Dt 31,9 fala do livro escrito por Moisés e consignado aos sacerdotes, filhos de Levi, e aos anciãos. A existência do livro é proposta em várias passagens; ${ }^{181}$ mas esta é, no livro de Deuteronômio, a primeira afirmação explícita que Moisés devia escrever. Não implica que ele escreva só nesse momento, mas consente de atribuir ao escrito um significado particular. Escrever imita a ação de YHWH no Horeb (Dt 5,22; 10,4) e o livro se torna o instrumento que permite superar a ausência que a morte iminente de Moisés vai deixar para o povo. ${ }^{182}$ Assim, a experiência do Horeb/Sinai é revivida por Moisés ao escrever o livro da Lei, do mesmo modo como YHWH havia escrito os Dez Mandamentos sobre as duas placas de pedra (Dt 4,13; 5,22; 9,10;10,2.4). ${ }^{183}$

Moisés escreve aquilo, que terá um papel decisivo na vida de Israel (Dt $31,9-13 ; 24-27 ; 32,45-47) .{ }^{184} \mathrm{Na}$ Lei estão contidas as diretrizes fundamentais pelas quais, este povo, será guiado, quando entrar e conquistar a terra prometida depois da morte de Moisés, sob a liderança de Josué. ${ }^{185}$

Esta Lei escrita, necessariamente, não se refere a todo o livro de Deuteronômio, mas, talvez, como uma referência a Dt 12-26*. Por meio dela, se quis indicar que Moisés quis deixar um documento escrito capaz de formar as

\footnotetext{
${ }^{181}$ Dt 17,18; 28,58.61; 29,19.20.26; 30,10; 31,24.26.

${ }^{182}$ GRILLI, M.; PEREGO, G.; SERAFINI, F., Deuteronomio, p. 347.

${ }^{183}$ WOODS. E. J., Tyndale Old Testamenty Commentaries, v. 5, p. 302.

184 “A palavra Torá, geralmente traduzida por 'lei' deriva da raiz 'ער ' que significa 'ensinar' (cf. 1 Rs 8,36 ) e pode também verter-se por 'instrução'. Seja como for, tem o vocabulário hebraico muito maior extensão que a nossa palavra lei, pois não só abrange estatutos e mandamentos (Dt 4,1-2), como ainda de modo geral toda a revelação divina. No presente caso refere-se aos códigos e, no Deuteronômio em geral, a toda ou parte da doutrina ensinada por Moisés. Neste livro, encontra-se apenas no singular, a provar que se trata de um todo único e não de uma simples coleção de leis" (MANLEY, G. T., Novo Comentário da Bíblia, p. 9).

${ }^{185}$ LÓPEZ, F. G., O Pentateuco, p. 229.
} 
futuras gerações. O verbo "escreveu" (כָתַב), atestado no AT, não tem sentido ambíguo. ${ }^{186}$ No contexto da Torá, o livro de Gênesis é o único livro que não apresenta alguma ocorrência.

A narrativa de Ex 2,5-10 permite-se pensar que Moisés fora educado em uma família egípcia - sabia ler e escrever - inclusive o seu nome é egípcio e significa "filho". ${ }^{187}$ Esta ligação especificamente afirmada de Moisés com a corte, mesmo que seja um adorno de saga, a tradição pôde insinuar a sua exposição vantajosa à cultura e ao saber egípcio, que proporcionaram a Moisés conhecimento e facilidade biculturais como egípcio e como israelita. ${ }^{188}$

Não há como se afirmar, categoricamente, a autoria de Moisés de algumas partes do livro de Deuteronômio. As referências contidas em Dt 31,9.22: "E escreveu Moisés esta Lei" / "E naquele mesmo dia Moisés escreveu este cântico", atestam um critério de autoridade. ${ }^{189}$ Interessante notar, que somente em Dt 31 se repete 4 vezes que Moisés escreveu a Lei (vv. 9.19.22.24).

Moisés escreve a Lei e isto traz uma nova posição para os israelitas, agora eles pertencem a um povo que tem as suas próprias Leis. Desta forma, Israel preparou-se para se tornar uma nação eleita por YHWH pelo dom da Lei e pela conquista de Canaã. ${ }^{190}$ Deus o escolheu e gradativamente, como um Pedagogo, se deu a conhecer e se revelou através de seu servo Moisés e da Lei. O povo precisava ser instruído no conhecimento de YHWH, da sua verdade e do seu amor. Um amor gratuito, mas que espera em resposta o mínimo que se pode dar: a gratidão que se reveste na obediência. ${ }^{191}$

\footnotetext{
${ }^{186}$ Segundo HARRIS, R. L., (כָּבת. In HARRIS, R. L.; ARCHER, G. L.; WALTKE, B. K. DITAT, p. 754-755): Algumas passagens atestam que Moisés escreveu num rolo a maldição de Deus sobre os amalequitas (Ex 17,14), mas o próprio Deus escreveu os Dez Mandamentos (Ex 31,18). Também se diz especificamente que Moisés escreveu o Livro da aliança (Ex 24,4), a legislação do Sinai (Ex 34,27), os nomes dos líderes das tribos (Nm 17,2-3;17-18), o itinerário percorrido no deserto ( $\mathrm{Nm} 33,2)$, as palavras da lei "num livro, até de todos acabar" (Dt 31,9.24.) e o último de seus cânticos (Dt 31,22.24).

${ }^{187}$ FREUD, S., O homem Moisés e a religião monoteísta, p. 36-38.

${ }^{188}$ GOTTWALD, N. K., Introdução Socioliterária à Bíblia Hebraica, p. 190.

${ }^{189}$ MANLEY, G. T., Novo Comentário da Bíblia, p. 77.

${ }^{190}$ SKA, J. L., O Antigo Testamento: Explicado aos que conhecem pouco, p.54.

${ }^{191} \mathrm{O}$ relacionamento entre YHWH e o povo se estabelece mediante um ato prévio de YHWH: a eleição, que está primeiramente fundamentado no amor de YHWH (Dt 4,37) e está garantida pelo juramento inquebrantável prestado diante dos pais (primeira geração). Assim Israel vai receber sua herança - a terra - não pelas suas capacidades ou méritos, mas graças a promessa de YHWH (SCHMIDT, W. H., Introdução ao Antigo Testamento, p.134).
} 
O sentido da futura esperança da revelação mosaica não é nada menos do que a presença de YHWH no meio de seu povo. Essa esperança de Israel tem o seu fundamento com as alianças do Senhor com Abraão e Israel. Moisés - o servo de YHWH, o intercessor, o mediador da aliança - é apontado, porém, para além de sua administração, para uma época de descanso (vida plena em YHWH).

Moisés falou sobre este direito e ordenou que todos os membros da comunidade da aliança ansiassem pelo descanso vindouro na celebração do sábado, - antecipação da alegria do céu, - o sinal da aliança (Ex 31,14-17) e da consagração de Israel a uma missão sagrada (Ex 31,13), a fim de serem abençoados com todos os dons de YHWH na criação (Dt 26,18.19.; 28,3-14).

A vocação e o papel de Moisés foram fundamentais no que diz respeito ao cumprimento da promessa feita aos patriarcas. A sua missão não era um fim em si mesma, mas foi um largo passo para a conclusão da promessa que, primeiramente, foi feita por YHWH aos patriarcas, e agora, se estende ao povo liberto, que saiu do Egito com a finalidade de retornar à terra de seus pais: a terra da promessa. ${ }^{192}$

Em síntese, Moisés havia sido informado que não iria entrar na terra prometida, - ficou triste com a decisão de YHWH, mas acabou se conformando e aceitou - toma conhecimento que seu sucessor será Josué e se incumbiu de deixar a Lei escrita. O ato de colocar por escrito a Lei da parte de Moisés corresponde também ao ato de instituir Josué como seu sucessor. A Lei escrita serviria como um elemento facilitador nas mãos de Josué. "Se este se tornou, do ponto de vista físico, o guia do povo, o livro da Lei torna-se seu guia espiritual". 193

As lendas judaicas dão conta de que Moisés preparou treze cópias da Lei, uma para cada uma das doze tribos, e outra para ser deixada na arca, como salvaguarda, e como medida de segurança caso houvesse alguma corrupção em outras cópias da Lei, por parte de pessoas mau intencionadas (conforme se lê em Ebarim Rabba, séc. 9, fol. 244.2). Sempre havia ali uma edição original, com o propósito de comparar as cópias, mantendo assim, a fidelidade ao original. ${ }^{194}$

\footnotetext{
192 GARDNER, P., Quem é quem na Bíblia Sagrada, p. 466.

193 PAGANINI, S., Deuteronomio, p. 426.

${ }^{194}$ CHAMPLIN, R. N., O Antigo Testamento Interpretado: Versículo por versículo, p. 154.
} 


\subsection{2. \\ Entrega aos sacerdotes (v. 9bc)}

e a deu aos sacerdotes, filhos de Levi,

$9 b$

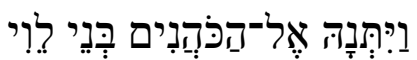

Moisés deixou o livro da Lei aos cuidados dos sacerdotes que eram encarregados de levar a arca da aliança. Ordenou-lhes que o colocassem junto à arca no Santo dos Santos, onde YHWH estava entronizado no propiciatório entre os querubins (S1 80,1). Isto quer mostrar que YHWH governa o mundo por sua palavra e o povo de YHWH deve respeitar essa palavra e lhe obedecer sempre. ${ }^{195}$

Foram os sacerdotes os escolhidos para a sublime missão e conforme as palavras do profeta Jeremias se pode afirmar que: "A Torá não faltará ao sacerdote, nem o conselho ao sábio, nem a palavra ao profeta" $(\mathrm{Jr} 18,18)$, pois é YHWH quem está no controle de todas as coisas.

Três termos são utilizados no AT para se referir às figuras envolvidas no culto, o termo mais recorrente é "sacerdote" (פָהן). Com referência ao sacerdócio a raiz significa aquele que foi "estabelecido" diante de YHWH para o servir. Se estiver em conexão com o santuário a raiz indica que o sacerdote é aquele que foi instalado em função do santuário. "Essa última compreensão parece encontrar algum respaldo na $\mathrm{BH}$, uma vez que o 'estabelecimento' de um santuário é muitas vezes indicado pela raiz כון, como em: Ex 15,17; Jz 16,26; Is 2,1". ${ }^{196}$

No AT a raiz כהן como verbo ocorre várias vezes no piel, significando a atuação de um sacerdote (Ex 31,10; Os 4,6). Na forma do substantivo, também existem várias ocorrências, em particular no livro de Levítico (Lv 1,12; 2,9; 4,20), descrevendo tanto os sacerdotes israelitas quanto os sacerdotes de outras divindades. 2Rs 10,19 cita os sacerdotes de Baal. A etimologia da palavra é incerta, pode ser: kântt do acádico, kahhen do siríaco, כִ כo hebraico, com significado de "ser firme" (Dt 10,8). Na maioria das ocorrências ذלה é um membro de um grupo sacerdotal distinto, definido tanto pela genealogia quanto pela função. ${ }^{197}$

\footnotetext{
195 WIERSBE, W. W., Comentário Bíblico Expositivo, p. 587.

${ }^{196}$ SIQUEIRA, F. S., Ml 2,1-9 e 2,17-3,5: Crise do Sacerdócio e Escatologia no séc. V a.C, p. 29.

197 JENSON, P., פלהן. NDITEAT [vol. 2], p. 599.
} 
Três funções sacerdotais são encontradas em textos antigos: O sacerdote é quem profere oráculos (Dt 33,7-11; Jz 18,5; 1Sm 14,41; 28,6); instrui na Lei (Dt 33,10); e oferece sacrifícios (Dt 33,10). ${ }^{198}$ Estas diferentes funções, ao que tudo indica, teriam um fundamento comum. ${ }^{199}$

Num certo sentido, todo Israel era sacerdote de YHWH: "Vós sereis para mim um reino de sacerdotes, uma nação santa" (Ex 19,6). Mas no Horeb/Sinai ele limitou o sacerdócio legítimo à família de Arão, da tribo de Levi (Ex 28,1; 40,12-

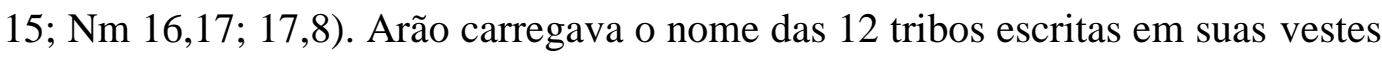
litúrgicas (Ex 28,12.21.29) de modo a apresentá-las diante de YHWH quando fosse ministrar a propiciação. ${ }^{200}$

Sendo assim, se pode dizer que os sacerdotes são os representantes de YHWH junto ao povo no que diz respeito a entrega de um oráculo e ao ensino da Lei. Mas também, são representantes do povo junto a YHWH no que concerne à realização do culto, através dos sacrifícios e oblações a YHWH pelo perdão dos pecados. ${ }^{201}$

Entre estas funções sacerdotais está o ministério de ensino, por isso Moisés deixa a Lei sob a responsabilidade dos sacerdotes, pois a Lei precisava ser lida e explicada. Naquela época, pouquíssimas pessoas, sabiam ler e escrever, daí a necessidade das leituras públicas. Se sabe que eram eles, os sacerdotes, descendentes da tribo de Levi, que transportavam a arca de um lugar para outro no deserto, que assumiram o ensino da Lei, pois eram qualificados para esta função. ${ }^{202}$

Portanto, se pode dizer que "a Torá pertence ao sacerdote, como o julgamento ao rei, o conselho ao sábio, a visão ou a palavra ao profeta”. ${ }^{203}$ Esta Lei que é confiada por YHWH aos sacerdotes (Dt 31,9.26), está relatada também em Dt 33,10, onde se enfatiza que a Lei de YHWH é ensinada a Israel.

\footnotetext{
${ }^{198}$ McKENZIE, J. L., Sacerdote. In: Dicionário Bíblico, p. 817.

${ }^{199}$ Segundo DE VAUX, R., (Instituições de Israel no Antigo Testamento, p. 395): "Quando o sacerdote entrega um oráculo, ele comunica uma resposta de YHWH; quando ele dá uma instrução (Torá), ele transmite e interpreta um ensinamento que vem de YHWH; quando ele leva sobre o altar o sangue e a carne das vítimas e quando aí queima o incenso, ele apresenta a YHWH as orações e os pedidos dos fiéis".

${ }^{200}$ PAYNE, J. B., פהזן In: HARRIS, R. L.; ARCHER, G. L.; WALTKE, B. K. DITAT, p. 705.

${ }^{201}$ Segundo FREITAS, T., (Análise exegética de Nm 18,1-7, p. 42): "No livro de Deuteronômio, claramente, todos os sacerdotes são levitas, mas às vezes pode haver certa confusão, levando o leitor a concluir que todos os levitas são sacerdotes (Dt 17,9.18; 18,1; 21,5). Contudo, há a distinção latente que demonstra que nem todos os levitas são sacerdotes (Dt 18,1.4.7). Distinção essa que fica explícita no livro do profeta Ezequiel (Ez 44,6-31)".

${ }^{202}$ CHAMPLIN, R. N., O Antigo Testamento Interpretado: Versículo por versículo. p. 154.

${ }^{203}$ DE VAUX. R., Instituições de Israel no Antigo Testamento, p. 392.
} 
No v. 9b, encontra-se o substantivo plural construto , "filhos de", acrescido do nome próprio "Levi" (לְ). ${ }^{204}$ Filho, primeiramente, significa o descendente por geração em primeiro grau, como: filho, sucessor, herdeiro; mas pode designar também outros parentescos, como: primo, tio, neto etc. Se for estendido a outras gerações significa: descendente, sucessor da linhagem. ${ }^{205}$

Era costume entre o povo hebreu chamar uma pessoa de filho daquilo que de um modo geral a caracterizava, de modo que ao nascido em Madiã se chamava "filho de Madiã" (Gn 25,4); aos que eram perversos se chamavam "filhos da perversidade" (Os 10,9); em Ez 3,11 se encontra a expressão "filhos do teu povo"; em Is 54,1 se tem "filhos da mulher solitária" e "filhos da casada". ${ }^{206}$

No período da peregrinação no deserto, YHWH escolheu Aarão como sumo sacerdote, seus filhos como sacerdotes e toda tribo de Levi ficou encarregada de ajudá-los nos serviços do tabernáculo e auxiliá-los no ofício do culto. ${ }^{207}$ Tribo esta, que seria mantida pelas demais tribos, em termos materiais, pois seu ofício era exclusivamente cuidar das coisas de YHWH. Em Dt 18,1-8, novamente, se vê o cuidado de YHWH com os sacerdotes e levitas. Uma vez que eles não receberam herança/território para sua tribo, o povo devia-lhes sustentar. ${ }^{208}$ Como relata o texto citado acima e especificamente o v. 2, "os rudimentos ou herança e direitos dos sacerdotes e levitas, sublinhando que "YHWH é a herança deles". ${ }^{209}$ Por isso não receberam terra em Canaã. Os sacerdotes são chamados de "filhos de

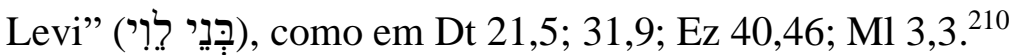

\footnotetext{
${ }^{204}$ Para SIQUEIRA, F. S. (Ml 2,1-9 e 2,17-3,5: Crise do Sacerdócio e Escatologia no séc. V a.C., p. 30): "O uso do termo לִ é muito amplo na BH: é o nome de um dos filhos de Jacó (Gn 29,34); designa, também, uma das doze tribos (Dt 18,1); aparece ligado a outros termos, gerando expressões como 'sacerdotes levitas' (Ez 43,19), 'filhos de Levi' (Gn 46,11; Ex 32,28; Ez 40,46; Ml 3,3)". ${ }^{205}$ ALONSO-SCHÖKEL, L., ᄁᄁ̣. In: Dicionário Bíblico Hebraico-Português, p. 106.

${ }^{206}$ Segundo LUND. E.; NELSON, P. C., (Hermenêutica, p. 26): se tem também alguns exemplos do NT: ao pacífico se chamava "filho da paz" (Lc 10,5-6); ao iluminado e entendido, "filho da luz" $(1 \mathrm{Ts} 5,5)$.

207 "O serviço levítico está mais relacionado ao trabalho físico dentro da tenda, não podendo se aproximar do que era a função exclusiva dos sacerdotes" (FREITAS, T., Análise exegética de Nm 18,1-7, p. 122).

${ }^{208}$ MACDONALD, W., Comentário Bíblico del Antiguo Testamento, p. 24.

${ }^{209}$ BENTHO, E. C.; PLÁCIDO, R. L., Introdução ao Estudo do Antigo Testamento, p. 155.

${ }^{210}$ De acordo com CARAGOUNIS, C. C., (קָ. NDITEAT, [vol. 1], p. 649-650): "O substantivo 'filho' (בָּ) aparece no AT cerca de 4.850 vezes. O termo tem vários sentidos: o significado mais comum é filho gerado por um pai (Gn 4,1.25; 21,2), embora a designação possa ser estendida a outros que não eram filhos biológicos. Ter muitos filhos era uma bênção especial de YHWH (Dt 28,4-11; 1Cr 28,5; S1 127,3-5)".
} 
O propósito divino de que Israel fosse uma nação santa, para comunicar ao mundo a vontade de YHWH reunir todas as nações em torno de si, requeria uma adoração sistemática, um rito organizado. Para isso, YHWH convoca Aarão para servir como sumo sacerdote. Os sacerdotes ofereciam os sacrifícios e lideravam o povo na expiação pelo pecado (Ex 28,1-43; Lv 16,1-34). Na qualidade de guardiões da Lei, eles também eram os mestres da Lei.

Todavia, segundo o relato bíblico, até o momento do recebimento da Lei e da construção do tabernáculo, os israelitas nada mais eram do que um agrupamento de clãs. A partir de então, passaram a se organizar como tribos ao redor do tabernáculo, sem uma centralização política, mas como uma espécie de confederação que tinha como vínculo a fé em YHWH. Uma das determinações de YHWH foi a distribuição das tribos ao redor do tabernáculo durante o tempo que vivessem no deserto até que se estabelecessem na terra de Canaã (Nm 2). ${ }^{211}$

Desta forma, dos sacerdotes requeria-se que vivessem santamente: "Depois disse o Senhor a Moisés: fala aos sacerdotes, filhos de Arão, e dize-lhes: 'O sacerdote não se contaminará" ( $\operatorname{Lv} 21,1 ; 22,10)$. Eles tinham vestimentas especiais (Ex 28,40-43; 39,27-29), como também o sumo sacerdote (Ex 28,4-39). Os sacerdotes e o sumo sacerdote tiveram uma bela cerimônia de consagração (Ex $29,1-37 ; 40,12-15 ; \operatorname{Lv} 8,1-36){ }^{212}$

Do sumo sacerdote era exigida a máxima santidade; depois, com menor observância de detalhes, dos sacerdotes, porque estavam em contato com o altar. Os levitas ocupavam uma posição intermediária; seu ofício era o de cuidar do tabernáculo (vigiá-lo a fim de evitar profanação) e estar ao serviço do povo. ${ }^{213}$

Ainda no v. 9b, se pode atentar para a presença do verbo נָָּּ, muitíssimo no AT. Importante ressaltar que enquanto כָָּ tem somente um sentido, "escreveu" (v. 9a), o verbo נָָת expressa muitos significados (v. 9b). ${ }^{214}$ Mas o contexto da

\footnotetext{
${ }^{211}$ REINKE, A. D., Atlas Bíblico Ilustrado, p. 34.

${ }^{212}$ PAGANELLI, M., Introdução ao Estudo da Tipologia Bíblica, p. 85-86.

${ }^{213}$ SIQUEIRA, F. S., Ml 2,1-9 e 2,17-3,5: Crise do Sacerdócio e Escatologia no séc. V a.C., p. 74. 214 “O verbo נָָ é um dos verbos mais usados no AT, cerca de 2000 vezes (a maioria delas no grau $q a l)$, não é de surpreender que se encontre nas traduções uma grande variedade de sentidos. Além de seu sentido básico e mais frequente de 'dar', podem-se citar 'presentear', 'permitir', 'oferecer', 'empregar', 'transmitir', 'pôr', 'estabelecer', 'tomar'. Os três amplos campos semânticos do verbo

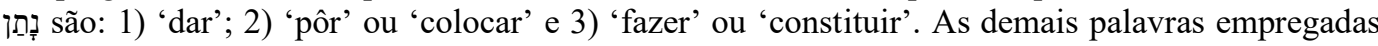
nas traduções são extensões ou variações destas" (FISHER, M. C., Ĩָּ In: HARRIS, R. L.; ARCHER, G. L.; WALTKE, B. K. DITAT, p. 1017-1018).
} 
perícope absorve plenamente o seu uso mais simples, "dar", que se refere a entrega da Lei àqueles que serão os responsáveis por cuidar e transmitir os ensinamentos de YHWH: os sacerdotes, filhos de Levi.

Aos sacerdotes é confiada a guarda do livro e a leitura da Lei a todo o Israel. ${ }^{215}$ Os levitas tinham a responsabilidade e o dever de cuidar da Lei escrita (do livro). Deveriam guardá-lo com cuidadosa vigilância, como se se tratasse de um tesouro precioso. Deveria ficar junto com a arca da aliança, pois ali estavam as tábuas/pedras da Lei. ${ }^{216}$ Portanto, na arca da aliança estava a primeira legislação o decálogo - e, também, a reformulação da Lei - o livro.

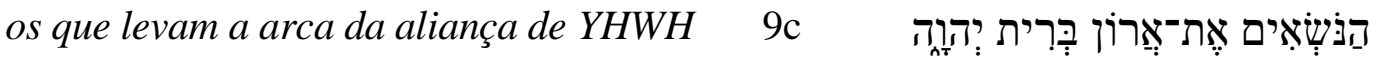

Em Dt 31,9c aparece um particípio masculino plural: “os que levam”

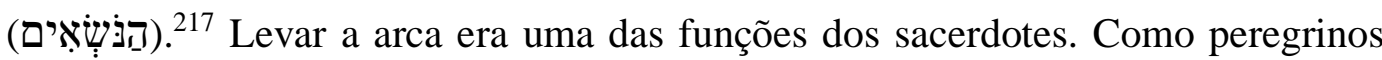
no deserto, precisavam transportar a arca todas as vezes que YHWH se manifestava, indicando que era hora de levantar o acampamento e sair em peregrinação. Esses sacerdotes, filhos de Levi, eram chamados também de sacerdotes itinerantes. ${ }^{218}$

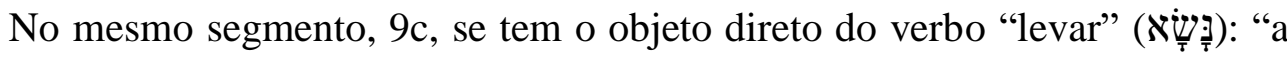

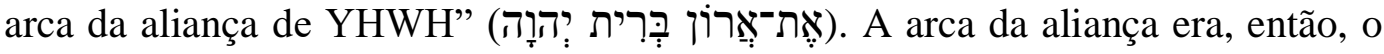
principal símbolo do acordo entre YHWH e Israel, pois ali estava guardada a Lei, que representava o compromisso entre YHWH e Israel.

O substantivo masculino, "arca" (אֶרוֹ) é muito presente no AT (193 vezes). Aceita-se que seja derivado da raiz ארן: ${ }^{219} \mathrm{O}$ substantivo designa uma caixa usada

\footnotetext{
${ }^{215}$ MANLEY, G. T., Novo Comentário da Bíblia, p. 77.

${ }^{216}$ MACDONALD, W., Comentário Bíblico del Antiguo Testamento, p. 35.

217 "O grau qal do verbo Jְָ̦ 'ele levou', é empregado quase 600 vezes com basicamente três sentidos distintos: 1) erguer; 2) suportar, carregar; 3) tomar, levar embora. A raiz aparece em ugarítico como $n s ̌$ ': 'erguer', 'levantar', e em acadiano como našū. Existem outras 60 ocorrências nos graus niphal, piel e hitphael. Há apenas duas ocorrências no hiphil (Lv 22,16 e 2Sm 17,13). O total de usos do verbo em todos os graus é 655" (KAISER, W. C., נָָׁׁ. In: HARRIS, R. L.; ARCHER, G. L.; WALTKE, B. K. DITAT, p. 1003).

218 "O Deuteronômio representa uma vasta coleção das pregações desses levitas itinerantes, que se apresentavam como pregadores com a missão de ensinar a lei (Dt 31,9-13), explicando-a, aprofundando-a e aplicando-a às situações concretas do povo. Como vemos, o Deuteronômio é o resultado de um "esforço pastoral' dos levitas itinerantes, que procuravam tornar concreta na vida prática a aliança que era renovada nos santuários, por ocasião das festas." (STORNIOLO, I., Como Ler o Livro do Deuteronômio, p. 25).

${ }^{219}$ LEWIS, J. P., אָרוֹ. In: HARRIS, R. L.; ARCHER, G. L.; WALTKE, B.K. DITAT, p. 123.
} 
para diversos fins. Os restos mortais de José foram colocados em um caixão no Egito para o seu futuro sepultamento na Palestina (Gn 50,26). O substantivo אֶרוֹ é mais frequentemente usado para se referir à arca da aliança, que foi feita para guardar as placas de pedras da Lei. A embarcação feita por Noé é designada pelo hebraico quָרָה que pode ser traduzido também por arca.

Como se vê no hebraico se tem um termo próprio para se referir à arca sagrada, aquela que foi feita mediante as determinações de YHWH, para guardar os primeiros registros da Lei, que foram escritos pelo próprio YHWH, e posteriormente, também o livro escrito por Moisés. No livro de Êxodo está escrito que Bezabel fez a arca da aliança de madeira de acácia $\left(\right.$ Ex 37,1). ${ }^{221}$

Em Dt 31,24-27 se diz que o livro da Lei está em conexão com a arca em que, de acordo com Dt 10,1-8, as tábuas/pedras do decálogo estão guardadas. Essas instruções estão relacionadas com Dt 31,9-13.222

Os dois textos se relacionam Dt 31,24-27 e Dt 31,9-13. O primeiro fala: "Agora tendo acabado de ler integralmente as palavras do livro (v. 24), dá ordem para que o livro seja colocado ao lado da arca da aliança de YHWH (v. 26).” O segundo diz que "Moisés escreveu a Lei e deu aos sacerdotes, filhos de Levi e aos anciãos de Israel” (v. 9). Neste, não aparece a indicação de colocar o livro junto da $\operatorname{arca}^{223}$

Paralelamente à Lei está o cântico de Moisés, que foi escrito por ordem de YHWH (Dt 31,19), para advertir sobre o grande risco que corriam em função de não observarem a Lei. O cântico, também, servirá de testemunho a favor de YHWH, caso, Israel seja seduzido e se desvie pela idolatria. ${ }^{224}$

Receber a palavra e lhe obedecer é participar intimamente da vida de YHWH. "Porque não é uma palavra inútil para vós, porque ela é a vossa vida, e é

\footnotetext{
220 "O substantivo , תבָד que também foi traduzido por arca em português, não deve ser confundido

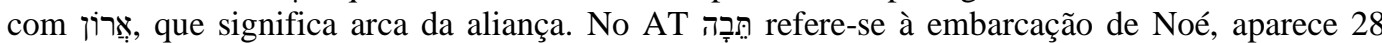
vezes com este sentido, mas em outras duas vezes se refere à pequena embarcação que a mãe de Moisés confeccionou para que ele navegasse pelo Nilo, na esperança de salvá-lo da ordem do Faraó para que todo menino recém-nascido fosse afogado nas águas desse rio (Ex 2,3.5). Infelizmente, esse termo sempre foi traduzido da mesma forma que אִ: Em decorrência disso, a

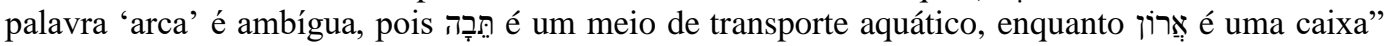
(HAGUE, S. T., תרֶָ. NDITEAT [vol. 4], p. 268).

${ }^{221}$ LEWIS, J. P.,

${ }^{222}$ BARTON, J.; MUDDIMAN, J., The Oxford Commentary, p. 154.

${ }^{223}$ BENTHO, E. C.; PLÁCIDO, R. L., Introdução ao Estudo do Antigo Testamento, p. 162.

${ }^{224}$ BLENKINSOPP, J., Deuteronômio. In: BROWN, R. E.; FITZMYER, J. A.; MURPHY, R. E. Novo Comentário Bíblico São Jerônimo: Antigo Testamento, p. 248.
} 
por esta palavra que prolongareis vossos dias sobre o solo do qual ides tomar posse, ao atravessar o Jordão" (Dt 32,47). ${ }^{225}$

A arca da aliança é o objeto que mais frequentemente é aludido na Sagrada Escritura, e está repleta de ensinamentos nos vários fatos ocorridos em sua trajetória acompanhando o povo de Israel. À medida que se vai observando essa trajetória, através do deserto e do Jordão, até sua chegada em Gilgal, ao redor das muralhas de Jericó até Siló; depois até à terra dos filisteus, e de volta através de Bet-Sames, Quireat-Jearim, e a casa de Obed-Edom, até finalmente repousar no seu lugar na tenda em Jerusalém e no Templo de Salomão. Se pode, então, notar, um paralelismo entre a história de Israel e a história da arca. ${ }^{226}$

No percurso da história de Israel, Salomão constrói um Templo em honra ao nome do Senhor e introduz nele a arca, pois nela estavam os símbolos da aliança entre YHWH e Israel. Isto para fazer lembrar que YHWH sempre guarda as suas alianças (2Cr 6,10-11.14). Israel podia falhar, mas YHWH nunca falharia.

A arca era um objeto sagrado, e como tal, não podia ser profanado, YHWH havia proibido que entrassem no Santo dos Santos ou que contemplassem a arca $(\mathrm{Nm} 4,20)$. Ela nunca ficou exposta aos olhares do povo, pois mesmo quando era transportada de um lugar para outro, se tinha o cuidado de cobri-la. Quando o tabernáculo estava para ser removido, - pois iam levantar acampamento de um local para outro - o véu era descido sobre a arca, a fim de que ninguém a contemplasse.

Sendo símbolo da presença de YHWH, ela tinha um poder formidável. No episódio em que os homens de Bet-Sames foram feridos por olharem para dentro dela, pois foram demasiadamente curiosos, demonstra a soberania do Deus de Israel $(1 \mathrm{Sm} 6,19)$. Oza morre por tê-la tocado (2Sm 6,6-7). Essa era a pena imposta ao que se aproximasse dela de forma indevida. ${ }^{227} \mathrm{Nem}$ os levitas podiam tocar na arca, para isso eles usavam duas varas, que eram colocadas uma de cada lado da arca, em posição horizontal (Ex 25,14-15; 1Rs 8,8) e só se aproximavam dela quando já tinha sido totalmente coberta pelos sacerdotes $(\mathrm{Nm} 4,5.15) .{ }^{228}$

\footnotetext{
${ }^{225}$ WIERSBE, W. W., Comentário Bíblico Expositivo, p. 591-592.

${ }^{226}$ HABERSHON, A. R., Manual de Tipologia Bíblica, p. 61.

${ }^{227}$ Ex 28,43; 30,20; Lv 10,6.9; 16,2.13; 22,9; Nm 4,15.19.20; 17,28; 18,3.22.

${ }^{228}$ DE VAUX, R., Instituições de Israel no Antigo Testamento, p. 337.
} 
Fato semelhante ocorreu com Moisés, mas este age de maneira diferente, pois seguiu as instruções de YHWH. Na passagem da sarça ardente, Moisés se aproxima para ver o "por quê" a sarça não se consumia, é nesse momento que YHWH diz: "Não se aproxime. Tire as sandálias dos pés, pois o lugar em que você está é terra santa" (Ex 3,3-5). Nada aconteceu com Moisés, pois fez como YHWH ordenara. ${ }^{229}$

Ainda em Dt 31,9c explorando o tema da aliança estabelecida unicamente pela vontade de YHWH, se pode dizer, que a aliança com Israel tem a ver com a aliança feita com Abraão (Gn 15,9-11) e por outro lado uma obrigação que YHWH impõe ao povo que ficará sob a sua proteção. ${ }^{230} \mathrm{Em}$ ambos os casos é o próprio YHWH quem faz e estabelece a relação (Gn 17,2.10.13-14; Ex $34,10.27){ }^{231}$

Estas são as fórmulas da aliança: "Que ele se torna Deus para ti” (Dt 26,17) e "que tu te tornas seu povo-propriedade" (Dt 26,18), no contexto geral isso aparece como uma declaração expressa de Israel que assumirá a prometida posição especial como povo-propriedade de YHWH e como "povo santo" (Dt 26,19) e corresponderá a ela mediante a observância da Torá. ${ }^{232}$

O livro de Deuteronômio faz alusão ao tema da aliança cerca de 27 vezes, tamanha é sua importância na história de Israel. Enquanto o substantivo pode significar um contrato baseado em condições, pode também, empregar-se no sentido de um parentesco adquirido entre duas partes. Este pode ser de fraternidade, como entre Davi e Jônatas (1Sm 18,33), ou de soberania, como entre Davi e Israel, ou de pura graça, como na aliança de YHWH com Noé $($ Gn 9,9). Também na aliança do Horeb/Sinai, YHWH por pura graça, tomou Israel para seu povo, que por sua vez, tomou YHWH como seu Deus (Ex 19,5.8). Então receberam a Lei, os Dez Mandamentos (Ex 34,28; Dt 9,9), juntamente com os estatutos e juízos, o qual deveriam obedecer em virtude da aliança já feita. ${ }^{233}$

Como se vê a aliança simboliza o compromisso de YHWH - no contexto em que ele revela a si próprio - mediante seu servo Moisés, em prol da relação

\footnotetext{
229 "Decerto esse mistério muito maior deve ser tratado por cada um com reverência ainda mais profunda" (HABERSHON, A. R., Manual de Tipologia Bíblica, p. 61-68).

${ }^{230}$ Ex 19,5; 24,7; Js 24,25; 2Rs 23,3.

${ }^{231}$ SCHMIDT, W. H., A fé do Antigo Testamento, p. 185-186.

${ }^{232}$ RENDTORFF, R., A "Fórmula da Aliança", p. 34.

${ }^{233}$ MANLEY, G. T., Novo Comentário da Bíblia, p. 22.
} 
que assume com o povo eleito. A aliança vai, assim, marcar toda a história e existência de Israel, já que implica, diretamente, na obediência à Lei de YHWH. ${ }^{234}$

Sendo assim, a autorrevelação divina acontece mediante a manifestação dos seus atributos e do seu caráter. Ele é um Deus gracioso, que faz promessas incondicionais aos pais e a Israel ${ }^{235}$ e que continua oferecendo bênçãos ao seu povo no presente e no futuro. ${ }^{236}$

Um termo determinante no caráter de YHWH é o substantivo "graça" (חֶֶֶָ), pois apesar de YHWH estar na posição de Senhor e Israel na posição de servo, YHWH diante da aliança age graciosamente, e assim, se obriga aos seus escolhidos (Dt 5,10; 7,9.12; 33,8). Isto, simplesmente, porque quis que Israel fosse seu povo, e sobretudo, porque amou esse povo mesmo antes de ser amado por ele. ${ }^{237}$

O primeiro mandamento do decálogo determina a relação entre YHWH e o povo, mas não faz nenhuma afirmação direta sobre o próprio YHWH. É em Dt 6,4 , que se vai encontrar a possibilidade de entender o relacionamento nesse sentido: "YHWH é o único Deus". Também os textos de Zc 14,9 e Ml 2,10 apontam para essa visão. No AT, o livro de Deuteronômio, em particular, enuncia o ser de YHWH (Dt 4,35.39; 6,4; 7,9). ${ }^{238}$

Aos poucos Israel vai conhecendo o seu Deus, pois YHWH atua na história, como único e verdadeiro Deus, e vai conduzi-lo, dando todas as condições para permanecerem na sua companhia e amizade. Portanto, YHWH cuida do destino de Israel e, também, de todos os povos do mundo inteiro (Os 12,10; 13,4; Is 45,5). ${ }^{239}$

A obrigação com a aliança impõe para os israelitas a obediência total a YHWH. A presença do tema da obediência nos textos sobre o amor inexplicável de YHWH é relevante para com Israel. Tudo parte de YHWH, é ele quem escuta o clamor do povo (Ex 3,9) e introduz Moisés como libertador (Ex 3,10). É o seu primeiro ato de amor dentro do contexto da escravidão do Egito. Ato este que é realizado por um Deus soberano, que apesar de ser soberano, age literalmente

\footnotetext{
${ }^{234}$ GALVAGNO, G.; GIUNTOLI, F., Pentateuco, p. 298.

${ }^{235}$ Dt $1,8.11 ; 3,18.20-21 ; 4,31 ; 6,10 ; 7,8 ; 9,5.27-28 ; 10,15 ; 11,9.21 ; 28,9 ; 29,13$.

${ }^{236}$ Dt 1,10.20.21.25.35; 2,7; 7,13-16; 8,10.18; 10,22; 11,14-17; 12,1.21; 14,24.29.

${ }^{237}$ ZUCK, R. B., Teologia do Antigo Testamento, p. 82.

${ }^{238}$ SCHMIDT, W. H., Introdução ao Antigo Testamento, p. 132.

${ }^{239}$ FERNANDES, L. A., O êxodo da casa do sogro é prenúncio do êxodo do país opressor (Ex 4,19-23), p. 133-134.
} 
através da graça. Um ato gratuito, que demonstra o quanto YHWH é bom. É através dessa graciosidade e generosidade que YHWH: liberta, cuida e ainda tem uma aliança a propor e uma herança a ofertar. A única coisa que YHWH espera da parte de Israel, é que ele o adore como único Deus. ${ }^{240}$

Importante perceber que o livro de Deuteronômio enfatiza que a lealdade a YHWH é a essência da verdadeira espiritualidade. Este princípio não permite acordo com nada que seja contrário a YHWH e exige separação de todas as relações e práticas ilegítimas. ${ }^{241}$

YHWH sempre intervêm a favor do seu povo, isso mostra que ele é um benfeitor, um protetor. Todo esse cuidado evidencia-se através da sua graça, que é pura gratuidade. Ele cumpriu sua promessa, multiplicando-lhes os habitantes (Dt $1,10 ; 10,22)$ e concedendo-lhes prosperidade física e material (Dt 32,15-18). Estas foram as bênçãos concedidas por YHWH.

Dentro dos acordos de vassalagem, se têm compromissos a serem cumpridos, mas também benefícios grandiosos, ainda mais se tratando de uma aliança com YHWH. ${ }^{242}$

Os tratados do AOP revestem-se de suma importância, visto que eles esclarecem as alianças e tratados encontrados nas Escrituras Veterotestamentárias. Encontra-se entre os hititas e, também, entre outros povos a forma de tratados de suserania, onde o tratado era firmado entre um soberano (suserano) e um vassalo (súdito). $\mathrm{O}$ mesmo, era elaborado pelo poder superior e imposto ao inferior. ${ }^{243}$

A Lei que YHWH entregou a Moisés não foi o único código legal a sobreviver no AOP. Vários outros são dignos de nota: as 60 leis da cidade-estado de Eshnunna, na região central da Mesopotâmia, datadas de cerca de 1800 a.C.; o famoso código de Hammurabi (com cerca de 282 leis), rei da Babilônia (17921750 a.C.), gravadas numa estela de basalto polido com $2,7 \mathrm{~m}$ de altura, levada como despojo a Susa, no sudoeste do Irã, e hoje faz parte do acervo do museu do Louvre, em Paris; as 200 leis hititas, datadas de cerca de 1600 a.C.; as 128 leis da Média Assíria, datadas do reinado de Tiglate-Pileser I (1115-1077 a.C.). ${ }^{244}$

\footnotetext{
${ }^{240}$ BRUEGGEMANN, W., Teologia do Antigo Testamento, p. 552.

${ }^{241}$ LIVINGSTON, G. H., Comentário Bíblico Beacon, p. 413.

${ }^{242}$ ZUCK, R. B., Teologia do Antigo Testamento, p. 78.

${ }^{243}$ DOCKERY, D. S., Manual bíblico vida nova, p. 181.

${ }^{244}$ LAWRENCE, P., Atlas Histórico e Geográfico da Bíblia, p. 38-39.
} 
As leis de Eshnunna e Hammurabi, ${ }^{245}$ e as leis de Moisés, podem sugerir uma interrelação. As semelhanças encontradas entre os códigos legais refletem um conjunto comum de valores presentes na cultura do AOP nesse período. Há uma semelhança no que diz respeito à sequência das leis entre os códigos mencionados acima e as leis de Moisés: com cerca de 138 prescrições nos livros de Êxodo e Levítico, e 101 prescrições no livro de Deuteronômio. ${ }^{246}$

Uma aliança requer um contrato escrito, ${ }^{247}$ e Moisés o redige como testemunho de um compromisso comunitário e oficial. Este "contrato" foi redigido da mesma forma como funcionavam os contratos de vassalagem daquela época. E é nessa estrutura de documento da aliança que estão as bases para a composição de toda Torá. ${ }^{248}$

O código de Hammurabi não se apresenta como o único do AOP, que tenha demonstrado exercer uma particular influência na legislação bíblica. ${ }^{249}$ Acreditase que também houve influência hitita no modo como realizavam os pactos.

A seguir, apresentam-se dois exemplos comparados: No primeiro, encontrase a estrutura do Pacto de vassalagem hitita com o Pacto Sinaítico. No segundo, a formulação do tratado Hitita e os prováveis paralelos no livro de Deuteronômio.

Observando as tabelas, não é difícil identificar a mesma estrutura fundamental do Pacto Sinaítico do livro de Êxodo e do livro de Deuteronômio com os Tratados Hititas, provavelmente, foram influenciados pelos códigos de vassalagem do AOP. ${ }^{250}$

\footnotetext{
${ }^{245}$ Segundo MENEZES, V. M., (Código Hammurabi e a Lei de Moisés, p. 36): O Código de Hammurabi foi encontrado em 1901 (XVIII a.C.). Existem outros códigos ainda mais antigos como: um código sumérico que é aproximadamente dois séculos mais antigo que o de Hammurabi, um outro babilônico mais velho ainda e, se tem também, o Código Hitita (XIV a.C.).

${ }^{246}$ LAWRENCE, P., Atlas Histórico e Geográfico da Bíblia, p. 39.

${ }^{247}$ As pesquisas modernas demonstraram que no âmbito da Ásia Menor até o Egito, do século XIV até o século VIII a.C., existia um gênero especial de pacto com uma formulação semelhante ao documento da aliança, os chamados: "tratados de vassalagem". Trata-se de acordos entre um Senhor e os povos por ele subjugados (MCCARTHY, M. S., Per uma Teologia del Pacto nell'AT, p. 134-137).

${ }^{248}$ MANNUCCI, V., Bíblia, palavra de Deus, p. 77.

${ }^{249}$ GALVAGNO, G.; GIUNTOLI, F., Pentateuco, p. 227.

${ }^{250}$ Houve tentativas de fazer um código de leis unificado na Mesopotâmia, em cidades como Lagash, Ur e Eshnunna. A mais famosa tentativa foi do rei Hammurabi (c. 1810-1750 a.C.). Hammurabi procurou reformar e unificar as leis em seu reino. Essas leis estão esculpidas em uma estela de rocha negra (REINKE, A. D., Os outros da Bíblia, p. 48).
} 
Estrutura do Pacto de vassalagem Hitita e do Pacto Sinaítico. ${ }^{251}$

\begin{tabular}{|l|l|}
\hline \multicolumn{1}{|c|}{ Pacto de Vassalagem Hitita } & \multicolumn{1}{|c|}{ Pacto Sinaítico do livro de Êxodo } \\
\hline Preâmbulo (nomes e títulos do Rei). & Preâmbulo (Ex 20,2). \\
\hline $\begin{array}{l}\text { Prólogo histórico (os benefícios do Rei com } \\
\text { relação ao vassalo). }\end{array}$ & Prólogo histórico (Ex 20,2). \\
\hline \begin{tabular}{l} 
Obrigações impostas ao vassalo. \\
\multicolumn{1}{|c|}{ referentes à conservação do }
\end{tabular} & $\begin{array}{l}\text { O documento escrito do pacto (Ex 24,3-7) e a } \\
\text { sua releitura (Dt 31,9-13.24-28). }\end{array}$ \\
\hline $\begin{array}{l}\text { Cláusulases / Decálogo (Ex 20,3-17). } \\
\text { documento escrito do pacto e a sua periódica } \\
\text { leitura pública. }\end{array}$ & $\begin{array}{l}\text { O sacrifício que sela a aliança (Ex 24,8). O } \\
\text { esquema é ainda mais evidente na renovação da } \\
\text { Aliança em Siquém (Js 24). }\end{array}$ \\
\hline $\begin{array}{l}\text { Invocação dos deuses como testemunhas. } \\
\text { (Sem Paralelo) }\end{array}$ \\
\hline $\begin{array}{l}\text { Bênçãos e maldições ligadas à observância ou à } \\
\text { infração do pacto. }\end{array}$
\end{tabular}

Estrutura do Tratado Hitita comparado a Lei de Deuteronômio. ${ }^{252}$

\begin{tabular}{|c|c|}
\hline Forma do Tratado Hitita & Paralelo no livro de Deuteronômio \\
\hline $\begin{array}{l}\text { Preâmbulo: } \\
\text { Identifica as partes do tratado. }\end{array}$ & Dt $1,1-5$ \\
\hline $\begin{array}{l}\text { Prólogo Histórico: } \\
\text { Recapitula os acontecimentos que levaram ao } \\
\text { tratado. }\end{array}$ & Dt $1,6-3,29$ \\
\hline $\begin{array}{l}\text { Estipulações Gerais: } \\
\text { Estabelece o conteúdo do relacionamento futuro } \\
\text { e resume o propósito das estipulações } \\
\text { específicas. }\end{array}$ & $\begin{array}{l}\text { Dt 4-11 } \\
\text { Esta é uma longa exortação de Moisés para } \\
\text { Israel obedecer a YHWH. }\end{array}$ \\
\hline Estipulações Específicas. & $\begin{array}{l}\text { Dt } 12-26^{*} \\
\text { O sermão continua com a exposição detalhada } \\
\text { do que a lei exige de Israel. }\end{array}$ \\
\hline Bênçãos e Maldições. & Dt $27-28$ \\
\hline $\begin{array}{l}\text { Cláusula sobre o Documento: } \\
\text { Exige que se armazene e leia periodicamente o } \\
\text { tratado. }\end{array}$ & Dt $27,1-5$ \\
\hline $\begin{array}{l}\text { Testemunhas Divinas da Aliança: } \\
\text { Várias divindades são invocadas para } \\
\text { testemunhar o tratado. }\end{array}$ & $\begin{array}{l}\text { Dt 29-33 } \\
\text { Moisés convoca o céu e a terra como } \\
\text { testemunhas da aliança em ter YHWH e Israel } \\
\text { (Dt 30,19; } 31,28 ; 321-43 \text { ). }\end{array}$ \\
\hline (Sem Paralelo) & $\begin{array}{l}\text { Dt } 34 \\
\text { Morte de Moisés. }\end{array}$ \\
\hline
\end{tabular}

A partir desse processo de vassalagem, é interessante notar, que Israel no Egito tinha o Faraó como seu suserano, mas diante da aliança com YHWH se dá um relacionamento diferente, pois aquele que os chamara pela graça da eleição como povo escolhido, endossou a chamada historicamente, pelo ato de libertá-los

${ }^{251}$ MCCARTHY, M. S., Per uma Teologia del Pacto nell'AT, p. 149-151.

${ }^{252}$ HAYS, J. D.; DUVALL, J. S., Manual Bíblico Ilustrado Vida, p. 109. 
de um soberano opressivo para que o povo entendesse a fidelidade e o poder incomparável de YHWH, que realizou muitos prodígios nessa trajetória. ${ }^{253}$

Portanto, se a nação de Israel, obedecesse a YHWH e o servisse com alegria, seu rosto resplandeceria sobre eles e estariam sempre protegidos pela bênção de YHWH (Nm 6,22-27), esta era a finalidade da aliança, viver sob a proteção de YHWH, desta forma, nada lhes faltaria. ${ }^{254}$

Levando em conta a estrutura e teor da aliança que foi renovada no livro de Deuteronômio, a função dominante de YHWH é a de Senhor soberano do universo, que escolheu Israel, um povo insignificante, a fim de executar o seu plano para o mundo, ou seja, Israel será uma grande nação e servirá de sinal para todos os povos.

Na sua pedagogia YHWH estabelece o livro da Lei - a Torá - que foi dada a Israel, para servir de diretriz, de base para uma vida santa. Esse era o meio eficaz para Israel alcançar o objetivo de YHWH: servir como um paradigma de como se deve viver, pois faz parte da função dessa Lei estabelecer Israel como nação separada das outras, com o objetivo principal de atraí-las para o Deus único. "O povo vivencia um tipo diferente de sociedade porque conhece e adora um tipo diferente de Deus".255

Sendo assim, se pode dizer que Israel foi escolhido para demonstrar historicamente como deveria ser o domínio de YHWH na terra, e a terra de Canaã foi escolhida como sinal, no qual o mundo teria um vislumbre dessa soberania acontecendo. Sua conquista e ocupação serviriam como protótipo da conquista e ocupação universal, que é tema importante da mensagem escatológica dos profetas. ${ }^{256}$ "Israel foi chamado para agir no palco do mundo como uma nação que representava YHWH". ${ }^{257}$

\footnotetext{
${ }^{253}$ ZUCK, R. B., Teologia do Antigo Testamento, p. 78.

${ }^{254}$ WIERSBE, W. W., Comentário Bíblico Expositivo, p. 588.

${ }^{255}$ VOGT, P. T., Interpretação do Pentateuco, p. 112.

${ }^{256}$ ZUCK, R. B., Teologia do Antigo Testamento, p. 82-84.

${ }^{257}$ VOGT, P. T., Interpretação do Pentateuco, p. 138.
} 


\subsection{3. \\ E aos anciãos (v. 9d)}

$e$ [deu] a todos os anciãos de Israel.

Os levitas já eram os encarregados de levar a arca da aliança (Dt 10,8-9) e agora, também, estão encarregados de guardar o livro da Lei, eles e os anciãos de Israel, que já exerciam certas tarefas de liderança (Dt 21,2; 27,10). Como se vê, Moisés vai delegando responsabilidades a outros membros da comunidade. "É como se a liderança de Moisés fosse sendo multifacetada, e distribuída através de diferentes líderes, embora todos estariam encabeçados e liderados por Josué". ${ }^{258}$

Há uma distinção entre os sacerdotes e os anciãos. Os anciãos eram os mestres da Lei e os líderes das tribos de Israel, responsáveis também por ensinar a Torá; mas o ofício do culto era de responsabilidade dos sacerdotes que pertenciam à tribo de Levi. ${ }^{259}$

Em alguns textos, os anciãos aparecem como as testemunhas privilegiadas de eventos chave da história de Israel. Em outros, eles são os primeiros destinatários de mensagens divinas, o que demonstra a importância deles diante de YHWH como representantes do povo. A primeira menção dos "anciãos de Israel" se encontra em Ex 3,16.18, na cena da sarça ardente. Quando YHWH explica a Moisés os detalhes sobre seu plano de salvação para Israel (Ex 3,16-22), inicia seu discurso do seguinte modo: "Vai, reúne os anciãos de Israel e dize-lhes". ${ }^{260}$

Os estudiosos não deixam dúvidas de que a competência para a interpretação e ensino da Torá passa pelos sacerdotes, filhos de Levi, que, junto aos anciãos, devem instruir o povo na terra prometida. Moisés entrega aos sacerdotes e anciãos o registro escrito da Torá sinaítica, agora, interpretada na Torá Moabita. Esse registro será a base para ação pedagógica daqueles que foram convocados por Moisés para instruir Israel. Tanto o registro escrito da Lei (Dt 31,9-13) deve ser guardado junto a arca (Dt 31,26), quanto o registro do cântico (Dt 31,19; 32,1-43), para assim estarem em segurança, e, em contrapartida, eles devem estar acessíveis a todos, pois todos devem observar e conhecer a Lei. ${ }^{261}$

\footnotetext{
${ }^{258}$ AZCÁRATE, J. L. L., Deuteronomio, p. 278.

${ }^{259}$ MANLEY, G. T., Novo Comentário da Bíblia, p. 77.

${ }^{260}$ SKA, J. L., Antigo Testamento: Temas e Leituras, p. 174.

261 “Assim como o decálogo, a Torá deve ser a base da vida na terra prometida somente na forma da interpretação mosaica” (OTTO, E., A Lei de Moisés, p. 97-98).
} 
Os anciãos eram pessoas respeitadas por todos de sua tribo, pelos longos anos de vida - bênção de YHWH - eram como sábios, devido à grande experiência de vida, sendo assim, faziam parte dos notáveis mais importantes de Israel. Permanecem ao lado de Moisés, também junto ao povo, como responsáveis pelo cumprimento da Lei, pela fidelidade ou infidelidade do povo (Dt 31,28).

Tais anciãos, ao mesmo tempo que são os responsáveis pelo povo diante de YHWH, no que diz respeito a observância da Lei, também atuavam no meio da sociedade como legisladores. ${ }^{262}$

O substantivo Tזָ não foi traduzido por um adjetivo, "velho", mas por um substantivo que denota o valor do ancião. No texto se refere aos líderes tribais que tinham o dever de administrar as coisas de YHWH e fazer cumprir as suas ordens. $^{263}$

Os primeiros a saberem da proposta da aliança com YHWH são os anciãos (Ex 19,7). Dada a importância da sua figura frente ao povo, eles se tornam os guardiões da aliança, tamanha era a credibilidade que tinham diante de todos. Em Dt 31 verifica-se a aliança na terra de Moab, como se pode atestar em 31,9, Moisés escreve a Lei e deixa aos cuidados dos sacerdotes, filhos de Levi, e dos anciãos.

Todavia, em outro episódio (Dt 31,24-25), Moisés fala apenas aos sacerdotes e entrega-lhes a Lei. Somente os sacerdotes terão a prioridade de cuidar da Lei, mas logo em seguida sugere-lhes que reúnam os anciãos e os oficiais para pronunciar mais um discurso. Os levitas, portanto, agiam como porta-vozes de YHWH ao lado de Moisés e os anciãos eram os representantes do povo. ${ }^{264}$

\footnotetext{
${ }^{262}$ SKA, J. L., Antigo Testamento: Temas e Leituras, p. 174.

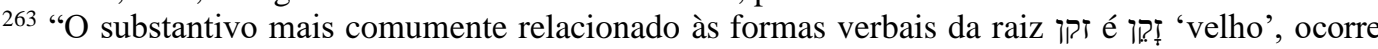
187 vezes no AT. A palavra 18,$12 ; 19,31 ; 25,8 ; 35,29 ; 44,20$ ), normalmente em contraste com a mocidade (Gn 19,4; Js 6,21), e implica que o vigor da vida já passou. b) é um termo técnico para se referir ao ancião ou chefe da comunidade (Gn 19,4; Lv 19,32; 1Sm 28,24; Is 19,15[14]; 47,6). O segundo emprego da palavra está relacionado ao primeiro, uma vez que na cultura do AOM os homens mais velhos recebiam autoridade e liderança, em razão de acumularem sabedoria e experiência" (WEGNER, P. D., NDITEAT [vol. 1], p. 1107).

${ }^{264}$ SKA, J. L., Antigo Testamento: Temas e Leituras, p. 179.
} 


\section{2.}

\section{Seção B - Moisés ambienta a execução da ordem (vv. 10-11)}

\subsection{1.}

\section{A ordem é dada aos destinatários (v. 10ab)}

E ordenou-lhes Moisés,

$10 \mathrm{a}$

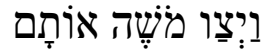

O grande líder está encerrando a sua missão. A estratégia pedagógica usada por Moisés, em seu último dia de vida, foi proferir diversos discursos. Esses discursos são exortativos, relembram os erros do passado e previnem sobre o que deve acontecer no futuro se o povo não cumprir a Lei, por isso Moisés é firme e ordena expressamente o que deve ser feito, a fim de agradar a YHWH.

A vida de Moisés está prestes a extinguir-se, portanto, compreende-se a urgência na atenção que deve ser dada aos seus últimos conselhos e ao cumprimento da Lei. ${ }^{265}$ Neste segmento o narrador enfatiza a ordem do líder: "e

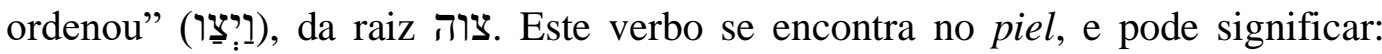
“ordenar, comandar, encarregar, designar, comissionar". ${ }^{266}$ A tradução escolhida para o verbo foi "ordenar", pois Moisés expressa, claramente, uma ordem importante e urgente.

O verbo צוה é encontrado cerca de 496 vezes no AT, sendo 487 vezes no piel e 9 vezes no pual. Mais da metade dessas ocorrências encontram-se no Pentateuco (252 vezes), majoritariamente concentradas no livro de Deuteronômio (88 vezes). Outra observação interessante é que dessas 496 vezes que o verbo é encontrado no AT, mais da metade dessas ocorrências têm YHWH como sujeito (280 vezes). Após YHWH, Moisés é o mais citado como sujeito do verbo (85 vezes) e logo a seguir vem Josué (14 vezes). ${ }^{267}$

\footnotetext{
${ }^{265}$ MANLEY, G. T., Novo Comentário da Bíblia, p. 25.

${ }^{266}$ WILLIAMS, T. F., צוה. NDITEAT [vol. 3], p. 772.

${ }^{267}$ Para WILLIAMS, T. F., (צוה. NDITEAT [vol. 3], p. 775): "Mais de dois terços das ocorrências

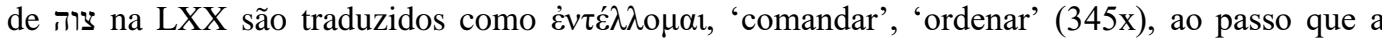
grande maioria restante é traduzida como $\sigma v v \tau \alpha ́ \sigma \sigma \omega$, 'ordenar', 'dirigir' ou formas correlatas (115 vezes). O verbo צוה é encontrado cerca de 50 vezes nos MMM (Manuscritos do Mar Morto) não bíblicos de Qumran (11 vezes em 1QS; 9 vezes em 1QDM; 5 vezes em 11QTemplo [todos de Deuteronômio]; 3 vezes em 1QHa; 1 vez em 1QSb, 1QLitPra e CD-A, e cerca de 18 vezes em vários MMM da caverna 4).
} 


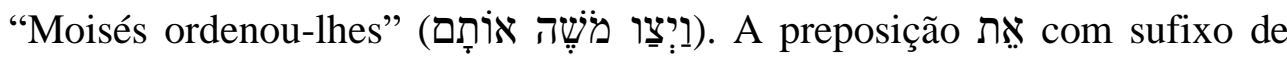
terceira pessoa do masculino plural אָוֹ , literalmente "a eles", que na oração funciona como o objeto indireto do verbo "ordenar", onde Moisés é o sujeito. Portanto, a ordem de Moisés está sendo direcionada aos sacerdotes, filhos de Levi, e aos anciãos de Israel, obrigando-os desde já com o compromisso pedagógico da leitura e instrução da Lei.

dizendo:

$10 \mathrm{~b}$ לאֶ.

O v. 10b, apresenta o infinitivo construto "dizendo" (לאמלר). É nesse ponto que se abre aspas para a ordem que será dada por Moisés. Essa ordem foi transmitida àqueles que são responsáveis pela instrução das famílias e das tribos: os anciãos. Também àqueles que são responsáveis pela instrução do povo: os sacerdotes. Eles deverão, em conjunto, com toda dedicação, interpretar a Lei e instruir a todos, assumindo, assim, o papel de Moisés como mestre e pedagogo.

Junto a saída de Moisés, há dois elementos chave que são muito importantes para a segurança do povo e sua entrada e permanência na terra prometida: 1) Um líder capaz e fiel a YHWH (o novo pedagogo); 2) A presença constante da Lei de YHWH (o material pedagógico). Portanto, se faz necessária a leitura periódica da Lei (a ação pedagógica). Seu propósito maior é a familiaridade com YHWH em função dos benefícios para o povo. ${ }^{268}$

Em Dt 27-28 encontramos as bênçãos e maldições estabelecidas por YHWH em conformidade com o que ficou estabelecido entre as duas partes YHWH e Israel - no que se refere ao acordo da aliança. Se por um lado YHWH oferece gratuitamente a terra de Canaã, como herança, e todas as bênçãos necessárias para uma vida próspera e feliz. Pode-se entender essa atitude de YHWH como uma estratégia pedagógica usada para motivar Israel a cumprir a Lei. Desta forma, não precisariam passar por dificuldades. Mas, por outro lado, como um bom pedagogo, YHWH, deve corrigir e punir toda forma de desobediência, para assim, contribuir na formação do caráter de cada membro de Israel, pois esta nação foi separada para ser sinal para todo o mundo.

${ }^{268}$ SÁNCHEZ, E., Comentário Bíblico Iberoamericano Deuteronomio, p. 441. 


\subsection{2.}

\section{O tempo e ocasião para a leitura da Lei (v.10c)}

"Ao final de sete anos,

$10 \mathrm{c}$

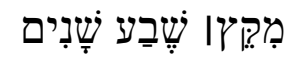
por ocasião do ano da remissão, na festa dos tabernáculos;

Ao final de sete anos, este foi o tempo determinado para se fazer a leitura solene da Lei na presença de todo o Israel. "Ao final de" como em Dt 15,1, no jejum que estabelece a festa dos tabernáculos (Lv 23,34), quando se apresentarem diante de YHWH. É evidente que a partir do contexto e conteúdo desses versos, além de Dt 31,24, que repete o v. 9, os versículos 10-13 estabelecem que a cada sete anos, durante a festa dos tabernáculos (Dt 16,16), no ano da remissão da dívida (Dt 15,1), se celebre um cerimonial de leitura da Lei em "o lugar escolhido por YHWH" (Dt 12,13-14; 31,11). ${ }^{269}$

O tempo e o lugar da leitura do livro da Lei ficaram claros. Isso teria lugar no fim do ano sabático (Dt 15,1-11); e durante o período da terceira peregrinação nacional, a festa dos tabernáculos. Tudo indica que esse período estipulado fosse para uma grande celebração de renovação da aliança e não apenas para a rotina da leitura e instrução da Lei. ${ }^{270}$

O tempo estabelecido é a cada sete anos, - ao final do ano sabático ${ }^{271}$ - para essa grande celebração diante de $\mathrm{YHWH}$, mas é claro que a Lei precisava ser ensinada diariamente, pois o povo de Israel não podia esquecer do seu Criador e libertador, aquele que transformou Israel em uma grande nação. Por isso, "a preocupação precípua do legislador é de que depois que ele tivesse ido às mansões eternas, a Lei fosse esquecida". ${ }^{272}$

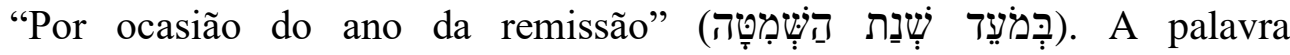

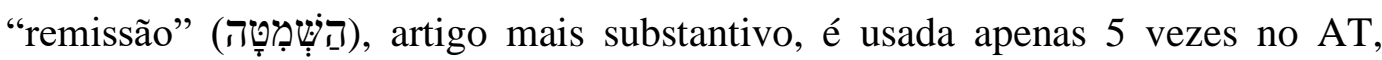

\footnotetext{
${ }^{269}$ AZCÁRATE, J. L. L., Deuteronomio, p. 278.

${ }^{270}$ CHAMPLIN, R. N., O Antigo Testamento Interpretado: Versículo por versículo, p. 154.

271 "A lei do sétimo ano ou do ano sabático aparece em três coleções de leis do Pentateuco: o Código da aliança (Ex 23,10-11), o Código deuteronômico (Dt 15,1-3) e o Código de santidade (Lv 25,2-8). Êxodo e Levítico concordam na substância das prescrições: a lei exige que a terra não seja cultivada, mas fique inculta no sétimo ano; como o homem e os animais, também ela deve ter um repouso sabático. A lei do sétimo ano em Dt 15,1-3, não concerne à terra e não fala de um sábado ou de um descanso; ele prescreve que as dívidas devem ser remitidas depois de sete anos" (McKENZIE, J. L., Sabático, ano. In: Dicionário Bíblico, p. 811).

${ }^{272}$ BENTHO, E. C.; PLÁCIDO, R. L., Introdução ao Estudo do Antigo Testamento, p. 161.
} 
sempre associada com a redução ou cancelamento de dívidas. O substantivo שִׁמִָּּה ocorre somente no livro de Deuteronômio, sempre com sentido de remissão de dívidas (Dt 15, 1-2.9. [no versículo 2 ocorre dois usos desta expressão] e 31,10). Era a Lei, o documento que determinava que a cada sete anos se devia desobrigar as pessoas das dívidas que tivessem contraído, era um lembrete contínuo de que as pessoas que haviam experimentado pessoalmente a graça de YHWH na remissão de seus pecados deviam, por sua parte, manifestar o espírito de graça em seus relacionamentos interpessoais, sendo também misericordiosos com seus irmãos. ${ }^{273}$

O v. 10c também enfatiza a festa dos tabernáculos. Tabernáculo, denominação que vem da Vulgata: tabernaculum, da tenda que na literatura sacerdotal forma o centro do santuário israelita no deserto. ${ }^{274}$ É o lugar sagrado onde se guardavam a arca e a Lei. Era uma espécie de templo móvel, construído a partir da ordem de YHWH a Moisés. Mas se tratava também de uma tenda, ${ }^{275}$ já que os israelitas se alojaram em cabanas durante o tempo de peregrinação no deserto.

O primeiro lugar da habitação de YHWH foi o tabernáculo ${ }^{276}$, a respeito do qual ele disse: "Faze-me um santuário, para que eu possa habitar no meio deles" (Ex 25,8). Foi esta a primeira morada de YHWH entre os seres humanos.

Interessante que o AT fala que YHWH descia para visitar Adão no Éden, quando, então, andava pelo jardim (Gn 3,8). Enoque e Noé andavam com o Senhor (Gn 5,24; 6,9), ao qual chamava Abraão de amigo (Is 41,8). Importante notar que YHWH estava presente na vida dessas ilustres personagens, mas nunca descera para habitar, somente para se relacionar. Em Gn 9,27, onde é profetizado: “Habitará nas tendas de Sem”, é possível que seja uma alusão ao tabernáculo.

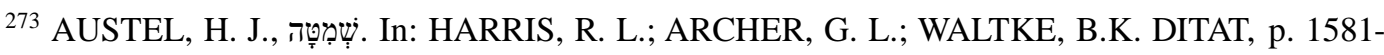
1582.

${ }^{274}$ BORN, V. D., Tabernáculo. In: BORN, V. D. Dicionário Enciclopédico da Bíblia, c. 1463.

275 "Tenda" (אד) אabitação de nômades (Is 38,12; Je 35,7; Os 12,10; Sl 125,5; Ct 1,5) e seminômades, como foram os patriarcas (Gn 13,5; 18,1; 26,5; 33,29; cf.31,33; Hb 11,9) e os israelitas antes de sua sedentarização em Canaã (Ex 16,16; Nm 19,14) (BORN, V. D., Tenda. In BORN, V. D. Dicionário Enciclopédico da Bíblia, c. 1485).

276 “A primeira menção na Bíblia da palavra tabernáculo está em Ex 25,9, onde YHWH instrui Moisés no Horeb/Sinai sobre a sua construção. Se pode dizer que o santuário é um ambiente espiritual, que o tabernáculo, o templo, ou até mesmo os corpos proporcionam à adoração a YHWH. E em alguns casos é referência ao edifício do próprio templo. Em Ex 25,8 está escrito: ' $\mathrm{E}$ me farão um santuário, e habitarei no meio deles'. YHWH dá a entender que não é uma construção de pedra que ele deseja. O que ele quer mesmo é um santuário no interior das almas, o que significa: 'E morarei dentro deles"” (PAGANELLI, M., Introdução ao Estudo da Tipologia Bíblica, p. 95-96). 
Durante mais de quinhentos anos, o tabernáculo foi sua habitação na terra, até dar instruções para Salomão construir para ele uma casa, e o Templo passou a ser seu santuário, pois “o palácio não será feito para homens, mas para o Senhor, o nosso Deus" (1Cr 29,1). ${ }^{277}$

A ordem de Moisés estabelece um tempo, o povo deverá se reunir de sete em sete anos para leitura da Lei. Esta leitura será feita na ocasião do ano da

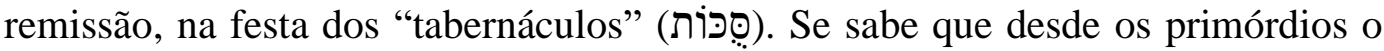
povo se relaciona com YHWH através da natureza. Oferece a YHWH as primícias do seu trabalho, como fruto da gratidão relativa ao cuidado de YHWH em suprir as suas necessidades. Esta relação entre YHWH e Israel passou a ser comemorada a partir das festas - tempos designados para se celebrar e comemorar - é a alegria de viver diante de YHWH. A festa serve tanto para louvar a YHWH, quanto para servir de estímulo e motivação para a aprendizagem da Lei. ${ }^{278}$

A vida cotidiana do Israelita, pastor e depois agricultor, determinou as diferentes festas. A festa da Páscoa era a festa pastoril da primavera, onde era oferecido as primícias do rebanho. O trabalho na terra fez nascer outras três festas anuais: ázimos na primavera, semanas no verão e colheita no outono (Ex 23,1417; 34,18.22). O livro de Deuteronômio uniu a Páscoa aos ázimos e deu à festa da colheita o nome de festa dos tabernáculos (Dt 16,1-17). É como se as festas fossem evoluindo e ganhando um sentido próprio para cada ocasião. Contudo, sem perder a sua essência.

Sendo assim, as festas tomaram um novo sentido em função dos eventos ocorridos na vida do povo e foram atualizando cada comemoração. Este novo sentido se dá em função do passado que elas lembram, do futuro que elas anunciam e do presente que elas revelam. Esta dinâmica estratégica de YHWH faz parte de sua pedagogia e está presente em diversos acontecimentos que unem o AT ao NT. Um evento marcante é a Páscoa do Egito (Ex 12) e a Páscoa cristã (Mt

\footnotetext{
${ }^{277}$ HABERSHON, A. R., Manual de Tipologia Bíblica, p. 53.

278 "A festa afirma a bondade do mundo, razão por que o homem pode usufruir dele, e porque Deus lhe dá o fundamento. Ela se organiza em torno de três polos interdependentes e correlatos: o homem, o mundo e Deus. O homem como sujeito bom, o mundo como objeto bom, e o divino como fundamento da bondade de um e de outro. É sobretudo este último, que a festa afirma e destaca: o mundo é bom e o homem pode habitá-lo como pátria, porque é fruto da vontade e da manutenção do sagrado e sobre o sagrado. Aqui se encontra o segredo de toda festa, na qual, para além das aparências, tomamos novamente consciência do valor positivo da existência, como espaço completo de usufruto e de sentido" (DI SANTE, C., Liturgia judaica, p. 211-212).
} 
26,17-29; Mc 14,12-25; Lc 22,7-20; 1Cor 11,23-34), aqui se encontra o memorial para se entender o sentido da festa.

Israel celebra seu Deus de diversas formas: como Criador é celebrado a cada sábado (Ex 20,11). O sábado é o sétimo dia no calendário israelita e judaico. Desde os primitivos tempos, o sábado é um dia sagrado para os judeus e é marcado pela observância religiosa. O substantivo שבשת está ligado a raiz, que significa repousar ou cessar. YHWH como libertador do Egito está presente não só no dia de sábado, mas também na celebração da Páscoa (Dt 5,12-15; 16,1). O ritual da Páscoa é apresentado em (Ex 12,1-28), onde está em relação com a festa dos ázimos. Js 5,10-11 relata a celebração da Páscoa por ocasião da entrada dos israelitas em Canaã. Já a festa dos tabernáculos lembra as marchas no deserto, o tempo em que viveram em tendas ( $\mathrm{Lv} 23,42 \mathrm{~s}) .{ }^{279}$

“Assim as festas agrárias se tornaram festas comemorativas e religiosas, pois na oração do israelita que oferece suas primícias eleva-se a ação de graças tanto pelos dons da terra como pelos altos feitos do passado (Dt 26,5-10)". 280

A festa dos tabernáculos ocorria no mês de tishri, que é o sétimo mês do calendário hebraico ( $\mathrm{Lv}$ 23,34.39), e que corresponde aos meses de setembro/outubro do nosso calendário. Sendo tishri o sétimo mês, era também o mês sabático. "O que o sétimo dia representa para semana, o mês de tishri é para o ano. Portanto, o primeiro dia do sétimo mês é celebrado como o 'sábado' (שָָּׁَِ), um dia de descanso, de memorial, de tocar as trombetas, e de santa convocação". 281

A festa dos tabernáculos era uma das três principais festas do judaísmo. Era celebrada no santuário central, em Jerusalém, para onde os fiéis peregrinavam. Todo varão israelita tinha obrigação de participar, mas a comunidade inteira acabava envolvida, pois, para o judeu, peregrinar a Jerusalém era uma festa. ${ }^{282}$

\footnotetext{
${ }^{279}$ McKENZIE, J. L., Páscoa/Sábado. In: Dicionário Bíblico, p. 696. 809.

${ }^{280}$ SESBOÜÉ, D.; LACAN, M. F., Festas. In: LEON-DUFOUR, X. Vocabulário de Teologia Bíblica, c. 350.

${ }^{281}$ MCMURTRY, G. S., As Festas Judaicas do Antigo Testamento, p. 109.

282 "Chegar à cidade santa era, sem dúvida motivo para festejar. Todo o seu ser era invadido por essa experiência. Ele esquece os numerosos obstáculos e perigos que enfrentou durante o longo caminho, pois seus olhos avistam e contemplam o monte santo de Deus: Sião" (FERNANDES, L. A.; GRENZER, M., Dança, Ó Terra, p. 163).
} 


\subsection{3.}

\section{A escolha do lugar (v. 11abc)}

quando for todo o Israel

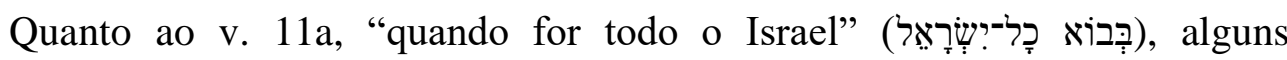
estudiosos argumentam que se todo o Israel fosse se apresentar diante de YHWH, a terra ficaria absolutamente vazia e descuidada. Possivelmente todo o Israel seria representado no lugar que YHWH escolhera, por um grupo simbólico de pessoas. ${ }^{283}$

Para os estudiosos, "somente os varões tinham obrigação de fazer esta viagem, embora suas famílias os acompanhassem. Não sabemos com qual precisão foi guardada essa prescrição". ${ }^{284}$

Como se pode observar no texto, Moisés não exclui ninguém, todos deverão se apresentar diante de YHWH, até mesmo o estrangeiro. Tamanha é a necessidade do conhecimento da Lei, pois o povo - a geração que nasceu no deserto - tinha ciência do que havia acontecido com a primeira geração - a que morreu no deserto - e não desfrutou da terra prometida, justamente porque não observou o decálogo entregue a Moisés no Horeb/Sinai. Havia real necessidade que todos comparecessem diante de YHWH, pois era de suma importância, ouvir a palavra para aprender a temer YHWH com amor e total reverência. ${ }^{285}$

Esta convocação para estar diante de YHWH em dia e local escolhido por ele, se tratava de uma convocação geral, mas não se restringia a um único dia para instrução. Exemplo disso, se tem em $\mathrm{Ne} 8$, onde Esdras reúne o povo sete dias seguidos para proclamar a leitura do livro da Lei.

Como se sabe, a instrução precisa ser diária, e deve começar na família. Este dia específico que foi convocado por Moisés, se torna um dia nacional, ou seja, Israel, como um todo, vai apresentar-se diante de YHWH, como nação e como uma nação eleita, para lembrar a unicidade: um só povo, um só Deus, uma única Lei, um único local de culto, uma única terra.

\footnotetext{
${ }^{283}$ THOMPSON, J. A., Deuteronômio Introdução e Comentário, p. 278.

${ }^{284}$ CHAMPLIN, R. N., O Antigo Testamento Interpretado: Versículo por versículo, p. 154.

285 'Para que todo o Israel 'ouça e tema', a ideia aparece nos seguintes textos: Dt 17,13; 19,20; 21,21; 31,12-13; e deve o presente texto implicar o princípio de que, sendo público o castigo, maiores são os efeitos produzidos" (MANLEY, G. T., Novo Comentário da Bíblia, p. 49).
} 
A unicidade é um tema teológico importante no livro de Deuteronômio, que produz um interessante conteúdo programático para prática pedagógica de YHWH, pois tudo gira em torno de um ponto central: o conceito de único (um). É através desse conceito que se desenvolve a ação pedagógica de YHWH, onde uma série de conteúdos importantes se entrelaçam nesta dinâmica utilizada por YHWH. ${ }^{286}$

Portanto, a convocação feita por Moisés em Dt 31,11a, era para "todo

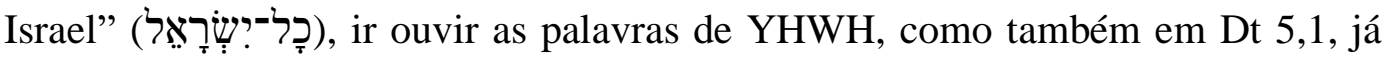
que se trata de um "povo santo" e "escolhido" (Dt 7,6). A frase "todo o Israel", é uma expressão que predomina no livro de Deuteronômio. ${ }^{287} \mathrm{O}$ v. 12a, reforça essa convocação e relaciona de forma detalhada os que deverão participar. Nesse versículo, está uma lista detalhada de todos que devem responder a esta convocação.

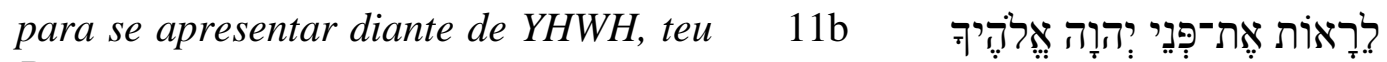
Deus,

No segmento 11 b o verbo "ver" (רָָָה), no infinitivo niphal לרָאוֹת denota o reflexivo do causativo, "se apresentar", ou seja, "deixar alguém ver". ${ }^{288}$ É estar na presença de YHWH, diante dele para prestar contas de suas obrigações que se resumem em obedecer e cumprir a Lei de YHWH na fidelidade e no amor, como está previsto na aliança. Assim sendo, o povo atenderá à vontade de YHWH e corresponderá à sua bondade, procedendo da seguinte forma: amando o seu criador, obedecendo a sua Lei, mostrando gratidão e temendo a YHWH. ${ }^{289}$

Nesse mesmo segmento $11 \mathrm{~b}$ se tem a presença do substantivo "deuses" (אֶלהתים), "que é um plural majestático, pois rebaixa a YHWH tudo o que era tido

\footnotetext{
${ }^{286}$ SCHMIDT, W. H., Introdução ao Antigo Testamento, p. 130.

${ }^{287}$ No livro de Deuteronômio existem várias palavras e frases que são repetidas para serem fixadas e apreendidas. Expressam ideias básicas do livro. Como: Israel "não deve esquecer" $(4,9)$, que foi "servo na terra do Egito" (5,15), muitas vezes chamado "casa de servidão" $(5,6)$, e que daqui o Senhor o "reuniu" $(7,8)$, "com mão forte e com braço estendido" $(4,34)$. Sobre o tema da herança, temos: Deus "dá" ao seu povo uma "boa terra" $(1,25)$, donde "mana leite e mel" $(6,3)$, como "jurara a seus pais" que a haviam de "possuir" $(1,8)$, como "herança" $(4,21)$. São muitas as expressões que existem no livro, citamos somente algumas. (MANLEY, G. T., Novo Comentário da Bíblia, p. 5).

${ }^{288}$ NAUDE, J. A., רָָָ. NDITEAT [vol. 3], p. 1004.

${ }^{289}$ WIERSBE, W. W., Comentário Bíblico Expositivo. p. 490.
} 
por divino". ${ }^{290}$ O substantivo significa "deuses ou deusas" no contexto do AOP. Neste segmento aparece acrescido do sufixo de segunda pessoa do masculino

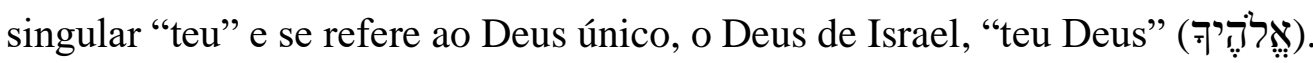

Há numerosas referências no livro de Deuteronômio a YHWH, o Deus de teus / nossos / vossos / seus pais. ${ }^{291}$ Este é o nome do Deus soberano que fez aliança com Israel. ${ }^{292}$

Há também, uma grande ênfase no uso do nome de Deus no livro, pois sabese que YHWH é o altíssimo e o seu nome carrega todo o seu poder. O nome é invocado em várias passagens e, é também, uma declaração de poder supremo capaz de tornar presente aquele que é invocado. ${ }^{293}$

O AT usa duas principais palavras para se referir a Deus. A primeira é "Deus" (אלדהים), que é o nome usado em Gn 1,1. Este substantivo ocorre 2.570 vezes no AT. É um termo genérico que significa, "Deus", quando está se referindo ao Deus de Israel. É interessante notar que esta palavra está no plural, e pode ser traduzida por "deuses", quando se refere aos deuses pagãos (Dt 4,7; 10,17;13,3), porém, quando se refere ao Deus de Israel, essa forma plural é sempre acompanhada por verbos e pronomes no singular. O outro substantivo é YHWH. Esse substantivo ocorre mais de 6.800 vezes e tem a função de nome pessoal de Deus. O nome YHWH, provavelmente, está relacionado ao verbo hebraico "ser/estar" (הָדיז) , por isso, a forma de se identificar a Moisés como, "Eu sou o que sou" (Ex 3,14). Esta forma, se trata, então, de um jogo de palavras, ainda que complexo, sobre o nome YHWH. ${ }^{294}$

no lugar que escolherá

$11 \mathrm{c}$

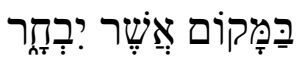

Em 11c se tem um verbo muito interessante e determinante no texto, é o verbo escolher; verbo este, que mostra uma das principais ações de YHWH. Na

\footnotetext{
${ }^{290}$ FERNANDES, L. A., Teologia, Antropologia e Ecologia em Gn 1,1-2,4a. p. 42.

${ }^{291}$ Dt $1,11.21 ; 4,1 ; 6,3 ; 12,1 ; 26,7 ; 27,3 ; 29,24$.

${ }^{292}$ THOMPSON, J. A., Deuteronômio Introdução e Comentário, p. 34.

${ }^{293}$ Segundo McKENZIE, J. L., (Nome. In: Dicionário Bíblico, p. 659): "Assim, seu nome é glorioso (Sl 72,19), grande (1Rs 8,42), terrível (Dt 28,58), exaltado (Sl 148,13). Através de seu nome se foi libertado (S1 54,3), exaltado (S1 20,2; 89,25). Confia-se em seu nome (S1 33,21; Is 50,10 ), encontra-se socorro em seu nome (S1 124,8). Golias se aproxima de Davi com lança e dardo, mas Davi se confronta com ele com o nome de YHWH (1Sm 17,45)".

${ }^{294}$ HAYS, J. D.; DUVALL, J. S., Manual Bíblico Ilustrado Vida, p. 65.
} 


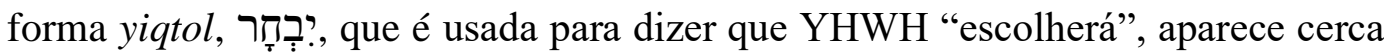
de 22 vezes no livro de Deuteronômio. ${ }^{295}$ Em todas as ocorrências é YHWH o

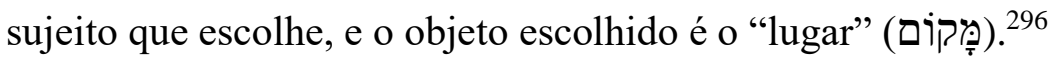

Este verbo cujo significado é: "colocar um olhar penetrante em" na maior parte dos contextos, a palavra sugere o conceito de "escolher" ou "selecionar". ${ }^{297}$ Visto que, é sempre YHWH quem escolhe, quem determina o lugar. Se pode, perceber que a centralização relativa ao local de culto tem direta relação com a unicidade de YHWH. ${ }^{298}$

No lugar que (este) escolher, a Lei será proclamada. Este, aqui, é YHWH. É ele quem escolhe o lugar. O lugar que futuramente será escolhido para unificar o culto será o santuário central - Templo de Jerusalém - que irá substituir os santuários mais antigos, espalhados em vários lugares. ${ }^{299}$

Interessante perceber que o código de leis específico de Dt $(12,1-16,17 *)$ Já trata dessa questão. Começa justamente tratando da substituição futura do tabernáculo por um santuário central como lugar onde YHWH escolherá para colocar o seu nome (Dt 12,4-32); eventualmente Jerusalém. ${ }^{300}$

Mas, nos primórdios, o local não era fixo, a leitura aconteceu em diversos lugares, sempre escolhidos por YHWH, para futuramente se fixar no Templo de Jerusalém, construído por Salomão. Apesar de Davi manifestar a vontade de construir uma casa para YHWH, ele não permitiu. Foi Salomão quem edificou essa casa, concretizando assim, o desejo de seu pai (1Rs 6,1-37).

${ }^{295}$ Dt 12,5.11.14.18.21.26; $14,23.24 .25 ; 15,20 ; 16,2.6 .7 .11 .15 .16 ; 17,8.10 ; 18,6 ; 23,17 ; 26,2$; 31,11 .

${ }^{296}$ MCCONVILLE, J. G., Deuteronomy, p. 293.

${ }^{297}$ Bíblia de Estudos Palavras-chave Hebraico e Grego, p. 1551.

298 "Quanto à identidade de YHWH, no Deuteronômio entrevê-se o percurso que levou a fé de Israel a amadurecer a tomada de consciência monoteísta. Para a tradição deuteronomística, YHWH é o único Deus de Israel. Afirmações como as de Dt 6,4-5 e 10,12.17, não vão além de uma perspectiva monolátrica e de uma indicação de tipo nacional. Embora conscientes da existência de múltiplas divindades, os israelitas são obrigados a adorar somente YHWH, seu Deus" (GALVAGNO, G.; GIUNTOLI, F., Pentateuco, p. 298-299).

299 "O santuário central unificou Israel em torno de uma única prática religiosa. No livro de Deuteronômio, esse lugar aparece sempre de maneira profética, sem nunca ser definido, ao passo que Jerusalém nunca é mencionada. Os críticos naturalmente veem no texto sagrado um anacronismo, supondo que o livro de Deuteronômio tenha sido escrito somente depois do estabelecimento do santuário central de Jerusalém" (CHAMPLIN, R. N., O Antigo Testamento Interpretado: Versículo por versículo, p. 154).

${ }^{300}$ FEE, G.; STUART, D., Como Ler a Bíblia Livro por Livro, p. 60. 
4.2.4.

A Lei deverá ser lida para todo o Israel (v. 11de)

proclamarás esta Lei,

$11 d$

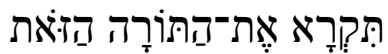

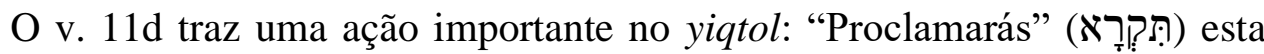
Lei, soando quase como uma ordem. O verbo pode designar levantar a voz, gritar ou também pode denotar ler em voz alta. Proclamarás a Lei, dá a impressão, que ela deve ser pregada para os quatro cantos da terra, por isso uma designação do verbo תִּקרָא, é gritar, pois todos devem saber, devem escutar, devem tomar conhecimento, ninguém pode ser impedido de ouvir. ${ }^{301}$

Dado importantíssimo é que o verbo "proclamarás" (תְְִּרָא), encontra-se na segunda pessoa do singular, "tu", isto implica que Moisés, nesse momento, não está falando com os sacerdotes, filhos de Levi, e anciãos, mas, provavelmente esteja falando com Josué, pois os discursos proferidos em Dt 31,1-30, se referem, praticamente, à sucessão de Moisés. Josué, então, devia estar ao lado de Moisés, recebendo toda a instrução.

Mas, a leitura da Lei também estava à cargo dos sacerdotes, filhos de Levi, e anciãos, aqueles que tinham o dever de ensinar e guardar os preceitos. "A lei não era algo vago, mas era expressamente codificada e, como texto escrito, veio a assumir uma autoridade extrema". ${ }^{302}$ A Lei escrita por Moisés se torna, por assim dizer, o livro didático daqueles que deverão estar à frente da função pedagógica de ensinar e educar dentro dos princípios estabelecidos por YHWH. Primeiramente, Josué, o novo líder, e depois, os sacerdotes e anciãos.

Uma vez sendo proclamada a palavra de YHWH, e essa sendo recebida no coração de cada membro da comunidade e vivenciada na vida de Israel, YHWH realiza, por assim dizer, sua tarefa pedagógica. Como expressa o profeta Is 55,11: “Assim é também a palavra que sai da minha boca: Não voltará a mim vazia, sem ter cumprido o que eu desejo e realizado o objetivo de sua missão”.

\footnotetext{
${ }^{301}$ Nota-se a ênfase que o livro de Deuteronômio dá ao verbo (19 ocorrências), pois o objetivo deste é que a Lei seja proclamada, para que conhecendo bem a vontade de YHWH, possam observá-la e praticá-la. "Proclamarás" (תרֶֶ), este verbo ocorre 730 vezes no AT (JENNI, E.; WESTERMANN, C., Theological Lexicon of the Old Testament, p. 1447).

${ }^{302}$ PAGANINI, S., Deuteronomio, p. 426.
} 
O primeiro lugar onde a Lei foi proclamada, depois da morte de Moisés, foi em Siquém. Josué como novo líder do povo terá o ofício de fazer valer a vontade de YHWH. Enquanto for líder, se encarregará de congregar o povo e fazer acontecer esse evento a cada sete anos. De acordo com Js 24,25-28, a leitura da Lei

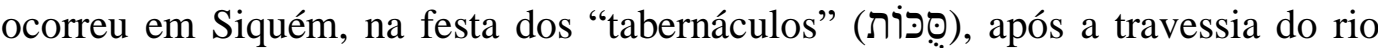
Jordão.

Moisés escreveu a Lei e Josué a leu na renovação da aliança de Siquém quando já estavam na terra prometida. Foi a primeira vez que esta leitura foi realizada. O livro, trazido junto à arca da aliança e que outrora foi entregue por Moisés aos sacerdotes e anciãos, agora é aberto e todos os que entraram na terra prometida puderam tomar conhecimento do seu conteúdo pedagógico-educativo.

Esse momento crucial da leitura da lei, curiosamente atesta na história de Israel pontos de convergências, que reportam aos antepassados, os patriarcas. Siquém ficava no estreito vale entre Ebal ao norte e Gerizim ao sul, e foi neste lugar que o patriarca Abraão ergueu o primeiro altar ${ }^{303}$ em honra de $\mathrm{YHWH}$, quando chegou à terra prometida, em Canaã, junto ao carvalho de Mambré (Gn 13,17-18).

Jacó, nesse mesmo local, comprou uma parte do campo dos filhos de Hamor após o seu retorno da Mesopotâmia e acampou com os seus familiares. Enterrou ali os ídolos trazidos pelos que o acompanhavam, combatendo a idolatria dentro do seu clã (Gn 33,18-20). Além disso, Jacó cavou um poço que tem o seu nome. Os estudiosos afirmam que foi neste local que o poço foi construído. ${ }^{304}$

Em Siquém, Josué convocou todo o povo de Israel a se apresentar diante de YHWH, conforme a ordem de Moisés em 31,12. Ali, também, proferiu um discurso, o seu discurso de despedida (Js 24,1-15). Se realizou nesta cerimônia a renovação da aliança (Js 24,25-28), exatamente no lugar onde ao entrar na terra prometida eles cumpriram a lei (Js 24,25), a Lei que foi estabelecida por YHWH e registrada no livro que Moisés entregou aos sacerdotes e anciãos.

\footnotetext{
303 “O altar é um elemento essencial do santuário e, nas histórias dos patriarcas, a edificação de um altar bastava para significar a fundação de um santuário (Gn 12,7-8; 13,18; 26,25; 33,20). O sacerdote era desde o início, e tornou-se cada vez mais, exclusivamente o ministro do altar" (DE VAUX, R., Instituições de Israel no Antigo Testamento, p. 444).

${ }^{304}$ A tradição está mencionada no NT e aparece no episódio da mulher samaritana (Jo 4,5.12).
} 
Para eternizar este momento solene foi colocada uma grande pedra debaixo do carvalho de Mambré, selando a aliança entre YHWH e o seu povo. Se pode dizer, que a pedra serviu como um recurso pedagógico concreto, para fixar na mente tudo que ocorreu ali, ela também serviu como o símbolo do testemunho, onde era selado os acordos, os tratados, as alianças e vários são os exemplos na Bíblia que ocorreram não só entre YHWH e o povo, mas também entre pessoas, grupos etc. ${ }^{305}$

Assim é apresentada a importância dessa cidade na história bíblica: foi em Siquém que pela primeira vez a ordem de Moisés foi executada. Onde a figura principal é Josué, seu sucessor, que assume, a partir de então, o ofício pedagógico do ensino.

A lei era de suma importância na vida de Israel, pois facilmente se desviavam do caminho do bem. "O propósito de Dt 31,9-23, mas especialmente da primeira parte Dt 31,9-13, é o da institucionalização do livro da Lei escrito por Moisés dentro da vida religiosa e das práticas cultuais de Israel". ${ }^{306}$ Este livro serviu como material didático a ser utilizado na formação das novas gerações, e o seu conteúdo pedagógico deverá ser ministrado e seguido por todos os responsáveis pela formação de Israel. É também, o contrato (acordo) da aliança entre YHWH e Israel.

Como se vê, a função cerimonial desta leitura da lei é religiosa e pedagógica (v.13), fruto de uma preocupação que aparece em outros lugares do livro: Dt 6,6$9 ; 11,18-21 ; 17,18-19)$. No entanto, há poucos detalhes sobre este cerimonial, e se realmente será cumprido fielmente conforme as determinações estabelecidas. ${ }^{307}$

Através do livro de Deuteronômio, se tem a informação que o livro da Lei ficou aos cuidados dos sacerdotes levitas, portanto, no Templo (Dt 17,18; 31,9), também, nas mãos dos anciãos $(31,9)$. São esses sacerdotes, filhos de Levi, e os anciãos, que devem se ocupar da instrução, desse livro, através da leitura pública (31,10ss). O que chama especialmente a atenção, é o que estabelece Dt 17,18: o rei, que já está sentado no trono e, portanto, exerce o cargo, deve fazer para si uma cópia do texto que está no Templo. E deve orientar-se por ele. O fato chama a

\footnotetext{
305 Veja alguns exemplos: O sonho de Jacó (Gn 28,18); tratado entre Jacó e Labão (Gn 31,44-48); conclusão da aliança (Ex 24,4); as doze pedras retiradas do Jordão (Js 4,3.8-9). Também os ossos de José foram trazidos do Egito e sepultados em Siquém (Js 24,32).

306 PAGANINI, S., Deuteronomio, p. 426.

307 AZCÁRATE, J. L. L., Deuteronomio, p. 279.
} 
atenção e certamente não é por acaso: pois, da mão do sacerdote o livro vai para a mão do rei que já governava. A partir desse episódio, surge aquilo que está relatado em 2Rs 22-23: o rei Josias promove uma grande reforma religiosa. ${ }^{308}$

É intrigante perceber que essa leitura do livro da Lei, a cada sete anos, não é atestada em nenhum outro lugar, nem mesmo nos regulamentos para o ano do jubileu. Dt 15,1; 16,13-15 atestam que ocorria na festa das tendas (סֶּכ). Uma hipótese é que essa legislação possa ter surgido graças à leitura periódica dos textos que continham tratados. ${ }^{309}$

Como se pode constatar, na Sagrada Escritura encontra-se relatado apenas três ocasiões, onde foi proclamada a leitura do livro da Lei. A primeira leitura foi realizada por Josué em Siquém, ${ }^{310}$ após a travessia do rio Jordão (Js 24,25-28), aproximadamente em 1210 a.C. A segunda leitura ocorreu na época do rei Josias (622/1 a.C.), durante a reforma do Templo foi encontrado um livro, tudo indica que era o livro da Lei, provavelmente uma parte do livro de Deuteronômio, respectivamente, o código da lei (Dt 12-26*). A terceira leitura foi feita por Esdras, após seu retorno da Babilônia. A leitura pública da lei foi proclamada numa praça em frente ao Templo de Jerusalém, em 457 a.C.

Como se pode perceber, os autores sagrados só mencionam a leitura do livro da Lei em quatro passagens bíblicas, sendo que no segundo livro de Reis e de Crônicas se trata do mesmo relato: Js 24,25-28; 2Rs 23,2/2Cr 34,30; Ne 8,1-5. É intrigante que um livro tão importante, sinal da aliança entre Israel e YHWH, fosse mencionado somente quatro vezes nos textos bíblicos. De qualquer forma, o fato de não ser citado inúmeras vezes, não significa que a leitura não estivesse sendo feita, já que o livro chegou até os dias atuais.

Como sacerdote, Esdras, não se preocupou em fazer sacrifícios no Templo, mas se preocupou em reunir o povo para ouvir, meditar e aprender a lei. O texto de Ne 8,1-8, apresenta Esdras congregando o povo para estudar a lei e para orar a

\footnotetext{
${ }^{308}$ CRÜSEMANN, F., A Torá, p. 377-378.

${ }^{309}$ BLENKINSOPP, J., Deuteronômio. In: BROWN, R. E.; FITZMYER, J. A.; MURPHY, R. E. Novo Comentário Bíblico São Jerônimo: Antigo Testamento, p. 248.

${ }^{310}$ Segundo FINKELSTEI, I.; SILBERMAN, N. A., (La Biblia Desenterrada, p. 102): "E Josué dirige uma cerimônia de renovação da aliança (Js 8,30-35). Ainda mais eloquente é a passagem em que YHWH ordena a Josué que medite sobre o 'Livro da Lei' dia e noite (Js 1,8-9), em um curioso paralelismo com a descrição bíblica de Josias como rei preocupado unicamente com o estudo da Lei, um rei que "se voltou para o Senhor de todo o seu coração, com toda a sua alma e força e em pleno acordo com a Lei de Moisés' (2Rs 23,25)”.
} 
YHWH. Na tradição do judaísmo, Esdras é considerado o fundador do grupo de escribas, que irão se ocupar do estudo da lei com o objetivo pedagógico de ensinar ao povo. ${ }^{311}$

Com Esdras e Neemias vai acontecer uma grande reforma religiosa, que foi iniciada com o rei Josias, mas interrompida devido a sua morte prematura. Esdras é um sacerdote descendente do sumo sacerdote Aarão. Se pode dizer que é um "novo Moisés", pois conhece bastante a Lei e a coloca em prática e, o mais importante, é que vai fazer o povo de Israel colocar a Lei em prática também. Assim como Esdras, Neemias encontra-se impulsionado a lutar pela reforma do culto. "Neemias, como Esdras, vem da diáspora para ajudar os repatriados na difícil tarefa de erguer Judá e Jerusalém. Por detrás da reedificação dos muros e da reinstalação do povo em Jerusalém, está o desejo de reedificar a fé”. 312

Sintetizando: Os porta-vozes e pedagogos que ministraram as leituras públicas da Lei foram, primeiramente, Moisés (Ex 24,3.7), quando recebeu o decálogo para instruir o povo que havia saído da escravidão do Egito; mais tarde, quando ele próprio, escreve o livro da Lei e recomenda a proclamação dessa leitura a cada sete anos (Dt 31,10-11), a partir de então, se tem a presença de: Josué (Js 8,34-35), Josias (2 Rs 23,2; 2 Cr 34,30) e Esdras (Ne 8,1-5). ${ }^{313}$ São estes os únicos registros que se têm do cumprimento da grande ordem de Moisés.

diante de todo Israel, aos ouvidos deles. $\quad 11 \mathrm{e}$

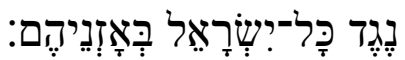

No v. 11e, Moisés como um bom pedagogo, tem a sensibilidade de solicitar, nas entrelinhas de seu escrito, que a leitura seja feita com toda a reverência para tocar no mais íntimo do ser, por isso usa uma expressão bem significativa, "aos

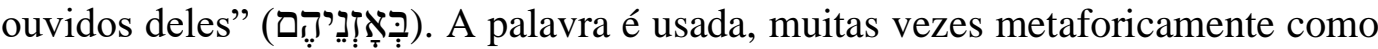
um instrumento de obediência $(\mathrm{Pv} 25,12)$ e de inteligência (Jó 12,11; 13,1; Pv 18,15; Ecl 1,8). Em Jr 6,10 os desobedientes ou desatentos são descritos como

\footnotetext{
311 O Templo foi finalmente reconstruído, por volta de 520 a.C., mas a cidade estava destruída e seus habitantes vivendo de forma precária. Foi quando Esdras retornou para promover um reavivamento da palavra de YHWH na vida daquele povo. Mas a retomada econômica veio somente em 444 a.C., com Neemias, que veio a Jerusalém para reconstruir suas muralhas e tornála novamente uma cidade importante (REINKE, A. D., Atlas Bíblico Ilustrado, p. 80).

312 FERNANDES, L. A., A Bíblia e a sua Mensagem, p. 173.

313 WATTS, J. W., Reading Law: The Rhetorical Shaping of the Pentateuch, p. 15-20.
} 
tendo ouvidos incircuncisos. A expressão hebraica para revelar alguma coisa ou tornar alguém ciente, é abrir os ouvidos (Rt 4,4; $1 \mathrm{Sm} 20,2.12 .13$; Is 35,5). ${ }^{314}$

O termo é muito sugestivo. Falar aos ouvidos reporta a questão da obediência, pois obedecer significa ouvir de perto, estar atento. Era preciso ir além do ouvir, ou seja, depositar no coração as palavras de YHWH: "Ponde no vosso coração" (Dt 11,18).

Moisés vai falar muitas vezes “do coração e ao coração". Por quê? Porque só com o coração se deve procurar (Dt 4,29), amar (Dt 6,5) e servir a YHWH (Dt 10,2). Circuncide-se, pois, o coração (Dt 10,16), já que dele procedem os maus pensamentos (Dt 9,4; 15,9). Mas recorde-se também que é no coração que reside a palavra de YHWH (Dt 30,14). ${ }^{315}$

Mais do que ouvir palavras mecanicamente, deve-se compreender profundamente o seu significado. E para isso é preciso ouvir com o coração, porque as nuanças das palavras da Torá não se encontram expressas explicitamente. Assim como aqueles que leem nas entrelinhas, deve-se ouvir nas entrelinhas. ${ }^{316}$

Portanto, falar "aos ouvidos deles" se trata de uma delicadeza de YHWH. É como se aquele que ensina falasse a cada um individualmente, de uma forma tão eficaz, que o contato do som das palavras com os órgãos da audição, trouxessem uma proximidade tão grande, capaz de fazer sentir a presença do próprio YHWH falando "aos seus ouvidos". 317

\footnotetext{
${ }^{314}$ Bíblia de Estudos Palavras-chave Hebraico e Grego, p. 1515.

${ }^{315}$ MANLEY, G. T., Novo Comentário da Bíblia, p. 44.

316 BUNIM, I. M., A Ética do Sinai, p. 605.

317 "A atividade psíquica é geralmente associada na Bíblia com vários órgãos do corpo. O principal deles e o mais frequentemente mencionado é o coração. Os antigos desconheciam a circulação do sangue e as funções fisiológicas do coração; mas as reações emocionais são facilmente reconhecíveis, e o coração é o centro principal da atividade emocional do corpo. Nossos planos ou propósitos encontram-se no coração (Is 10,7). O que nunca pensamos nunca entrou em nosso coração (Jr 7,31; 19,5). Assim o homem é o que o seu coração é.” (McKENZIE, J. L., Coração. In: Dicionário Bíblico, p. 183).
} 


\section{3.}

\section{Seção C - Ordem abrangente dada por Moisés (vv. 12-13)}

\subsection{1.}

Congregar Israel com uma finalidade específica (v. 12ab)

Congrega o povo:

$12 \mathrm{a}$

os homens, as mulheres,

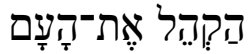

as crianças e o teu estrangeiro,

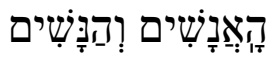

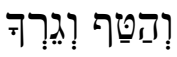

O v. 12a é aberto com um imperativo: “congrega" (הַקהָל). É a frase principal e estabelece o teor da ordem de Moisés, convocando a todos através de uma lista, em que a ordem é estabelecida por uma categoria de valores. Assim, fica estabelecido que todos devem participar da instrução da Lei, tendo a oportunidade de ouvir e conhecer os decretos que YHWH deu ao seu servo Moisés. Aqui se tem, novamente, a suposta presença de Josué ao lado de Moisés, pois o verbo está no singular e o seu sujeito oculto é o pronome "tu", indicando, assim, que possivelmente, a ordem de congregar, esteja sendo dada diretamente a Josué.

Moisés ordena que o povo se reúna, formando, assim, a assembleia de Israel (Dt 31,12.30), que aqui se detalha completamente: homens, mulheres, crianças e estrangeiros residentes; Dt 29,10 é de maneira mais extensa do que Dt 16,16; de onde unicamente são mencionados os varões. ${ }^{318}$

As palavras que convocam a futura assembleia de Israel para ouvir a leitura do livro são semelhantes àquelas com as quais YHWH pede a Moisés para convocar o povo ao santo monte em Dt 4,10. A lista dos participantes, embora menor amplia aquela de Dt 29,9-10, pois enfatiza a totalidade. As crianças escutam para aprenderem a temer, enquanto colocam em prática o que foi ouvido e que era reservado para os adultos. A insistência neste caso parece cair mais sobre o tema da transmissão da Lei, do que no fazer, por parte das crianças. Nos vv. 12a.13a, a indicação repetida das crianças como beneficiários da leitura referese à importância do ensino ministrado desde bem cedo, o que particularmente enfatiza Dt $6 .^{319}$

\footnotetext{
318 AZCÁRATE, J. L. L., Deuteronomio, p. 278.

${ }^{319}$ GRILLI, M.; PEREGO, G.; SERAFINI, F., Deuteronomio, p. 348-349.
} 
Até o estrangeiro fazia parte dessa lista de convocados, portanto, a cada ano sabático, na festa dos tabernáculos, a Lei deveria ser lida e explicada publicamente para todo homem, mulher e criança, quer fosse israelita quer fosse estrangeiro, de modo que todos ouvissem, temessem e lhe obedecessem (Ne 8). ${ }^{320}$

Como se vê, esta unidade está estruturada em torno do conceito de totalidade (vv. 9.11.13), nestes três versículos se têm a presença do substantivo

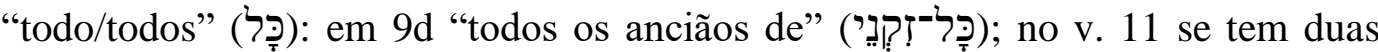
ocorrências em 11a/11e "todo Israel" (כָל־ישְׁרָרָל); no v. 13d "todos os dias que

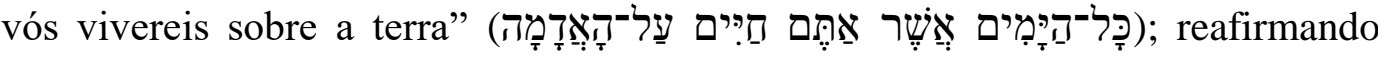
assim que a instrução de YHWH se dirige a todos os membros da comunidade, incluindo as futuras gerações. Neste sentido, é importante assinalar que a leitura periódica da Lei ajuda a geração adulta a recordar sua responsabilidade com YHWH, e a geração nova (as crianças), a ter a certeza de que a Lei sempre estará disponível para elas e para todas as gerações que se sucederão. A meta do conhecimento dessa Lei é o temor e a reverência a YHWH. ${ }^{321}$

De acordo com a legislação deuteronomista, os israelitas deveriam estudar o livro da Lei dia e noite e ensiná-los a seus filhos, mulheres e, até mesmo, aos estrangeiros (Dt 31,11-13; Js 1,8; S1 1,2). O teor pedagógico dessa instrução tem como metas a vida e as bênçãos para Israel. Se pode dizer, com propriedade, que algo que não faltou na ação metodológica de YHWH, quando ensinava a Israel, foi a sua misericórdia. ${ }^{322}$

que (está) dentro dos teus portões;

$12 b$

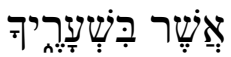

O estrangeiro é chamado de: “o 'teu' estrangeiro que (está) dentro dos teus portões". O carinho especial que YHWH tem pelos estrangeiros, pelos órfãos e

\footnotetext{
${ }^{320}$ WIERSBE, W. W., Comentário Bíblico Expositivo, p. 587.

321 “A leitura da lei tinha um propósito didático, o de infundir o temor e a decisão de observar, em todos os cidadãos de Israel, incluindo as mulheres e as crianças. Assim, as crianças ficavam sujeitas a essa influência benéfica. Além disso, os estrangeiros residentes também eram instruídos." (SÁNCHEZ, E. Comentário Bíblico Iberoamericano Deuteronomio, p. 441). "O Targum de Jonatham diz que todos tinham o dever de amar e honrar a lei, exaltando-a e renunciando à idolatria." (CHAMPLIN, R. N., O Antigo Testamento Interpretado: Versículo por versículo, p. 154).

322 “Não é por acaso, então, que Deuteronômio é o único livro do Pentateuco a usar a raiz do verbo

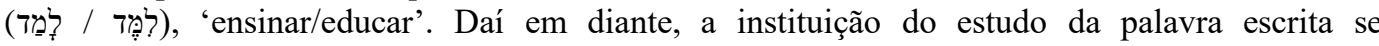
transformou em um conceito referencial em Israel" (ROITMAN, A. D., Bíblia, Exegese e Religião, p. 198).
} 
pelas viúvas revela-se de forma extraordinária nessas exortações professadas por Moisés. ${ }^{323}$ No livro de Deuteronômio se repete as palavras: órfão, viúva e estrangeiro muitas vezes. ${ }^{324}$ Por certo, foram conhecidas e seguidas por Boaz, um exemplo fora do livro de Deuteronômio que está no livro de Rt 2,15. ${ }^{325}$ E que também, deveria ser seguido por todos os israelitas, já que eles foram estrangeiros na terra do Egito. ${ }^{326}$

Quando Israel saiu do Egito e se transformou numa grande nação, conheceu horas felizes e horas amargas. Moisés insiste agora para que se ame o estrangeiro, em recordação dos maus dias passados no cativeiro. No entanto, eles (os estrangeiros), precisarão guardar o sábado (Dt 5,14) e as festas nacionais (Dt 16,11.14). Sendo assim, passam a pertencer à comunidade de Israel, tornando-se objeto de especial atenção, como o órfão e a viúva. ${ }^{327}$

As referências ao Egito marcam uma preocupação, pois enfatizam o zelo com o estrangeiro, já que o povo de Israel havia sido estrangeiro na terra do Egito e jamais poderia esquecer este fato. Experiência que se tornou um aprendizado. ${ }^{328}$ Por isso, uma frase muito usada no livro de Deuteronômio e muito importante na educação do povo era "lembra-te que foste escravo no Egito". Muitas foram as ocasiões que o povo foi exortado através desta frase. ${ }^{329}$

O livro de Deuteronômio enfatiza que Israel nunca se esqueça que foi estrangeiro e por isto trate bem o estrangeiro. Seria possível esquecer a opressão e

\footnotetext{
323 "Peregrinos e estrangeiros em Israel não deveriam ser oprimidos, e sim receber consideração especial por diversas razões: Israel sabia o que era ser estrangeiro, porque foram estrangeiros no Egito (Ex 23,9), estrangeiros tinham direito a interromper seu trabalho assim como os israelitas naturais (Ex 20,10) etc. Contudo, os peregrinos tinham que receber concessões especiais, porque não desfrutavam de todos os direitos de israelitas nativos. Os estrangeiros poderiam comer a Páscoa do Senhor somente se eles e toda a sua casa se submetessem à circuncisão (Ex 12,48-49)" (Bíblia de Estudo Palavras-chave Hebraico e Grego, p. 1584).

${ }^{324}$ Dt 14,29; 16,11.14; 24,17.19-21 26, 12-13; 27,19).

325 MANLEY, G. T., Novo Comentário da Bíblia, p. 67.

326 "A tríade social formada pelo estrangeiro, órfão e viúva, procura realçar, os aspectos econômico-sociais, evidenciando o grau de importância exercido por esses grupos humanos, profundamente atrelados ao modo de produção agropastoril, predominante nas sociedades antigas" (FRIZZO, A. C., A Trilogia Social, p. 27).

${ }^{327}$ MANLEY, G. T., Novo Comentário da Bíblia, p. 42.

328 Dt 1,27-30; 4,20.34.37.45-46; 5,6.15; 6,12.21-22; 7,8.15.18;8,14;9,7.12.26; 10,22;11,10; $13,6 ; 15,15 ; 16,1.3 .6 ; 17,16 ; 20,1 ; 23,5 ; 24,9.18 .22 ; 25,17 ; 26,5.8 ; 28,27.60 .68 ; 29,1.15 .24 ; 34,11)$. 329 Dt 5,$15 ; 10,19 ; 15,15 ; 16,12 ; 24,18.22$. Mais do que não esquecer era preciso também transmitir às futuras gerações. $\mathrm{O}$ verbo lembrar convida os descendentes de Israel a se voltarem para trás e olharem o passado. E não esquecerem os feitos e prodígios que YHWH fez na vida de Israel. Portanto, "lembra-te" é uma palavra muito importante no livro de Deuteronômio (15,5; $7,18 ; 8,2.18 ; 9,7.27 ; 15,15 ; 16,3.12 ; 24,9.18 ; 25,17)$. Os hebreus jamais poderiam esquecer os feitos de YHWH (BROWN, R., Entendendo o Antigo Testamento, p. 39).
} 
o sofrimento vivido no Egito até alcançar a libertação? Como esquecer as maravilhas que YHWH operou na travessia do mar de Juncos e a festa da Páscoa? Como não lembrar as graças de YHWH no Monte Horeb/Sinai? O maná que saciou a fome (Dt 8,3.16)? O rochedo de onde brotou água e saciou a sede de muitos (Dt 6,16; 9,22; 33,8)? ${ }^{330}$

O cuidado pelos que sofreram humilhação é um dos pontos mais acentuados do livro de Deuteronômio, visto que, YHWH olhou para o povo no cativeiro e agora espera que eles olhem para os desfavorecidos, inclusive "o 'teu' estrangeiro". Que contraste entre os códigos do Egito e da Babilônia. No Egito, os hebreus foram explorados numa vida de escravidão; na Babilônia tiveram oportunidade de trabalhar e progredir, também tiveram liberdade para cultuar o seu Deus, contudo, estavam fora de sua terra natal, em um cativeiro. Mas, no código da aliança com YHWH tudo é bem diferente: "Há uma espécie de generosidade na Lei de YHWH que não se pode encontrar em qualquer outro código humano". ${ }^{331}$ Porque YHWH é puro amor.

\subsection{2.}

\section{Para ouvir a Lei e aprender a temer a YHWH (v. 12 cde)}

para que ouçam

$12 \mathrm{c}$

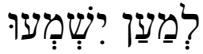

"Entre as conjunções mais importantes para expressar finalidade temos a forma conjunção está localizada nos segmentos $12 \mathrm{~cd}$ e foi traduzida pela expressão "para que", determinando a finalidade da leitura da Lei. ${ }^{333}$ A conjunção é especialmente usada para expressar finalidade, mas também, pode ser usada com valor consecutivo. ${ }^{334}$

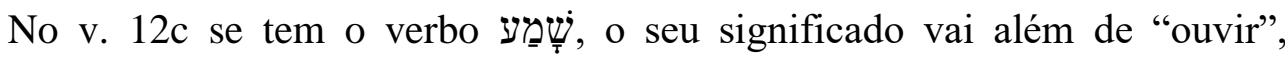
porque está se tratando da Lei de YHWH. Portanto, é ouvir com inteligência, com

\footnotetext{
${ }^{330}$ MANLEY, G. T., Novo Comentário da Bíblia, p. 25.

${ }^{331}$ MANLEY, G. T., Novo Comentário da Bíblia, p. 11.52.

332 JOÜON, P.; MURAOKA, T., Gramática Del Hebreo Bíblico, p. 676.

333 "Esta partícula pode ter valor causal, final ou consecutivo. Constrói-se com nome, pronome, com verbo infinitivo ou finito" (SCHÖKEL, L. A., לִ. In: Dicionário Bíblico HebraicoPortuguês, p. 391).

${ }^{334}$ JOÜON, P.; MURAOKA, T., Gramática Del Hebreo Bíblico, p. 678.
} 
implicação de atenção e obediência. O verbo encontra-se no yiqtol, terceira pessoa

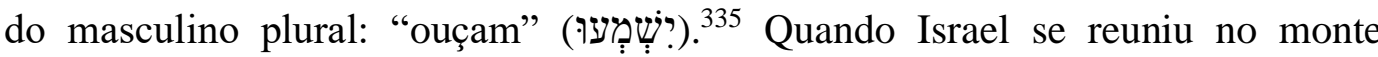
Horeb/Sinai, YHWH fez com que eles ouvissem as suas palavras (Dt 4,10). Foi o momento da primeira aliança, onde os Dez Mandamentos foram apresentados por YHWH ao seu povo como regra de vida.

O verbo basicamente significa ouvir, mas dependendo do contexto pode expressar várias conotações ao lado dessa acepção. O uso mais famoso desta

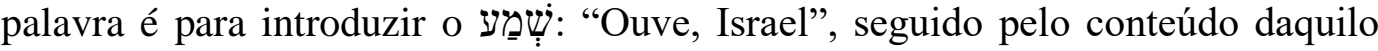
que os israelitas devem entender acerca de YHWH, seu Deus, e sobre como devem responder a ele (Dt 6,4). Em um uso paralelo, os céus são convocados: "Ouvi, ó céus!" A ordem é para os céus ouvirem a mensagem do profeta acerca de Israel (Is 1,2). A palavra chama a atenção para ouvir várias coisas: significa ouvir uma outra pessoa falando (Gn 27,6); a voz do Senhor (Gn 3,10); ou qualquer coisa que possa ser percebida com o ouvido. ${ }^{336}$

Mas a palavra ouvir também significa obedecer, ${ }^{337}$ ao passo que obedecer significa escutar de perto. De forma metafórica: encostar o ouvido na boca de quem fala para compreender exatamente o que está sendo dito. É preciso que as palavras penetrem a mente e o coração e lá fiquem fixadas, transformando a vida a partir do aprendizado, através de uma dinâmica pedagógica que só YHWH é capaz de realizar.

Nesse sentido, a Torá tornar-se uma sabedoria, uma crença e um estilo de vida, para tal é preciso a pureza nos corações e nas atitudes. Como revelação do desejo e planejamento do Criador, a Torá é a própria essência da pureza. As palavras da Torá devem ser "a nossa vida e a duração dos nossos dias". 338

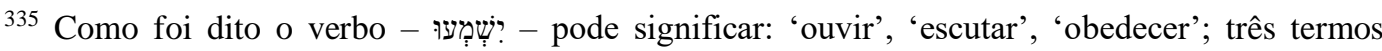
relevantes para o estudo e análise do texto em exposição. "O verbo empré é empregado cerca de 1050 vezes no qal, niphal, piel (duas vezes) e hiphil. Acham-se cognatos em acadiano, aramaico, árabe, ugarítico e etíope. A ideia básica é a de notar uma mensagem ou simplesmente um som. São sinônimos: qāshab (hiphil) 'dar atenção', 'estar atento'; 'āzan 'dar ouvidos' (um verbo

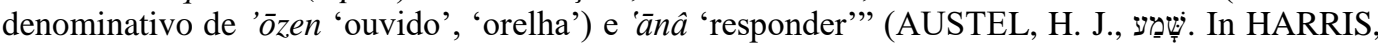
R. L.; ARCHER, G. L.; WALTKE, B. K. DITAT, p. 1586).

${ }^{336}$ Bíblia de Estudo Palavras-chave Hebraico e Grego, p. 1978.

${ }^{337}$ Segundo MANLEY, G. T., (Novo Comentário da Bíblia, p. 19): Alguns exemplos onde o verbo ouvir assume a conotação de obediência com certas construções no hebraico: Ele pode significar atender a um pedido ou ordem, como o pedido de Abraão a respeito de Ismael (Gn 17,20); o Senhor ouviu a oração de Agar e lhe concedeu um filho (Gn 16,11;30,6). O verbo significa obedecer em vários outros contextos (Gn 3,17; 22,18; Ex 24,7; 2Rs 14,11).

${ }^{338}$ BUNIM, I. M., A Ética do Sinai, p. 609.
} 
No v. 12d se tem o verbo ילדמִדוּ,., que no qal significa "aprender" e no piel “ensinar”. O verbo לִִ̣ no AT, indica a ação de ensinar e traduz a noção de treinar, bem como de educar. O ugarítico lmd significa "aprender/ensinar", e em acadiano lamādu tem o sentido de "aprender". ${ }^{339} \mathrm{Na}$ forma intensiva ou factiva, a raiz assume o significado de partilhar ensinamento. $O$ verbo significa, simplesmente, ensinar (2Cr 17,7-9) ou ensinar pessoas ou coisas; o Senhor ensinou ao seu povo $(\mathrm{Jr} 31,34)$ os seus decretos e leis (Dt 4,1). ${ }^{340}$

Embora o grego empregue duas palavras diferentes, ou seja, para "aprender" $(\mu \alpha v \theta \alpha v \omega)$ e para "ensinar" ( $\delta 1 \delta \alpha \sigma \kappa \omega)$, cada uma com conteúdo, objetivo e método próprios, o hebraico utiliza a mesma raiz para ambas as palavras, "porque toda aprendizagem e ensino repousa, em última instância, no temor do Senhor. Aprender com atenção, isto é acolher a vontade e a Lei de YHWH". 341

Aprender a temer a YHWH é o caminho para o bom êxito na vida. Assim

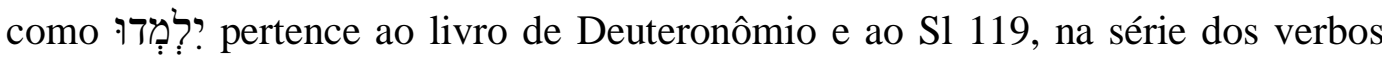
típicos para observar a Lei e aprender a temer a YHWH, como em Dt 4,10; 14,23; 17,19; 31,12s; da mesma forma S1 119,7.71.73, também enfatiza o aprender a Lei de YHWH e, principalmente, guardá-la no coração. ${ }^{342}$

Na práxis talmúdica, o menino torna-se um "filho do mandamento ou do

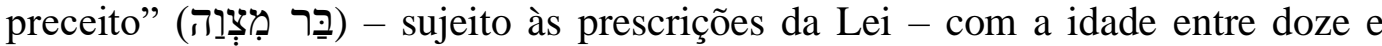
treze anos. ${ }^{343}$ A idade do serviço militar é fixada em vinte anos por $\mathrm{Nm} 1,3$. A educação e a instrução dos filhos é, totalmente, da responsabilidade dos genitores, constituía um dever tanto do pai como da mãe ensinar os filhos. Não havia uma instrução estabelecida antes da instituição da sinagoga. No período primitivo, a autoridade do pai era absoluta. ${ }^{344}$

Era dever dos pais, antes de tudo, ensinar às crianças a Lei de YHWH, pois nada lhes poderia ser mais útil, e, pela mesma razão, apresentar-lhes os

\footnotetext{
339 KAISER, W. C., לִִֵַ In: HARRIS, R. L.; ARCHER, G. L.; WALTKE, B. K. DITAT, p. 790791.

${ }^{340}$ Bíblia de Estudo Palavras-chave Hebraico e Grego, p. 1724

${ }^{341}$ KAISER, W. C., לִּמָד. In: HARRIS, R. L.; ARCHER, G. L.; WALTKE, B. K. DITAT, p. 791.

342 JENNI, E.; WESTERMANN, C., Theological Lexicon of the Old Testament, p. 832.

${ }^{343}$ Como é indicado também por Lc 2,42.

${ }^{344}$ McKENZIE, J. L., Filho. In: Dicionário Bíblico, p. 349.
} 
benefícios que são devedoras a YHWH e a maneira como foram libertas do Egito, a fim de que sejam gratas pelos favores do passado e, assim, possam receber outros no futuro. ${ }^{345}$

A Lei estabelece o dever dos filhos de honrar os pais (Ex 20,12; Lv 19,3; Dt $5,16)$; esse dever incluía o respeito e a obediência e era recompensado por uma longa vida. YHWH levou Israel como um homem leva o seu filho (Dt 1,31) e foi quem ensinou Israel a andar (Os 11,3). ${ }^{346}$ Assim sendo, se pode compreender que Israel passa a formar uma verdadeira família com seu Criador.

e temam a YHWH, o vosso Deus

$12 \mathrm{e}$

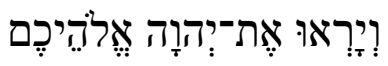

O v. 12e traz o verbo "temer" (יראוּ.) Temer no sentido de respeito e reverência, pois YHWH é um Deus de amor. Mas o não cumprimento da Lei poderia transformar esse temor em sentimento de medo e insegurança, pois YHWH se afasta do povo quando ele não é fiel à sua Lei (Dt 1,41-46).

$\mathrm{Na}$ pedagogia de YHWH existe bênçãos e maldições. YHWH, como Pedagogo, conduz Israel para uma vida repleta de bênçãos, mas esse povo obstinado e desobediente se desvia com frequência do cumprimento de suas obrigações diante da aliança com YHWH, com isso acaba atraindo para si as maldições.

A aliança, pode ser considerada, um recurso pedagógico que foi utilizado por YHWH, dentro da didática aplicada para a formação integral de Israel. A aliança lembra os antigos tratados hititas, mas apresenta uma questão primordial: "ser vassalo de YHWH era uma perspectiva impressionante, pois acarretava, na recompensa mais alta ou na condenação mais séria". 347

Obedecer a sua Lei é sinal de temor. O temor, porém, é a síntese da observância de todas as normas e preceitos de YHWH. A raiz verbal ירא em Lv 19,3, trata-se de temer os pais no sentido de respeito, honra, atitudes que indicam o sentido de obedecer (Pr 1,8). Em relação a YHWH se pode constatar que é o respeito que se manifesta na obediência à sua Lei.

\footnotetext{
345 JOSEFO. F., História dos Hebreus, p. 220.

${ }^{346}$ McKENZIE, J. L., Filho. In: Dicionário Bíblico, p. 349-350.

${ }^{347}$ ZUCK, R. B., Teologia do Antigo Testamento, p. 85.
} 
Este é o temor que YHWH espera de cada membro do seu povo. "E temam a YHWH, o vosso Deus", esta frase, estrategicamente, é repetida em diversos textos de Deuteronômio. ${ }^{348}$ Exigia-se um sentido de temor reverente e filial para com YHWH, assim como um sentimento de amor respeitoso ( $\mathrm{Lv}$ 19,3). O elemento do temor poderá desaparecer (Dt 9,9-13), o da reverência fica. ${ }^{349} \mathrm{O}$ temor é o ponto alto da pedagogia de $\mathrm{YHWH}$, é o ponto crucial para o pleno cumprimento da aliança. O temor se manifesta no reconhecimento da unicidade e da soberania de YHWH.

O propósito da leitura da Lei é tríplice e retoma temas característicos do livro do Deuteronômio: Ouvir, aprender e temer. É tudo que YHWH espera de Israel, sua obediência como prova de reverência e amor. ${ }^{350}$ Mas, em contrapartida Israel responde de forma negativa. ${ }^{351}$

Há um apelo ao aprendizado da Lei em conformidade com o temor a YHWH, temor este, que diante de um bom relacionamento se transforma em reverência. Aprender a temer a YHWH é o caminho para felicidade, e ao mesmo tempo, é o objetivo principal de todo processo de ensino-aprendizagem partilhado pelo maior Pedagogo da história: o Deus de Israel. ${ }^{352}$

\subsection{3. \\ Para observar a Lei (v. 12f)}

e observem $\quad 12 \mathrm{f}$

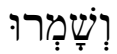

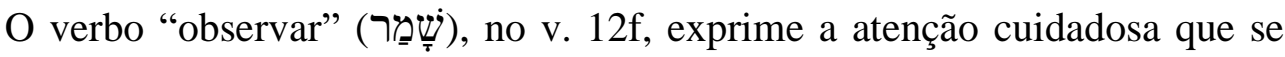
deve ter com as obrigações de uma aliança, de leis, de estatutos etc. Este é um dos

\footnotetext{
${ }^{348}$ Dt 6,$24 ; 8,6 ; 10,12 ; 14,23 ; 17,19 ; 28,58 ; 31,13$.

${ }^{349}$ MANLEY, G. T., Novo Comentário da Bíblia, p. 21.

${ }^{350}$ PAGANINI, S., Deuteronomio, p. 427.

${ }^{351}$ Segundo ROSE, M., (Deuteronômio. In: RÖMER, T.; MACCHI, J. D.; NIHAN, C. Antigo Testamento, p. 274): "A profunda desilusão no tocante à realização de uma obediência sincera $\mathrm{e}$ durável se exprime especialmente no motivo da 'dura cerviz', introduzido no Deuteronômio $(9,6.13 ; 10,16 ; 31,27)$ e amplamente desenvolvido no livro do Ex $(32,9 ; 33,3-5 ; 34,9)$ ”.

352 ' $E m$ várias passagens, 'temer' e ter uma vida correta estão intimamente ligados, pois são praticamente ideias sinônimas (Lv 19,14; 25,17; 2Rs 17,34; Dt 17,19). É bem possível que esse uso de 'temer' como virtual sinônimo de ter uma vida correta ou piedosa surgiu como resultado de ver o 'temor' - em todos os seus sentidos - como a motivação que produzia a vida justa" (BOWLING, A., ירא. In: HARRIS, R. L.; ARCHER, G. L.; WALTKE, B. K. DITAT, p. 655).
} 
empregos mais frequentes do verbo, "observar". ${ }^{353}$ Deve-se assinalar que a observância da Lei de YHWH não devia ser uma questão de mera teoria ou de obediência superficial. Com frequência se acrescenta a expressão "para cumprilas", como em Ez 37,24. ${ }^{354}$

Observar aqui também tem o sentido de guardar, pois a Lei deve ser guardada, principalmente, no coração. Ela deve ser cuidada e transformada em vida. Deve ser testemunhada, vivida e transmitida. Ouvir com o coração, é uma forma de expressar o modo, a partir do qual, se aprende verdadeiramente, e dessa forma, o entendimento daquele que aprende pode ir além. ${ }^{355}$

Também se pode interpretar a tradução "guardar" no sentido de cuidar da Lei, ou seja, literalmente, cuidar do livro físico. Era preciso preservar esse livro para as futuras gerações, esta era uma das funções dos sacerdotes. Seja no tabernáculo, seja no Templo, deviam cuidar do livro como sentinelas, preservando o material de qualquer tentativa de destruição. ${ }^{356}$

Sendo assim, o sacerdote que foi escolhido e designado para o serviço no santuário, tem também a função de guardião, e deve atuar como um guarda que vigia e que por meio do seu trabalho, impede o acesso de qualquer pessoa estranha ao tabernáculo ( $\mathrm{Nm} 3,38$ ), expondo, assim, o livro ao perigo. Seu serviço corresponde a guardar e proteger os objetos que somente eles podem manusear $\left(\mathrm{Nm} \mathrm{1,53;} \mathrm{3,28.32).} .^{357}\right.$

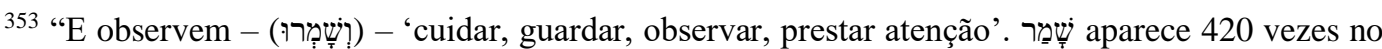
qal, 37 no niphal, 4 no piel e hitpael. O cognato acadiano shamāru significa: 'ser criado de', 'cuidar de'; o cognato fenício: 'vigiar', 'guardar'; o árabe samara: 'vigiar'. O sinônimo mais próximo é nātsar: 'vigiar', 'guardar', 'cuidar', 'observar', o qual é usado de forma bastante

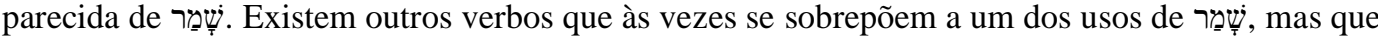
de outra forma são bem distintos" (HARTLEY, J. E., ששֵׁ. In: HARRIS, R. L.; ARCHER, G. L.; WALTKE, B. K. DITAT, p. 1587).

${ }^{354}$ Segundo HARTLEY, J. E., (שֵָׁ In: HARRIS, R. L.; ARCHER, G. L.; WALTKE, B. K. DITAT, p. 1588): "Em Pr 4,21, afirma-se que as leis de YHWH devem ser guardadas no coração. Ademais, usa-se a expressão não apenas para designar uma obrigação de obedecer a lei, mas também em referência ao desempenho de uma ocupação sagrada, tal como o sacerdócio (Nm 18,7)".

${ }^{355}$ BUNIM, I. M., A Ética do Sinai, p. 607.

${ }^{356}$ FREITAS, T., Análise exegética de Nm 18,1-7, p. 45.

${ }^{357}$ DE VAUX, R., Instituições de Israel no Antigo Testamento, p. 387.
} 


\subsection{4.}

\section{Para colocar em prática todas as palavras da Lei (v. 12g)}

para cumprir todas as palavras

desta Lei;
$12 \mathrm{~g}$

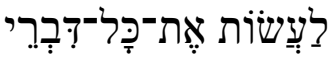

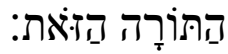

Para cumprir todas as palavras desta Lei: observar para cumprir, guardar para cumprir, sempre com a finalidade de pôr em prática a Lei deixada por Moisés. Esta afirmação é repetida várias vezes, como uma estratégia didática, facilitando o aprendizado através da assimilação e fixação do conteúdo da Lei. "Observai, portanto, para agirdes conforme vos ordenou YHWH, vosso Deus. Não vos desvieis, nem para a direita, nem para a esquerda" (Dt 5,32). ${ }^{358}$ Não adianta só cuidar e guardar, a Lei deve ser praticada e cumprida, transformando-se em vida. ${ }^{359}$

O v. $12 \mathrm{~g}$ utiliza uma forma enfática “todas" (כฺָּ), uma partícula muito comum na Bíblia, que ocorre aproximadamente 5.400 vezes no AT. À exceção de umas 800 vezes, todos os demais casos encontram-se numa relação genitiva com o termo seguinte, expressando, então, o sentido de "a totalidade de algo", como

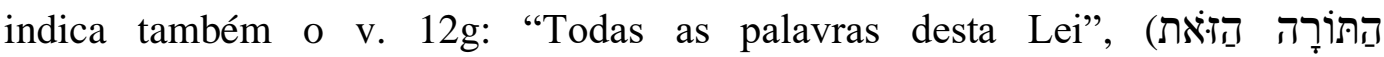

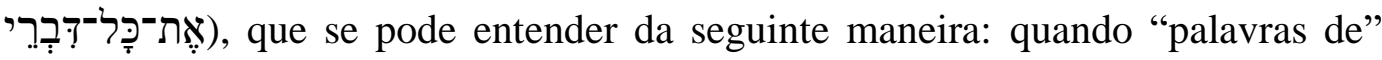

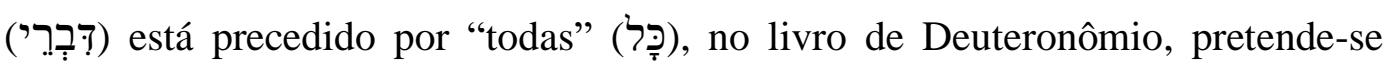
enfatizar a totalidade da Torá. ${ }^{360}$

Um exemplo é observado no S1 9,1, que é uma resposta ao Deus Todo Poderoso. Nele aparece, também, a partícula “todo/todos/toda/todas" (כְָָ), enfatizando o compromisso em celebrar de "todo" coração e contar "todas" as maravilhas de $\mathrm{YHWH}^{361}$

"Para cumprir" (לְעְשׁוֹת), além das inúmeras ocorrências com o sentido genérico de "fazer", frequentemente o verbo ע்ָָׁ é empregado com o sentido de obrigação ética. Muitas vezes o povo da aliança recebeu ordens para "fazer" tudo

\footnotetext{
358 A mesma frase ocorre em Dt $6,3.25 ; 7,11 ; 8,1 ; 11,22 ; 12,1 ; 13,18 ; 15,5 ; 17,10 ; 19,9 ; 24,8$; $28,1.15 .58 ; 31,12 ; 32,46$.

${ }^{359}$ MANLEY, G. T., Novo Comentário da Bíblia, p. 27.

${ }^{360}$ Dt 27,3.8; 28,58; 29,28; 31,12; 32,46 (OSWALT, J. N., כָּ. In: HARRIS, R. L.; ARCHER, G. L.; WALTKE, B. K. DITAT, p. 723).

${ }^{361}$ Também se pode lembrar das palavras de Dt 6,5, citadas por Jesus em Lc 10,27: “Amarás o Senhor teu Deus com todo o teu coração, com toda a tua alma, com toda a tua força e de todo o teu entendimento" (DOMERIS, W. R., לָ̦. NDITEAT [vol. 2], p. 656).
} 
o que YHWH havia ordenado (Ex 23,22; Lv 19,37; Dt 6,18 etc.). Os numerosos contextos em que ocorre esse conceito atestam a importância de uma reação ética favorável diante de YHWH, a qual vai além de uma mera abstração mental e que pode ser transformada em obediência visível mediante um ato palpável. ${ }^{362}$

\subsection{5. \\ Para que as futuras gerações conheçam a Lei (v. 13abc)}

e os filhos deles que não conhecem,

$13 \mathrm{a}$

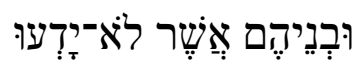

O v. 13a enfatiza que os que "não conhecem" a Lei de YHWH precisam conhecer, é fundamental que conheçam, pois ninguém ama o que não conhece. $\mathrm{O}$ texto está se referindo a segunda geração, pois a primeira, a dos pais terminou seus dias no próprio deserto. Para eles, foram concedidas inúmeras oportunidades e apesar de YHWH ter se revelado, não quiseram conhecê-lo. ${ }^{363}$ Então, YHWH, atendendo ao pedido de Moisés, dá mais uma chance, mas agora para os filhos, que precisarão corresponder às expectativas de YHWH, para isso é fundamental que conheçam e cumpram a Lei.

Como foi visto, a locução negativa, "não conhecerão" (לאיזידְעוּ), está determinando que os filhos ainda não conhecem, mas precisam conhecer. O verbo ִידְעוּ possui inúmeros significados, mas aqui tem o sentido de "conhecer para aprender". A Lei deve ser ensinada aos filhos, desde bem cedo.

O verbo corresponde a percepção sensorial, como: "ver", "saber", "conhecer" e toma um objeto direto que aponta diretamente para o sujeito sobre o que se percebe ou se sabe de alguma coisa. O conteúdo do que se percebe ou conhece, geralmente, é expresso na frase seguinte. ${ }^{364}$

\footnotetext{
${ }^{362}$ MCCOMISKEY, T. E., עָָׁׁ In: HARRIS, R. L.; ARCHER, G. L.; WALTKE, B.K. DITAT, p. 1179 .

363 "Os significados de ידע são difíceis de serem relacionados entre si. Eles variam da percepção sensorial para o processo intelectual, para habilidade prática, para atenção cuidadosa, para relacionamento íntimo e para intimidade física. A relação com outros verbos, nesse campo semântico, é difícil. É provável que a precisão na nuança não deva ser buscada em tais palavras isoladamente; apenas o contexto possibilita que algumas distinções surjam". (FRETHEIM, T. E., עיד. NDITEAT [vol. 2], p. 409).

364 JOÜON, P.; MURAOKA, T., Gramática Del Hebreo Bíblico, p. 630.
} 
“A visão precede o conhecimento". 365 Os dois órgãos, visão e audição, costumam acompanhar o verbo "conhecer" (ידע). Para conhecer é preciso ver e ouvir, como sugere a semântica do verbo. ${ }^{366}$ Na percepção intelectual, o coração é o lugar do conhecimento. Isso varia desde a noção básica até a percepção, a aprendizagem, o discernimento, a consideração cuidadosa e o bom julgamento. ${ }^{367}$

Ouçam

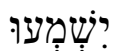

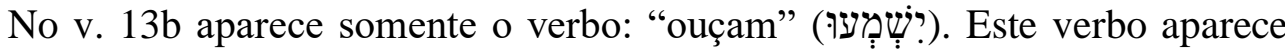
duas vezes no texto (vv. 12c.13b), indicando a importância de "ouvir" e reafirmando, insistentemente, o apelo de Moisés para que ouçam, e ouvindo aprendam, e aprendendo temam, e assim, cumpram os mandamentos de YHWH, pois no processo de ensino-aprendizagem é preciso ter uma pré-disposição ao aprendizado. É preciso ouvir atentamente para aprender, e aprendendo de coração, prestar toda a reverência que é devida a YHWH.

Importante perceber que no v. 13a acontece a mudança de sujeito, agora o sujeito passa a ser "e os filhos deles", e permanecerá como sujeito, também, dos

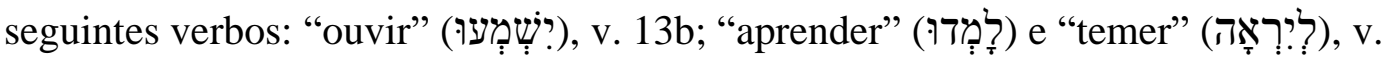
$13 \mathrm{c}$.

Como se sabe, o objetivo pedagógico e religioso do livro é construir a Lei na vida de Israel para perpetuidade, com o benefício adicional para aqueles que não conheceram a Lei anteriormente (v. 13a), pois não podem deixar de conhecêla. Os versículos 12 e 13 delineiam um objetivo educacional, resultando em diferentes padrões de comportamento. Acontece um diferencial: o grupo adulto no

\footnotetext{
${ }^{365}$ FRETHEIM, T. E., ידע. NDITEAT [vol. 2], p. 409.

366 "Importante saber que no AT a semântica do verbo conhecer vai além de um conhecimento intelectual: o conhecimento é obtido por meio da experiência, especialmente pela visão e pela audição. Isso assume uma capacidade auditiva e visual, tanto por parte de YHWH como por parte dos homens. Os verbos para visão geralmente precedem ידע; pois a visão precede o conhecimento. O inverso também é comum; pode ser um conhecimento que abre os olhos para se ver mais claramente. Os verbos para audição também precedem עיד', quer para YHWH, quer para os homens" (FRETHEIM, T. E., ידע. NDITEAT [vol. 2], p. 409).

367 "Contudo, o coração deve decidir se o conhecimento deve ou não ser obtido. Tal coração capacita a pessoa a incorporar as percepções dentro de um campo mais amplo de experiência e processá-las para propósitos de julgamento e de ação responsáveis. O coração compreensivo permite a avaliação e a ordenação das experiências de tal maneira que corresponda à vontade de Deus para a vida (Dt 4,39; 30,1). A percepção externa não levará ao conhecimento do valor, se o coração não estiver adequadamente afinado (Ex 7,23; 9,21)". (FRETHEIM, T. E., ידע. NDITEAT [vol. 2], p. 410).
} 
v. 12, incluindo os estrangeiros devem ouvir, a fim de aprender, temer e finalmente cumprir todas as palavras desta Lei, ao passo que no v. 13, seus filhos, que não conhecem, são obrigados apenas a ouvir e aprender a temer YHWH, talvez porque sejam menos responsáveis nesse estágio de vida (Dt 6,20-25). ${ }^{368}$

e aprendam a temer a YHWH, vosso 13c Deus,

No v. 13c aparecem novamente os verbos "aprender" e "temer" (ירָרָא / לְמָד enfatizando a importância de aprender a Lei, para assim, temer a YHWH com toda a reverência que a ele se deve dar; compreendendo os seus propósitos e cumprindo os seus mandamentos, agora se referindo "aos que não conhecem", aos filhos.

Nota-se que o v. 13c reitera as ideias dos versículos anteriores, embora salientando que era necessário que as crianças também recebessem a palavra. $\mathrm{O}$ coração dos filhos deve ser conquistado desde bem cedo, e o memorial especial da aliança seria uma excelente maneira de alcançar esse objetivo. Os filhos que não tivessem ainda conhecimento da Lei, conforme diz o texto sagrado, se mostrariam especialmente receptivos, evitando assim de se envolverem com a idolatria e com outros elementos do paganismo. Chegaria, assim, o dia em que os filhos herdariam a terra prometida de seus pais, e a continuidade da ocupação da terra estaria garantida, mediante uma educação religiosa dada desde a primeira infância. ${ }^{369}$

A vocação de Israel como uma nação separada para YHWH, devia dar testemunho da majestade e da glória de seu Senhor, em contraste com a degradante idolatria dos pagãos. ${ }^{370}$ Israel deveria manter a fidelidade ao Deus único, pois conhecia a Lei sobre as bênçãos e as maldições previstas para a desobediência. Conhecendo a Lei fica a escolha de cada um qual caminho tomar.

Assim Moisés, como bom mestre e pedagogo, pôde interpretar no livro de Deuteronômio a Torá sinaítica, também, seu sucessor Josué junto aos sacerdotes,

\footnotetext{
${ }^{368}$ WOODS. E. J., Tyndale Old Testamenty Commentaries, v. 5, p. 303.

${ }^{369}$ CHAMPLIN, R. N., O Antigo Testamento Interpretado: Versículo por versículo, p. 154-155.

${ }^{370}$ MANLEY, G. T., Novo Comentário da Bíblia, p. 22.
} 
e anciãos, depois de sua morte, puderam assumir a tarefa da interpretação e ensino da lei, e assim, contribuíram, também, como pedagogos, na formação de Israel. ${ }^{371}$

\subsection{6.}

Para praticar a Lei todos os dias da vida sobre a terra (v. 13d)

todos os dias

$13 d$

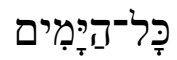

que vós vivereis sobre a terra,

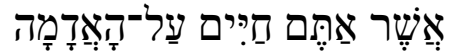

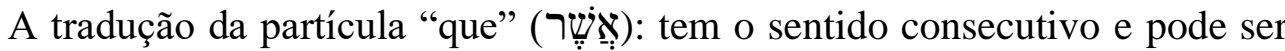
usada para juntar uma sentença secundária (v. 13d) a uma sentença principal (v. 13ab), mesmo quando não há verbo regendo um acusativo. ${ }^{372}$

No v. 13d, o substantivo plural חַיפים significa "vivos", "viventes", também pode traduzir a ideia de "vida" ou "duração da vida". É um plural de intensidade, ${ }^{373}$ que indica "vida, como uma ideia abstrata, significando o estado de estar vivo, em contraste com o estar morto. É a vida no que tem de melhor, é saúde, é vida sem fim". ${ }^{374}$ Por isso, foi interpretado como uma forma verbal, "vivereis", harmonizando o contexto da perícope e enfatizando, assim, a nova vida que será vivida na posse da terra prometida e que em conformidade com os preceitos de YHWH se torna uma vida sem fim. ${ }^{375}$

O substantivo "vivo", "vivente" (די) é usado frequentemente como epíteto de Deus (Js 3,10; Os 2,1; S1 42,3), mas também em relação aos homens, aos animais e a vegetação, em contraste com aquilo que está morto ou seco. ${ }^{376} \mathrm{O}$ plural do substantivo חַיפיפ é é uma palavra usada para se referir ao estado da vida em oposição ao da morte. Este significado acha-se em Dt 30,15: "Vês aqui, hoje te tenho proposto a vida e o bem, a morte e o mal". 377

חיה Na Torá, o verbo suas várias formas significa "vida", no sentido físico do termo. As pessoas, bem como as outras criaturas, vivem, sobrevivem, e

${ }^{371}$ OTTO, E., A Lei de Moisés, p. 96.

372 JOÜON, P.; MURAOKA, T., Gramática Del Hebreo Bíblico, p. 631.

${ }^{373}$ CHAVEZ, M., Diccionario de Hebreo Biblico, p. 172.

${ }^{374}$ YAMAUCHI, E., חירים. In: HARRIS, R. L.; ARCHER, G. L.; WALTKE, B.K. DITAT, p. 457. 375 "“Vivereis' também pode ter o sentido de vida eterna. Todas as palavras de YHWH nos sustentam, são como 'pão da vida' (Dt 8,3) que sustentam para a vida eterna (Mt 19,17; Jo 6,63)" (MANLEY, G. T., Novo Comentário da Bíblia, p. 19).

${ }^{376}$ YAMAUCHI, E., חים. In HARRIS, R. L.; ARCHER, G. L.; WALTKE, B. K. DITAT, p. 457.

377 VINE, W. E., Viver. In: Dicionário Vine, p. 333. 
são poupadas da destruição iminente. Em vários exemplos, tanto a forma nominal como a verbal contrastam com "morte". Vida e morte são vistas, claramente, como estados opostos. ${ }^{378}$

Olhando para Dt 30,19, onde se diz: "Hoje tomo os céus e a terra como testemunho contra vós: Eu te propus a vida ou a morte, a bênção ou a maldição. Escolhe, pois a vida, para que vivas tu e tua descendência”. Através desse texto, se pode entender o sentido de חַיִיים no v. 13d, que "vida" supõe "bênção", enquanto "morte" significa "maldição". Sendo assim, o termo חַ pode significar a duração da vida ou a vida enquanto bem-estar, na terra que será dada por YHWH. ${ }^{379}$

O substantivo feminino ${ }^{380}$ que significa lama, chão, terra, barro. No sentido restrito da palavra, designa a terra ou o barro que YHWH usou para formar o homem (Gn 2,7). O substantivo pode também carregar uma conotação universal, próximo do significado comum de אֶרְ: mundo (Am 3,2), à terra do Egito (Ex 10,6), a uma terra de exílio $(\mathrm{Am} 7,17)$ e, mais comumente, à terra de Israel (Ex 20,12; Nm 11,12; Dt 4,10.40). A maioria dessas referências pertencem a declarações que proporcionam longevidade na terra prometida. ${ }^{381}$

O substantivo pode também carregar uma conotação universal, próximo do significado comum de אֶר: mundo (Am 3,2), à terra do Egito (Ex 10,6), a uma terra de exílio $($ Am 7,17) e, mais comumente, à terra de Israel (Ex 20,12; Nm 11,12; Dt 4,10.40). ${ }^{382}$ A maioria dessas referências pertencem a declarações que proporcionam longevidade na terra prometida. ${ }^{383}$

Aos olhos do israelita, a terra prometida representava a manifestação mais clara da eleição de Israel; ela era, o dom da eleição divina e sua confirmação. Pode-se dizer, pela maneira de se apresentar a terra, que ela se torna "o país

\footnotetext{
${ }^{378}$ BRENSINGER, T. L., חיה. NDITEAT [vol. 2], p. 106.

379 ALONSO-SCHÖKEL, L., חיִים. In: Dicionário Bíblico Hebraico-Português, p. 215-216.

380 “A terra, (הָָָדָדָָה) 'terra', 'solo', 'chão'. Algumas traduções têm dificuldade de decidir qual a opção adequada em português. Originalmente, a palavra tinha o sentido de solo vermelho. A partir daí veio a denotar qualquer solo cultivado ou cultivável. Às vezes o termo aproxima-se do sentido de 'terra natal' (cf. Jn 4,2), ainda que provavelmente não em sentido político (embora haja casos como os de Is 14,2; 19,17 e especialmente a expressão quase exclusiva de Ezequiel, 'terra de

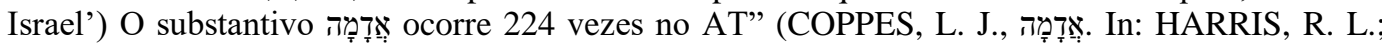
ARCHER, G. L.; WALTKE, B. K. DITAT, p. 14).

${ }^{381}$ GRISANTI, M. A., אְִָָ. NDITEAT [vol. 1], p. 262.

${ }^{382}$ Dt 5,16; 7,13; 11,9.21; 12,$1 ; 25,15 ; 28,11 ; 30,18.20 ; 31,13 ; 32,47 ;$ Jr 25,5 .

${ }^{383}$ GRISANTI, M. A., אִָּדָ. NDITEAT [vol. 1], p. 263.
} 
escolhido" por YHWH para seu povo. "Terra boa e vasta, terra que mana leite e mel" (Ex 3,8; Dt 26,9). ${ }^{384}$

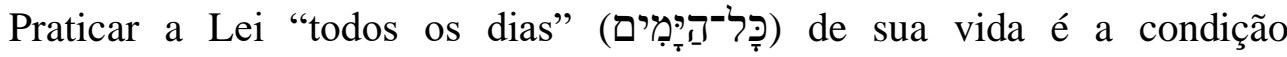
primordial para a bênção e a tranquilidade ao ingressarem na terra. Considerando o que havia sucedido à geração anterior, Moisés apela fervorosamente para Israel, a fim de que não cometa o mesmo erro, que guarde a Lei e a ponha em prática. Se obedecesse à Lei, viveria e tomaria posse da terra. ${ }^{385}$

\subsection{7. \\ Para tomar posse da terra prometida (v. 13ef)}

porque vós atravessareis o Jordão $\quad$ 13e

Porque vós “atravessareis” (עָבְרים) o Jordão. A raiz עבר 386 , pode ser usada para expressar o fato de que existe algum movimento entre dois lugares. Nessa categoria encontram-se as inúmeras referências a Israel quanto ao fato de atravessar o Jordão a fim de entrar na terra prometida. ${ }^{387}$

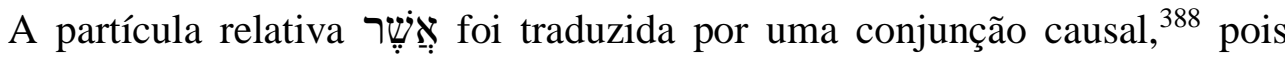
está ligada à oração anterior de onde se denota a necessidade de explicar a causa de "vivereis sobre a terra". Observe que as duas orações, seguem a mesma estrutura sintática, sendo que a partícula relativa "porque", pois se trata de uma oração coordenada sindética explicativa. Enquanto em 13d, se trata da partícula relativa "que", dentro de uma oração subordinada adverbial temporal.

\footnotetext{
${ }^{384}$ LÓPEZ, F. G., El Deuteronomio: uma ley predicada, p. 25.

${ }^{385}$ HOFF, P., O Pentateuco, p. 258.

386 "A ideia básica desse verbo é a de movimento; como regra, ele indica o movimento de uma coisa ou pessoa em relação a algum outro objeto que está parado, movendo-se ou motivando. Alguns têm dito que a tradução mais simples de é passar, mas na verdade isso não cobre os vários sentidos que עִ עִ pode trazer consigo. O verbo é empregado cerca de 550 vezes no AT" (VAN GRONINGEN, G., נִברבר. In: HARRIS, R. L.; ARCHER, G. L.; WALTKE, B. K. DITAT, p. 1070).

387 (VAN GRONINGEN, G., עָבָר In: HARRIS, R. L.; ARCHER, G. L.; WALTKE, B. K. DITAT, p. 1070)

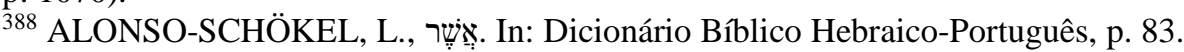


Como regra, as conjunções são usadas em várias combinações para introduzir cláusulas causais. As conjunções causais mais comuns são e ִ̣ e אִֶֶּ, que podem ser traduzidas por: "porque", "por conta do fato de que". 389

Como se vê as várias nuances da causalidade são geralmente expressas por meio de partículas relativas. A conjunção mais comum é ’’̣, mas a partícula relativa encontra numa oração que tem função explicativa. ${ }^{390}$

Aos olhos de Israel, a herança dada por YHWH - a terra - era uma manifestação clara do amor e da eleição divina. A terra possui um sentido profundo na fé e na vida do povo eleito. Em Dt 8,7-18 encontra-se uma das descrições mais importantes e uma das reflexões mais profundas de todo o AT sobre a terra. ${ }^{391}$

para ali, tomar posse dela.

$13 \mathrm{f}$

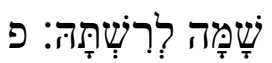

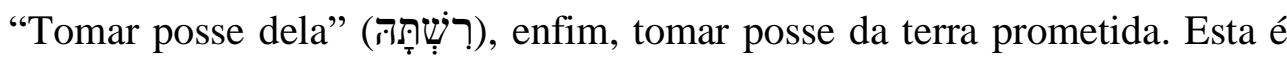
mais uma frase que estrategicamente é repetida inúmeras vezes no livro de Deuteronômio, com a finalidade de alcançar seu objetivo pedagógico. ${ }^{392}$ Faz parte da metodologia do livro de Deuteronômio, e ao mesmo tempo, é uma dinâmica pedagógica de YHWH nesse processo de ensino-aprendizagem a fixação do conteúdo a ser assimilado por completo.

A promessa foi feita a Abraão e agora a Israel, constava em estabelecê-los em uma terra, cuja meta principal do povo era reconquistar a terra da aliança que foi estabelecida entre YHWH e o patriarca Abraão. A terra onde mana leite e mel.

Quando Jacó e seus filhos partiram para o Egito devido a uma grande fome que assolou a região, eles eram apenas um grupo composto por setenta pessoas (Gn 46,27; Ex 1,5). Quatrocentos anos depois eles saem do Egito de volta à sua terra, agora formam uma nação, e saem do Egito com cerca de seiscentos mil

\footnotetext{
389 GESENIUS, H. F. W.; KAUTZSCH, E.; COWLEY, A. E., Gesenius' Hebrew Grammar, p. 492.

${ }^{390}$ JOÜON, P.; MURAOKA, T., Gramática Del Hebreo Bíblico, p. 679-680.

391 "Neste relato alternam-se uma série de fórmulas de tipo hínico com outras de caráter parenético, formando uma unidade com duas partes: a primeira (vv. 7-10) encontra-se delimitada pela expressão 'terra boa' e a segunda (vv. 11-18) inicia e termina com exortações paralelas a não esquecer (v. 11) e lembrar-se (v. 18) de YHWH” (LÓPEZ, F. G., O Pentateuco, p. 252).

${ }^{392}$ Dt 2,$31 ; 3,28 ; 4,1.5 .14 ; 6,1 ; 9,5.23 ; 10,11 ; 11,11.29 ; 23,21$.
} 
homens (Ex 12,37). "Como as estrelas dos céus!" (Dt 1,10), uma expressão de uso frequente para aludir à multiplicação extraordinária do povo de Israel, mas também se reporta a promessa feita a Abraão sobre uma grande descendência. ${ }^{393}$

No passado a aliança aconteceu com os patriarcas, agora, a aliança é feita através de Moisés no Horeb/Sinai e renovada em Moab com aqueles que irão tomar posse da terra, os nascidos no deserto.

O caminho se tornou longo e árduo devido a desobediência da geração que saiu do Egito. Eles estavam prestes a entrar na terra, mas vacilaram, duvidaram que conseguiriam enfrentar aqueles povos estrangeiros. Pensaram em suas próprias forças e esqueceram que à frente deles estaria YHWH. Sendo assim, foram punidos pela sua incredulidade e tiveram que retornar ao deserto, onde vaguearam por trinta e oito anos até toda aquela geração rebelde perecer. ${ }^{394}$

Chega, então, o momento decisivo do cumprimento da promessa. A travessia do Jordão, vai representar a porta de acesso à terra prometida (Dt 9,1-6). Diante de tudo que aconteceu desde a saída do Egito e os quarenta anos que Israel passou no deserto, percebe-se que esse evento só se concluiu por pura graça de YHWH. Pois se YHWH fosse levar em consideração tudo que Israel fez e agisse por sua justiça, Israel não possuiria a terra. Mas YHWH agiu pela fidelidade à sua própria palavra, cumpriu o que prometera. ${ }^{395}$

Por fim, depois de ver diversas características estratégicas presente na narrativa do livro de Dt, que se relacionam diretamente com Israel e com a pedagogia de YHWH, não se pode deixar de falar de uma característica que é muito importante: A sua orientação para o futuro. ${ }^{396}$ Isto além de incluir a geração que está prestes a entrar na terra, inclui também as futuras gerações (Dt 4,9.40).

Esse tema, em particular, gera tensão por todo o livro, entre a bondade divina ao trazê-los para essa boa terra e a consciência divina de que Israel, não obstante, fracassará. Desse modo, tanto no início quanto no fim do livro, há profecias quanto as maldições que cairão sobre o povo caso desobedeçam. Seu

\footnotetext{
${ }^{393}$ CHAMPLIN, R. N., O Antigo Testamento Interpretado: Versículo por versículo, p. 10.

${ }^{394}$ HAYS, J. D.; DUVALL, J. S., Manual Bíblico Ilustrado Vida, p. 110.

${ }^{395}$ LÓPEZ, F. G., O Pentateuco, p. 252.

396 “Moisés, como 'o primeiro e o maior profeta da longa sucessão de profetas', revelou este insight sobre o caráter de YHWH e a fragilidade do povo para que estabelecesse o padrão dos acontecimentos futuros. Ao lado disto, como outro dos profetas, ele tece indubitavelmente visões extáticas do futuro" (LIVINGSTON, G. H., Comentário Bíblico Beacon, p. 428).
} 
fracasso em cumprir sua parte na aliança resultará na perda da terra, e consequentemente em um novo exílio, ${ }^{397}$ mas o amor, grande atributo de YHWH, culminará na restauração de Israel, e consequentemente, em seu retorno à terra por meio de um "segundo êxodo". 398

Dt 30,1-3 é um forte apelo à conversão de Israel. Essas amorosas palavras de YHWH era justamente o que Israel necessitava ouvir na situação de exilados, já que haviam novamente, perdido a posse da terra. Pelo menos, decidiram preservar os ensinamentos pedagógicos - a Lei - como fonte de esperança num futuro melhor. Tudo deveria servir de advertência para as futuras gerações. Esses escritos ajudaram Israel a reconhecer o erro, preservar a fé e restabelecer o compromisso assumido na aliança, de seguir a Lei do grande Pedagogo: YHWH. Sendo assim, buscaram restaurar a sua identidade nacional, pois precisavam ser luz para o mundo. ${ }^{399}$

${ }^{397}$ Dt 4,25-28; 29,19-28; 30,1; 32,15-25.

${ }^{398}$ Dt 4,29-31; 30,2-10; 32,26-27.36-43 (FEE, G.; STUART, D., Como Ler a Bíblia Livro por Livro, p. 58-59).

${ }^{399}$ MILLER, S. M.; HUBER, R. V., A Bíblia e sua história, p. 35. 


\section{5 \\ Considerações finais}

O livro de Deuteronômio passou por um longo processo de formação até chegar à sua forma final e canônica. Um olhar para esse processo, mostra que, na sua base, estão tradições orais e escritas, coleções legais, narrativas parenéticas em forma de discursos exortativos. Ensinamentos foram registrados para não serem esquecidos e negligenciados. Nesse sentido, a Torá, concluída pelo livro de Deuteronômio, torna-se fonte de sabedoria que alimenta a fé e indica um estilo de vida, pois requer a pureza do coração e a retidão nas atitudes. Como revelação do desejo e planejamento do Criador, a Torá é a própria essência da pureza.

Do ponto de vista histórico, com o nascimento do judaísmo, a Torá passou a ter uma grande função pedagógica: formar as futuras gerações, a fim de que a experiência do exílio, marcada pela infidelidade e desobediência às leis e à voz dos profetas, não mais se repetisse na história. Admite-se que o conhecimento da Torá, devidamente assimilado, é capaz de determinar o comportamento do povo.

A legislação contida no livro de Deuteronômio expressa a vontade de YHWH que deve ser observada e obedecida. O livro, porém, não trata de um código judicial em si, mas coloca as leis em função da fé como obediência incondicional do povo a YHWH. As leis atestam ensinamentos que sugerem um estilo de vida diferente, que permite receber e desfrutar das bênçãos de YHWH. ${ }^{400}$

Com base nisso, deriva uma reflexão pessoal, pois se tem a pretensão de aprimorar o conhecimento através da Palavra de Deus e mostrar que ela pode ser um referencial diante de uma sociedade que parece viver distante de seu Criador, de seus propósitos e de seus ensinamentos. É preciso reaprender a sua mensagem, entender a sua pedagogia e reaplicar a sua dinâmica no ordinário da vida, para então contribuir na construção de um mundo mais justo e fraterno.

Ressalta-se, portanto, uma palavra de ordem: obediência. Sobretudo, devido aos aspectos que estão presentes em Dt 31,12 e são repetidos em Dt 31,13: a Lei dada por YHWH, através de Moisés, para que Israel a coloque em prática e viver feliz na terra de Canaã. Tais aspectos, são expressos pelos verbos: ouvir, aprender, temer, observar e cumprir. Esta foi a ordem dada por Moisés aos

\footnotetext{
${ }^{400}$ THOMPSON, J. A., Deuteronômio Introdução e Comentário, p. 13.
} 
sacerdotes, filhos de Levi, aos anciãos e, provavelmente, a Josué, pois, segundo a narrativa, a Torá seguiu com eles para Canaã, a fim de formar as futuras gerações; desta forma a Lei escrita, como elemento facilitador, é o livro didático, por excelência posto nas mãos de Josué e dos demais colaboradores.

Em Dt 31,11 está dito: "proclamarás esta Lei, aos ouvidos deles". Para a vida do fiel, a obediência a YHWH requer que se fale aos ouvidos; é uma essencial delicadeza do próprio YHWH, mas também, é uma delicadeza do fiel “inclinar seus ouvidos", numa atitude de escuta e obediência à voz do seu Deus.

YHWH é único (Dt 6,4), e, por sua unicidade, fundamenta-se a unicidade de Israel como povo escolhido e sujeito da obediência. Da aliança que se iniciou em Gn 32,28-30, que marcou a história dos pais (Dt 6,10.18), sai o fundamento da própria aliança estabelecida no Horeb/Sinai (Ex 20,22-23,19) e renovada em Moab (Dt 28,69-30,20).

A partir deste ponto de vista, a singularidade de Israel permite que se leia a aliança como um relacionamento que continua a se desdobrar ao longo do tempo e da história, na qual se destaca a fidelidade de YHWH à sua palavra e às suas promessas. YHWH nunca falha e não volta atrás mantém a sua fidelidade à aliança, ainda que Israel vacile. ${ }^{401}$

O livro de Deuteronômio, apresenta uma pedagogia de libertação, salvação e justiça, que foi estabelecida entre YHWH e Israel a partir do monte Horeb/Sinai. Esta aliança tem Moisés como o principal intermediário, cujo objetivo principal é estabelecer Israel como nação teocrática, tendo Canaã como pátria e como contrato a torá mediada por Moisés. ${ }^{402}$

Sendo assim, se verifica que o princípio básico do livro é histórico-salvífico, pois se caracteriza pela eleição e formação de um povo que, liberto da escravidão, foi chamado a ser sinal de conversão e salvação, não só para si, mas para os demais povos e nações. Ao escolher Israel como partner, YHWH lhe deu total responsabilidade sobre o seu futuro e uma missão diante da humanidade: "Israel como parte de sua vocação e destino, tem um papel importante no bem-estar do mundo". 403

\footnotetext{
${ }^{401}$ PAPOLA, G., Deuteronomio, p. 22.

${ }^{402}$ HARRINGTON, W. J., Chave para a Bíblia, p. 218.

${ }^{403}$ BRUEGGMANN, W., Teologia do Antigo Testamento, p. 568.
} 
E a terra de Canaã também foi escolhida como sinal, no qual o mundo teria, através dela, um vislumbre da soberania universal de YHWH. Sua conquista e ocupação serviriam como protótipo dessa soberania universal. YHWH é o Deus de toda a humanidade. Sendo assim, se compreende que "Israel foi chamado para agir no palco do mundo como uma nação que representava YHWH". ${ }^{404}$

Desta forma, o livro de Deuteronômio se apresenta como uma obra fortemente didática, motivada pelo desejo de ensinar/educar. Além disso, a sua pretensão didático-pedagógica tem como ponto de partida a aliança associada à Lei. Os discursos de Moisés, que representam o seu "testamento" e foram pronunciados em seu último dia de vida, dão ênfase à sua despedida que abre novos horizontes para o povo. Seu conteúdo consta de instruções pertinentes para que o povo prossiga a jornada, sob o comando de Josué, seu sucessor, e finalize o objetivo do projeto pedagógico formulado por YHWH.

A experiência vivida por Israel na formação de sua história como nação separada para YHWH, foi uma trajetória que representou uma grande "escola" de variados aspectos e aprendizados. Nessa longa formação, Israel passou por diversas experiências e adquiriu importantíssimas lições para sua jornada de vida na "nova terra". Israel precisou passar pela "escola" do êxodo, pela "escola" do deserto e pela "escola" da conquista de Canaã. Nessas "escolas", Israel aprendeu o sentido das suas escolhas, pontos importantes para assegurar a proteção da vida, as bênçãos do Deus da aliança e a felicidade de viver na presença de YHWH.

Israel teve tudo que era necessário para viver com dignidade, e teve o principal: era o povo eleito, separado para YHWH. Mas, mesmo assim, se desviava facilmente, se deixando conduzir por falsas concepções. Constantemente murmurava e se esquecia dos feitos de YHWH. Não faltaram orientações, leis, ensinamentos e exemplos - como os exemplos de seu ilustre líder Moisés capazes de conduzi-los ao aprendizado e ao crescimento como fiéis obedientes à vontade de YHWH e à sua aliança. A vida de Israel foi uma verdadeira "escola", onde era preciso estar sempre atento ao que YHWH queria ensinar, pois sempre ensina aos que estão com o coração aberto e dispostos a aprender.

A fé não consiste apenas em assentir diante de alguma doutrina. Antes de tudo, consiste na confiança que se deve ter em YHWH, e o bom êxito está na 
obediência. Os que morreram no deserto retratam a triste lembrança da falta de fé em YHWH, consequências da descrença e da recusa em obedecer às suas ordens e observar à sua Lei. ${ }^{405}$

A continuação dessa história permanece no hoje da vida de cada fiel, seja judeu ou cristão. A importância do estudo acadêmico acerca deste tema se reflete na vida prática de quem professa a fé em Deus e, significativamente, atestará o tipo de sociedade que existe ou está sendo gerada. Sabe-se que YHWH espera do seu povo a prática da justiça, da santidade, do respeito, da obediência e do amor.

Uma atenção para essa pedagogia pode servir de luz para compreender o mundo atual, no qual tantos falam de YHWH, mas na verdade, vivem longe dele. Não se trata de um ateísmo teórico, mas prático. Assim, a presença do tema da obediência é implacável para se acentuar que, apesar do ser humano não responder eficazmente ao projeto de YHWH e ao seu compromisso original, YHWH continua amando-o e, em sua divina soberania, continua formando o ser humano na humildade e sabedoria.

A contribuição que o tema pode trazer para o nível sociorreligioso é fundamental, pois o relacionamento - criador, criatura e mundo criado -, gera a harmonia de todas as coisas: uma ecologia integral. O viver bem, desejo original de YHWH para o ser humano, sempre exigirá, deste, purificação e conversão.

A voz de Moisés ainda ecoa nos ouvidos do povo hoje. O porta-voz de YHWH continua exortando a cada um, de forma particular, quando novamente se ouve a Palavra de YHWH sendo proclamada. É o próprio YHWH que convida para uma vida plena e harmoniosa em sua presença.

Dt 31,9-13 é, ao mesmo tempo, antigo e atual, pois: passado, presente e futuro, se entrelaçam na dinâmica do grande Mestre e Pedagogo, YHWH, e esta dinâmica nunca se torna ultrapassada, pois é sempre atualizada de forma pascal.

Para isso se faz necessário o respeito mútuo e principalmente a obediência a YHWH e à sua vontade; considerando os seus ensinamentos indicados, ao longo da história, através de seus escolhidos: patriarcas, Moisés, Josué, reis, profetas, até chegar na plenitude do tempo com o envio do seu próprio Filho: Jesus, confessado Cristo, Servo obediente por excelência, plenitude e finalidade da Lei $(\mathrm{Rm} 10,4)$.

${ }^{405}$ CHAMPLIN, R. N., O Antigo Testamento Interpretado: Versículo por versículo, p. 14. 
Anexos

Anexo 1: Quanto ao uso do verbo na terceira pessoa

\begin{tabular}{|c|c|c|c|c|}
\hline Verbo & Tradução & $2^{\mathrm{a}}$ Pessoa & $3^{\text {a }}$ Pessoa & Infinitivo \\
\hline נַיכְרְּרב & e escreveu & & $\mathrm{X}$ & \\
\hline בוְּּתוּנָהּה & e a deu & & $\mathrm{X}$ & \\
\hline 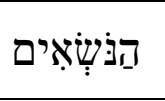 & $\begin{array}{l}\text { os que levam } \\
\text { (Particípio) }\end{array}$ & & $\mathrm{X}$ & \\
\hline נָּתון & $\begin{array}{c}\text { deu } \\
\text { (verbo implícito) }\end{array}$ & & $\mathrm{X}$ & \\
\hline בוּיְֵַו & e ordenou & & $X$ & \\
\hline לֶאמֵָר & Dizendo & & & $\mathrm{X}$ \\
\hline & quando for & & & $\mathrm{X}$ \\
\hline לִרְאוֹת & $\begin{array}{c}\text { para se } \\
\text { apresentar }\end{array}$ & & & $\mathrm{X}$ \\
\hline יִבְחָרִ & Escolherá & & $X$ & \\
\hline דְְִּרָא & Proclamarás & $\mathrm{X}$ & & \\
\hline הַקְהַל & Congrega & $\mathrm{X}$ & & \\
\hline דָדיה & $\begin{array}{c}\text { Está } \\
\text { (verbo implícito) }\end{array}$ & & $\mathrm{X}$ & \\
\hline יִשְׁמְמעוּן & Ouçam & & $X$ & \\
\hline יִלְמְדוּוּ & Aprendam & & $\mathrm{X}$ & \\
\hline וְירָאוּן & e temam & & $\mathrm{X}$ & \\
\hline וֹשְָׁמרוּו & e observem & & $X$ & \\
\hline לַעְשוֹוֹת & para cumprir & & & $X$ \\
\hline דִיְדעוּוּ & Conhecem & & $X$ & \\
\hline ישָשְמָעוּ & Escutem & & $\mathrm{X}$ & \\
\hline וְלְמְדוּוּ & e aprendam & & $\mathrm{X}$ & \\
\hline לִירְאָה & $\begin{array}{l}\text { a temer (com } \\
\text { sufixo de } 3 \mathrm{FS} \text { ) }\end{array}$ & & $\mathrm{X}$ & $\mathrm{X}$ \\
\hline חַיִים & $\begin{array}{l}\text { Vivereis } \\
\text { (Particípio) }\end{array}$ & $\mathrm{X}$ & & \\
\hline עֹבְרִים & $\begin{array}{l}\text { Atravessareis } \\
\text { (Particípio) }\end{array}$ & $\mathrm{X}$ & & \\
\hline לְרְשְׁתָהּה & $\begin{array}{l}\text { tomar posse dela } \\
\text { (com sufixo de } \\
\text { 3FS) }\end{array}$ & & $\mathrm{X}$ & $\mathrm{x}$ \\
\hline
\end{tabular}




\section{Anexo 2: Formação do livro de Deuteronômio segundo a "Escola Deuteronomista" ${ }^{406}$}

\begin{tabular}{|c|c|c|c|c|}
\hline $\begin{array}{c}\text { Escola } \\
\text { Deuteronomista }\end{array}$ & $\begin{array}{c}\text { Três } \\
\text { Períodos }\end{array}$ & Datação & Composição & Algumas Referências \\
\hline \multirow[t]{3}{*}{$1^{\mathrm{a}}$ EDIÇÃO } & \multirow[t]{3}{*}{$\begin{array}{l}\text { Antes do } \\
\text { Exílio } \\
\text { (A partir } \\
\text { de } 620 \mathrm{a} \text {. } \\
\text { C.) }\end{array}$} & $\begin{array}{c}\text { Parte mais } \\
\text { antiga. } \\
\text { Provavelmente } \\
\text { algum material } \\
\text { deve remontar } \\
\text { ao tempo de } \\
\text { Moisés, } \\
\text { passando por } \\
\text { juízes até Reis. } \\
\text { (Sécs. XIII - } \\
\text { IX a.C.) }\end{array}$ & $\begin{array}{c}\text { 12-26* } \\
\text { (Código } \\
\text { Deuteronômico } \\
\text { = núcleo } \\
\text { primitivo) } \\
\text { Dt 31,9-13, } \\
\text { pertence à } \\
\text { primeira edição } \\
\text { do livro de } \\
\text { Deuteronômio. } \\
\text { Aqui é a lei (o } \\
\text { Código } \\
\text { Deuteronômico) } \\
\text { que servirá de } \\
\text { testemunho } \\
\text { contra Israel (v. } \\
\text { 26), caso ele se } \\
\text { revolte contra } \\
\text { YHWH. }\end{array}$ & $\begin{array}{c}\text { A primeira edição da } \\
\text { História } \\
\text { Deuteronomista } \\
\text { abarca o período que } \\
\text { vai de Salomão até } \\
\text { Josias. } \\
\text { (900 - } 600 \text { a.C.) }\end{array}$ \\
\hline & & $\begin{array}{c}\text { Reforma de } \\
\text { Ezequias } \\
\text { (715-687 a.C.) } \\
\text { (Sécs. VIII - } \\
\text { VII a.C.) }\end{array}$ & $\begin{array}{c}5-11+\text { parte } \\
\text { dos capítulos } 26 \\
-27 \text { e }+ \text { os } \\
\text { capítulos } 28- \\
29 .\end{array}$ & $\begin{array}{l}\text { Durante o reinado de } \\
\text { Ezequias } \\
\text { (complementos que } \\
\text { foram anexados } \\
\text { posteriormente) }\end{array}$ \\
\hline & & $\begin{array}{c}\text { Reforma de } \\
\text { Josias } \\
\text { (640-609 a.C.) } \\
\text { (Séc. VII a.C.) }\end{array}$ & $1-4$ & $\begin{array}{c}\text { Introdução da época } \\
\text { do rei Josias } \\
\text { (complementos que } \\
\text { foram anexados } \\
\text { posteriormente) }\end{array}$ \\
\hline $2^{\mathrm{a}}$ EDIÇÃO & $\begin{array}{l}\text { Durante o } \\
\text { Exílio }\end{array}$ & $\begin{array}{l}\text { 586-538 a.C. } \\
\text { (Séc. VI a.C.) }\end{array}$ & $\begin{array}{l}\text { A } 2^{\mathrm{a}} \text { edição não } \\
\text { contém textos } \\
\text { do livro de } \\
\text { Deuteronômio }\end{array}$ & $\begin{array}{c}\text { A segunda edição } \\
\text { abarca desde o tempo } \\
\text { da conquista de } \\
\text { Canaã até o exílio. } \\
\text { (Js, Jz, Sm, Rs) }\end{array}$ \\
\hline
\end{tabular}

${ }^{406}$ STORNIOLO, I. Como ler o livro do Deuteronômio. p. 30-31. PAPOLA, G. Deuteronomio. p. 15-20. AZCÁRATE, J. L. L. Deuteronomio. p. 24-25. LUZA, N. Uma Introdução ao Pentateuco. p. 49. 


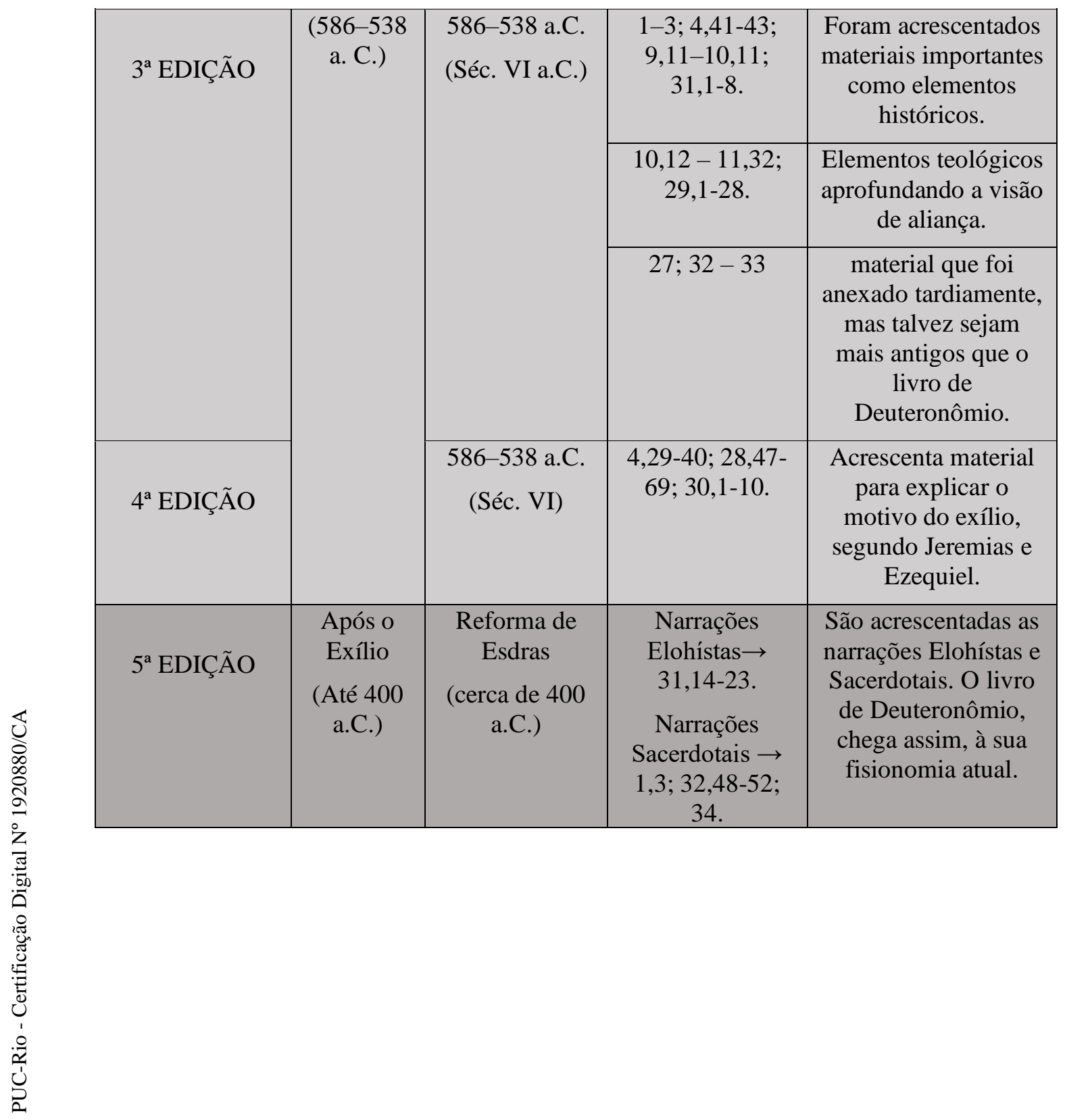


Anexo 3: Citações e alusões do texto de Dt no NT407

\begin{tabular}{|c|c|c|c|}
\hline Deuteronômio & Tema & $\begin{array}{c}\text { Novo } \\
\text { Testamento }\end{array}$ & $\begin{array}{l}\text { Tipo de } \\
\text { referência }\end{array}$ \\
\hline Dt 1,7 & O grande rio Eufrates & Ap 9,14 & Alusão \\
\hline Dt $1,9-17$ & Tribunal terrestre e juízo divino & 1 Cor 6,1-6 & Alusão \\
\hline Dt 2,14 & Trinta e oito anos & Jo 5,5 & Alusão \\
\hline Dt 3,11 & Unidade de medida & Ap 21,17-18 & Alusão \\
\hline Dt $4,1-2$ & Fórmula do cânon & Ap 22,18-19 & Alusão \\
\hline Dt 4,11-12 & Descrição da teofania & $\mathrm{Hb} 12,18-19$ & Alusão \\
\hline Dt 4,12 & Visão da forma de Deus & Jo 5,37 & Alusão \\
\hline Dt 4,24 & Fogo devorador & $\mathrm{Hb} 12,21$ & Alusão \\
\hline Dt 4,29 & Procurareis e não encontrareis & Jo 7,33-36 & Alusão \\
\hline Dt 4,32 & O dia da criação & Mc 13,19 & Alusão \\
\hline Dt 4,35 & Unidade do mandamento & Mc 12,31 & Citação \\
\hline Dt 5,9 & Punição dos pecados dos pais nos filhos & Jo 9,1-4 & Alusão \\
\hline Dt $5,16-21$ & Mandamentos & $\begin{array}{l}\text { Mc } 10,19 \\
\text { Mt } 19,18-19 \\
\text { Lc } 18,20 \\
\text { Rm } 13,8-10\end{array}$ & $\begin{array}{l}\text { Citação } \\
\text { Citação } \\
\text { Citação } \\
\text { Citação }\end{array}$ \\
\hline Dt 5,16 & Honrar pai e mãe & $\begin{array}{l}\text { Mc } 7,10 \\
\text { Mt } 15,4\end{array}$ & $\begin{array}{l}\text { Citação } \\
\text { Citação }\end{array}$ \\
\hline Dt 5,17 & Não matarás & Mt 5,21 & Citação \\
\hline Dt 5,18 & Não cometerás adultério & Mt 5,27 & Citação \\
\hline Dt 5,21 & Não cobiçarás & $\mathrm{Rm} 7,7$ & Citação \\
\hline Dt 6,4-5 & Ouve Israel! & $\begin{array}{l}\text { Mc } 12,29-33 \\
\text { Mt } 22,37 \\
\text { Lc } 10,27 \\
1 \text { Cor } 7,32-35\end{array}$ & $\begin{array}{l}\text { Citação } \\
\text { Citação } \\
\text { Citação } \\
\text { Citação }\end{array}$ \\
\hline Dt 6,4 & YHWH é único & Jo 8,54 & Alusão \\
\hline Dt 6,5 & Amar a Deus & Mt 22,37 & Citação \\
\hline Dt 6,13 & Adorar a Deus & $\begin{array}{l}\text { Mt 4,10 } \\
\text { Lc } 4,8\end{array}$ & $\begin{array}{l}\text { Citação } \\
\text { Citação }\end{array}$ \\
\hline Dt 6,16 & Não tentarás a Deus & $\begin{array}{l}\text { Mt 4,7 } \\
\text { Lc 4,12 }\end{array}$ & $\begin{array}{l}\text { Citação } \\
\text { Citação }\end{array}$ \\
\hline Dt 7,2 & Odiar o inimigo & Mt 5,43 & Alusão \\
\hline Dt 8,3 & Não só de pão & $\begin{array}{l}\text { Mt } 4,4 \\
\text { Lc } 4,4\end{array}$ & $\begin{array}{l}\text { Citação } \\
\text { Citação }\end{array}$ \\
\hline Dt 9,3 & Fogo devorador & $\mathrm{Hb} 12,29$ & Alusão \\
\hline Dt 9,4 & Justiça e graça & $\mathrm{Rm} 10,6-10$ & Alusão \\
\hline
\end{tabular}

${ }^{407}$ PAGANINI, S. Deuteronomio. p. 61-66. 


\begin{tabular}{|c|c|c|c|}
\hline Dt 9,19 & Teofania & $\mathrm{Hb} 12,21$ & Alusão \\
\hline Dt 10,17 & Imparcialidade divina & Gl 2,6 & Alusão \\
\hline Dt 10,17 & Deus dos deuses & $\begin{array}{l}\text { Ap } 17,14 \\
\text { Ap } 19,16\end{array}$ & $\begin{array}{l}\text { Citação } \\
\text { Citação }\end{array}$ \\
\hline Dt 11,6 & Abrir a boca e engolir & Ap 12,16 & Alusão \\
\hline Dt 13,1 & Fórmula do cânon & Ap 21,17-18 & Alusão \\
\hline Dt $13,12-16$ & Maldições dos inimigos & Gl $1,8-9$ & Alusão \\
\hline Dt 15,11 & Sempre tereis pobres convosco & Mc 14,7 & Alusão \\
\hline Dt 15,14 & Ofertar segundo as bênçãos & 1 Cor 16,2 & Alusão \\
\hline Dt 17,6 & Testemunhas & Jo 5,31-34 & Alusão \\
\hline Dt 17,7 & Expulsão da comunidade & 1 Cor 5,13 & Citação \\
\hline Dt $18,15-20$ & Um profeta como Moisés & At 3,22 & Alusão \\
\hline Dt 18,15 & Um profeta como Moisés & $\begin{array}{l}\text { Mc } 9,4-7 \\
\text { Mt } 17,5\end{array}$ & $\begin{array}{l}\text { Alusão } \\
\text { Citação }\end{array}$ \\
\hline Dt 19,15 & Duas ou três testemunhas & $\begin{array}{l}\text { Jo } 8,16-17 \\
2 \text { Cor } 13,1 \\
1 \text { Tm } 5,19\end{array}$ & $\begin{array}{l}\text { Alusão } \\
\text { Citação } \\
\text { Citação } \\
\text { Alusão }\end{array}$ \\
\hline Dt $19,16-20$ & A presença do Senhor & 1 Cor 5,4 & Citação \\
\hline Dt 19,21 & Lei do talião & Mt 5,38 & Citação \\
\hline Dt 20,3 & Não ter medo & $\mathrm{Hb} 12,3$ & Alusão \\
\hline Dt 21,23 & Todo aquele que é suspenso é maldito & Gl 3,13 & Citação \\
\hline Dt 23,1 & Proibição do incesto & 1 Cor 5,11 & Alusão \\
\hline Dt 23,5 & Respeito do sábado & Mc 2,23 & Alusão \\
\hline Dt 23,3-6 & Respeito aos votos & Mt 5,43 & Alusão \\
\hline Dt 24,1-4 & Regras matrimoniais & 1 Cor $7,39-40$ & Alusão \\
\hline Dt $24,1-3$ & Divórcio & $\begin{array}{l}\text { Mc } 10,4 \\
\text { Mt } 5,31 \\
\text { Mt } 19,7\end{array}$ & $\begin{array}{l}\text { Alusão } \\
\text { Alusão } \\
\text { Alusão }\end{array}$ \\
\hline Dt 24,14 & Respeito ao povo pobre & Mc 10,19 & Alusão \\
\hline Dt 25,4 & Arado de boi & 1 Cor 9,9 & Citação \\
\hline Dt 25,5 & Lei do levirato & $\begin{array}{l}\text { Mc } 12,19 \\
\text { Lc } 20,29-32\end{array}$ & $\begin{array}{l}\text { Alusão } \\
\text { Alusão }\end{array}$ \\
\hline Dt 27,20 & Incesto & 1 Cor $5,1-3$ & Alusão \\
\hline Dt 27,26 & Maldições para aqueles que estão sob a Lei & Gl 3,10 & Citação \\
\hline Dt 28,35 & Punição pela idolatria & Ap 16,2 & Citação \\
\hline Dt 29,3 & Olhos que não veem & $\operatorname{Rm~} 11,8$ & Citação \\
\hline Dt 29,17 & Raízes amargas & $\mathrm{Hb} 12,15$ & Citação \\
\hline Dt 29,19-20 & O livro da Lei & Ap 22,18-19 & Alusão \\
\hline Dt 30,4 & Retorno do exílio & Mc 13,27 & Citação \\
\hline
\end{tabular}




\begin{tabular}{|c|c|c|c|}
\hline Dt 30,11-14 & Justiça e graça & $\operatorname{Rm} 10,6-10$ & Alusão \\
\hline Dt $31,6.7 .13$ & Sê forte e corajoso! & $\begin{array}{l}1 \text { Cor } 16,13-23 \\
\mathrm{Hb} 13,5\end{array}$ & $\begin{array}{l}\text { Alusão } \\
\text { Citação }\end{array}$ \\
\hline Dt 32 & Cântico de Moisés & 1 Cor 10 & Alusão \\
\hline Dt 32,4 & Deus fiel e santo & $\begin{array}{l}\text { Ap 15,3 } \\
\text { Ap 16,5 } \\
\end{array}$ & $\begin{array}{l}\text { Citação } \\
\text { Citação }\end{array}$ \\
\hline Dt 32,21 & Provocar o Senhor & 1 Cor 10,22 & Citação \\
\hline Dt $32,35-36$ & Vingança & $\mathrm{Hb} 10,30$ & Alusão \\
\hline Dt 32,35 & A vingança é minha & $\mathrm{Rm} 12,19$ & Citação \\
\hline Dt 32,39 & É Deus quem dá e tira a vida & Jo 5,21 & Citação \\
\hline Dt 32,40 & Juramento com a mão levantada & Ap 10,5-6 & Citação \\
\hline Dt 32,43 & $\begin{array}{l}\text { Regozige-se, ó céus! } \\
\text { Anjos, adorem }\end{array}$ & $\begin{array}{l}\text { Rm } 15,10 \\
\text { Ap } 6,10 ; 19,2 \\
\text { Hb } 1,6\end{array}$ & $\begin{array}{l}\text { Citação } \\
\text { Citação } \\
\text { Citação }\end{array}$ \\
\hline Dt 34,10 & Conheceu Deus face a face & 1 Cor 13,12 & Alusão \\
\hline
\end{tabular}




\section{Referências Bibliográficas}

ALONSO-SCHÖKEL, L. אִֶּ In: Dicionário Bíblico Hebraico-Português. São Paulo: Paulus, 2014, p. 82-84.

ALONSO-SCHÖKEL, L. ’়ִ̣. In: Dicionário Bíblico Hebraico-Português. São Paulo: Paulus, 2014, p. 106-107.

ALONSO-SCHÖKEL, L. חיים In: Dicionário Bíblico Hebraico-Português. São Paulo: Paulus, 2014, p. 215-216.

ALONSO-SCHÖKEL, L. לִֵַ̣ In: Dicionário Bíblico Hebraico-Português. São Paulo: Paulus, 2014, p. 391-393.

ALTER, R. L'arte dela narrativa bíblica. Queriniana: Brescia, 1990.

ANDRADE, C. Geografia Bíblica. Rio de Janeiro: CPAD, 2018.

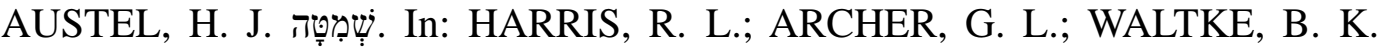
Dicionário Internacional de Teologia do Antigo Testamento. São Paulo: Vida Nova, 1998, p.1581-1582.

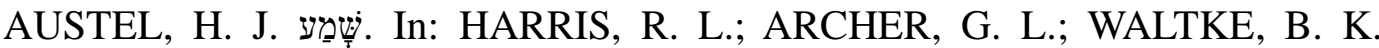
Dicionário Internacional de Teologia do Antigo Testamento. São Paulo: Vida Nova, 1998, p.1585-1587.

AZCÁRATE, J. L. L. Deuteronomio: Comentarios a la Nueva Biblia de Jerusalén. España: Editorial Desclée De Brouwer, 2009.

BAKER, D. W.; ARNOLD, B. T. Faces do Antigo Testamento: Um Exame das Pesquisas mais Recentes. Rio de Janeiro: CPAD, 2017.

BALANCIN, E. M. História do Povo de Deus. São Paulo: Paulus, 2005.

BARTON, J.; MUDDIMAN, J. The Oxford Commentary. Oxford University Press Bible, 2001.

BENTHO, E. C.; PLÁCIDO, R. L. Introdução ao Estudo do Antigo Testamento. Rio de Janeiro: CPAD, 2019.

BÍBLIA. A.T. Grego. Septuaginta. 1965; RAHLFS, A. Septuaginta: id est Vetus Testamentum

BÍBLIA HEBRAICA STUTTGARTENSIA. ELLIGER, K., RUDOLPH, W. (Eds.). Stuttgart: Deutsche Bibelgesellschaft, 1997.

BÍBLIA. A.T. Latim. FISCHER, B.; WEBWE, R. Biblia Sacra: iuxta vulgatam versionem. Editionem quintam emendatam retractatam praeparavit Roger Gryson. Stuttgart: Bibelgesellschaft; São Paulo: Sociedade Bíblica do Brasil, 2007.

BÍBLIA. A.T. Siríaco. Leiden Peshitta. Leiden: Peshita Institute Leiden, 2008.

BÍBLIA de Estudo Palavras-chave Hebraico e Grego. Rio de Janeiro: CPAD, 2015.

BÍBLIA de Jerusalém. Nova ed. ver. e ampl. 2. Impr. São Paulo: Paulus, 2003. 
BÍBLIA HEBRAICA quinta editione cum apparatu critico novis cu curis elaborato. אלה הדברים Deuteronomy (preparaed by Carmel McCarthy). Stuttgart: Deutsche Bibelgesellschaft, 2007.

BLENKINSOPP, J. Deuteronômio In: BROWN, R. E.; FITZMYER, J. A.; MURPHY, R. E. (Eds). Novo Comentário Bíblico São Jerônimo Antigo Testamento. São Paulo: Academia cristã; São Paulo: Paulus, 2013, p. 223-252.

BORN, V. D. Tabernáculo. In: BORN, V. D. Dicionário Enciclopédico da Bíblia. Petrópolis: Vozes; São Paulo: Paulus / Paulinas / Edições Loyola / Academia Cristã, 1977, c. 1463.

BORN, V. D. Tenda. In: BORN, V. D. Dicionário Enciclopédico da Bíblia. Petrópolis: Vozes; São Paulo: Paulus / Paulinas / Edições Loyola / Academia Cristã, 1977, c. 1485.

BOWLING, A. ירא. In: HARRIS, R. L.; ARCHER, G. L.; WALTKE, B. K. Dicionário Internacional de Teologia do Antigo Testamento. São Paulo: Vida Nova, 1998, p. 654-657.

BRENSINGER, T. L. חיה. In: VANGEMEREN, W. A. (org.) Novo dicionário internacional de teologia e exegese do Antigo Testamento. São Paulo: Cultura Cristã, 2011, v. 2, p. 106-110.

BRIGGS, R. S.; LOHR, J. N. Introdução Teológica ao Pentateuco: Uma análise da Torá como Escritura Sagrada. Rio de Janeiro: Acadêmico, 2013.

BROWN, R. Entendendo o Antigo Testamento: esboço, mensagem e aplicação de cada livro. São Paulo: Shedd Publicações, 2004.

BRUEGGEMANN, W. Deuteronomy. (Abingdon Old Testament commentaries) Includes bibliographical references and index. ISBN 0-687-08471-7 (alk. Paper), 2001.

BRUEGgEMANN, W. Teologia do Antigo Testamento: Testemunho, disputa e defesa. Santo André (SP): Academia crista; São Paulo: Paulus, 2014.

BUNIN, I. M. A Ética do Sinai: Ensinamentos dos sábios do Talmut. São Paulo: Editora Sêfer, 2019.

BUSHELL, M. S. Bible Works for Windows. Version 10. Norfolk, Va, Bible Works, LLC, 2015.

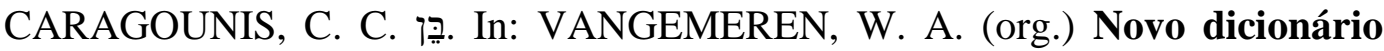
internacional de teologia e exegese do Antigo Testamento. São Paulo: Cultura Cristã, 2011, v. 1, p. 649-655.

CHAMPLIN, R. N. O Antigo Testamento Interpretado: Versículo por versículo: Deuteronômio. Vol. 2. São Paulo: Hagnos, 2018.

CHAVEZ, M. Diccionario de Hebreo Biblico. España: Editorial Mundo Hispano, 1997.

COLEMAN, W. L. Manual dos Tempos e Costumes Bíblicos. LINS, M. T. (Trad.). Curitiba, PR: Editora Betânia, 2017.

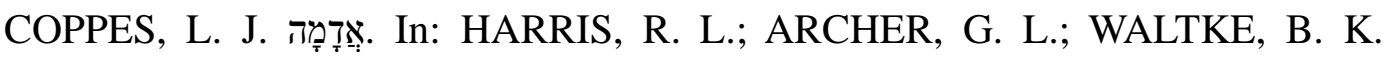
Dicionário Internacional de Teologia do Antigo Testamento. São Paulo: Vida Nova, 1998, p.13-15. 
CRAIGIE, P. C. Comentários do Antigo Testamento - Deuteronômio. São Paulo: Cultura Cristã, 2013.

CRÜSEMANN, F. A Torá. Petropólis: Vozes, 2002.

DAVIDSON, B. Léxico Analítico Hebraico e Caldaico. São Paulo: Edições Vida nova, 2018.

DE VAUX, R. Instituições de Israel no Antigo Testamento. São Paulo: Vida Nova, 2008.

DI SANTE, C. Liturgia judaica: Fontes, estrutura, orações e festas. São Paulo: Paulus, 2012.

DOCKERY, D. S. Manual bíblico vida nova. São Paulo: Vida Nova, 2001.

DOMERIS, W. R. \כָּ. In: VANGEMEREN, W. A. (org.) Novo dicionário internacional de teologia e exegese do Antigo Testamento. São Paulo: Cultura Cristã, 2011, v. 2, p. 656-657.

ECHEGARAY, J. G. al et. A Bíblia e seu Contexto. São Paulo: Ave Maria, 1994.

FABRIS, R. (Org.) Problemas e Perspectivas das Ciências Bíblicas. São Paulo: Loyola, 1993.

FAST, H. Moisés, Príncipe do Egito. Belo Horizonte: Itatiaia, 1960.

FEE, G.; STUART, D. Como Ler a Bíblia Livro por Livro: Um Guia Confiável para Ler e Entender as Escrituras Sagradas. Rio de Janeiro: Thomas Nelson Brasil, 2019.

FERNANDES, L. A.; GRENZER, M. Êxodo 15,22-18,27. São Paulo: Paulinas, 2011.

FERNANDES, L. A. Teologia, Antropologia e Ecologia em Gn 1,1-2,4a. Atualidade Teológica, v. 15, n. 37, p. 27-46, jan/abr, 2011.

FERNANDES, L. A.; GRENZER, M. Dança, Ó Terra: Interpretando Salmos. São Paulo: Paulinas, 2013.

FERNANDES, L. A. Análise do Salmo 110 e releitura no Novo Testamento, In: Revista Caminhos. V. 13, n. 2, jul./dez, 2015, p. 270-288.

FERNANDES, L. A. O êxodo da casa do sogro é prenúncio do êxodo do país opressor (Ex 4,19-23). Revista de Cultura Teológica, Ano XXIV, nº 87, Jan/Jun, 2016, p. 133-134.

FERNANDES, L. A.; BATTISTA, G.; ALVAREZ, G. A. B. Bíblia e Catequese: Fé em diálogo pela educação e pela paz. Rio de Janeiro: Editora PUC Rio; Rio de Janeiro: Letra Capital, 2017.

FERNANDES, L. A. Reflexão sobre o contexto e a singularidade de Dt 30,1114. Revista de Cultura Religiosa, Ano XXVIII - nº 97 - Set/Dez, 2020, 114 [95108]).

FERNANDES, L. A. Vida de Oração à luz da Palavra de Deus. Parte 1 janeiro a junho. Rio de Janeiro: Letra Capital, 2020.

FERNANDES, L. A. Análise retórica de Dt 30,11-14. Franciscanum 176, vol. 63 (2021): 1-19. 
FINKELSTEI, I.; SILBERMAN, N. A. La Biblia Desenterrada: Una nueva visión arqueológica del antiguo Israel y de los orígenes de sus textos sagrados. España: Siglo Veintiuno de España editores, 2003.

FISHER, M. C. נִתָן. In: HARRIS, R. L.; ARCHER, G. L.; WALTKE, B. K. Dicionário Internacional de Teologia do Antigo Testamento. São Paulo: Vida Nova, 1998, p.1017-1019.

FISCHER, A. A. O texto do Antigo Testamento. Barueri (SP): Sociedade Bíblica do Brasil, 2013.

FITZMYER, J. A. A interpretação da Escritura. Em defesa do método histórico-crítico. São Paulo: Loyola, 2011.

FRANCISCO. E. F. Manual da Bíblia Hebraica: Introdução ao Texto Massorético: Guia Introdutório para a Bíblia Hebraica Stuttgartensia. São Paulo: Vida Nova, 2008.

FRANCISCO. E. F. Antigo Testamento Interlinear Hebraico-Português. vol. 1. Pentateuco. Barueri (SP): Sociedade Bíblica do Brasil, 2012.

FREITAS, T. Análise exegética de Nm 18,1-7: funções e serviços dos sacerdotes e levitas. Rio de Janeiro, 2019. 136p. Dissertação. Departamento de Teologia. Pontifícia Universidade Católica do Rio de Janeiro.

FRIZZO, A. C. A Trilogia Social: o estrangeiro, o órfão e a viúva no Deuteronômio e sua recepção na Mishná. São Paulo: Edições Fons Sapientiae, 2020.

FREUD, S. O homem Moisés e a religião monoteísta. Porto Alegre (RS): L\&PM, 2020.

GalVaGnO, G.; GIUNTOLI, F. Pentateuco. Petrópolis: Vozes, 2020.

GARDNER, P. Quem é quem na Bíblia Sagrada. São Paulo: Editora Vida, 2020.

GESENIUS, H. F. W.; KAUTZSCH, E.; COWLEY, A. E. Gesenius' Hebrew Grammar. Oxford: Claredon press, 1910.

GOTTWALD, N. K. Introdução Socioliterária à Bíblia Hebraica. São Paulo: Paulus, 2011.

GRADL, F.; STENDEBACH, F. J. Israel e seu Deus: Guia de leitura para o Antigo Testamento. São Paulo: Loyola, 2001.

GRILLI, M.; PEREGO, G.; SERAFINI, F. Deuteronomio: Introduzione, traduzione e comento. Nuova Versione Della Bibbia Dai Testiantichi. Cnisello Balsamo (Milano): San Paolo, 2011.

GRISANTI, M. A. אְִָָ. In: VANGEMEREN, W. A. (org.) Novo dicionário internacional de teologia e exegese do Antigo Testamento. São Paulo: Cultura Cristã, 2011, v. 1, p. 262-267.

GUNNEWEG, A. H. Hermenêutica do Antigo Testamento. São Leopoldo (RS): Sinodal. 2003.

GUSSO, A. R. O Pentateuco: Introdução Fundamental e Auxílios para a Interpretação. Curitiba: A. D. Santos Editora, 2017. 
HABERSHON, A. R. Manual de Tipologia Bíblica: como conhecer e interpretar símbolos, tipos e alegorias das Escrituras Sagradas. CHOWN, G. São Paulo: Editora Vida, 2018.

HAGUE, S. T. תרֶָת. In: VANGEMEREN, W. A. (org.) Novo dicionário internacional de teologia e exegese do Antigo Testamento. São Paulo: Cultura Cristã, 2011, v. 4, p. 267-270.

HAYS, J. D.; DUVALL, J. S. Manual Bíblico Ilustrado Vida. São Paulo: Editora Vida, 2018.

HAMILTON, V. P. Manual do Pentateuco. Rio de Janeiro: CPAD, 2019.

HARRIS, R. L. כָּבב. In: HARRIS, R. L.; ARCHER, G. L.; WALTKE, B. K. Dicionário Internacional de Teologia do Antigo Testamento. São Paulo: Vida Nova, 1998, p.754-756.

HARRINGTON, W. J. Chave para a Bíblia: A revelação, a promessa, a realização. São Paulo: Paulus, 2014.

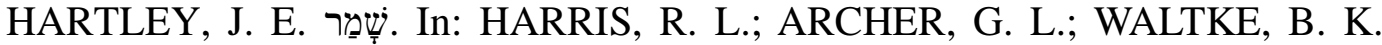
Dicionário Internacional de Teologia do Antigo Testamento. São Paulo: Vida Nova, 1998, p.1587-1590.

HASEL, G. F. Teologia do Antigo e Novo Testamento: Questões básicas no debate atual. São Paulo: Academia Cristã Ltda, 2015.

HENRY, M. Comentário Bíblico Antigo Testamento: Gênesis a Deuteronômio. Rio de Janeiro: CPAD, 2018.

HOFF, P. O Pentateuco. São Paulo: Editora Vida, 2007.

HOLladAY, W. L. Léxico Hebraico e Aramaico do Antigo Testamento. São Paulo: Vida Nova, 2010.

ILDEFONSO, E. Panorama do Antigo Testamento: Deuteronômio. Covington Theological Seminary, 1959.

JENNI, E.; WESTERMANN, C. Theological Lexicon of the Old Testament. Translated by BIDDLE, M. E. [s.n.], 1975.

JENSON, P. פּהן. In: VANGEMEREN, W. A. (org.) Novo dicionário internacional de teologia e exegese do Antigo Testamento. São Paulo: Cultura Cristã, 2011, v. 2, p. 599-604.

JOHANSSON, C.; HELlSTRÖM, I. Síntese Bíblica do Antigo Testamento: Pentateuco. Rio de Janeiro: CPAD, 2013.

JOSEFO. F. História dos Hebreus. Rio de Janeiro: CPAD, 2019.

JOÜON, P.; MURAOKA, T. Gramática Del Hebreo Bíblico. Navarra: Editorial Verbo Divino, 2003.

KAISER, W. C. נְשָׁ. In: HARRIS, R. L.; ARCHER, G. L.; WALTKE, B. K. Dicionário Internacional de Teologia do Antigo Testamento. São Paulo: Vida Nova, 1998, p. 1003-1007.

KAISER, W. C. ללָמדז. In: HARRIS, R. L.; ARCHER, G. L.; WALTKE, B. K. Dicionário Internacional de Teologia do Antigo Testamento. São Paulo: Vida Nova, 1998, p. 790-791. 
KESSLER, R. História Social do Antigo Israel. São Paulo: Paulinas, 2010.

KOVADLOFF, S. O irremediável Moisés e o espírito trágico do judaísmo. Rio de Janeiro: Editora José Olympio, 2005.

LAMBDIN. T. O. Introducción al Hebreo Bíblico. Estella (Navarra), 2001.

LAMADRID, A. G. al. et. História, Narrativa, Apocalíptica. São Paulo: Editora Ave Maria, 2011.

LASOR, W. S.; HUBBARD, D. A.; BUSH, F. W. Introdução ao Antigo Testamento. São Paulo: Vida Nova, 1999.

LAWRENCE, P. Atlas Histórico e Geográfico da Bíblia. Barueri, SP: Sociedade Bíblica do Brasil, 2008.

LAWRENCE, R. O. Guia do Leitor da Bíblia: Uma análise de Gênesis a Apocalipse capítulo por capítulo. Rio de Janeiro: CPAD, 2018.

LEWIS, J. P. אָרוֹן In: HARRIS, R. L.; ARCHER, G. L.; WALTKE, B. K. Dicionário Internacional de Teologia do Antigo Testamento. São Paulo: Vida Nova, 1998, p. 123-124.

LIMA, M. L. C. Exegese Bíblica: Teoria e Prática. São Paulo: Paulinas, 2014.

LIMA, M. L. C. A Palavra de Deus em palavras humanas: Para ler e compreender a Escritura. São Paulo: Paulinas, 2020.

LINDSAY, G. Moisés o libertador. Rio de Janeiro: Graça, 2002.

LINDSAY, G. Moisés o legislador. Rio de Janeiro: Graça, 2002.

LINDSAY, G. Moisés e a igreja no deserto. Rio de Janeiro: Graça, 2003.

LIVINGSTON, G. H. al et. Comentário Bíblico Beacon. Rio de Janeiro: CPAD, 2019.

LÓPEZ, F. G. El Deuteronomio: uma ley predicada. Estella/Navarra: Verbo Divino, 1989.

LÓPEZ, F. G. O Pentateuco: Introdução à leitura dos cinco primeiros livros da Bíblia. São Paulo: Editora Ave-Maria, 2014.

LUND. E.; NELSON, P. C. Hermenêutica: Princípios de Interpretação das Sagradas Escrituras. São Paulo: Editora Vida, 1968.

LUZA, N. Uma Introdução ao Pentateuco. São Paulo: Paulus, 2019.

MACARTHUR, J. Comentário Bíblico MacArthur: desvendando a verdade de Deus, versículo a versículo. Rio de Janeiro: Thomas Nelson Brasil, 2019.

MACDONALD, W. Comentário Bíblico del Antiguo Testamento: Deuteronomio. España: Editorial CLIE, 2004.

MANLEY, G. T. Novo Comentário da Bíblia: Deuteronômio. DAVIDSON, F. (org.). São Paulo: Vida Nova, 1997.

MANNUCCI, V. Bíblia, palavra de Deus: Curso de Introdução à Sagrada Escritura. São Paulo: Paulus, 2008.

MCCARTHY, C. Deuteronomy: Critical Apparatus and Notes (quinta editione), Vol. 5, Stuttgart: Deutsche Bibelgesellschaft, 2007. 
MCCARTHY, M. S. Per uma Teologia del Pacto nell'AT. Marietti: Turim, 1975.

MCCOMISKEY, T. E. עָשָׁ. In: HARRIS, R. L.; ARCHER, G. L.; WALTKE, B. K. Dicionário Internacional de Teologia do Antigo Testamento. São Paulo: Vida Nova, 1998, p. 1179-1181.

MCCONVILLE, J. G. Deuteronomy. Dowers Grove: InterVasity, 2002.

McKENZIE, J. L. Coração. In: Dicionário Bíblico. São Paulo: Paulus, 1984, p. 183-184.

McKENZIE, J. L. Deuteronômio. In: Dicionário Bíblico. São Paulo: Paulus, 1984, p. 232-234.

McKENZIE, J. L. Filho. In: Dicionário Bíblico. São Paulo: Paulus, 1984, p. 349350 .

McKENZIE, J. L. Nome. In: Dicionário Bíblico. São Paulo: Paulus, 1984, p. 658660.

McKenZIE, J. L. Páscoa. In: Dicionário Bíblico. São Paulo: Paulus, 1984, p. 696.

McKENZIE, J. L. Sábado. In: Dicionário Bíblico. São Paulo: Paulus, 1984, p. 809-811.

McKENZIE, J. L. Sabático, ano. In: Dicionário Bíblico. São Paulo: Paulus, 1984, p. 811-812.

McKENZIE, J. L. Sacerdote. In: Dicionário Bíblico. São Paulo: Paulus, 1984, p. 816-819.

McKENZIE, J. L. Tenda. In: Dicionário Bíblico. São Paulo: Paulus, 1984, p. 918-921.

MCMURTRY, G. S. As Festas Judaicas do Antigo Testamento: Seu significado histórico, cristão e profético. Curitiba: A. D. Santos Editora, 2019.

MENEZES, V. M. Código Hamurabi e a Lei de Moisés. Itabaiana, SE: Amazon.com Clubedeautores.com.br, 2016.

MESSADIÉ, G. Moisés: Um Príncipe sem Coroa. Rio de Janeiro: Bertrand Brasil, 2014.

MESSADIÉ, G. Moisés: O Profeta Fundador. Rio de Janeiro: Bertrand Brasil, 2014.

MILlER, J. W. As Origens da Bíblia: Repensando a História Canônica. São Paulo: Loyola, 2004.

MILLER, S. M.; HUBER, R. V. A Bíblia e sua história: O surgimento e o impacto da Bíblia. Barueri, SP: Sociedade Bíblica do Brasil, 2013.

NAUDE, J. A. רָָָ. In: VANGEMEREN, W. A. (Org.). Novo dicionário internacional de teologia e exegese do Antigo Testamento. São Paulo: Cultura Cristã, 2011, v. 3, p. 1004-1012.

NICCACCI, A. Sintaxis del Hebreo Bíblico. Navarra: Editorial Verbo Divino, 2002. 
OSWALT, J. N. לכָּ In: HARRIS, R. L.; ARCHER, G. L.; WALTKE, B. K. Dicionário Internacional de Teologia do Antigo Testamento. São Paulo: Vida Nova, 1998, p. 722-724

OTTO, E. A Lei de Moisés. São Paulo: Loyola, 2011.

PAGANINI, S. Deuteronomio: nuova versione, introduzione e comento. Milano: Paoline Editoriale Libri, 2011.

PAGANELli, M. Introdução ao Estudo da Tipologia Bíblica. Santo André: Geográfica, 2018.

PAPOLA, G. Deuteronomio: Introduzione, traduzione e comento. Cinisello Balsamo/Milano: San Paolo, 2011.

PAYNE, J. B. פּהן. In: HARRIS, R. L.; ARCHER, G. L.; WALTKE, B. K. Dicionário Internacional de Teologia do Antigo Testamento. São Paulo: Vida Nova, 1998, p. 704-705.

PEREGO, G. Atlas Bíblico interdisciplinar: escritura, história, geografia, arqueologia, teologia: análise comparativa. Aparecida, SP: Editora Santuário; São Paulo: Paulus, 2008.

PURY, A. O Pentateuco em Questão: As origens e a composição dos cinco primeiros livros da Bíblia à luz das pesquisas recentes. Petropolis, RJ: Vozes, 2002.

RAD, G. V. Studies in Deuteronomy. SCM PRESS LTD 56 Bloomsbury Street London, 1961.

RAD, G. V. Teologia do Antigo Testamento. São Paulo: ASTE/TARGUMIM, 2006.

RAD, G. V. "The Form-Critical Problem of the Hexateuch", The Problem of the Hexateuch and Other Essays. Nova York: McGraw-Hill, 1966.

REINKE, A. D. Atlas Bíblico Ilustrado. São Paulo: Editora Hagnos, 2018.

REINKE, A. D. Os outros da Bíblia: História, fé e cultura dos povos antigos e sua atuação no plano divino. Rio de Janeiro: Thomas Nelson Brasil, 2019.

RENDTORFF, R. A “Fórmula da Aliança”. São Paulo: Loyola, 2004.

RENDTORFF, R. A formação do Antigo Testamento. São Leopoldo: Sinodal, 2016.

ROITMAN. A. D. Bíblia, Exegese e Religião: Uma leitura do judaísmo. São Paulo: Editora Vida, 2015.

RÖMER, T. A chamada história deuteronomista: introdução sociológica, histórica e literária. Petrópolis: Vozes, 2008.

ROSE, M. Deuteronômio. In: RÖMER, T.; MACCHI, J. D.; NIHAN, C. (org.). Antigo Testamento: história, escritura e teologia. São Paulo: Edições Loyola, 2010, p. 260-284.

RUSHANSKY, E. O Palco da História: As Raízes Judaicas e o Cristianismo. Jerusalém: T-Land Ltda, 2005. 
SÁNCHEZ, E. Comentário Bíblico Iberoamericano Deuteronomio. Texto de la Mueva Versión Internacional. Introducción y comentário. Buenos Aires: Ediciones Kairós, 2002.

SCHAAEFFER, F. A. Josué e a História Bíblica. São Paulo: Cultura Cristã, 2005.

SCHMID, K. História da Literatura do Antigo Testamento: Uma introdução. São Paulo: Loyola, 2013.

SCHMIDT, W. H. A fé do Antigo Testamento. São Leopoldo, RS: Sinodal, 2004.

SCHMIDT, W. H. Introdução ao Antigo Testamento. São Leopoldo, RS: Sinodal, 2013.

SESBOÜÉ, D.; LACAN, M. F. Festas. In: LEON-DUFOUR, X. Vocabulário de Teologia Bíblica. Petrópolis: Vozes, 2009, c. 350-351.

SICRE, J. L. Com os Pobres da Terra: A Justiça Social nos Profetas de Israel. São Paulo: Academia Cristã Ltda; São Paulo: Paulus, 2015.

SIMIAN-YOFRE, H. et. al. Metodologia do Antigo Testamento. São Paulo: Loyola, 2015.

SMITH, R. L. Teologia do Antigo Testamento: História, Método e Mensagem. São Paulo: Vida Nova, 2001.

SIQUEIRA, F. S. MI 1,6-14: A crítica profética ao culto do Segundo Templo e sua justificativa sob a aspecto teológico. Rio de Janeiro, 2013. 133p. Dissertação. Departamento de Teologia. Pontifícia Universidade Católica do Rio de Janeiro.

SIQUEIRA, F. S. MI 2,1-9 e 2,17-3,5: Crise do Sacerdócio e Escatologia no séc. V a.C. Rio de Janeiro, 2019. 280p. Tese. Departamento de Teologia. Pontifícia Universidade Católica do Rio de Janeiro.

SKA, J. L.; SONNET, J. P.; WÉNIN, A. Análisis narrativo de relatos del AntiguoTestamento: Introdução. Navarra: Verbo Divino, 2001.

SKA, J. L. "I nostri padri ci hanno raccontato". Introduzione all'analisi dei racconti dell'Antico Testamento. Bologna: EDB, 2012.

SKA, J. L. Introdução à Leitura do Pentateuco: chave para interpretação dos cinco primeiros livros da Bíblia. São Paulo: Loyola, 2014.

SKA, J. L. O Antigo Testamento: Explicado aos que conhecem pouco ou nada a respeito dele. São Paulo: Paulus, 2015.

SKA, J. L. O Canteiro do Pentateuco: Problemas de Composição e de Interpretação. Aspectos Literários e Teológicos. São Paulo: Paulinas, 2016.

SKA, J. L. Antigo Testamento: Introdução. Petrópolis: Vozes, 2018.

SKA, J. L. Antigo Testamento: Temas e Leituras. Petrópolis: Vozes, 2018.

STORNIOLO, I. Como Ler o Livro do Deuteronômio: Escolher a vida ou a morte. São Paulo: Paulus, 2004.

SWINDOLL, C. R. Moisés: Um homem dedicado e generoso. São Paulo: Mundo Cristão, 2017. 
THOMPSON, J. A. Deuteronômio Introdução e Comentário. São Paulo: Vida Nova, 2006.

TOGNINI, E. O Período Interbíblico: 400 anos de silêncio profético. São Paulo: Hagnos, 2009.

TOV, E. A Bíblia Grega \& Hebraica: Ensaios Reunidos Sobre a Septuaginta. FRANCISCO, E. F. (trad.). Rio de Janeiro: Bvbooks Editora, 2016.

TOV, E. Crítica Textual da Bíblia Hebraica. Rio de Janeiro: Bvbooks Editora, 2016.

YAMAUCHI, E. חיפים. In: HARRIS, R. L.; ARCHER, G. L.; WALTKE, B. K. Dicionário Internacional de Teologia do Antigo Testamento. São Paulo: Vida Nova, 1998, p. 450-458.

YAMAUCHI, E. חרֶב. In: HARRIS, R. L.; ARCHER, G. L.; WALTKE, B. K. Dicionário Internacional de Teologia do Antigo Testamento. São Paulo: Vida Nova, 1998, p. 523-526.

WAJDENBAUM, P. Argonautas do deserto. Análise estrutural da Bíblia Hebraica. São Paulo: [s. n.], 2015.

WALTON, J. H.; MATTHEWS, V. H.; CHAVALAS, M. W. Comentário histórico-cultural da Bíblia: Antigo Testamento. São Paulo: Vida Nova, 2018.

WALTKE, B. K.; O'CONNOR, M. P. Introdução à sintaxe do Hebraico Bíblico. São Paulo: Cultura Cristã, 2006.

WATTS, J. W. Reading Law: The Rhetorical Shaping of the Pentateuch. The Biblical Seminar 59. Sheffield: Sheffield Academic Press, 1999.

WEGNER, P. D. IR̦. In: VANGEMEREN, W. A. (org.) Novo dicionário internacional de teologia e exegese do Antigo Testamento. São Paulo: Cultura Cristã, 2011, v. 1, p. 1107-1109.

WÉNIN, A. O Homem Bíblico: Leituras do Primeiro Testamento. São Paulo: Edições Loyola, 2006.

WIERSBE, W. W. Comentário Bíblico Expositivo: Antigo Testamento volume I, Pentateuco. Santo André (SP): Geográfica Editora, 2006.

WILliAMS, T. F. צוה. In: VANGEMEREN, W. A. (org.) Novo dicionário internacional de teologia e exegese do Antigo Testamento. São Paulo: Cultura Cristã, 2011, v. 1, p. 772-776.

WILLI-PLEIN, I. Sacrifício e Culto no Israel do Antigo Testamento. São Paulo: Loyola, 2001.

WOODS. E. J. Tyndale Old Testamenty Commentaries: Deuteronomy: an introduction and commentary. vol. 5. IVP Academic. Evangelically Rooted. Critically Engaged, 2011.

WORK, T. Deuteronomy: Brazos Theological Commentary on the Bible. Quotations of Deuteronomy are adapted from the World English Bible, na adaptation of the American Standard Version in public domain (ebible.org/web), 2009.

WRIGHT, C. J. H. Deuteronomio. Roma: Edizioni GBU, 2009. 
VAN GRONINGEN, G. עָבָר In: HARRIS, R. L.; ARCHER, G. L.; WALTKE, B. K. Dicionário Internacional de Teologia do Antigo Testamento. São Paulo: Vida Nova, 1998, p. 1069-1074.

VINE, W. E.; al et. Viver. In: Dicionário Vine: O significado exegético e expositivo das palavras do Antigo e Novo Testamento. Rio de Janeiro: Thomas Nelson Brasil, 2016, p. 332-334.

VOGT, P. T. Interpretação do Pentateuco. São Paulo: Cultura Cristã, 2015.

ZABATIERO. J. Manual de Exegese. São Paulo: Garimpo Editorial, 2019.

ZENGER, E. et. al. Introdução ao Antigo Testamento. São Paulo: Edições Loyola, 2003.

ZUCK, R. B. Teologia do Antigo Testamento. Rio de Janeiro: CPAD, 2019. 